Virginia Novaes Procópio de Araujo

\title{
$O$ ato médico no crime de tortura
}

Dissertação de mestrado

Orientador: Prof. Dr. Roberto Augusto de Carvalho Campos

Universidade de São Paulo

Faculdade de Direito

São Paulo

2012 


\section{VIRGINIA NOVAES PROCÓPIO DE ARAUJO}

\section{O ATO MÉDICO NO CRIME DE TORTURA MESTRADO EM DIREITO}

Dissertação apresentada à Banca Examinadora da Faculdade de Direito da Universidade de São Paulo, como exigência para obtenção do título de Mestre em Direito, sob a orientação do Professor Doutor Roberto Augusto de Carvalho Campos. 


\section{FOLHA DE APROVAÇÃO}

Candidata: Virginia Novaes Procópio de Araujo

Natureza: Dissertação de Mestrado

Instituição: Faculdade de Direito da Universidade de São Paulo

Objetivo: Exigência para obtenção do título de Mestre em Direito

Orientador: Professor Doutor Roberto Augusto de Carvalho Campos

Concentração: Direito Penal

Data da Banca:

Prof. Dr. Roberto Augusto de Carvalho Campos (Orientador)

Professor:

Titulação:

Instituição: Universidade de São Paulo

Professor:

Titulação:

Instituição:

Professor:

Titulação:

Instituição: 


\section{DEDICATÓRIA}

Aos meus queridos pais, Heitor e Eliana, que me deram a vida e todas as oportunidades possiveis para eu atingir meus objetivos e sonhos.

Aos meus irmãos, Guilherme e Cristina, e a minha cunhada Mikele, que me ensinaram por meio de suas ações como eu devo agir no mundo e por serem amigos tão fiéis e verdadeiros.

Aos meus saudosos e queridos avós que sempre me trouxeram muitas alegrias: Bento Carlos, Zilda, Antonio Luiz e Beatriz (in memoriam). 


\section{AGRADECIMENTOS}

Agradeço ao Professor Doutor Roberto Augusto de Carvalho Campos por todos seus ensinamentos no universo prático do Biodireito, pela incrível oportunidade de atuar nessa área e, especialmente, pela chance de desenvolver o curso de pós-graduação stricto sensu em Direito pela Universidade de São Paulo.

Ao apoio dos Professores Doutor Alvino Augusto de Sá, Doutor Henrique Caivano Soares, Doutora Janaina Conceição Paschoal, Doutora Cláudia Perrone-Moisés e sua orientanda Renata Nagamine.

Aos advogados e funcionárias de Camargo \& Campos Advogados Associados, que antes e durante o desenvolvimento desta pesquisa sempre me acolheram com muito carinho: Dra. Rosmari Camargo, Dr. Ronaldo Rodrigues, Dr. Lucas Loesch, Dr. Emerson Silva, Dr. Jefferson Moreira, Dr. Marcos Crivoi e às queridas Marlene Balacci e Selma Moura.

Ao querido amigo Marcelo Momo por me ensinar muito sobre Direito Penal.

A minha melhor amiga, minha irmã Cristina.

Aos queridos amigos e amigas que tiveram sua contribuição por me ajudar na realização e conclusão deste trabalho: Luciana Botter, Estela Takahashi, Thais Burmeister, Sílvia Helena Mellim, Mariana Preturlan, Diana Castro, Lorena Vicini, Patricia Burmeister, Cecília Teixeira, Mayra Capelasso, Patricia Villati, Adriana Gregorut, Julia Carvalho, Vinícius Menezes, Flávia Lorenzon, Rafael Abdulmassih, Heloiza Nery, Guilherme Fernandes, Henrique Salguero, Marcus Vinícius Romão, Adryanna Toledo, Yuri Ferreira, Neury Freitas, Leonardo Gaboardi, Tatiana Mesquita Nunes, Fernanda Bublitz, Nicole Boh, Evelise Junqueira, Renata Pedroso, Camila Pavanelli, Isabel Botter, Cristina Momo, Conor Callanan e Mark Dudley.

Ao meu anjo da guarda e a todos os espíritos de luz que me guiaram ao longo deste sombrio assunto. 
[...] o passado é prólogo [...]

(William Shakespeare - A tempestade)

O maior mal do homem é poder, a todo o momento, reverter uma situação e, mesmo assim, não fazê-lo.

(Martin Buber) 


\section{RESUMO}

A presente pesquisa tem como objetivo verificar se a legislação pós Segunda Guerra Mundial foi apta a inibir o comportamento maleficente de médicos no auxílio em especializar, dissimular e acobertar a tortura. Nesse sentido, pretende-se demonstrar o envolvimento médico com experimentos em seres humanos durante a Segunda Guerra Mundial e corroborar que a maleficência médica, todavia, ainda nos dias de hoje é empregada na sociedade contemporânea, permitindo aos profissionais de saúde, desde o período da Guerra Fria, o envolvimento com a tortura e a consequente violação dos princípios da Bioética, especialmente, na conjuntura atualíssima da guerra norte-americana contra o terrorismo. Em um segundo momento, o intuito é propor soluções, caso se verifique que a legislação e os demais esforços se demonstrem contraproducentes, tendo em vista as noções de Bioética, as normas de Direito Internacional e os Direitos Humanos.

Palavras-chave: Bioética - tortura - maleficência - médicos - legislação - Direitos Humanos. 


\begin{abstract}
The present research aims to verify if legislation created after World War II was able to inhibit maleficent behavior from medical doctors in the improvement and cover-up of torture. This study aims to demonstrate the medical involvement in experiments with human beings during World War II and confirm that medical maleficence was and still is part of our reality, allowing doctors to involve with torture since the Cold War until current days, especially in the United States' war on terrorism, violating the basic principles of Bioethics. Secondly, if legislation and overall efforts prove to be inoperative and inefficient, the objective is to propose solutions, in light of notions of Bioethics, rules of International Law and Human Rights.
\end{abstract}

Key-words: Bioethics - torture - maleficence - medical doctors - legislation - Human Rights. 


\section{SUMÁRIO}

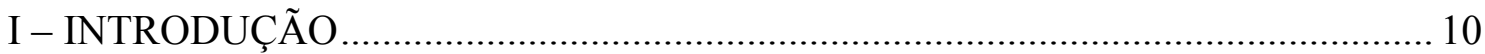

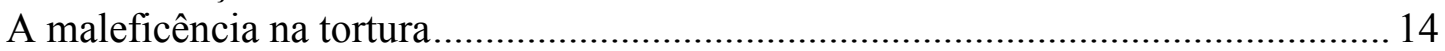

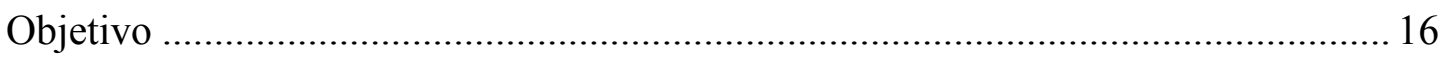

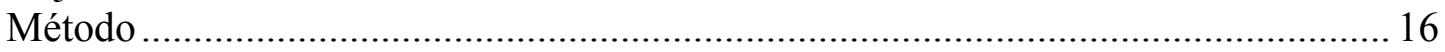

II - BIOÉTICA, BENEFICÊNCIA E NÃO MALEFICÊNCIA …............................... 18

III - O CRIME DE TORTURA E A EVOLUÇÃO DA NOÇÃO DE CRIMES

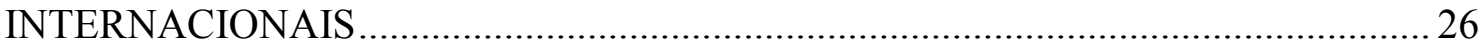

a) Diferença entre Direito Internacional Penal e Direito Penal Internacional ......... 26

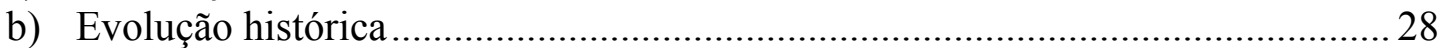

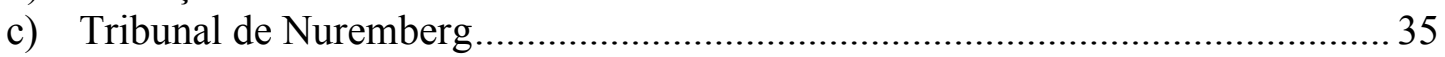

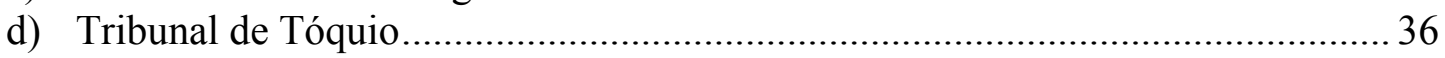

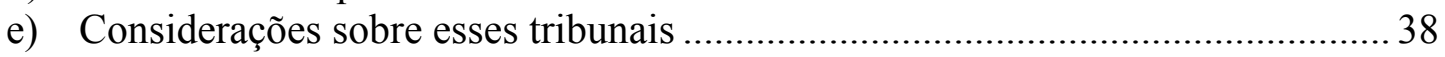

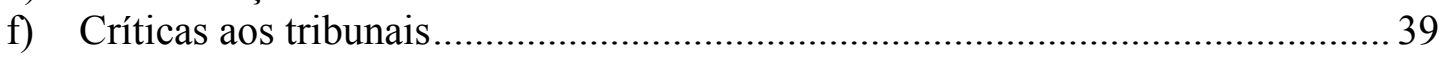

g) Consequências dos Tribunais de Exceção................................................................ 39

h) Da situação atual dos Tribunais Penais Internacionais...................................... 42

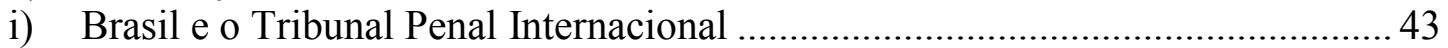

j) Tribunal Penal Internacional - Outras questões ............................................... 45

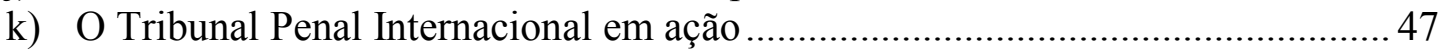

1) Desafios atuais do Tribunal Penal Internacional .................................................. 48

IV - MÉDICOS NAZISTAS E O SURGIMENTO DO CÓDIGO DE NUREMBERG 52

V - O ENVOLVIMENTO MÉDICO COM TORTURA NA ATUALIDADE .............69

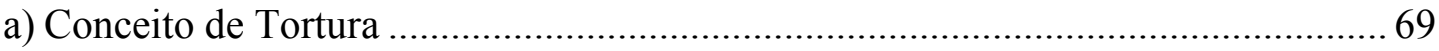

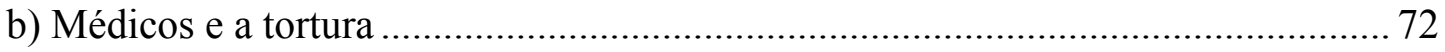

c) Especialização da tortura por meio da ajuda médica: a experiência americana ..... 86

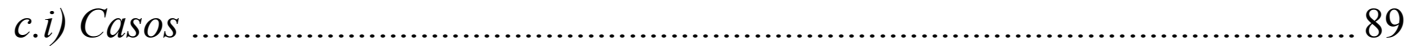

c.ii) Greve de fome e o cuidado com os presos .................................................... 97

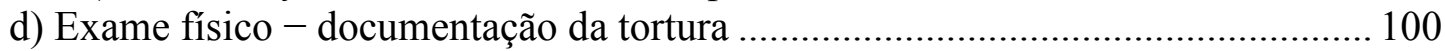

e) Possíveis explicações para o comportamento dos médicos ................................... 109

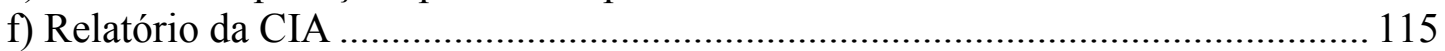

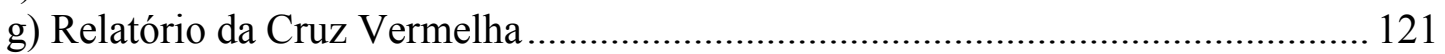

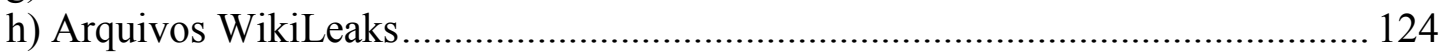

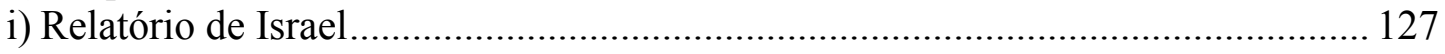

j) Medida de Segurança e formas atuais de participação do médico no sofrimento alheio

VI - CONCLUSÃO: POSSÍVEIS SOLUÇÕES ..................................................... 141

a) Sanções aos médicos, influência de organizações internacionais e amparo aos futuros

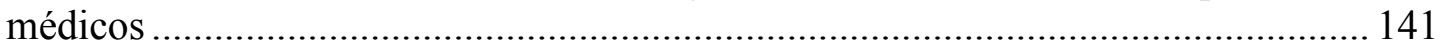

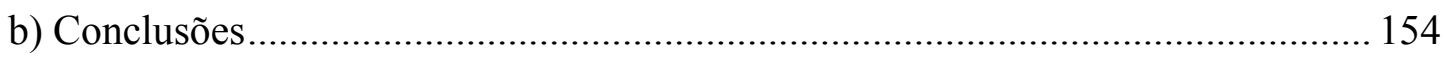

VII - REFERÊNCIAS BIBLIOGRÁFICAS ......................................................... 157 


\section{I - INTRODUÇÃO}

É tradição entre os estudantes que se graduam em Medicina declararem de modo solene obediência ao "Juramento de Hipócrates", texto histórico cuja autoria é atribuída ao próprio médico grego, considerado "o pai da Medicina". Esse texto, como já sabido por muitos, estabelece alguns preceitos fundamentais da ética médica, dentre os quais cita-se o seguinte: "Aplicarei os regimes para o bem do doente segundo o meu poder e entendimento, nunca para causar dano ou mal a alguém". ${ }^{1}$

No entanto, em um dos períodos históricos mais atrozes da humanidade, ou seja, durante a Segunda Guerra Mundial, foram realizadas inúmeras práticas contrárias a esse preceito básico. Um dos exemplos mais emblemáticos são as pesquisas médicas conduzidas nos campos de concentração. Somente em um momento posterior tais experimentos foram considerados crimes contra a humanidade.

Um caso notório de um médico que participou da tortura nazista foi o do Dr. Josef Mengele. Conhecido como o "anjo da morte", ele se utilizava dos presos de Auschwitz, especialmente gêmeos, para realizar seus experimentos. ${ }^{2}$ Entre as atrocidades figuram a tentativa de alterar a coloração da íris por meio de injeção de tinta nos olhos, a união de veias e a amputação de membros.

Além disso, os prisioneiros mais fortes eram selecionados e submetidos a sessões de tortura, que consistiam em imergi-los em tanques de água gelada, totalmente nus, durante madrugadas inteiras, com um termômetro no canal retal, para depois serem aquecidos rápida ou lentamente $\mathrm{e}$, assim, verificar a melhor maneira de aquecer um soldado em situações de hipotermia. ${ }^{3}$

Ao término da Segunda Guerra Mundial, em 1945, foi criado em Nuremberg, na Alemanha, um dos mais conhecidos Tribunais de Exceção da história: o Tribunal de Nuremberg, composto por uma Corte internacional para julgar os crimes cometidos pelos nazistas. Em um primeiro momento foram julgados os principais criminosos de guerra; em seguida, mais 12 casos foram levados a julgamento: os denominados casos subsequentes (subsequent trials). Dentre eles enquadravam-se os casos dos médicos, em que 23 médicos nazistas foram acusados de realizar experimentos desumanos em civis alemães e de outras

\footnotetext{
${ }^{1}$ Juramento de Hipócrates. Disponível em:

$<$ http://www.cremesp.org.br/?siteAcao=Historia\&esc=3>. Acesso em: 01 nov. 2009.

2 WEINDLING, P.J., Nazi Medicine and the Nuremberg Trials: from medical war crimes to informed consent, New York, Palgrave Mcmillan, 2004, p. 18.

${ }^{3}$ WEINDLING, P.J., op.cit., p. 94.
} 
nacionalidades. Dezesseis réus foram condenados, sete deles à pena de morte, e sete foram absolvidos. ${ }^{4}$

Esses julgamentos não se limitaram unicamente à condenação de nazistas, mas também resultaram na elaboração de preceitos éticos para a pesquisa clínica, conhecido como Código de Nuremberg, fato que marcou o início da noção de Bioética. O mundo percebeu que a ciência poderia ser usada como instrumento de banalização da crueldade, e, para impedir isso, eram necessários parâmetros éticos universais que pudessem ser aplicados aos seres humanos submetidos a pesquisas. A seguir, algumas orientações que foram estabelecidas por esse Código:

1. O consentimento consciente dos sujeitos das pesquisas é essencial.

2. A pesquisa deve ser baseada em experiências prévias com animais.

3. Os riscos devem ser justificados com base nos benefícios que se espera obter.

4. O sofrimento físico e mental deve ser evitado.

5. Pesquisas nas quais morte ou dano irreversível e incapacitante são esperados não devem ser realizadas. ${ }^{5}$

Percebe-se, da leitura desse Código, que já havia indícios de vedação de tratamento desumano por parte de médicos, apesar de a terminologia "tortura" ainda não ser empregada nesse momento. No entanto, essas diretrizes éticas não foram suficientes para evitar abusos como os realizados por médicos norte-americanos em pesquisas com prisioneiros negros sobre o tratamento da sífilis durante os anos 1960. Somente no ano de 1964, em Assembleia Geral, a Associação Médica Mundial (AMM), entidade reguladora de todas as associações médicas nacionais, instituiu a Declaração de Helsinki, que resultou na aceitação do Código de Nuremberg pelas entidades médicas de todo o mundo. ${ }^{6}$

Em 1966, a Assembleia Geral das Nações Unidas adotou o Pacto Internacional dos Direitos Civis e Políticos, que entrou em vigor em 1976 e determinou, em seu artigo $7^{\circ}$, que:

Artigo $7^{\circ}$ - Ninguém poderá ser submetido a tortura, nem a penas ou tratamentos cruéis, desumanos ou degradantes. Será proibido, sobretudo, submeter uma pessoa, sem seu livre consentimento, a experiências médicas ou científicas.

\footnotetext{
${ }^{4}$ CRETELla NETO, J., Curso de Direito Internacional Penal, Ijuí, Unijuí, 2008, p. 110.

${ }^{5}$ CRETELLA NETO, J., op.cit., p. 113.

${ }^{6}$ Site da Associação Médica Mundial. Disponível em:

<http://www.wma.net/en/20activities/10ethics/10helsinki/>. Acesso em: 8 fev. 2012.
} 
Isso significou que a tortura não era apenas uma prática moralmente condenável, mas um ato que viola os Direitos Humanos e que, portanto, os Estados não deveriam permiti-la.

Nesse contexto, cada país criou sua forma de reafirmar esses valores. Infelizmente, no Brasil, somente em 1988, com a promulgação da Constituição Federal, a questão da tortura foi abordada. Em conformidade à Carta Magna, o Código de Ética Médica Brasileiro de 1988 teve, pela primeira vez, um artigo que vedava ao médico a participação em tortura. O Novo Código de Ética Médica, aprovado pela Resolução no 1931/2009 do Conselho Federal de Medicina, também traz essa vedação, com uma nova redação. Ademais, o Brasil possui uma lei que define e criminaliza a tortura (Lei $n^{\circ}$ 9.455/1997). Na prática, porém, para alguns a tortura é ainda uma constante em território nacional. Conforme explica Tânia Kolker,

Os Institutos Médico-Legais, responsáveis pelos exames de corpo de delito, que poderiam comprovar os casos de torturas e execuções sumárias, permanecem vinculados à própria polícia e, com frequência, é o próprio torturador quem conduz o torturado para exame. Não se tem conhecimento de nenhum caso recente de participação de profissionais da saúde em sessões de tortura, mas, até hoje dificilmente os laudos de necropsias são conclusivos quanto às evidências de torturas e execuções extrajudiciais. Como consequência, essas ocorrências raramente resultam em inquérito administrativo ou ação judicial contra os responsáveis e permanecem inteiramente impunes. ${ }^{7}$

Desse modo, o papel dos médicos de atestar e denunciar a prática de tortura não é cumprido, tornando-se uma prática corriqueira devido ao medo, à omissão ou à cumplicidade do profissional que deveria combatê-la.

A Bioética ainda é uma ciência relativamente nova. Para Maria Helena Diniz, ${ }^{8}$ esta área do conhecimento seria um conjunto de reflexões filosóficas e morais sobre a vida em geral e sobre as práticas médicas em particular. Mas, para não se tornar vítima de anseios escusos de cada Estado, a Bioética precisa de um paradigma de referência antropológica e moral: o valor supremo da pessoa humana, de sua vida, dignidade e autonomia ou liberdade.

Desde o término da Segunda Guerra Mundial, a noção de Bioética está em constante evolução, mas sempre pautada por princípios norteadores dos médicos, a saber: o

\footnotetext{
${ }^{7}$ KOLKER, T., "Os profissionais da saúde e as torturas nas prisões", Revista Saúde e Direitos Humanos, Ministério da Saúde. Fundação Oswaldo Cruz, Núcleo de Estudos em Direitos Humanos e Saúde Helena Besserman. Ano 2, n. 2, Brasília, 2005, p. 19. Disponível em: $<$ http://www.ensp.fiocruz.br/comunicacao saudedh.cfm>. Acesso em: 02 nov. 2009.

8 O Estado Atual do Biodireito. Saraiva, São Paulo, 2002, p. 13.
} 
princípio da autonomia (o respeito à vontade do paciente, do qual decorre a noção de livre consentimento), o princípio da beneficência (o médico só pode usar o tratamento para o bem do paciente), o princípio da não maleficência (é obrigação do médico não acarretar dano intencional ao paciente) e o princípio da justiça (caracterizado pela imparcialidade na distribuição de riscos e benefícios). ${ }^{9}$

Assim, em um Estado Democrático de Direito, a Bioética está diretamente relacionada à noção de respeito à dignidade humana.

A proibição da tortura no Direito Internacional se destaca por ser absoluta e aplicável em todas as circunstâncias e ocasiões. Uma breve evolução desse conceito pode ser observada nos diversos instrumentos internacionais de ajuda humanitária: 0 art. $5^{\circ}$ da Declaração Universal dos Direitos Humanos de 1948, o Pacto Internacional dos Direitos Civis e Políticos (1966), a Convenção Europeia dos Direitos Humanos (1950), a Convenção Americana sobre Direitos Humanos (1978) e a Carta Africana dos Direitos Humanos e dos Povos (1981). Em 1984, a ONU adotou a Convenção Contra Tortura e Outros Tratamentos ou Punições Cruéis, Desumanos ou Degradantes, com atenção especial à proibição absoluta da tortura e à criação de normas adicionais para assistência na prevenção e investigação. ${ }^{10}$

Tais princípios passaram a gozar de significativo consenso e relativo respeito, especialmente após a dissolução de regimes totalitários no final do século XX. Os ataques terroristas de 11 de Setembro de 2001 e suas respectivas consequências reafirmaram esses princípios. Desse modo, a Ordem Mundial continua defendendo a vedação do uso de tortura, entretanto, na prática, se observa diversas violações, inclusive, com 0 envolvimento de médicos.

A guerra contra o terrorismo legitimou os Estados Unidos a empregarem a tortura, com o auxílio de médicos, conforme demonstrado amplamente pela imprensa internacional em Abu Ghraib e, mais recentemente, na participação de médicos-militares monitorando sessões de tortura em Guantánamo, prisão norte-americana localizada em Cuba. ${ }^{11}$

\footnotetext{
${ }^{9}$ NEVES, N.M.B.C.; SIQUEIRA, J.E., “A Bioética no atual Código de Ética Médica”. Revista Bioética, CFM, v. 18, n. 2, 2010, p. 442. Disponível em: $<$ http://revistabioetica.cfm.org.br/index.php/revista_bioetica/article/view/575/547> . Acesso em: 8 fev. 2012. ${ }^{10}$ IKAWA, D.R., "Convenção contra a tortura e outros tratamentos ou penas cruéis, desumanos ou degradantes (1984)". In: ALMEIDA, Guilherme A. de; PERRONE-MOISÉS, Cláudia (Coords.), Direito Internacional dos Direitos Humanos: Instrumentos Básicos, $2^{a}$ ed. São Paulo, Atlas, 2007, p. 51.

${ }^{11}$ Site do O Estado de São Paulo. Disponível em: $<$ http://www.estadao.com.br/noticias/internacional,insetoseram-usados-durante-torturas-em-guantanamo,356331,0.htm >. Acesso em: 08 fev. 2012.
} 
A questão se torna ainda mais grave quando se considera que os Estados Unidos ainda não se submeteram à jurisdição do Tribunal Penal Internacional (TPI), estabelecido pelo Estatuto de Roma, em 2002, e instalado em Haia, Países Baixos. O objetivo desse Tribunal é promover o Direito Internacional, sendo sua competência julgar os indivíduos e não os Estados, cuja competência é da Corte Internacional de Justiça. Cabe ao TPI julgar os crimes mais graves cometidos por indivíduos como, por exemplo, genocídio, crimes de guerra, crimes contra a humanidade (categoria na qual se insere a tortura). E este julga os responsáveis quando os Tribunais nacionais não puderem ou não quiserem processar os criminosos. $^{12}$

Em suma, nunca existiram tantos aparatos perfeitamente estruturados para a defesa do ser humano no âmbito penal e para a reafirmação da universalidade dos Direitos Humanos. Entretanto, concomitante a existência desses aparatos e ainda em tempos contemporâneos, é possível observar o quanto eles são desrespeitados, de modo que a humanidade parece atuar em retrocesso aos valores que tanto batalhou para serem legitimados e defendidos. Resta aos profissionais de Medicina recusar qualquer participação em atos de tortura e, assim, reconquistarem as diretrizes da Bioética.

\section{A maleficência na tortura}

Médicos que se envolvem em atos de tortura, indicam aos interrogadores o quanto um indivíduo pode suportar a dor durante um interrogatório. A participação de um profissional de Medicina na prática da tortura torna-a mais sofisticada e eficiente, já que ele possui conhecimentos específicos que permite a ciência de como provocar dor, desconforto, sem deixar tantas evidências físicas ou mesmo sem causar o óbito e, assim, alcançar o objetivo pretendido pelo torturador.

Um médico quando requisitado a examinar vítimas de tortura com intuitos legais ou de diagnóstico pode falhar profissionalmente ao realizar suas funções se: falta treinamento profissional, há medo de represálias ou há identificação com as forças policiais. Em outras palavras, não faz a devida análise e documentação sobre a prática de tortura.

\footnotetext{
${ }^{12}$ Site do TPI. Disponível em: $<$ http://www.icc-cpi.int/Menus/ICC/About+the+Court/>. Acesso em: 8 fev. 2012.
} 
Por essa razão é importante a identificação dos principais elementos para a determinação de tortura, quais sejam:

1. A imposição intencional de dor ou sofrimento agudo, seja física ou mental.

2. Através ou com o consentimento ou aquiescência das autoridades do Estado.

3. Para um fim específico, como coleta de informações, punição ou intimidação. ${ }^{13}$

Vive-se a época da informação, desse modo, não há profissional de saúde que poderia argumentar desconhecimento da regra. Em 1975, por meio do Protocolo de Tóquio, a Associação Médica Mundial se manifestou proibindo expressamente o envolvimento de médicos com tortura. ${ }^{14}$ Normalmente, um médico é coagido a auxiliar ou monitorar uma sessão de tortura por uma figura de autoridade. Porém, mesmo em situações como essa, há organismos internacionais que oferecem proteção aos profissionais que não querem se envolver em crimes contra a humanidade. Mas, o que ocorre na realidade?

A imprensa divulgou relatórios da Agência Central de Inteligência dos Estados Unidos (CIA) em que são descritas muitas formas de tortura realizadas com a colaboração de médicos, especialmente em Guantánamo. ${ }^{15}$ Um médico e pesquisador norte-americano, Dr. Steven H. Miles, examinou o envolvimento médico nos casos de tortura e afirmou a necessidade de se começar a punir esses profissionais. ${ }^{16}$

Ante todo o exposto, muitos questionamentos vêm à tona. Os médicos suspeitos de envolvimento com tortura em Guantánamo poderiam ser indiciados por crimes contra a humanidade? A ética médica necessita prever uma penalidade mais rigorosa para coibir esse tipo de conduta lesiva? Nos tempos atuais, qual a solução para a obediência desse preceito básico da ética médica?

\footnotetext{
13 PEEL, M.; LUBELL, N.; BEYNON, J. Investigação Médica e Documentação sobre Tortura - Manual para Profissionais de Saúde, $1^{\mathrm{a}}$ ed., Centro de Direitos Humanos, Universidade de Essex, Grã-Bretanha, 2005, p. 18. Disponível em:

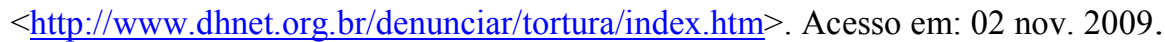

14 Site da Associação Médica Mundial. Disponível em:

$<$ http://www.wma.net/en/20activities/10ethics/20tokyo/>. Acesso em: 08 fev. 2012.

15 RUBENSTEIN, L.S.; ANNAS, G.J., "Medical ethics at Guantanamo Bay Detention Centre and in the US Military: a Time for Reform”, The Lancet, v. 374, Issue 9686, 25 July 2009, pp. 353-355. Disponível em:

$<$ http://www.thelancet.com/journals/lancet/article/PIIS0140-6736(09)60873-4/fulltext>. Acesso em: 02 nov. 2009.

${ }^{16}$ MILES, S. H., "Doctors Complicity with torture”. British Medical Journal, 2008, pp. 337-1088.

Disponível em:

$<$ http://psychoanalystsopposewar.org/blog/2008/07/31/miles-doctors\%E2\%80\%99-complicity-withtorture/>. Acesso em: 02 nov. 2009.
} 
As soluções para prevenir esses crimes serão possíveis a partir do momento em que, mesmo com as duras lições da Segunda Guerra Mundial, as instituições responsáveis admitirem que a tortura continua a ser realizada com auxílio de médicos.

A Bioética evolui a cada novidade científica, mas observa-se que ela ainda não é suficiente para coibir o envolvimento de um médico em um crime contra a humanidade. Assim, torna-se um desafio observar se a atual conjuntura internacional penal e as Cortes de cada país são aptas para julgar e penalizar os envolvidos da classe médica, e quais mecanismos poderiam auxiliar para que esse profissional não seja coagido a participar desses atos.

Desse modo, o presente trabalho tem por objetivo lançar a perspectiva do médico envolvido com tortura, realizando para isso uma breve análise histórica desde a Segunda Guerra Mundial, das técnicas de tortura mais utilizadas e sofisticadas pela ajuda médica, além dos acontecimentos em Abu Ghraib, Guantánamo e Israel.

O envolvimento de médicos em atos de tortura se faz presente em muitos países, e fez parte da história do Brasil durante a Ditadura Militar. O tema em questão mostra que situações-limite, tais como guerras e governos autoritários, proporcionam o afloramento do que há de pior no ser humano. Esse aspecto se torna especial e extremamente perigoso quando se trata de um médico, uma vez que ele pode usar seu conhecimento para o mal.

\section{Objetivo}

O objetivo desta dissertação é verificar se a legislação surgida e se os esforços empreendidos desde a Segunda Guerra Mundial são aptos a inibir o comportamento maleficente de médicos no auxílio ao aprimoramento e acobertamento da tortura. Em um segundo momento, o intuito é propor soluções, caso se verifique que a legislação e os demais esforços se demonstrem inoperantes e pouco eficientes.

\section{Método}

Pelo fato de o tema tratar de uma área interdisciplinar do Direito, serão aplicados métodos vários, a fim de desenvolver uma pesquisa completa e harmônica. 
Por meio do método histórico realizar-se-á uma breve análise da evolução do ato médico no crime de tortura ao longo dos tempos. Em adição, o método dialético desenvolverá o tema mediante a análise das posições clássicas em livros e manuais frente às posições modernas encontradas em artigos eletrônicos de revistas jurídicas e de Medicina, e nos sites de organizações internacionais. Ademais, em razão da maioria da produção literária ser de origem estrangeira o método comparativo também fará parte deste trabalho. 


\section{II - BIOÉTICA, BENEFICÊNCIA E NÃO MALEFICÊNCIA}

Conforme mencionado na Introdução, a Bioética é uma ciência relativamente nova. Mas o que exatamente ela seria? Qual a sua origem?

Segundo o entendimento de José Roberto Goldim, especialista brasileiro no assunto, a primeira aparição da palavra "Bioética" na literatura especializada (Bio+Ethik) foi em 1927, em uma publicação de Fritz Jahr no periódico alemão Kosmos. Para esse autor seria responsabilidade da Bioética não apenas as obrigações éticas com os seres humanos, mas com todo e qualquer ser vivo. Essa noção antecipou a origem do termo "Bioética" em 47 anos, pois ao discorrer sobre o assunto é comum atribuir a origem do conceito a Van Renselaer Potter, bioquímico americano e professor de Oncologia da Universidade de Wisconsin. Potter publicou um artigo em 1970, caracterizando a Bioética como "a ciência da sobrevivência". Ele se preocupava com o desenvolvimento desenfreado da ciência e como isso afetaria a relação entre o homem e o ecossistema. Por sua vez, Jahr, ao final do seu artigo, expõe a proposta de um "imperativo bioético" que "[...] respeita todo ser vivo essencialmente como um fim em si mesmo e trata-o, se possível, como tal!”. ${ }^{17}$

Para Potter, inicialmente, a Bioética constituiria uma ponte entre as ciências e as humanidades, porém, no fim da década de 1980, a ênfase se deu na característica interdisciplinar e abrangente da Bioética, cuja perspectiva passou a ser global, isto é, não se fecharia somente às discussões no âmbito da Medicina e da Saúde, mas se ampliaria aos desafios ambientais. Justamente por isso, Ética da Terra (1930), obra de Aldo Leopold, é tida como fonte de inspiração do trabalho de Potter, pois incluía não apenas os animais e plantas, mas também o solo e os demais recursos naturais para as discussões éticas. ${ }^{18}$

O obstetra holandês, André Hellegers, da Universidade de Georgetown, foi o responsável pela adaptação do termo "Bioética" para a Medicina, também a partir dos anos 1970.

Em 1978 foi elaborado nos Estados Unidos outro marco da Bioética, o "Relatório Belmont" da Comissão Nacional de Proteção dos Sujeitos Humanos da Pesquisa Biomédica, resultado de pesquisas extremamente irregulares e abusivas realizadas com negros sifilíticos no estado do Alabama. Em reparação a esse tenebroso episódio, o

\footnotetext{
${ }^{17}$ GOLDIM, J.R., "Bioética e Complexidade”. In: MARTINS-COSTA, Judith; MÖLLER, Leticia Ludwig. (Orgs.), Bioética e Responsabilidade. $1^{\text {a }}$ ed., Rio de Janeiro, Forense, 2009, v. 1, pp. 55-72.

${ }^{18}$ GOLDIM, J.R., op.cit., p. 56.
} 
objetivo do relatório era determinar os limites éticos das pesquisas com seres humanos por meio de três princípios globais: 1) respeito às pessoas (autonomia); 2) respeito à beneficência; e 3) respeito à justiça. O que isso significava? A partir desse momento questões éticas não seriam mais analisadas mediante a letra dos códigos e juramentos, mas considerando esses três princípios junto dos procedimentos práticos deles decorrentes. ${ }^{19}$ Entende-se, que esses princípios se tornariam uma norma fundamental. Importante ressaltar que até este momento não havia sido organizada uma distinção entre beneficência e não maleficência, uma das contribuições da obra de Tom Beauchamp e James F. Childress.

Em 1979, Tom Beauchamp e James F. Childress publicaram uma importante obra sobre a Bioética - Principles of Biomedical Ethics (Princípios da Ética Biomédica), em que se destacaram os seguintes princípios: não maleficência, justiça, beneficência e respeito à autonomia. Finalmente, surge uma obra cujos autores se preocuparam em aplicar os princípios éticos aos problemas da prática médica assistencial. ${ }^{20}$

Para prosseguir a discussão, é importante diferenciar a noção de moral e ética no universo da Bioética. O termo "ética", cuja origem remonta a palavra grega ethos, denota o "modo de ser" ou o "caráter" adquirido pelo homem, pelo indivíduo. Por sua vez, "moral" vem do latim mos ou mores (costumes), e significa "alguma coisa que seja habitual para um povo". ${ }^{21}$ Segundo o entendimento de Volnei Garrafa, o universo da profissão médica é estigmatizado por um conflito entre a exigibilidade das condutas prescritas por normas universais e a flexibilidade das decisões adequadas em cada caso singular. Para ele, a moral se refere à noção de legitimidade, enquanto a ética se relaciona à noção de legalidade (direito formal, justiça). De acordo com o autor, é preferível confiar nas singularidades culturais e nas diferenças de moralidades encontradas em diversos povos e pessoas do que em certas "verdades universais" e normas jurídicas inflexíveis. ${ }^{22}$ Como exemplo, ele cita a diferenciação entre moral e ética em uma situação limite da Bioética. Uma menina de rua, com 12 anos, prostituta desde os oito, soropositiva e sem família procura por um médico para a realização de um aborto. Apesar de ser católico e saber que

\footnotetext{
${ }^{19}$ BEAUCHAMP, T.L.; CHILDRESS, J.F., Princípios de Ética Biomédica, $2^{\mathrm{a}}$ ed., São Paulo, Loyola, 2011, pp. $10-11$.

${ }^{20}$ GOLDIM, J.R., Princípios Bioéticos. Disponível em: < http://www.ufrgs.br/bioetica/princip.htm>. Acesso em: 20 jun. 2011.

${ }^{21}$ GARRAFA,V., "Bioética e Ciência - Até onde avançar sem agredir", In: COSTA, Sérgio I.F.;

GARRAFA, Volnei; OSELKA, Gabriel., (Orgs.), Iniciação à Bioética, Conselho Federal de Medicina, Brasília, 1998, p. 100. Disponível em:

$<$ http://www.portalmedico.org.br/biblioteca_virtual/bioetica/indice.htm>. Acesso em: 11 jan. 2012.

22 GARRAFA,V., op.cit., p. 102.
} 
no Brasil o aborto constitui um crime, o médico decide realizá-lo. Sua tranquilidade, considerando o histórico da paciente, repousa em não sentir-se culpado por um pecado contra seu Deus, nem por ter infringido o código de ética médica e a legislação penal. É o caso de uma "ética sem moral". Apesar de existir formalmente uma transgressão legal (ética) à Bíblia, ao Código de Ética Médica e ao Código Penal Brasileiro, o médico legitimou sua decisão por meio de sua própria moralidade, impedindo que uma situaçãolimite como essa prosseguisse. Para Garrafa, nesse caso, a responsabilidade é do Estado, que permite tamanho quadro de injustiça social. ${ }^{23}$ Diante dessas noções, observa-se que a moral e a ética também permeiam as decisões dos médicos.

Prosseguindo com a evolução histórica da Bioética, em 1998, Potter resolveu redefinir a Bioética, designando-a de "Bioética profunda" (deep bioethics), dessa vez, a influência vem da obra de Ness sobre Ecologia Profunda. E o que seria a Bioética profunda? Conforme a obra de Goldim:

[...] a nova ciência ética que combina humildade, responsabilidade e uma competência interdisciplinar, intercultural, que potencializa o senso de humanidade. ${ }^{24}$

Assim, a Bioética não pode ser estudada isoladamente. Eis o significado de cada item dessa definição.

Em síntese, o conceito de ética pode ser entendido segundo as ideias de Moore, pela qual seria apenas uma investigação geral sobre aquilo que é bom. ${ }^{25}$ No entanto, a ética não deve ser entendida como um adjetivo, uma presunção que simplesmente define se algo é bom. Ela deve ser pensada como um advérbio, isto é, se uma ética é adequada ou inadequada. Para complementar, Veatch considera a ética a realização de uma reflexão disciplinada das intuições e das escolhas morais que as pessoas fazem. ${ }^{26}$ Portanto, a ética seria uma diretriz das possíveis escolhas de um indivíduo, podendo, assim, demonstrar-se como algo benéfico ou egoístico e maléfico.

No que se refere ao significado da humildade, resumidamente, é possível entendê-la como a percepção de que o ser humano não pode estar certo o tempo todo. Não se pode prever tudo, pois a vida e o universo estão sempre suscetíveis às mudanças, determinando transformações de qualquer resultado. É uma virtude adquirida do caráter.

\footnotetext{
${ }^{23}$ GARRAFA,V., op.cit., p. 102.

${ }^{24}$ GOLDIM, J.R., op.cit., p. 56.

${ }^{25}$ GOLDIM, J.R., op.cit., p. 57.

${ }^{26}$ GOLDIM, J.R., op.cit., p. 58.
} 
As conquistas tecnológicas não podem servir de justificativa para se abrir mão da humildade. De acordo com a Bioética, a humildade é fundamental, porque permite assumir a incerteza e a mudança como componentes sempre presentes, além de tornar passível de discussão qualquer resultado de reflexões. Não há nada definitivo ou imutável, por isso a Bioética permite que todas as variáveis possíveis sejam avaliadas. ${ }^{27}$

Em uma época mais remota, anterior aos pensamentos de Potter, a responsabilidade se restringia apenas ao círculo das pessoas que viviam aquele momento histórico. Por meio da Bioética profunda e das ideias de Leopold, faz-se necessário inserir na equação um pensamento sobre a posteridade, sobre o legado para as gerações futuras, por exemplo, um ambiente preservado. Assim, qualquer noção de responsabilidade a partir desses estudiosos passa a ter um viés global, em que o universo, os indivíduos e suas respectivas atitudes são afetados como um todo, direta e indiretamente.

Por sua vez, a competência interdisciplinar da Bioética se traduz na interação entre as pessoas, em outras palavras, na troca de saberes e opiniões, para a qual alguns requisitos são necessários: a existência de uma linguagem e de objetivos comuns; o reconhecimento das diferenças existentes; o domínio dos conteúdos específicos de cada interlocutor e a elaboração de uma síntese complementar. ${ }^{28}$ Esse sistema precisa ser aberto, de modo que permita a interação com elementos externos, intercambiando informações para além de seus limites. Somente assim, um problema proposto para reflexão bioética pode chegar a possíveis soluções.

A questão intercultural poderia ser um desdobramento da interdisciplinaridade, já que configura-se como resultado do reconhecimento da humildade e da tolerância entre diferentes grupos e culturas. O mais relevante é não determinar apenas um modo de encarar a realidade, considerando-o o único correto. Diante de uma cultura diferente, é preciso observar e considerar um problema mediante o ponto de vista daquela determinada cultura.

De tal sorte, a noção de senso de humanidade nunca foi tão importante quanto nos dias de hoje. Em seu artigo, Goldim faz menção ao que Schneewind escreveu sobre a possibilidade de as interações entre os seres humanos migrarem de um comportamento egoísta - em que o outro é utilizado por mim para atingir meus próprios objetivos - para um comportamento altruísta, em que o indivíduo se doa integralmente para o outro. Para Goldim há um estágio anterior a esses dois comportamentos (uso e doação), no qual há

${ }^{27}$ GOLDIM, J.R., op.cit., p. 59.

${ }^{28}$ GOLDIM, J.R., op.cit., p. 61. 
uma troca sincera entre os participantes, a isso se dá o nome de solidariedade. Nela surge a compreensão da importância do outro para o próprio reconhecimento de si mesmo. Nesse sentido, para Comte-Sponville:

Bioética, como se diz hoje, não é uma parte da Biologia; é uma parte da Ética, é uma parte de nossa responsabilidade simplesmente humana; deveres do ser humano para com outro ser humano, e de todos para com a humanidade. ${ }^{29}$

Assim, o conceito de humanidade é inerente ao de Bioética, e se pauta em uma postura íntegra frente ao outro, à sociedade e à natureza. Ao unir as ideias de Potter e Jahr, Goldim definiu a Bioética como uma reflexão compartilhada, complexa e interdisciplinar sobre a adequação das ações que envolvem a vida e o viver. ${ }^{30}$

A beneficência, por sua vez, em seu significado filosófico moral, se relaciona a fazer o bem. Suas características estão pautadas em uma disposição emotiva que busca fazer bem aos outros, a uma qualidade do caráter das pessoas (virtude), a uma disposição para agir de forma correta e que, de modo geral, entende-se que todos os seres humanos normais a possuam. ${ }^{31}$ De acordo com o filósofo William David Ross, a beneficência e a não maleficência são deveres independentes e condicionais (ou não absolutos). ${ }^{32} \mathrm{~A}$ Medicina é considerada uma atividade humana que, por necessidade, constitui uma forma de beneficência. Esse princípio tenta, em um primeiro momento, promover a saúde e a prevenção da doença. Em segundo, pesa os bens e os males buscando a prevalência dos primeiros. Em sentido estrito, a beneficência, de acordo com o Relatório Belmont, é uma dupla obrigação: a de não causar dano e maximizar o número de possíveis benefícios. Por sua vez, para Beauchamp e Childress, o não causar dano reside na não maleficência. ${ }^{33}$

Para ambos estudiosos, a beneficência se refere a uma ação realizada em benefício dos outros, ${ }^{34}$ são algumas de suas regras: proteger e defender os direitos dos outros, evitar que os mesmos sofram danos, eliminar condições que causarão danos a outrem, ajudar pessoas inaptas e socorrer as que estão em perigo. ${ }^{35}$

\footnotetext{
${ }^{29}$ GOLDIM, J.R., op.cit., p. 67.

${ }^{30}$ GOLDIM, J.R., op.cit., p. 68.

${ }^{31}$ KIPPER, D.J.; CLOTET, J., "Princípios da Beneficência e não Maleficência”, In: COSTA, Sérgio I.F.; GARRAFA, Volnei; OSELKA, Gabriel., (Orgs.), Iniciação à Bioética, Conselho Federal de Medicina, Brasília, 1998, p. 100. Disponível em:

$<$ http://www.portalmedico.org.br/biblioteca_virtual/bioetica/indice.htm>. Acesso em: 11 jan. 2012.

${ }^{32}$ KIPPER, D.J.; CLOTET, J., op.cit., p. 43.

${ }^{33}$ KIPPER, D.J.; CLOTET, J., op.cit., p. 45.

${ }^{34}$ BEAUCHAMP, T.L.; CHILDRESS, J.F., op.cit., p. 282.

${ }^{35}$ BEAUCHAMP, T.L.; CHILDRESS, J.F., op.cit., p. 284.
} 
É importante acentuar que a beneficência não pode ser aplicada pelos médicos de modo absoluto, pois ao entrar em choque com os outros princípios, como a autonomia, deve-se respeitar a dignidade da pessoa, que se tornará um princípio condicional, para não prejudicar o paciente. Por exemplo, a continuidade de tratamentos (normalmente fúteis) em um paciente terminal, em que apenas se prolonga o sofrimento, referida atitude não apresenta benefícios, de modo que a preservação da vida não caracteriza o bem maior. ${ }^{36}$ Não pode haver primazia da beneficência, porque isso levaria ao paternalismo, em que se toma a ação contrariando as preferências do paciente em nome de uma beneficência cega e passível de causar danos, gerar dor e sofrimento. ${ }^{37}$

Portanto, diante do princípio da beneficência, pode-se concluir que a Medicina previne, diagnostica, trata, sempre consola, às vezes cura e nunca mata.

No que se refere a não maleficência, suas origens remontam à tradição hipocrática, de socorrer e não causar dano. É óbvio que o exercício da Medicina pode causar danos em prol de um benefício maior, por exemplo, um braço amputado para a preservação da vida. O interesse principal não é cortar o braço, mas sim a saúde geral. ${ }^{38}$ Assim como a beneficência, a maleficência também não apresenta caráter absoluto. Uma dor ou dano causado só pode ser justificado se for um benefício direto ao paciente. Somente em segundo e terceiro lugar deve constituir um benefício para a família, para outros pacientes e para toda a sociedade. Importante esclarecer que no passado o princípio de "não causar danos" era interpretado de acordo com as circunstâncias históricas e as instituições. ${ }^{39} \mathrm{Em}$ outras palavras, o dano se tornava um mal necessário e a beneficência ficava em segundo plano. Provavelmente, isso motivou os abusos cometidos por médicos durante a Segunda Guerra Mundial, como se estudará no Capítulo IV.

Para Beauchamp e Childress, o princípio da não maleficência determina a obrigação de não infligir dano intencionalmente. ${ }^{40}$ Dessa forma, é possível imaginar que o dano que provoca um benefício seria "aceitável". Entretanto, a maleficência, pura e simples, se caracteriza pela causa de uma dor ou sofrimento por si só, não visando ao bem do paciente. E nesse aspecto muito se aproxima da noção de tortura.

Nesse sentido, em Principles of Biomedical Ethics, a distinção conceitual entre não maleficência e beneficência se caracteriza no fato de a primeira ser o não dever infligir o

\footnotetext{
${ }^{36}$ KIPPER, D.J.; CLOTET, J., op.cit., p. 46.

${ }^{37}$ BEAUCHAMP, T.L.; CHILDRESS, J.F., op.cit., p. 298.

${ }^{38}$ KIPPER, D.J.; CLOTET, J., op.cit., p. 47.

${ }^{39}$ KIPPER, D.J.; CLOTET, J., op.cit., p. 48.

${ }^{40}$ BEAUCHAMP, T.L.; CHILDRESS, J.F., op.cit., p. 209.
} 
mal ou o dano, enquanto a segunda se ramifica em três deveres: 1) o dever de impedir que ocorram males ou danos; 2) o dever de saná-los e 3) o dever de fazer ou promover o bem. ${ }^{41}$

Ao ponderar as discussões para os próximos capítulos é importante ter em mente que ao compactuar com uma sessão de tortura, um médico viola tanto a beneficência quanto a não maleficência, seja por auxiliar ou se omitir ao presenciar, não oferecer tratamento, ou até mesmo não denunciar.

Na obra de Beauchamp e Childress, há exemplificação dos tipos de danos e quais regras morais a não maleficência abarcaria, dentre elas, não matar, não causar dor ou sofrimento aos outros, não causar incapacitação nem ofensa a outros, não despojar outrem dos prazeres da vida. ${ }^{42}$

No choque entre beneficência e não maleficência observa-se que algumas vezes pode haver a primazia da beneficência, especialmente nos casos em que há produção de um benefício importante em detrimento de um dano "pequeno", seguindo uma noção de utilitarismo.

Para encerrar a ideia de beneficência e não maleficência tem-se que a aplicação eticamente correta dos princípios supramencionados é o resultado do exercício da prudência que sempre deve acompanhar toda atividade e decisão do profissional de saúde. A prudência é a virtude que facilita a escolha dos meios certos para um bom resultado. ${ }^{43}$

Beauchamp e Childress são autores principialistas, mas não completamente absolutistas. Defendem em sua obra que a Bioética não podia ser reduzida a uma ética da eficiência aplicada a um nível predominantemente individual, a partir desse pensamento, realizaram análise de casos e concluíram sua obra com o seguinte ensinamento:

Quase todas as grandes teorias éticas convergem na conclusão de que o mais importante ingrediente na vida moral da pessoa é o desenvolvimento de caráter que cria a motivação íntima e a força para fazer o que é certo e bom. ${ }^{44}$

Dessa forma, Beauchamp e Childress defendem a solidificação do conceito de beneficência e não maleficência nos profissionais da área da saúde, eliminando por completo a possibilidade de causar um dano intencional a alguém.

Para os autores os dilemas morais surgem do conflito entre princípios e regras morais, por exemplo, o pobre que rouba comida para saciar a fome de sua família, a mãe

\footnotetext{
${ }^{41}$ BEAUCHAMP, T.L.; CHILDRESS, J.F., op.cit., p. 212.

${ }^{42}$ BEAUCHAMP, T.L.; CHILDRESS, J.F., op.cit., p. 214.

${ }^{43}$ KIPPER, D.J.; CLOTET, J., op.cit., p. 50.

${ }^{44}$ BEAUCHAMP, T.L.; CHILDRESS, J.F., op.cit., p. 13.
} 
que mata um dos filhos para salvar o outro etc. Nessas situações, a única alternativa de cumprir o próprio dever é transgredir outro. Independente da escolha, um caminho é abandonado. É impossível imaginar um contexto em que se realizam as duas ações. A atitude a ser tomada é a de cumprir a obrigação que entra em choque com aquilo que seríamos obrigados a fazer se não fosse pelo conflito. ${ }^{45}$ Nesse sentido, podemos imaginar que um médico-militar, coagido a obter uma informação de um detento, gesto que pode significar a segurança de milhares de vidas, ameaçados pela explosão de uma bomba, por exemplo, entra em confronto com sua noção de não causar um dano a outro ser humano (uso da tortura no interrogatório). Qual dos valores vence? É o que será discutido nos capítulos IV e V.

Tendo em vista o exposto neste capítulo, percebe-se que a Bioética traça diretrizes que ajudam na reflexão sobre os médicos envolvidos em crimes de tortura. Trata-se de uma ciência que irá se conectar com os capítulos seguintes no sentido do descumprimento dos seus princípios, em especial a beneficência e a não maleficência, por parte dos profissionais da saúde. Até aqui foram estruturadas as bases de valores a serem observados nos cenários problemáticos dos próximos capítulos. Além disso, a Bioética será essencial para a reflexão de como pode ser resolvida a questão do envolvimento médico no crime de tortura e de como os profissionais, ainda no curso de graduação, podem aprender com esses ensinamentos e resgatar os valores dessa ciência para sua geração e para as gerações futuras.

${ }^{45}$ BEAUCHAMP, T.L.; CHILDRESS, J.F., op.cit., p. 27. 


\section{III - O CRIME DE TORTURA E A EVOLUÇÃO DA NOÇÃO DE CRIMES INTERNACIONAIS}

Este capítulo tem o propósito de mostrar como determinados crimes, devido à sua gravidade, foram elencados à categoria de crimes internacionais, e como a tortura, por ser um crime internacional, deve ser punida. Além disso, irá expor a construção e a evolução histórica do aparato mais sofisticado de julgamento de crimes internacionais: o Tribunal Penal Internacional.

Os erros do passado permitem compreender o presente e prever alguns possíveis atos futuros. Os equívocos ajudam, inclusive, a assumir atitudes preventivas para evitar que os mesmos erros se repitam. Dessa forma, este capítulo apresenta um contexto histórico indispensável para a correlação dos conteúdos seguintes e os modos de sancionar os médicos envolvidos em crimes de tortura.

\section{a) Diferença entre Direito Internacional Penal e Direito Penal Internacional}

É inerente ao ser humano a busca pela paz e a reprovação de certos comportamentos, cujos responsáveis são passíveis de penalização. Segundo o "Livro do Gênesis", integrante da Bíblia, Deus proibiu o homem de comer o fruto de determinadas árvores, ao enunciar claramente uma norma proibitiva: "Da árvore da ciência do bem e do mal, dela não comerás". Na advertência, pode-se notar que foi previsto um crime (“alimentar-se desse fruto") e uma sanção (“certamente morrerás”). A consequência concreta do respectivo crime e sanção foi a expulsão de Adão e Eva do Éden.

Além desse exemplo clássico, existem muitas outras demonstrações em que a humanidade anseia a punição dos atos reprováveis, quais sejam: o Livro dos Mortos (Antigo Egito), o Código de Manu, o Código de Hamurábi, os Dez Mandamentos de Moisés, todos contêm proibições a determinadas condutas e uma sanção.

Nesse sentido, ao pensar a "proteção de bens jurídicos fundamentais ao indivíduo e à comunidade, por meio de um conjunto de normas (incriminatórias, sancionatórias e de outra natureza)" como missão do Direito Penal, noção de René Ariel Dotti, e uni-la com a noção de Direito Internacional Público, surge o Direito Internacional Penal. ${ }^{46}$

\footnotetext{
${ }^{46}$ CRETElla NetO, J., Curso de Direito Internacional Penal, Ijuí, Unijuí, 2008, p. 23.
} 
Conforme enuncia o Professor Cândido Furtado Maia Neto, promotor de Justiça e membro da Associação Internacional de Direito Penal, o Direito Penal Internacional e o Direito Internacional Penal ainda se confundem. No primeiro, o Estado tem titularidade para aplicar suas leis aos seus indivíduos mesmo que cometam delitos fora de seu território. Por sua vez, no segundo, as regras são em nome da coletividade, em que os Estados abrem mão de suas soberanias legais para processar e punir qualquer indivíduo, de qualquer nacionalidade, de acordo com a prática de determinados crimes, devidamente convencionados ou celebrados em documentos oficiais (Convenções, Pactos etc.). ${ }^{47}$

Desse modo, o Direito Internacional Público constitui a base da competência do Estado para satisfazer os interesses da comunidade, os deveres dos cidadãos e a soberania das leis, regulando o limite da potestade pública estabelecido nas normas vigentes de caráter universal ou com validade internacional bilateral. O Estado restringe as suas ações pelas próprias leis emanadas do Poder Legislativo.

O Direito Internacional Penal é ramo das ciências jurídicas que trata dos assuntos criminais em uma ordem mundial, com jurisdição e competência para o julgamento e a aplicação de sanções por órgãos vinculados à Justiça Internacional devidamente reconhecida. O maior exemplo: Tribunal Penal Internacional (TPI).

Por outro lado, o Direito Penal Internacional é um direito interno com implicações externas, no qual a soberania da lei penal vai além das fronteiras do país que a elaborou. Assim, trata-se de uma concessão nacional via convenção internacional, na qual se dá valor a uma norma criminal como garantia de igualdade de tratamento, prevalecendo nesses casos o princípio da extraterritorialidade da lei penal, como exceção à regra geral, da soberania e territorialidade da norma penal no espaço (arts. $5^{\circ}, 6^{\circ}$ e $7^{\circ}$ do Código Penal Brasileiro).

No entanto, para Cretella Neto, citando Claude Lombois, o Direito Penal Internacional tem como característica principal o fato de as normas aplicáveis serem as do Direito Interno que, nessa situação, projeta-se para fora da esfera repressiva interna em razão de um elemento de estraneidade. Assim, ele denomina essa disciplina de Direito Penal Extranacional. ${ }^{48}$

\footnotetext{
${ }^{47}$ FURTADO MAIA NETO, C., "Direito Penal Internacional e Direito Internacional Penal”, Site Direitos Humanos Aplicados. Disponível em: $<$ http://www.direitoshumanos.pro.br/artigos.php?id=93>. Acesso em: 26 jun. 2010.

${ }^{48}$ CRETELLA NETO, J., op.cit., p. 27.
} 
Por sua vez, o Direito Internacional Penal versa sobre o Direito Penal material, o processo penal e a execução, segundo a metodologia do Direito Internacional Público, podendo ser chamado de Direito dos Crimes Internacionais. Eis a definição da autora italiana Alessandra Palma:

[...] ramo do Direito Internacional que trata de matéria penal, ou seja, inclui todas as normas jurídicas (em especial costumes e convenções) estranhas ao ordenamento interno, que sancionam os ilícitos penais internacionais, aos quais o Estado deve adequar-se enquanto membro da comunidade internacional. ${ }^{49}$

Diante desses posicionamentos, Cretella Neto defende que para a criação de um Direito Internacional Penal são necessários dois requisitos, a saber: a elaboração de um núcleo de normas penais voltadas à tutela dos Direitos Internacionais da pessoa humana e a criação de órgãos de Justiça Internacional permanentes, que permitam a repressão aos crimes cometidos por indivíduos. ${ }^{50}$

Uma vez estabelecidas essas bases, é importante ressaltar que para a concretização da existência de um Direito Internacional Penal é imperioso existir uma colaboração entre Estados e Organizações Internacionais para se proceder à codificação dos crimes internacionais.

\section{b) Evolução histórica}

Durante muito tempo, desde que ocorreram grandes atentados à dignidade humana no cenário internacional, a humanidade desejou a instituição efetiva de uma Justiça Penal Internacional. À custa de muito sangue derramado esse sonho se tornou realidade com o nascimento do Tribunal Penal Internacional. ${ }^{51}$

Apesar da incrível evolução do Direito Internacional Penal não existe ainda um Código de Crimes Internacionais. O Tribunal Penal Internacional de caráter permanente foi criado somente em 1998, cujo Estatuto entrou em vigor em 2002. Alguns anos mais tarde, já em 2006, o referido Estatuto deu seus primeiros passos ao julgar o suspeito Thomas Lubanga Dyilo da República Popular do Congo, por ter cometido crimes de guerra.

\footnotetext{
${ }^{49}$ CRETELLA NETO, J., op.cit., p. 27.

${ }^{50}$ CRETELLA NETO, J., op.cit., p. 28.

${ }^{51}$ MAZZUOLI, V. O., O Tribunal Penal Internacional e o Direito Brasileiro, $3^{\text {a }}$ ed., São Paulo, Revista dos Tribunais, 2011, p. 21.
} 
No entanto, o resultado de um acontecimento sempre configura a origem de uma série de outros fatos. A seguir, serão expostos os eventos mais importantes que provocaram o panorama atual.

Cretella Neto faz menção ao primeiro fato que envolveu o julgamento de um crime considerado internacional. Em 1474, seria a data do primeiro Tribunal Militar Internacional. Tratou-se do julgamento do cavaleiro Peter von Hagensbusch, em Bresaich, Alemanha, julgado pela Corte do Sacro Império Romano, composto de 28 juízes. As acusações eram de que o cavaleiro teria cometido crimes contra as leis de Deus e da humanidade, no caso, o comandante ordenou a ocupação militar daquela cidade, tratando a população civil de forma desumana. ${ }^{52}$

Há discrepâncias quanto ao sobrenome deste comandante. Assim, confrontando o posicionamento de Cretella Neto com materiais no idioma original, em alemão encontramos que o nome é: Peter Von Hagenbach. Ao fim do julgamento, esse cavaleiro foi decapitado por seus crimes. ${ }^{53}$ É possível, portanto, determinar esse episódio como um marco na história e para o desenvolvimento da noção de crime internacional. O que era estudado apenas como um episódio da história medieval, tornou-se aclamado e conhecido como a Paz de Westfália, em 1648, por meio da qual se santificou a noção de soberania dos Estados. ${ }^{54}$

No ano de 1872, é importante destacar a primeira vontade de criação de um Tribunal Penal Internacional, representada pela figura de Gustave Moynier (1826-1910), um dos fundadores da Cruz Vermelha. Na época, Moynier estava inconformado com a inexistência de tal instituto por conta das crueldades cometidas durante o conflito francoprussiano. No entanto, o projeto de Moynier ainda era deveras ousado para a época. ${ }^{55}$ Esses dois eventos históricos são confirmados na obra de Valerio de Oliveira Mazzuoli. ${ }^{56}$

As Convenções Internacionais de Genebra, em 1854, e a de São Petersburgo, em 1868 , foram as primeiras a atuar em favor de uma melhoria das condições dos militares feridos nos campos de batalha. Com intuito de atenuar as calamidades da guerra, foi proibido o emprego de armas "contrárias às leis da humanidade". Configuraram os

\footnotetext{
${ }^{52}$ CRETELLA NETO, J., op.cit., p. 29.

${ }^{53}$ Site Wikisource: $\quad$ Von Hagenbach. Disponível em: $<$ http://de.wikipedia.org/wiki/Peter_von_Hagenbach>. Acesso em: 28 jun. 2010.

${ }^{54}$ SCHABAS A.W., An Introduction to the International Criminal Court. $3^{\mathrm{a}}$ ed., Cambridge University Press, pp. 1-2. Disponível em:

$<$ http://assets.cambridge.org/97805218/81258/excerpt/9780521881258_excerpt.pdf $>$. Acesso em: 28 jun. 2010.

${ }^{55}$ SCHABAS A.W., op.cit., p. 2.

${ }^{56}$ MAZZUOLI, V.O., op.cit., p. 39.
} 
primeiros textos oficiais de caráter internacional que evocaram a conciliação "das necessidades da guerra com as leis da humanidade".

As Convenções adotadas nas Conferências de Paz em Haia, de 1899 e 1907, previram que mesmo em conflitos armados

[...] as populações e os beligerantes permanecem protegidos e sob o império dos princípios do Direito das Gentes, tal como resulta dos costumes estabelecidos entre as nações civilizadas, das leis da humanidade e das exigências da consciência pública. ${ }^{57}$

São os primeiros esboços de um Direito Humanitário, em que se estabelecem obrigações às quais os Estados aceitam sujeitar-se, com fundamento na existência de leis imanentes.

Somente em 1948, com a Declaração Universal dos Direitos Humanos, tem-se de fato a defesa desses direitos naturais inalienáveis de modo mais explícito.

As primeiras medidas internacionais de proteção a populações civis e militares feridos ou capturados foram adotadas no episódio denominado "Genocídio Armênio", perpetrado pelos turcos-otomanos entre 1915 e 1917. Em 1915, os governos da GrãBretanha, Rússia e França anunciaram às autoridades de Istambul que todos os membros do governo otomano seriam responsabilizados pessoalmente pelos crimes cometidos pela Turquia. Essa advertência, no entanto, permaneceu sem efeito e nenhuma atitude foi tomada. Inclusive, uma autoridade famígera por seus extermínios, Adolf Hitler, reconheceu, anos mais tarde, o Genocídio Armênio, pronunciando-o em um dos seus discursos, em 1939, no qual, após ordenar a matança "sem misericórdia e compaixão" de homens, mulheres e crianças polonesas, concluía: “Afinal, quem fala hoje do extermínio dos armênios?". 58

Na Europa, logo após a fase de prosperidade da sociedade liberal e capitalista, que se iniciou por volta de 1871, houve um estremecimento das disputas territoriais entre as potências e da má distribuição dos benefícios do progresso entre a população. Isso criava um clima de instabilidade constante e o risco de um confronto pairava no ar. Até que, em

\footnotetext{
${ }^{57}$ CRETELLA NETO, J., op.cit., p. 30.

${ }^{58}$ FISK, R., “The Forgotten Holocaust”. The Independent, 2007. Disponível em: $<$ http://www.independent.co.uk/opinion/commentators/fisk/robert-fisk-the-forgotten-holocaust463306.html $>$. Acesso em: 28 jun. 2010.
} 
1914, as previsões se confirmaram, com o início da "guerra que ia acabar com todas as guerras", como se costumava dizer na época. ${ }^{59}$

Por volta de 1914, existiam vários motivos para o acirramento das divergências entre os países europeus. Era grande, por exemplo, a insatisfação entre as nações que haviam chegado tarde à partilha da África e da Ásia. A disputa ostensiva por novos mercados e fontes de matérias-primas envolvia muitos governos imperialistas e as tensões nacionalistas, acumuladas durante décadas, pareciam prestes a explodir. O que estava em jogo eram interesses estratégicos para vencer a eterna competição pela hegemonia no Velho e no Novo mundo. ${ }^{60}$

O assassinato de Francisco Ferdinando (em Sarajevo, Bósnia, junho de 1914) foi o estopim que detonou a Primeira Guerra Mundial, quando as tensões entre os dois blocos de países haviam crescido a um nível insuportável. A expressão Grande Guerra, cunhada para o conflito que pela primeira vez na história envolveu todo o planeta, se justifica pelas proporções que o confronto alcançou, pelo aparato bélico mobilizado e por sua destruição devastadora. As novas armas, fruto do desenvolvimento industrial, e os métodos inéditos empregados nos combates deram aos países capitalistas o poder quase absoluto de matar e destruir. $^{61}$

Em 1919, por meio da assinatura do Tratado de Versalhes, a Primeira Guerra Mundial chegou ao fim. Esse tratado previa a criação de um TPI, um Tribunal Penal Internacional, destinado a julgar o antigo Kaiser alemão, Guilherme II, por "violação suprema contra a moral internacional e a autoridade sagrada dos Tratados". ${ }^{62}$ Foi o começo efetivo da consagração da responsabilidade penal internacional. ${ }^{63}$

Mesmo com a criação, nesse Tratado, do art. 227, que previa a responsabilidade penal do indivíduo e a menção apenas a crimes de guerra, o tribunal não pôde funcionar. $\mathrm{O}$ Kaiser havia se refugiado na Holanda que se recusou a extraditá-lo, alegando o caráter político do crime perpetrado. ${ }^{64}$ Não obstante, também havia falta de vontade política dos países vencedores de obrigar a Alemanha a entregar inúmeros presumidos criminosos de guerra. Naquele momento a prioridade dos Estados era o restabelecimento da paz.

\footnotetext{
${ }^{59}$ MOTA, M.B.; BRAICK, P. R., História: das Cavernas ao Terceiro Milênio., volume único, $1^{\mathrm{a}}$ ed., São Paulo, Moderna, 1997, p. 454.

${ }^{60}$ MOTA, M.B.; BRAICK, P.R., op.cit., p. 455.

${ }^{61}$ MOTA, M.B.; BRAICK, P.R., op.cit., p. 455.

${ }^{62}$ CRETELLA NETO, J., op.cit., p. 31.

${ }^{63}$ MAZZUOLI, V.O., op.cit., p. 39.

${ }^{64}$ NASCIMENTO E SILVA, G.E.; ACCIOLY, H., Manual de Direito Internacional Público, São Paulo, Saraiva, 2002, p. 555.
} 
As consequências do Tratado de Versalhes foram intensas e desencadearam outro grande conflito, uma vez que as nações vencedoras da guerra, lideradas pelos Estados Unidos, França e Inglaterra, impuseram duras condições à Alemanha derrotada. O desejo dos alemães de superar as condições humilhantes desse tratado desempenhou papel importante entre as causas da Segunda Guerra Mundial. ${ }^{65}$

Eis as condições humilhantes impostas para a Alemanha nesse Tratado: restituir a região da Alsácia-Lorena à França; ceder outras regiões à Bélgica, à Dinamarca e à Polônia (corredor polonês); ceder todas as colônias; entregar quase todos seus navios mercantes à França, à Inglaterra e à Bélgica; pagar uma enorme indenização em dinheiro aos países vencedores; reduzir o poderio militar de seus exércitos, limitando-os a cem mil voluntários e proibindo-os de possuir aviação militar, submarinos, artilharia pesada e tanques; o recrutamento militar também foi proibido. Por fim, a culpa pela guerra recaiu inteiramente sobre a Alemanha, fato que facilitou, em um momento posterior, o surgimento do Nazismo. ${ }^{66}$

Em 28 de abril de 1919 foi criada a Liga das Nações, cuja missão era mediar os casos de conflito internacional, preservando a paz mundial. Em 1920, o "Comitê Consultivo de Juristas" recebeu mandato para preparar um Tribunal de Justiça permanente para a Liga das Nações, uma espécie de prolongamento dos princípios de 1919. Entretanto, sem a participação de países importantes, como os Estados Unidos, a União Soviética e a Alemanha, a liga revelou-se um organismo impotente.

O crash da Bolsa de Valores de Nova York, em 1929, atingiu a economia de todos os países e fez o nacionalismo crescer, do mesmo modo que a extrema direita, isto é, os regimes totalitários. Assim, na Alemanha, a partir da implantação do III Reich, o Tratado de Versalhes foi desrespeitado, ocasionando a reorganização das Forças Armadas e o desenvolvimento da produção de armas. Iniciava-se, então, a política de expansão territorial, que proclamava a necessidade de toda a raça germânica, aclamada pelo regime como superior às demais). ${ }^{67}$

A expansão alemã iniciou-se em 1938 com o Anschluss, ou seja, a união da Áustria e da Alemanha. Em seguida, anexou-se a região dos Sudetos (Tchecoslováquia), cuja ocupação foi aprovada pela Conferência de Munique (Alemanha, Itália, França e

\footnotetext{
${ }^{65}$ MOTA, M.B.; BRAICK, P.R., op.cit., p. 457.

${ }^{66}$ MOTA, M.B.; BRAICK, P.R., op.cit., p. 458.

${ }^{67}$ MOTA, M.B.; BRAICK, P.R., op.cit., p. 481.
} 
Inglaterra). Em 1939, a Alemanha realizou um acordo com a Itália e o Japão, do qual nasceu o que ficou historicamente conhecido como o "Eixo" (Roma, Berlim, Tóquio). ${ }^{68}$

Já o governo fascista da Itália conquistou a Abissínia (Etiópia) e a Albânia. No extremo oriente, o Japão anexava a Manchúria e outras regiões da China. A primeira fase da guerra foi marcada pela vitória do Eixo - de 1939 a 1941. A Alemanha adotou a Blitzkrieg - "guerra-relâmpago" - tática de operação combinada (naval, aérea e terrestre). ${ }^{69}$

A Alemanha ocupou a Polônia, Dinamarca, Noruega, Holanda, Bélgica e França, essa última, após a invasão, ficou dividida em duas áreas: uma zona de ocupação nazista e outra "livre", governada pelos simpatizantes do nazismo. Em agosto de 1940, iniciou-se o ataque a Grã-Bretanha, neutralizada pela ação da Força Aérea Britânica (RAF). ${ }^{70}$

Em 1941, o Eixo recebeu apoio da Hungria, Romênia e Bulgária e, neste mesmo ano, ocupou a Iugoslávia e a Grécia. Ainda nesse ano, o comandante Rommel desembarcou junto da sua tropa Afrikakorps com o objetivo de conquistar o canal de Suez. O período de 1941 a 1943 marcou um equilíbrio entre as forças na guerra. Em junho de 1941, a Alemanha deu início à "Operação Barbarossa” - a invasão da União Soviética. A ofensiva nazista, em um primeiro momento, foi vitoriosa. ${ }^{71}$

Em dezembro de 1941, o Japão, durante seu expansionismo pela Ásia, atacou Pearl Harbor, no Havaí (território americano), fato que propicia a entrada dos EUA no conflito. Entre 1943 e 1945 a guerra é marcada pela vitória das forças contrárias ao Eixo. ${ }^{72}$

A Batalha de Stalingrado, vencida pelos comunistas, configura o início da derrocada dos nazistas; em 1944 inicia-se a Operação Overlord (Dia D) e o desembarque dos aliados na Normandia. A Itália já havia se retirado do conflito em julho de 1943. O Japão cede em 1945, após os bombardeios atômicos a Hiroshima e Nagasaki. ${ }^{73}$

A Segunda Guerra Mundial provocou um desenvolvimento da indústria bélica e um grande número de mortes: a União Soviética teve 20 milhões de mortos; os alemães somaram seis milhões e os japoneses um milhão e duzentos mil; vale adicionar a essa conta o extermínio de judeus nos campos de concentração, que chegou a cerca de seis milhões de vítimas. $^{74}$

\footnotetext{
${ }^{68}$ MOTA, M.B.; BRAICK, P.R., op.cit., p. 512.

${ }^{69}$ MOTA, M.B.; BRAICK, P.R., op.cit., p. 513.

${ }^{70}$ MOTA, M.B.; BRAICK, P.R., op.cit., p. 514.

${ }^{71}$ MOTA, M.B.; BRAICK, P.R., op.cit., p. 515.

${ }^{72}$ MOTA, M.B.; BRAICK, P.R., op.cit., p. 514.

${ }^{73}$ MOTA, M.B.; BRAICK, P.R., op.cit., p. 515.

${ }^{74}$ MOTA, M.B.; BRAICK, P.R., op.cit., p. 516.
} 
Em razão das atrocidades cometidas nesse período, os governantes chegaram ao acordo assinado em Londres, no Palácio de St. James, pelo qual foi instituída a Comissão de Crimes de Guerra.

Após a confirmação, em 1944, da ocorrência do extermínio de seis milhões de judeus pelos nazistas, surgiu a necessidade de se conceituar uma nova categoria de crimes: os crimes contra a humanidade.

A Conferência de Potsdam, que contou com a participação de Clement Attlee (GrãBretanha), Harry Truman (EUA) e Stalin (URSS), efetivou a divisão da Alemanha em zonas de influência, a criação de um tribunal para julgar os crimes nazistas (Tribunal de Nuremberg) e a estipulação do pagamento de uma indenização de 20 bilhões de dólares à Inglaterra, URSS, França e EUA. ${ }^{75}$

Após as atrocidades ocorridas na Segunda Guerra Mundial, os Estados se organizaram e criaram a Organização das Nações Unidas (ONU) em prol da instituição e à permanência da paz mundial. Mediante a Carta das Nações Unidas, de 20 de junho de 1945, também chamada Carta de San Francisco, documento fundador da ONU, os povos exprimiram sua determinação, mencionando já no primeiro parágrafo de seu preâmbulo os Direitos Humanos:

\begin{abstract}
Nós, os povos das Nações Unidas, resolvidos a preservar as gerações vindouras do flagelo da guerra, que por duas vezes, no espaço da nossa vida, trouxe sofrimentos indizíveis à humanidade, e a reafirmar a fé nos direitos fundamentais do homem, na dignidade e no valor do ser humano, na igualdade de direito dos homens e das mulheres, assim como das nações grandes e pequenas, e a estabelecer condições sob as quais a justiça e o respeito às obrigações decorrentes de tratados e de outras fontes do Direito Internacional possam ser mantidos, e a promover o progresso social e melhores condições de vida dentro de uma liberdade ampla. ${ }^{76}$
\end{abstract}

Dois anos após a validação da Carta de San Francisco, os Direitos Humanos foram estabelecidos em um documento jurídico autônomo: a Declaração Universal dos Direitos Humanos, a qual reconhece, por meio da comunidade internacional, que a dignidade e o "direito a ter direitos" são imanentes ao homem ou à mulher, não dependendo, em absoluto, de qualquer espécie de título, condição ou fator.

O principal legado do Holocausto na internacionalização dos Direitos Humanos foi a constatação da falta de uma arquitetura internacional de proteção dos mesmos, a fim de

\footnotetext{
${ }^{75}$ MOTA, M.B.; BRAICK, P.R., op.cit., p. 517.

${ }^{76}$ Site da ONU - Brasil. Disponível em: $<$ http://www.onu-brasil.org.br/conheca_hist.php $>$. Acesso em: 28 jun. 2010 .
} 
impedir essas atrocidades. Foi um período da história marcado pelo resgate da cidadania mundial. ${ }^{77}$ Portanto, torna-se necessário apontar dois eventos importantes no pós-guerra que influenciaram a criação do atual TPI: os Tribunais de Exceção.

\section{c) Tribunal de Nuremberg}

A revelação dos milhões de pessoas exterminadas pelos nazistas por motivos raciais e religiosos levou ao Acordo de Londres, em agosto de 1945, que instituiu o Tribunal Militar Internacional de Nuremberg, cujos trabalhos foram encerrados em outubro de 1946. No entanto, o legado desse tribunal constituiu elemento catalisador para o desenvolvimento do Direito Internacional Penal. ${ }^{78}$

O Tribunal de Nuremberg poderia julgar pessoas que tivessem cometido crimes contra a paz e contra a humanidade, ou ainda, crimes de guerra, devendo ser a responsabilidade apurada tanto para indivíduos quanto para membros de organizações (artigo $6^{\circ}$ do Estatuto de Nuremberg). ${ }^{79}$ Pela primeira vez, a posição hierárquica dos acusados (chefes de Estado ou responsáveis oficiais por departamentos governamentais) não poderia isentá-los da responsabilidade pelos crimes cometidos, nem funcionar como atenuante para seus respectivos delitos, nesse sentido, o tribunal marcou uma época de impunidade aos governantes criminosos.

$\mathrm{O}$ art. $3^{\circ}$ do Estatuto de Nuremberg estabelecia que os juízes não poderiam ser recusados pelos advogados de defesa nem pela Promotoria. ${ }^{80}$

Os trabalhos foram iniciados em outubro de 1945, no Edifício da Corte Suprema, em Berlim, com a primeira sessão presidida pelo juiz soviético Nikitchenko. A Promotoria pediu o indiciamento de 24 principais criminosos de guerra e de seis organizações criminosas. $^{81}$

As acusações, das quais todos os réus se declararam inocentes, referiam-se aos seguintes delitos: participação em um plano comum ou conspiração para perpetração de

\footnotetext{
${ }^{77}$ MAZZUOLI, V.O., op.cit., p. 29.

${ }^{78}$ FLORENTINO FERNANDEZ JANKOV, F., Direito Internacional Penal - Mecanismos de implementação do Tribunal Penal Internacional, São Paulo, Saraiva, 2009, p. 23.

${ }^{79}$ CRETELLA NETO, J., op.cit., p. 100.

${ }^{80}$ Estatuto do Tribunal de Nuremberg, em espanhol. Disponível em: $<$ http://www.ehu.es/ceinik/tratados/7TRATADOSRELATIVOSACRIMENESDEGUERRA/CG73.pdf> . Acesso em: 28 jun. 2010.

${ }^{81}$ CRETELLA NETO, J., op.cit., p. 102.
} 
crime contra a paz (crime de conspiração); planejamento, iniciativa e realização de guerras de agressão (crimes contra a paz); crimes de guerra e crimes contra a humanidade. ${ }^{82}$

Os vereditos foram lidos em 1946 e as sentenças de morte foram todas cumpridas em outubro do mesmo ano. Estabeleceu-se a execução por meio do enforcamento, usando o sistema padrão de queda. Os juízes franceses sugeriram a morte por fuzilamento para os militares condenados, segundo o padrão das Cortes marciais. A maioria dos juízes se opôs, de modo que os corpos foram incinerados em um crematório em Munique e as cinzas jogadas em um afluente do Rio Isar. Os condenados à prisão foram transferidos em 1947 para o complexo Spandau, em Berlim, onde cumpriram suas penas. ${ }^{83}$

No que se refere aos médicos envolvidos em atrocidades, será estudado mais detalhadamente no capítulo a seguir, sobre médicos nazistas.

\section{d) Tribunal de Tóquio}

O Tribunal Militar Internacional para o Extremo Oriente era o nome oficial do Tribunal de Tóquio, cujo período de vigência se deu entre 19 de janeiro de 1946 e 12 de novembro de 1948.

O Estatuto do Tribunal de Tóquio, em semelhança ao de Nuremberg, dispunha sobre o fato de que nenhum acusado poderia eximir-se de responsabilidade sob alegação de cumprimento de ordens, defesa padrão utilizada pelos acusados. No entanto, a divergência desse Estatuto em relação ao de Nuremberg se dá justamente na posição hierárquica do acusado configurar elemento atenuante da pena, dado o caráter "divino" da pessoa do Imperador, que permeava a estrutura das forças armadas japonesas. ${ }^{84}$

Os fundamentos do Tribunal de Tóquio situam-se na Declaração de Cairo, de 1943, assinada por representante dos EUA, da Grã-Bretanha e da China, na qual justificam o objetivo da guerra: o de revidar a agressão japonesa. Assim, na Conferência de Potsdam, em julho de 1945, foi determinada a punição aos japoneses que cometeram crueldades aos seus prisioneiros de guerra.

O Japão rendeu-se em setembro de 1945. No ato de rendição estipularam-se os procedimentos e as condições relativas à detenção e ao tratamento que deveria ser dado aos

\footnotetext{
${ }^{82}$ CRETELLA NETO, J., op.cit., p. 103.

${ }^{83}$ CRETELLA NETO, J., op.cit., p. 108.

${ }^{84}$ CRETELLA NETO, J., op.cit., p. 115.
} 
suspeitos de terem cometidos crimes de guerra. Ao mesmo tempo, a recém-criada ONU aprovava uma recomendação para que fosse estabelecido um Tribunal Militar Internacional para julgar os criminosos de guerra no Extremo Oriente. A Conferência de Moscou, realizada pelos Ministros das Relações Exteriores dos Aliados, acordaram sobre a sede do tribunal, Tóquio, e a data, janeiro de 1946, desse modo, o Comandante em Chefe Supremo para as Potências Aliadas, Gen. Douglas MacArthur, aprovou a Carta do Tribunal, ${ }^{85}$ que apesar de seguir os princípios do Estatuto de Nuremberg, apresentava uma organização semelhante a uma Corte marcial ou comissão militar. ${ }^{86}$ Sete réus foram sentenciados à morte, dezesseis à prisão perpétua e dois (um diplomata e um general que havia sido Ministro das Relações Exteriores) receberam penas menores.

Em relação à atitude dos médicos japoneses durante a guerra, o acesso a informações é muito restrito, e os detalhes dos procedimentos nunca são revelados, em virtude da postura japonesa em não admitir o que realmente foi cometido. Além disso, não há tradução desses documentos para idiomas ocidentais. O governo do Japão, embora tenha reconhecido excessos cometidos por suas tropas, jamais apresentou um pedido formal de desculpas pelos crimes de guerra. As vítimas eram, especialmente, filipinos, malaios, vietnamitas, cambojanos, indonésios, burmeses, chineses, bem como os capturados das tropas dos Aliados.

Foi descoberta a existência de uma unidade militar japonesa especializada em realizar experimentos em civis e prisioneiros de guerra na China. A mais notória foi a Unidade 731, comandada pelo general e médico Shiro Ishii, onde presos eram submetidos a amputações, vivissecção (ato de dissecar um ser humano vivo para estudar seus órgãos) sem anestesia, e experimentos com armas biológicas. A dispensa do uso de anestesia se explicava pelo fato de não comprometer os resultados da pesquisa. Alguns presos tiveram sangue de animais injetados em seus corpos. Outro exemplo dos experimentos realizados se dava no inverno e consistia em expor o braço dos prisioneiros ao frio, molhando-o periodicamente até congelar para, em seguida, amputá-lo. O médico repetia esse procedimento até que não restassem mais braços e pernas, apenas cabeça e torso. Depois disso, o preso era usado em experimentos com pestes e patógenos. De acordo com o site Global Security.org, os experimentos da Unidade 731 provocaram três mil mortes e, talvez,

\footnotetext{
${ }^{85}$ CRETELLA NETO, J., op.cit., p. 115.

${ }^{86}$ PERRONE-MOISÉS, C., Direito Internacional Penal: imunidades e anistias, Barueri, Manole, 2012, p. 22.
} 
cerca de 200 mil chineses morreram de peste bubônica, cólera, antraz, resultado dos testes da guerra biológica. ${ }^{87}$

Em 11 de março de 1948, 30 pessoas, incluindo médicos, foram levadas a julgamento, conforme já mencionado. Descartadas as acusações de canibalismo, 23 pessoas foram declaradas culpadas por vivissecção e remoção criminosa de partes do corpo. Cinco pessoas foram condenadas à morte, quatro à prisão perpétua e o resto a penas menores. Em 1950, o General MacArthur comutou todas as sentenças de morte para penas de prisão. Todos os condenados relacionados à vivissecção foram libertados em 1958. No ano de 2006, aos 84 anos, um médico que participou dos horrores da guerra, ex-oficial do Exército Imperial Japonês, Dr. Akira Makino, declarou ter sido ordenado, como parte de seu treinamento, a conduzir o procedimento de vivissecção em cerca de trinta prisioneiros civis nas Filipinas, entre dezembro de 1944 e fevereiro de 1945. As cirurgias incluíam amputações. Semelhante às alegações dos médicos nazistas, analisadas no próximo capítulo, o Dr. Akira Makino afirma que o não cumprimento das ordens, acarretaria sua própria morte, ou seja, não havia escolha para evitar todos os abusos cometidos. ${ }^{88}$

\section{e) Considerações sobre esses tribunais}

Apesar dos excessos cometidos, os referidos tribunais configuraram o primeiro ato concreto das comunidades na criação de uma Justiça Penal Internacional. A seguir alguns dos princípios inseridos na época, mas que, com alguns ajustes, já demonstravam certa modernidade:

1. A responsabilidade penal individual, independente de suas normas de Direito Nacional - o indivíduo responderá por seus atos, não podendo justificá-los em nome de seu Estado.

2. A inexistência da imunidade de jurisdição de chefe de Estado ou de ministro de Estado - somente para crimes considerados internacionais e em um julgamento em nome da comunidade internacional.

\footnotetext{
${ }^{87}$ Site Global Security. Disponível em: $<$ http://www.globalsecurity.org/wmd/world/japan/bw.htm $>$. Acesso em: 30 jun. 2011.

${ }^{88}$ Site BBC News UK. Disponível em: $<$ http://news.bbc.co.uk/2/hi/americas/6185442.stm>. Acesso em: 30 jun. 2011 .
} 
3. A inescusabilidade de "respondeat superior" - no que se refere à criminalização das condutas, a alegação de que elas não eram criminosas pelo simples fato de cumprir ordens de um superior hierárquico não mais escusariam um indivíduo de responsabilidade penal. ${ }^{89}$

\section{f) Críticas aos tribunais}

Alegava-se o fato de conformarem tribunais de vitoriosos, que não respeitavam os princípios de leis ex post facto (lei criada após o fato ocorrido) e do nullum crime, nulla poena sine lege (não há crime, nem pena, sem lei anterior que o preveja). Além disso, não se sabe até hoje porque o Tribunal de Nuremberg foi criado por um Acordo Internacional (Acordo de Londres) e o de Tóquio por meio de uma simples Declaração Militar. ${ }^{90}$ Nesse mesmo sentido, concorda Valerio de Oliveira Mazzuoli, uma vez que a regra basilar do Direito Penal foi violada nos casos em questão: a lei e o juiz não eram pré-constituídos antes do cometimento dos crimes. ${ }^{91}$

Portanto, percebia-se que era necessária a codificação dos crimes internacionais do mesmo modo que a criação de um tribunal permanente, em vez de tribunais ad hoc, impedindo, assim, a ocorrência de injustiças e excessos uma vez mais.

\section{g) Consequências dos Tribunais de Exceção}

Foram consagrados os Princípios de Nuremberg e em 1949 a Comissão de Direito Internacional - CDI - começou a trabalhar na Formulation of the Nuremberg Principles and Preparation of a Draft Code of Offences against Peace and Security of Mankind. Esse draft code se limitou aos crimes contra a paz e a segurança da humanidade. Faltavam, no entanto, a formulação de vários crimes, em especial, a definição de agressão.

Em 1951, o Comitê Especial da Assembleia Geral, criado para elaborar a Minuta do Estatuto para elaboração de um TPI, completou essa tarefa. Fundamentada no Estatuto da Corte Internacional de Justiça, essa Minuta poderia, então, julgar chefes de Estado, mas

\footnotetext{
${ }^{89}$ CRETELLA NETO, J., op.cit., p. 101.

${ }^{90}$ CRETELLA NETO, J., op.cit., p. 99.

${ }^{91}$ MAZZUOLI, V.O., op.cit., p. 36.
} 
não outros funcionários governamentais. Não havia nenhuma menção a responsabilidade penal dos Estados, aspecto já consagrado no final da Primeira Guerra Mundial.

Havia uma dicotomia entre a criação de um Código sobre os crimes internacionais e a criação de um TPI. A comunidade internacional de 1950 estava propensa à criação de um TPI, mas ainda o considerava idealista. Não havia consenso entre as nações, especialmente Grã-Bretanha, Rússia e os EUA.

Os países que haviam apoiado a criação dos Tribunais de Nuremberg e Tóquio não podiam mudar de posição radicalmente e irem contra a criação de um TPI. Mas, naquele momento nenhuma nação estava preparada para aceitar a existência de um TPI. Somente a França, no Conselho de Segurança, se mostrava verdadeiramente favorável. No entanto, fugindo da árdua tarefa de ser o voto decisivo, os países ficavam presos ao debate sobre a “conveniência e legalidade de tal Tribunal”.

Algo que corroborava essa atitude "tímida" para concretizar esses esforços foi a proposição, em 1951, de que o Tribunal Penal Internacional a ser criado apresentaria uma estrutura permanente, mas funcionaria com base nos casos submetidos a seu julgamento.

Assim, o trabalho das Nações Unidas prosseguiu sem nunca concretizar a união entre o "Código de crimes" e a "Criação de TPI". Por razões políticas da época, a definição e a formulação do crime de agressão nunca foi concluída, desse modo, em 1954, tanto o Estatuto que criaria um TPI quanto o draft code, foram deixados em suspensão. De 1954 a 1974 foram criados quatro Comitês que iriam analisar a questão da agressão. A definição a qual chegaram não foi incluída em uma convenção multilateral nem mesmo votada na resolução que a adotou, a única definição se limitou a considerar a agressão um crime político e não jurídico. ${ }^{92}$

O adiamento, por parte da Assembleia Geral, da análise do Projeto do "Draft Code" e do Estatuto do TPI se deu até os anos 1980, com uma sincera impressão de lentidão e estaca zero. Somente em 1989, a Comissão de Direitos Humanos impulsionou a criação de uma Jurisdição Internacional Penal na África do Sul para tratar o Apartheid. ${ }^{93}$

A partir dos anos 1980, uma revolução nos meios de comunicação faz com que os horrores de uma guerra sejam transmitidos em tempo real, também a indignação humana passa a ser universalizada e, consequentemente, a opinião pública se torna mais sensibilizada com as tragédias.

\footnotetext{
${ }^{92}$ CRETELLA NETO, J., op.cit., p. 43.

${ }^{93}$ CRETELLA NETO, J., op.cit., p. 46.
} 
Apenas em 1992 a CDI foi instada a retomar os trabalhos para criação do Estatuto do TPI. Nesse momento, a aceleração dos trabalhos se deu em virtude de dois Tribunais internacionais ad hoc: um para a ex-Iugoslávia e outro para Ruanda.

Em Haia, foi criado um TPI - ex-I - com a incumbência de julgar "pessoas responsáveis por sérias violações do Direito Internacional Humanitário cometidas no território da antiga Iugoslávia desde 1991, de acordo com as normas do Estatuto". Em Arusha, Tanzânia e Ruanda criou-se o TPIR para

[...] julgar as pessoas responsáveis por essas violações graves ao Direito Internacional Humanitário cometidas no território de Ruanda, bem como cidadãos ruandenses responsáveis por essas violações cometidas no território de Estados vizinhos, entre $1^{\circ}$ de janeiro de 1994 e 31 de dezembro de 1994, em conformidade com as disposições contidas no Estatuto. ${ }^{94}$

Assim, diante do fim da Guerra Fria, da criação desses dois tribunais ad hoc além de um novo consenso no Conselho de Segurança não existiam mais empecilhos para retardar a criação de um TPI.

Entre 1996 e 1998 ocorreram seis reuniões de comitês preparatórios em Nova York para a adoção de um TPI. As Organizações Não Governamentais (Ongs) haviam evoluído muito na época e se agruparam em uma forte coalizão, em especial, a Anistia Internacional (seção Francesa) e os Médicos sem Fronteiras. Finalmente, em 17 de julho de 1998 criouse o Tribunal Penal Internacional. No entanto, a iniciativa para elaboração de um Código contendo todos os crimes internacionais permanecia paralisada. ${ }^{95}$

Após tantas informações sobre a criação desse instituto, pode-se, então, afirmar que, conforme o Estatuto de Roma, são crimes internacionais: o genocídio, os crimes contra a humanidade, os crimes de guerra, art. $8^{\circ}$ - Os crimes de guerra também foram inseridos, com inúmeras situações previstas desde as Convenções de Genebra. Em síntese, incluem-se as violações às Convenções de Genebra, de 1949, que abrange tortura, experiência com seres humanos, sofrimento provocado intencionalmente, tomada de reféns, coação de um soldado para lutar em exército inimigo etc. A tortura também está presente no art. $7^{\circ}$ do Estatuto de Roma, nos crimes contra a humanidade:

Para os efeitos do presente Estatuto, entende-se por "crime contra a humanidade", qualquer um dos atos seguintes, quando cometido no quadro de um ataque, generalizado ou

\footnotetext{
${ }^{94}$ CRETELLA NETO, J., op.cit., p. 47.
}

${ }^{95}$ CRETELLA NETO, J., op.cit., p. 48. 
sistemático, contra qualquer população civil, havendo conhecimento desse ataque, [...] f) tortura. $^{96}$

Portanto, é possível afirmar que devido a sua intensa gravidade, a tortura é considerada um crime internacional e do mesmo modo é penalizado em cada Estado por suas legislações internas e pelos acordos e tratados firmados internacionalmente, os denominados tratados internacionais antitortura, por exemplo, a Convenção contra Tortura da ONU (1984).

Apesar de não estar tipificado no Estatuto de Roma, o "crime de agressão" também é considerado um crime internacional. Conforme dispõe o art. $5^{\circ}$ do Estatuto, o Tribunal só exercerá jurisdição sobre os crimes de agressão uma vez aprovado um dispositivo em conformidade com os arts. 121 e 123 do Estatuto, em que se defina o crime e em quais condições o TPI exercerá sua jurisdição. ${ }^{97}$

Além disso, o TPI estabelece que outras condutas também podem ser estabelecidas como crimes internacionais (art. 22.3 - independente do Estatuto). Por exemplo, o terrorismo internacional é incluído como crime internacional.

\section{h) Da situação atual dos Tribunais Penais Internacionais}

Os Tribunais Penais para a ex-Iugoslávia e Ruanda, criados por resoluções do Conselho de Segurança da ONU, são competentes para julgar os crimes cometidos nos territórios daqueles países, por tipificações próprias, e serão extintos quando todos os acusados forem julgados ou morrerem.

O TPI funciona em obediência ao princípio da complementariedade, realizando julgamento apenas quando as justiças nacionais não o fazem adequadamente (exceto nos casos em que a jurisdição é exercida quando da comunicação de uma circunstância por parte do Conselho de Segurança, art. 13b). Por isso, o Estatuto do TPI, contrariando o espírito de sua fundação, não obriga expressamente os Estados a proceder a reformas para facilitar a repressão pelas legislações nacionais.

\footnotetext{
${ }^{96}$ MAZZUOLI, V.O., op.cit., p. 65.

${ }^{97}$ Estatuto de Roma, em português. Disponível em: $<$ http://www.fd.uc.pt/CI/CEE/OI/TPI/Estatuto_Tribunal_Penal_Internacional.htm $>$. Acesso em: 28 jun. 2010.
} 
Os Tribunais internos se tornam competentes a partir do momento em que os Estados onde funcionam apresentam suas convenções subscritas já internalizadas. Os crimes internacionais propriamente ditos são aqueles puníveis com base no Direito Internacional.

Por sua vez, a base para persecução penal e punição de outros crimes considerados internacionais, será o Direito Nacional. Nesse ponto, o Direito Internacional apenas impõe aos Estados que determinada conduta é criminosa. Fala-se em criminalidade indireta com pauta no Direito Internacional e mediada pela via do Direito Interno. São casos de crimes baseados em Tratados, por exemplo, os crimes contra tráfego aéreo e navegação marítima, certos crimes relacionados a drogas, falsificações, tortura e terrorismo. ${ }^{98}$

\section{i) Brasil e o Tribunal Penal Internacional}

A implementação do Estatuto de Roma no Brasil é um assunto em voga. Como visto, apesar de não haver uma obrigatoriedade de implementação do Estatuto de Roma no âmbito interno dos Estados, tal arranjo faz-se necessário, sobretudo, em virtude do compromisso por eles assumido e por força do princípio da complementariedade. Justamente por essa razão, inúmeros Estados-parte já procederam à implementação, adequando seu direito interno às regras do Estatuto. São exemplos: Canadá, Alemanha, França e Trindade e Tobago. ${ }^{99}$

A Alemanha, em 2000, ratificou o Estatuto de Roma, no entanto, contraditoriamente, em junho de 2002, criou um Código Penal Alemão Internacional, que se voltou um objeto de estudo envolvendo ilustres juristas alemães, como Kai Ambos. Em semelhante atitude, o Canadá ratificou o Estatuto de Roma em 07 de julho de 2000, cuja implementação se deu por meio do Crimes Against Humanity and War Crimes Act, de 29 de junho do mesmo ano, que entrou em vigência em 23 de outubro de 2000, antes mesmo da entrada em vigência do Estatuto de Roma. A França, por sua vez, apenas fez alterações

\footnotetext{
${ }^{98}$ CRETELLA NETO, J., op.cit., p. 56.

${ }^{99}$ RODRIGO ALFLEN DA SILVA, P., A Implementação do Estatuto De Roma no Âmbito Interno Brasileiro Ante as Recentes Movimentações no Tribunal Penal Internacional, p. 1. Disponível em: $<$ http://www.publicacoesacademicas.uniceub.br/index.php/prisma/article/viewFile/841/848>. Acesso em: 28 jun. 2010 .
} 
em seu Código de Processo Penal. Coube a Trindade e Tobago a postura mais ousada, o Estado cumpriu a completa adaptação do Estatuto de Roma a sua legislação. ${ }^{100}$

O Brasil ratificou o texto do Estatuto de Roma por meio do Decreto Legislativo $n^{\circ}$ 112, de 06 de junho de 2002, cujo depósito foi realizado em 20 de junho do referido ano e promulgado pelo Presidente da República, por meio do Decreto $\mathrm{n}^{\circ} 4388$, em 25 de setembro de 2002.

É importante acentuar, contudo, que passados todos esses anos a partir da entrada em vigor do Estatuto de Roma e, por sua vez, acrescente-se, do respectivo depósito do instrumento de ratificação pelo governo brasileiro, diferente da Alemanha, Canadá, França e Trindade e Tobago, o Brasil ainda não procedeu à respectiva implementação.

Os trabalhos dirigidos à implementação começaram pouco tempo depois da ratificação do Estatuto pelo Brasil, em 2002. A primeira iniciativa para tal se deu em 2004 mediante a criação de um grupo de trabalho, formado por representantes do governo e da sociedade civil, para elaborar e discutir o projeto de lei de implementação, bem como resolver eventuais questões que estivessem em conflito com a Constituição Federal.

Outro argumento que fortalece a implementação do TPI pelo Brasil é a Emenda Constitucional $n^{\circ} 45$, de 8 de dezembro de 2004, que acrescentou o $\S 4^{\circ}$ ao art. $5^{\circ}$ da Carta Magna, com o seguinte teor:

Art. $5^{\circ}$

$\S 4^{\circ} \mathrm{O}$ Brasil se submete à jurisdição de Tribunal Penal Internacional a cuja criação tenha manifestado adesão.

Dessa forma, por meio do Projeto de Lei $n^{\circ}$ 301, de 2007, o Deputado Dr. Rosinha propõe a tipificação de condutas previstas no Estatuto de Roma, que instituiu o Tribunal Penal Internacional (TPI). Esse projeto prevê que alguns crimes serão de competência da Justiça Militar, desde que previstos no Código Penal Militar, por exemplo, a tortura. Todos os crimes serão de natureza imprescritível e a pena máxima será de reclusão de trinta anos. $^{101}$

Em 23 de setembro de 2008, o projeto foi submetido à Câmara dos Deputados e, após aprovação nessa casa, deverá, ainda, ser remetido ao Senado Federal. Em consulta à

\footnotetext{
${ }^{100}$ RODRIGO ALFLEN DA SILVA, P., op.cit., pp. 6-10.

${ }^{101}$ Site da Câmara dos Deputados. Disponível em: < http://www.camara.gov.br/sileg/integras/439581.pdf> . Acesso em: 28 jun. 2010.
} 
situação atual do projeto, a última intervenção se deu em maio de 2009 e, todavia, permanece a mesma $^{102}$ :

8/5/2009 COORDENAÇÃO DE COMISSÕES PERMANENTES (CCP) Encaminhada à publicação. Parecer da Comissão de Constituição e Justiça e de Cidadania publicado no DCD de 09/05/09, PÁG 18239 COL 01, Letra A.(íntegra)

\section{j) Tribunal Penal Internacional - Outras questões}

A partir de 19 de maio de 2011, 115 países são signatários do Estatuto de Roma, sendo o último Granada, ${ }^{103}$ que passou a integrar a Corte em $1^{\circ}$ de agosto de 2011.

O TPI não é integrado ao Sistema das Nações Unidas, apenas mantém uma relação de cooperação. Com sede em Haia, Holanda, o Tribunal, diferente da Corte Internacional de Justiça, não julga Estados, mas indivíduos, além disso, não possui jurisdição retroativa, podendo somente julgar casos posteriores a $1^{\mathrm{o}}$ de Julho de 2002, data em que o Estatuto de Roma entrou em vigor. ${ }^{104}$

Assim, atualmente, caso um Estado se torne parte no Estatuto, o Tribunal somente poderá exercer sua competência em relação aos crimes cometidos após a entrada em vigor do Estatuto no referido Estado, antes dessa respectiva data é impossível. ${ }^{105}$ O TPI exerce jurisdição sobre os nacionais de um Estado-parte, acusados por um crime cometido em sua própria pátria ou em um país estrangeiro. ${ }^{106}$

O Estatuto de Roma não constitui um tratado comum, sua natureza é muito especial, marcada por normas centrífugas, ou seja, normas que regem as relações jurídicas dos Estados ou dos indivíduos com a chamada jurisdição global ou universal. A denominação centrífuga decorre do fato de serem tratados que saem do centro, em outras palavras, da jurisdição comum, normal, retirando o sujeito ou o Estado de seu território, de

\footnotetext{
${ }^{102}$ Site da Câmara dos Deputados. Disponível em: $<$ http://www.camara.gov.br/proposicoesWeb/fichadetramitacao?idProposicao=343615 $>$. Acesso em: 20 jun. 2011.

${ }^{103}$ Site do TPI. Disponível em: $<\underline{\text { http://www.icc- }}$ cpi.int/Menus/ASP/Press + Releases/Press + Releases $+2011 /$ Grenada + becomes + the +115 th + State + to + join + the + Rome+Statute.htm>. Acesso em: 20 jun. 2011.

${ }^{104}$ Site do TPI. Disponível em: $<$ http://www.icccpi.int $/$ menus/icc/about $\% 20$ the $\% 20$ court $/$ icc $\% 20$ at $\% 20 \mathrm{a} \% 20$ glance $/$ icc $\% 20$ at $\% 20 \mathrm{a} \% 20$ glance?lan $=$ en-GB $>$. Acesso em: 28 jun. 2010.

${ }^{105}$ MAZZUOLI, V.O., op.cit., p. 60

${ }^{106}$ AMARAL JÚNIOR, A., Curso de Direito Internacional Público, 2ª ed., São Paulo, Atlas, 2011, p. 285.
} 
seu centro, para levá-los à autoridade da justiça universal. Desse modo, o TPI é um órgão jurisdicional com alcance universal. ${ }^{107}$

O Tribunal atua em complementariedade, e se intromete na jurisdição de um país somente quando o processo é considerado uma "fachada" para ocultar o crime verdadeiro ou quando o país está em uma situação em que não consegue desenvolver sua atividade jurisdicional, no entanto, caso o sistema judicial nacional já tenha iniciado a investigação e o processo criminal, não é permitido ao TPI interferir. ${ }^{108}$

São três as conjunturas em que o Tribunal Penal Internacional pode intervir, a saber: quando a iniciativa pela interferência parte de um país membro; quando alguma situação é levada pelo Conselho de Segurança da ONU ou quando o Procurador do TPI apresenta, por conta própria, alguma ocorrência. Entre os casos julgados por essa instância estão os crimes cometidos por qualquer nacional dos países ratificantes do Estatuto de Roma ou o responsável por algum dos crimes previstos cometido no território dos signatários. Os crimes internacionais são imprescritíveis. O TPI é mantido economicamente com contribuições dos Estados-parte e por meio de contribuições voluntários de governos, organizações internacionais, indivíduos, corporações e outras entidades. $^{109}$

A pena máxima que o TPI pode aplicar não pode exceder 30 anos, entretanto, em circunstâncias excepcionais, é possível a aplicação da pena de prisão perpétua no caso de crimes extremamente graves, tendo em conta as circunstâncias pessoais do condenado. Também é cabível a aplicação de sanções de natureza civil traduzidas em reparação às vítimas e aos seus familiares. As penas se aplicam a quaisquer indivíduos, independentemente de exercerem cargos públicos ou funções governamentais, retirando qualquer isenção de pena dos chefes de Estado e do governo. ${ }^{110}$

Em relação a um "presídio internacional" e para demonstrar o exposto no parágrafo anterior, tem-se o caso do ex-presidente da Sérvia e da Iugoslávia, Slobodan Milosevic, preso no complexo de Scheveningen, a dois quilômetros de Haia. Essa penitenciária especial ocupa quatro andares, cada um com doze celas, todas patrulhadas por guardas da ONU. As celas de $15 \mathrm{~m}^{2}$ são individuais, possuem chuveiro, toalete, cuba para banho,

\footnotetext{
${ }^{107}$ MAZZUOLI, V.O., op.cit., p. 47.

${ }^{108}$ MAZZUOLI, V.O., op.cit., p. 49.

${ }^{109}$ Site do TPI. Disponível em: $<$ http://www.icccpi.int/Menus/ICC/About+the+Court/Frequently+asked+Questions/>. Acesso em: 28 jun. 2010.

${ }^{110}$ AMARAL JÚNIOR, A., op.cit., p. 289.
} 
cama, escrivaninha, cafeteira, estante para livros, aparelho de rádio e TV com transmissão via satélite. ${ }^{111}$

\section{k) O Tribunal Penal Internacional em ação}

Após estabelecer-se como um Tribunal universal permanente de jurisdição penal, houve encaminhamento à Corte de situações ocorridas em Darfur (Sudão), na África Central, em Uganda e na República Democrática do Congo, em que se cogitaram a prática de crimes internacionais de competência do Tribunal.

Em 19 de abril de 2004, o governo da República Democrática do Congo, Estado cuja vigência do Tratado de Roma se deu em julho de 2002, remeteu formalmente ao Tribunal Penal Internacional a solicitação de providências no sentido de investigar se haviam sido perpetrados crimes de sua respectiva competência em qualquer parte do território do Estado. Após a realização das investigações, o Promotor requereu, em 13 de janeiro de 2006, a prisão de Thomas Lubanga Dyilo.

Lubanga, líder da União Patriótica Congolesa, foi acusado pelos seguintes crimes de guerra: alistamento e recrutamento de crianças como soldados e obrigação das mesmas na participação ativa em hostilidades na República Democrática do Congo. Segundo os arts. 8 (2), b, xxvi e 8 (2), e, vii, do Estatuto de Roma, tais fatos são caracterizados crimes de guerra, de modo que Lubanga é totalmente responsável pelos atos cometidos. ${ }^{112}$

Ante essa conjuntura, a Corte anunciou publicamente, em 10 de fevereiro de 2006, que a Primeira Câmara de Questões Preliminares (Pre-Trial Chamber I), composta no momento da decisão pela juíza Sylvia Steiner e Akua Kuenyehia, e pelo juiz Claude Jorda, emitiu a primeira ordem de prisão contra Thomas Lubanga Dyilo, detido e transferido para Haia, Holanda, em 17 de março de 2006. Atualmente, ele se encontra recolhido à prisão de Haaglanden, em Scheveningen, presídio mencionado anteriormente.

Por conseguinte, o caso foi remetido a julgamento perante a Primeira Câmara de Julgamento do TPI, composta pelos juízes Adrian Fulford, presidente, e René Blattmann e

\footnotetext{
${ }^{111}$ Site do TPI. Disponível em: $<$ http://www.icccpi.int/menus/icc/structure\%20of\%20the\%20 court/detention/detention?lan=en-GB $>$. Acesso em: 28 jun. 2010.

${ }^{112}$ Site do TPI. Disponível em: $<$ http://www.icccpi.int/Menus/ICC/Situations+and+Cases/Situations/Situation+ICC+0104/Related+Cases/ICC+0104+0106/D emocratic + Republic + of + the + Congo.htm>. Acesso em: 28 jun. 2010.
} 
pela juíza Elizabeth Odio Benito. Passados quase sete anos da vigência do Estatuto de Roma, o Tribunal Penal Internacional começou o seu primeiro julgamento, mais precisamente, em 26 de janeiro de 2009.

Contudo, em 4 de março de 2009, ante as fundadas acusações pela prática de crimes de guerra e crimes contra a humanidade, apresentadas pelo Ministério Público, a Primeira Câmara de Questões Preliminares decidiu, ainda, pela decretação da prisão de Omar Hassan Ahmad Al Bashir, Presidente do Sudão. Suspeito de ser criminalmente responsável, enquanto coautor indireto, pela prática de ataques diretos e intencionais contra parte da população civil de Darfur, no Sudão, atitude que resultou em assassinato, extermínio, rapto, tortura e sequestro de uma grande quantidade de cidadãos, além do saqueamento de seus bens. ${ }^{113}$

\section{I) Desafios atuais do Tribunal Penal Internacional}

A Corte tem competência para julgar os responsáveis por crimes de guerra, genocídios e crimes contra a humanidade quando os Tribunais nacionais não puderem ou não quiserem processar os criminosos. Sete nações votaram contra esse projeto (EUA, China, Israel, Iêmen, Iraque, Líbia e Quatar) e outras vinte e uma se abstiveram. Os EUA justificaram seu veto por não concordarem com a independência do Tribunal em relação ao Conselho de Segurança da ONU - ainda que essa autonomia não seja absoluta. Pelo documento aprovado, o Conselho de Segurança poderá bloquear uma investigação se houver consenso entre seus membros permanentes. O governo estadunidense também teme que seus soldados envolvidos em guerras, como as do Afeganistão e Iraque, venham a ser julgados pelo Tribunal. Além das sessões de tortura realizadas em Guantánamo, Abu Ghraib ou outros locais mantidos em segredo.

Os Estados Unidos assinaram o Tratado durante a Presidência de Bill Clinton, em 31 de dezembro de 2000, mas retiraram a assinatura quando George W. Bush foi eleito. A verdade dos fatos, no entanto, é que o presidente Clinton, em uma jogada política, não encaminhou o Tratado para aprovação no Senado, sob alegação de falhas significativas. Por sua vez, o presidente Bush começou a trabalhar ativamente contra o mesmo firmando

\footnotetext{
${ }^{113}$ Site do TPI. Disponível em: $<$ http://www.icccpi.int/menus/icc/situations\%20and\%20cases/situations/situation $\% 20 \mathrm{icc} \% 200205 /$ related\%20cases/icc 02050 109/icc02050109?lan=en-GB>. Acesso em: 28 jun. 2010.
} 
acordos bilaterais de imunidade com outros Estados, por exemplo, a Romênia. Por meio desses acordos, os respectivos Estados se comprometem a não enviar os cidadãos americanos, militares ou funcionários públicos para julgamento perante o Tribunal Penal Internacional. $^{114}$

Após os atentados de 11 de Setembro de 2001 e das operações de guerra subsequentes no Afeganistão e na Palestina, tornou-se praticamente impossível a ratificação do Estatuto pelos Estados Unidos. Dessa forma, em 6 de maio e 28 de agosto de 2002, Estados Unidos e Israel, respectivamente, notificaram formalmente o SecretárioGeral das Nações Unidas da não intenção de integrarem o Tribunal Penal Internacional. ${ }^{115}$

Os atentados ao World Trade Center em 11 de setembro realmente chocaram o mundo e a resposta norte-americana, por meio de uma guerra ao terrorismo, de algum modo ofuscou os avanços do Direito Internacional Penal. Apesar da obscuridade das informações, tanto nas prisões de Guantánamo e Abu Ghraib quanto em outras clandestinas, a tortura era o método de interrogatório aplicado, dessa forma, os princípios da Convenção de Genebra sobre o Tratamento de Prisioneiros de Guerra foram declaradamente violados pela Administração dos Estados Unidos. Resta saber se alguém responderá pelos crimes cometidos. ${ }^{116}$

Conforme Judith Butler, a justificativa usada pelos Estados Unidos a respeito de não concederem tratamento de prisioneiro de guerra aos capturados no Afeganistão, no Iraque ou em outros países se deve a uma noção obsoleta de guerra, em que a pauta é o soldado do Estado nação. Portanto, aqueles que não pertencem oficialmente às Forças Armadas de Estados reconhecidos, em tese, não poderiam reivindicar essa proteção do Direito Internacional. Entretanto, o governo norte-americano deveria conceder o tratamento independente dessa tecnicalidade e aguardar o posicionamento de um "tribunal competente" sobre essa circunstância especial. ${ }^{117}$ Os Estados Unidos não se sentem violadores da Convenção de Genebra, pois, segundo eles, os prisioneiros de Abu Ghraib, Guantánamo e outros presídios clandestinos não têm status de "presos de guerra", logo podem ser submetidos ao tratamento que imaginam ser conveniente.

\footnotetext{
${ }^{114}$ AMARAL JÚNIOR, A., op.cit, p. 286.

${ }^{115}$ MAZZUOLI, V.O., op.cit., p. 43.

${ }^{116}$ PERRONE-MOISÉS, C., op.cit., p. 38.

${ }^{117}$ BUTLER, J., “O Limbo de Guantánamo”. Novos estudos - CEBRAP [online]. 2007, n. 77, pp. 223-231. Disponível em: $<$ http://www.scielo.br/scielo.php?script=sci_arttext\&pid=S0101-33002007000100011 $>$. Acesso em: 28 jan. 2011.
} 
Segundo a Convenção contra a Tortura das Nações Unidas, todos os países signatários, incluindo os Estados Unidos, comprometem-se a investigar qualquer caso de tortura, a criminalizá-lo, a levar os responsáveis a um Tribunal Penal Nacional e puni-los com base na legislação nacional. O mais interessante é que nos Estados Unidos existe uma legislação específica para punir a tortura. Por questões políticas, a justiça ainda não prevaleceu até o presente momento, é sabido que os militares envolvidos nos escândalos de Abu Ghraib foram julgados e condenados durante o governo Bush, mas e quanto aos médicos envolvidos?

Sem o apoio norte-americano, o TPI ainda carece de força para ser visto com maior seriedade por toda a comunidade internacional. Enquanto os Estados Unidos, Israel, China e os demais países prosseguirem com os indícios de violação dos Direitos Humanos, por meio de práticas criminais que lhes são convenientes, o TPI será apenas um Tribunal para “determinados países" e não verdadeiramente um Tribunal Internacional, cuja jurisdição deveria ter um alcance global.

Muitos dos questionamentos oriundos neste trabalho já apresentam suas respostas. Por exemplo, os médicos-militares americanos envolvidos com a prática de tortura em Guantánamo jamais poderiam ser indiciados segundo as premissas do Tribunal Penal Internacional, uma vez que os Estados Unidos não aceitaram a jurisdição da Corte, a qual julga apenas casos de países que a integra. Sob essa perspectiva, outro questionamento vem à tona: se todos os crimes cometidos pelo governo americano não foram julgados até agora, porque ainda não aceitam a incorporação ao TPI? Uma das respostas prováveis envolve o interesse do governo e do exército americano na preservação de práticas de tortura para obtenção de informações sobre eventuais ataques terroristas, independente do fim da era Bush, mas tendo em vista a política diplomática de Barack Obama.

O papel do TPI para o futuro da humanidade é deveras importante no sentido de processar e julgar os responsáveis pela prática dos piores e mais bárbaros crimes cometidos no planeta, dos quais não se admite o esquecimento. O Tribunal constitui um instrumento único que corrobora a fé nos Direitos Humanos fundamentais e na dignidade da pessoa humana. ${ }^{118}$

Por fim, a razão deste capítulo é demonstrar que existe um ordenamento sofisticado internacional para julgar crimes internacionais, em especial a tortura. Ao mesmo tempo, é triste, constatar que certos países com fortes indícios de violação dos Direitos Humanos

${ }^{118}$ MAZZUOLI, V.O., op.cit., p. 107. 
não irão responder por esse crime perante a Corte do TPI, justamente por não se submeterem a ela. Resta, no entanto, a esperança de que os responsáveis serão julgados em seus respectivos países, já que signatários da Convenção Contra Tortura da ONU. É importante ressaltar que em qualquer local do mundo, em qualquer Estado, a tortura é cometida em clandestinidade. Mas se existe um aparato jurídico para julgar esses criminosos, o que falta são condições para acessá-lo, de modo que essa prática medieval seja completamente abandonada. Este capítulo também expõe a possibilidade de penalização de médicos que auxiliam direta ou indiretamente a tortura, sendo, inclusive, julgados no passado em Tribunais de Exceção. Atualmente, existe o TPI, as convenções internacionais, as Organizações Não Governamentais em defesa dos Direitos Humanos e as associações médicas, ou seja, há uma arquitetura completa para sanção dessas atrocidades. Nos próximos capítulos, serão estudados os motivos da preservação desses crimes ainda hoje, a persistência da impunidade, como fazer para prevenir e que legado deixar para as próximas gerações de profissionais médicos. 


\section{IV - MÉDICOS NAZISTAS E O SURGIMENTO DO CÓDIGO DE NUREMBERG}

O capítulo anterior tratou amplamente sobre a evolução histórica do Tribunal Penal Internacional até a sua atuação e conjuntura atual, para a qual os abusos ocorridos durante a Segunda Guerra Mundial tiveram um enorme impacto, pois muitas atrocidades foram cometidas sob o argumento de que "aquilo não estava estabelecido em legislação alguma como delito".

A partir disso e pensando os profissionais de Medicina que realizaram o juramento de Hipócrates, segundo o qual é claramente sabido que não se deve causar mal a um paciente, pergunta-se: o que houve com os médicos a serviço de Hitler? Ignoraram por completo esse juramento?

As pesquisas médicas conduzidas nos campos de concentração durante a Segunda Guerra Mundial somente em um momento posterior foram consideradas crimes contra a humanidade. Além das experiências, existia o chamado "Programa de eutanásia" (Euthanasieprogramm). ${ }^{119}$

Esse programa consistia em uma determinação de Hitler, de outubro de 1939, por meio dela a Alemanha nazista implantou a Aktion T4, um programa de eliminação de vidas indignas. Inicialmente, as vítimas eram recém-nascidos e crianças de até três anos. Os médicos e parteiras tinham o dever de notificar a autoridade sanitária sobre casos de retardo mental, deformidades físicas e outras condições limitantes. Uma junta médica de três profissionais examinava cada caso e a eliminação somente era realizada quando houvesse unanimidade. Rapidamente o programa se estendeu para adultos e idosos. ${ }^{120}$

Os pacientes que deveriam ser notificados eram portadores de esquizofrenia, epilepsia, desordens senis, paralisias que não respondiam a tratamento, sífilis, retardos mentais, encefalite, doença de Huntington e outras patologias neurológicas. Também eram incluídos os pacientes internados há mais de cinco anos ou criminalmente insanos. Ao longo do tempo, passou-se a considerar os critérios de não possuir cidadania alemã, ou ascendência alemã, discriminando especialmente negros, judeus e ciganos.

\footnotetext{
${ }^{119}$ ROXIN, C. “A Apreciação Jurídico Penal da Eutanásia”. Revista Brasileira de Ciências Criminais, ano 8, out.-dez., 2000, São Paulo, Revista dos Tribunais, 2000, p. 10, trad. Luis Greco.

${ }^{120}$ GOLDIM, J.R., Eutanásia - Alemanha Nazista 1939-1941. Disponível em:

$<$ http://www.ufrgs.br/bioetica/eutnazi.htm>. Acesso em: 13 dez. 2011.
} 
O programa foi interrompido em agosto de 1941, em razão dos protestos do povo, que havia tomado conhecimento dessa prática. ${ }^{121}$

A eutanásia que se menciona durante a Segunda Guerra Mundial em muito se distancia da noção atual, pois não havia o interesse de minorar o sofrimento de uma pessoa capaz e informada de sua condição de saúde. A prática nazista se aproximava muito mais de noções de eugenia, em que era importante descartar os "inúteis da sociedade".

De acordo com Francisco Muñoz Conde em sua obra Edmund Mezger e o Direito Penal de seu Tempo, existia a lei de prevenção de descendência patológica hereditária, em outras palavras, a esterilização forçada de pessoas cuja enfermidade podia ser transmitida aos seus descendentes. Assim, eram esterilizados esquizofrênicos, epiléticos, surdos, cegos e, inclusive, quem sofria de alcoolismo grave. A solicitação partia do próprio médico ou diretor do hospital, mas a decisão última era de um Tribunal de Saúde Hereditária e levada a cabo por pessoal especializado. ${ }^{122}$

O psiquiatra americano Dr. Robert J. Lifton pesquisou por muito tempo e entrevistou vários médicos alemães que serviram o III Reich de Hitler. Como resultado, escreveu a obra The Nazi Doctors: Medical Killing and the Psychology of Genocide publicada em 1986 e disponível na íntegra na Internet.

A introdução da referida obra traz uma pergunta a um médico, Dr. Fritz Klein, sobre como ele conseguia conciliar o Juramento Hipocrático com as obrigações impostas pela SS. A resposta foi a seguinte: "É claro que sou médico e quero preservar a vida. E em respeito a uma vida humana eu removeria um apêndice gangrenado de um corpo doente. Os judeus são o apêndice gangrenado no corpo da humanidade". ${ }^{123}$

Em um primeiro momento, se percebe que havia uma distorção a respeito dos deveres de um médico, nesse sentido, é interessante observar nesta obra que os médicos julgados posteriormente pelos crimes cometidos durante o período da Segunda Guerra Mundial foram condenados por participação nas matanças. Isso se deve ao fato de não haver um mínimo entendimento sobre o que ocorria nos campos de concentração. Não se saberia em que tipo penal "enquadrar".

\footnotetext{
${ }^{121}$ ROXIN, C., op.cit., p. 32.

${ }^{122}$ CONDE, F.M., Edmund Mezger e o direito penal de seu tempo - Estudos sobre o Direito penal no nacional-socialismo, Rio de Janeiro, Lumen Juris, 2005, p. 174.

${ }^{123}$ LIFTON, R.J., The Nazi Doctors: Medical Killing and the Psychology of Genocide, Basic Books, United States of America, 1986, p. 16. Disponível em: < http://www.holocaust-history.org/lifton/LiftonT016.shtml $>$. Acesso em: 20 jun. 2011.
} 
Uma testemunha dos julgamentos dos médicos de Nuremberg disse que os nazistas distorceram completamente o Juramento Hipocrático, reconduzindo a profissão médica e, consequentemente, toda a nação germânica, a serviço de uma "cura mais alargada". ${ }^{124}$ Em outras palavras, a noção de beneficência se devia em larga escala à cura de toda uma nação, mesmo que para isso fossem necessários certos sacrifícios. A vida humana não era a mesma para todos, alguns cidadãos eram considerados "vidas indignas" e "desperdício de espaço".

$\mathrm{Na}$ época de ascensão do partido nazista, vislumbraram intervenções sobre como seria o ensino de Medicina nas faculdades. Metaforicamente, realizava-se uma espécie de lavagem cerebral a fim de influenciar o pensamento dos jovens médicos. Inclusive, a partir desse momento, iniciavam-se boicotes a professores de Medicina de origem judaica, de modo que os estudantes e profissionais que desejavam promoções e oportunidades na carreira passavam a defender ardentemente os ideais nazistas. ${ }^{125}$ A profissão era enobrecida e constituía uma verdadeira honra servir seu país como médico. Dessa forma, todos se voltavam favoráveis às leis de esterilização que surgiam. ${ }^{126}$ Os professores que se recusavam a participar eram imediatamente denunciados. ${ }^{127}$ Tudo era arquitetado para que o aparato estatal, educacional, sanitário, cultural, não tivesse escolha a não ser o envolvimento e o engajamento a essas ideias. Do contrário, restava a perseguição, a prisão ou mesmo a morte.

Um médico expressou seus sentimentos ambíguos e de culpa a respeito de suas atitudes à época:

Well, there is an enormous difference if one says the patients who fall under these provisions are unworthy of life, that they should be killed - that is still a provision, you know - but the actual carrying it out, that is the big problem, see. Who will do this thing? I believe those gentlemen who engaged in such theoretical reflections never reflected on that .... No judge who gave the verdict of death has ever hanged anyone, you see .... I can say a hundred times, "He [a patient] is such a mental defective that he can never develop at all," . . . etc., etc. but that does not enable me to kill him [umzubringen; literally, "put [him] away"]. ${ }^{128}$

\footnotetext{
${ }^{124}$ LIFTON, R.J., op.cit., p. 32.

${ }^{125}$ LIFTON, R.J., op.cit., p. 37.

${ }^{126}$ LIFTON, R.J., op.cit., p. 38.

${ }^{127}$ LIFTON, R.J., op.cit., p. 39.

128 "Bom, há uma enorme diferença quando alguém fala que os pacientes submetidos a essas medidas são indignos de viver e que devem ser mortos - isso é ainda uma medida, sabe - mas efetivamente executá-la, esse era o maior problema. Quem fará isso? Acredito que os cavalheiros que se engajavam nessas reflexões teóricas nunca pensaram nisso ... Nenhum juiz que condena à morte já enforcou alguém, veja ... Posso dizer isso mil vezes, "Ele [o paciente] possui tamanho defeito mental que nunca irá se desenvolver," ... etc., etc. mas isso não me permite matá-lo [umzubringen; literalmente, "apagar [o sujeito]"]. (LIFTON, 1986, p. 60) . Tradução da autora.
} 
Era muito simples para um médico de alto escalão determinar aos profissionais mais jovens que exterminassem os considerados "vidas indignas". Assim, a maioria dos médicos que executava as ordens tinha ciência sobre o erro que estavam cometendo ao encerrar uma vida daquela maneira, mas simplesmente não sabiam ou não eram capazes, devido a hierarquia a que estavam submetidos, de recuperar o controle da situação.

Na obra de Daniel Jonah Goldhagen há relatos sobre a participação de médicos em matanças de judeus dentro do Batalhão Policial 101, grupo conhecido como "esquadrão da matança". Interessante notar que, nesse caso, não se trata de morte "médica", mas com tiros de fuzilamento. Em seguida, os médicos constatavam se de fato as vítimas evoluíram ao óbito. ${ }^{129}$

No entanto, o mais problemático eram as situações em que um médico, fazendo uso de seus conhecimentos, sofisticava um método de morte para o Führer. Acredita-se que, em 1940, Hitler seguiu o conselho do Dr. Heyde a usar monóxido de carbono como gás para matar um grande número de pessoas. ${ }^{130}$ A sugestão foi acatada, levando em conta que as injeções letais não eram tão eficazes.

Em testemunho durante o julgamento de Nuremberg, o Dr. Karl Brandt depõe que no período de escolhas dos métodos ele foi inicialmente contra o uso do gás, pois esse método excluía das mortes qualquer "aura" de aproximação de uma conduta médica. Mais tarde descobriu que a morte por injeção levava mais tempo para ocorrer do que pelo gás, de modo que essa seria mais humana e, em tese, foi caracterizada um avanço para a Medicina, se é que se poderia se referir assim a essa sistemática "morte medicalizada". Além disso, os médicos seniores passavam a mensagem de morte aos médicos jovens, que eram obrigados a executar. Essa era a burocracia do sistema. ${ }^{131}$

Em Bradenburgo, um médico de 29 anos, Dr. Eberl, aprendeu a operar a câmara de gás. Outro médico, Dr. Aquilin Ullrich, de 26 anos, o auxiliava. Anos mais tarde, Ullrich testemunhou que essas tarefas não envolviam praticamente nenhum conhecimento médico. Ambos examinavam os pacientes nus na antessala da câmara de gás, procedimento que, segundo ele, intuía acalmar os doentes mentais, além de camuflar o extermínio humano. $\mathrm{Na}$ verdade, se fazia apenas uma checagem da pessoa a ser assassinada junto de sua ficha médica, para se certificar de que realmente as pessoas corretas eram conduzidas ao gás.

${ }^{129}$ GOLDHAGEN, D.J., Os Carrascos Voluntários de Hitler: o Povo Alemão e o Holocausto, São Paulo, Companhia das Letras, 1997, p. 279.

${ }^{130}$ LIFTON, R.J., op.cit., p. 71.

${ }^{131}$ LIFTON, R.J., op.cit., p. 72. 
Muitas vítimas eram enganadas pela farsa de que tomariam um banho e receberiam roupas novas. Aqueles que percebiam a realidade e se tornavam hostis eram conduzidos com violência física. No momento em que as portas eram fechadas, o mesmo médico que havia feito o exame era responsável por eliminar o ar de dentro da câmara. Durante dez minutos era lançado monóxido de carbono e seu efeito era observado por uma pequena janela. Assim que se constatavam as mortes, a câmara era aberta para entrada de ar fresco por meio de um ventilador e o gás, consequentemente, era forçado para a parte externa. Isso levava aproximadamente uma hora. Os cadáveres a serem dissecados eram levados para uma sala especial, porém a maioria terminavam nos famígeros fornos para serem queimados. $^{132}$

Após a execução das vítimas, o próximo passo desses médicos se pautava em falsificar um atestado de óbito de forma a relatar uma morte crível ao histórico das fichas médicas de cada um. Tudo era elaborado consistentemente para demonstrar que o "paciente" contraiu uma doença infecciosa, pneumonia, doenças cardíacas, pulmonares, cerebrais etc. A experiência médica era bem utilizada nessas falsificações e conformava o treinamento dos médicos mais jovens, que recebiam guias para inserir importantes detalhes na criação dessa farsa. Lifton diz que provavelmente a elaboração de atestados convincentes era a única atividade médica realizada. Deveria ser um procedimento perfeito, apesar da omissão da data do óbito e de algumas inconsistências que ocorriam, por exemplo, o caso de uma família que recebeu duas urnas com as cinzas, ou o da viúva que recebeu o laudo do marido atestando morte por apendicite, no entanto, o falecido já o havia removido. ${ }^{133}$

Segundo Goldhagen os médicos que executavam as vítimas (mentalmente doentes e fisicamente incapazes) eram "carrascos", pois configurava um trabalho de cirurgiões desapaixonados, que agiam com frieza e sem envolvimento. ${ }^{134}$

Os médicos também foram responsáveis pelo projeto de wild euthanasia, que consistia em matar as pessoas selecionadas lentamente, por meio de remédio, injeção, dieta especial (fome) etc. Isso trouxe um maior poder aos médicos, ao ponto de eles poderem eleger sozinhos se exterminariam apenas crianças, adultos ou ambos. Muitas vezes chegavam ordens do tipo "esses prisioneiros podem durar três meses, não mais". Muitos

\footnotetext{
${ }^{132}$ LIFTON, R.J., op.cit., pp. 73-74.

${ }^{133}$ LIFTON, R.J., op.cit., p. 74

${ }^{134}$ GOLDHAGEN, D.J., op.cit., p. 424.
} 
lidavam com sentimentos fortes de culpa, mas diziam a si mesmos que apenas cumpriam ordens. $^{135}$

Lifton entrevistou um médico identificado apenas por Dr. D., sob a alegação de que ao participar das instituições de mortes em massa sentia uma profunda decepção, pois gostaria de oferecer tratamento e melhora a alguns dos pacientes mentais. Não havia a possibilidade de desenvolver um tratamento individual, era apenas uma máquina de morte em massa. Ele nunca teve a ilusão de que realmente atuava em um trabalho médico e desabafa declarando que "Gostaria de trabalhar como médico e não como soldado". ${ }^{136}$

O Dr. D. fez uso de mecanismos psicológicos para lidar com suas obrigações com o III Reich. Ele transferia a responsabilidade para o Dr. Heyde, seu superior, alegando que não poderia responder por seus atos, pois ainda era um médico em formação. Além disso, justificava-se por meio do argumento de que sua atuação se tratava de uma "busca da ciência", porque a cada morte ele estudava os cérebros a fim de aprender algo novo sobre a mente humana. Chegou ao ponto de inventar para si mesmo um cenário de pesquisa médica, para demonstrar que seu trabalho teria alguma importância para a ciência e para a humanidade. $^{137}$

Os médicos submetidos a essas obrigações enfrentavam muito estresse, afinal nenhuma profissão humana exige como tarefa diária o extermínio de inúmeros indivíduos. Em seu relato, o Dr. R. (outro médico que pediu proteção de sua identidade), se sentia tão mal com o seu trabalho que sofreu um infarto e pediu afastamento de suas funções. $\mathrm{O}$ regime nazista não perseguia os médicos que, por uma inaptidão individual em conseguir matar, simplesmente não conseguiam executar com sucesso as atividades, no entanto, rapidamente o médico era substituído por alguém mais apto. As penalidades (punição, perda de posto) surgiam se o profissional se demonstrasse claramente contrário aos ideais perseguidos e às obrigações exigidas. ${ }^{138}$

O tratamento médico oferecido aos presos nos campos de concentração era precário. $\mathrm{Na}$ obra de Goldhagen é relatado que apenas mulheres não judias recebiam assistência médica e remédios, as judias eram examinadas somente em sua chegada, para evitar a irrupção de alguma epidemia. Não raro, as prisioneiras judias eram as primeiras a morrer. $^{139}$

\footnotetext{
${ }^{135}$ LIFTON, R.J., op.cit., pp. 97-98, 101-102.

${ }^{136}$ LIFTON, R.J., op.cit., p. 104.

${ }^{137}$ LIFTON, R.J., op.cit., p. 106.

${ }^{138}$ LIFTON, R.J., op.cit., p. 109.

${ }^{139}$ GOLDHAGEN, D.J., op.cit., p. 363.
} 
A partir daqui serão apresentados em sequência os médicos que se destacaram por auxiliar o regime em suas atrocidades.

O Dr. Karl Brandt, que além de criador do "programa de eutanásia" fazia parte da elite do Führer, estava envolvido com execução sistemática de idosos, loucos, doentes incuráveis, crianças deformadas, tanto mediante a injeção letal quanto pelo método do gás em "hospitais" e asilos, em síntese, era responsável pelo extermínio de todas as "bocas inúteis" da máquina de guerra alemã. Aos vinte anos aproximadamente, Brandt já se destacava como um talentoso cirurgião, sendo considerado uma autoridade em lesões da coluna e cabeça. Ele se juntou ao Partido Nazista em 1932, dois anos mais tarde, agora com 29 anos, se tornou o médico pessoal e da confiança de Hitler. ${ }^{140}$ O Dr. François Bayle, psicólogo francês que analisou Brandt na época do julgamento de Nuremberg, o descreveu como um homem ambicioso, com ganas de poder e responsável não apenas pelo "programa de eutanásia", mas também pelas experiências ocorridas nos campos de concentração. Apesar de apresentar um bom caráter, foi se entorpecendo aos poucos com as crueldades cometidas e não conseguiu discernir o mal causado pelas ideias nazistas. Seu lado "humano", caracterizado pela busca de uma morte mais branda, se perdeu em meio às atrocidades dos campos de concentração. Brandt era indispensável para a realização das matanças em massa e evoluiu de posto rapidamente, alcançando o mais alto escalão em 1944. Em 1948, foi julgado culpado por ter cometido crimes de guerra em Nuremberg e em junho do mesmo ano foi enforcado. ${ }^{141}$

O Dr. Werner Heyde, defensor das ideias nazistas desde muito jovem, se destacou como médico do III Reich. Formou-se psiquiatra e, por recomendação de um paciente, Theodor Eicke, comandante de Dachau, um campo de concentração, entrou para o Partido Nazista em 1933. Heyde foi convocado para auxiliar na criação de métodos que objetivavam institucionalizar a brutalidade física e psicológica dos campos de concentração. Por meio desse primeiro contato, Heyde se tornou médico para SS, logo capitão, em 1936, e posteriormente foi promovido a major, tenente coronel e coronel, em 1941, 1943 e 1945, respectivamente. Dentre as funções exercidas na SS, Heyde teve de criar uma divisão neuropsiquiátrica para pesquisar neurologia, problemas psiquiátricos e hereditariedade nos presos dos campos, conhecimentos esses de extrema importância para justificar as mortes com embasamento científico. Simultaneamente, ele ajudava a Gestapo em Berlim, aconselhando sobre métodos de tortura para obtenção de informações de

\footnotetext{
${ }^{140}$ LIFTON, R.J., op.cit., p. 114.

${ }^{141}$ LIFTON, R.J., op.cit., pp. 116-117.
} 
prisioneiros. Também desempenhou um papel importante em legitimar o "programa de eutanásia" e forjar os atestados de óbito de forma impecável, ensinando o ofício para os jovens médicos. Após a guerra, Heyde fugiu e com uma nova e falsa identidade, passou a viver como médico de esportes em Kiel. Devido as suas extravagâncias, começou a chamar a atenção, sendo reconhecido e preso. Em 1961, com todos os detalhes preparados para seu julgamento, foi encontrado morto em sua cela, cometeu suicídio. Há indícios de tendências psicóticas e sádicas na personalidade de Heyde. ${ }^{142}$

O Dr.Hermann Pfannmüller se assemelhava muito ao Dr. Heyde, juntou-se ao partido em 1933 e além de defender o "programa de eutanásia", matava crianças e adultos de fome. Mentalmente, foi considerado incapaz de ser julgado, em 1948, na Corte de Munique, por apresentar fortes tendências depressivas e sádicas, bem como uma consideração muito desumana sobre qualquer ser vivo, um exemplo clássico de médico transformado em assassino. ${ }^{143}$

O Professor Max de Crinis, austríaco, foi um importante consultor psiquiátrico do regime, provavelmente também auxiliou na construção do "programa de eutanásia". Cuidava do Hospital Charité, em Berlim, e quando conseguia, evitava que certas pessoas e crianças fossem levadas para os locais onde o "programa de eutanásia" era aplicado. Como professor da universidade e diretor do setor psiquiátrico ocultava seu envolvimento nesse programa. Foi o médico que diagnosticou o Mal de Parkinson em Hitler. Conseguia realizar bem seus dois papéis: o de acadêmico de Medicina e o de médico da SS. Em $1^{\circ}$ de maio de 1945, ele provocou sua própria morte engolindo cianureto. ${ }^{144}$

O Dr. Carl Schneider, também austríaco, foi descrito por profissionais que trabalharam com ele no "programa de eutanásia" como um psiquiatra com grande senso de "humanidade". Ele se juntou ao partido em 1932. Apesar de suas obrigações, buscava aliviar as dores dos pacientes esquizofrênicos em vez de enviá-los imediatamente para eutanásia. Deixava a esterilização e a morte como última opção e conseguia executar perfeitamente bem tanto o projeto de pesquisa sobre a mente humana com os cérebros dos executados quanto as funções impostas pelo programa. ${ }^{145}$

Por sua vez, o Dr. Irmfried Eberl, outro austríaco, juntou-se ao partido aos 21 anos de e foi um dos primeiros a testar a morte por câmara de gás. Auxiliava o Dr. Heyde a

\footnotetext{
${ }^{142}$ LIFTON, R.J., op.cit., pp. 118-119.

${ }^{143}$ LIFTON, R.J., op.cit., p. 120.

${ }^{144}$ LIFTON, R.J., op.cit., p. 121.

${ }^{145}$ LIFTON, R.J., op.cit., p. 122.
} 
elaborar histórias consistentes de causas de morte. Aos 32 anos foi promovido de encarregado pela câmara de gás a comandante de um campo de morte, trazendo a ideia de que mais médicos poderiam chefiar outros campos. Era muito determinado nas matanças e chegava a usar jaleco nos campos de concentração. No entanto, não soube organizar o sistema, deixando cadáveres expostos, fato que gerou desespero a todos os recém-chegados e culminou em caos e desordem, sendo dispensado de seu dever. Apesar disso tudo, demonstrou-se como um dos grandes exemplos de médico que abraçou a ideologia nazista. $^{146}$

A Dra. Herta Oberheuser matava crianças com injeções de óleo e evipan (barbitúrico), para depois remover seus membros e órgãos vitais. $\mathrm{O}$ período compreendido entre a aplicação da seringa e a morte era de três a cinco minutos, com a pessoa consciente durante todo o procedimento. Além disso, realizava experimentos dolorosos com presos. Simulava ferimentos de guerra esfregando pedaços de madeira, pregos enferrujados, cacos de vidro, poeira e terra dentro das feridas, a fim de adquirir a mesma experiência dos combatentes alemães e desenvolver melhorias para eles. ${ }^{147}$

O Dr. Carl Clauberg, professor e pesquisador em Ginecologia, foi um médico do regime que gostava de realizar experimentos de esterilização para o governo, porém seguindo suas próprias ideias. Em Auschwitz, ele injetava substâncias químicas nos ventres de mulheres judias e ciganas, o que causava dores horríveis, ovários inflamados, espasmos violentos no estômago e sangramento. Tanto homens quanto mulheres eram posicionados por muitos minutos em máquinas de raios-x direcionados aos seus órgãos sexuais. A maioria dos sujeitos dessas "pesquisas" morria ou era levada para a câmara de gás, já que suas queimaduras da radiação os impediam de poder trabalhar nos campos. Os testículos de muitas vítimas foram levados para Breslau para exame histopatológico. Era frio e faziam-se piadas cruéis. Clauberg acabou sendo capturado pelos russos em 1945, condenado por crimes de guerra e sentenciado a 25 anos de prisão. No entanto, em 1953, com a morte de Stálin conseguiu a liberdade por meio de acordos diplomáticos e foi repatriado. Declarou para a imprensa seus grandes feitos em esterilização. No ano de 1955, os sobreviventes pressionaram e Clauberg foi preso em novembro. Após muita insistência, finalmente, a Câmara Alemã de Medicina revogou sua licença médica. Em 9 de agosto de

\footnotetext{
${ }^{146}$ LIFTON, R.J., op.cit., p. 124.

${ }^{147}$ Site do Museu do Holocausto dos Estados Unidos. Disponível em:

$<$ http://www.auschwitz.dk/doctors.htm>. Acesso em: 21 jun. 2011.
} 
1957, Clauberg foi encontrado morto em sua cela, por circunstâncias misteriosas, pouco antes do início de seu julgamento. ${ }^{148}$

Por fim, o mais notório dos médicos nazistas, o Dr. Josef Mengele, também conhecido como "o anjo da morte". Estudou na Universidade de Munique, sua posição política era de extrema direita, e se juntou ao Partido Nazista ainda muito jovem, em 1937. Também estudou nas universidades de Bonn, Viena e Frankfurt, sendo muito interessado nos estudos sobre genética, herança biológica e higiene racial. Escreveu estudos sobre o tamanho do maxilar de quatro diferentes etnias. ${ }^{149}$ Mengele estava destinado a se dedicar a uma carreira acadêmica, no entanto, sua carreira militar tornou-se mais relevante e ele conquistou muitas medalhas. Foi ferido em combate e designado para cuidar de um campo de concentração. Em 1943 e aos 32 anos, chegou em Auschwitz, a pedido dele, pois o local apresentava muito potencial para seus estudos. Ele era obcecado especialmente pelos gêmeos e pela seleção das pessoas fosse para experimentos, fosse para a eutanásia, e, segundo relatos de testemunhas, estava presente em quase todos os experimentos realizados, desde a câmara de gás até os fornos. ${ }^{150}$ Muitos o descreviam como "agressivo e cruel, porém da forma mais cavalheira que existe". Fazia o que queria e tinha convicção de que fazia a "coisa certa". Venerava a eficiência e prezava o fato de não haver filas muito longas para as injeções letais, discutindo com os médicos e exibindo a maneira mais ligeira de aplicar a seringa.

Os experimentos com gêmeos de Mengele eram resquícios de seus estudos na Universidade de Frankfurt. Havia a vontade de desvendar a base genética da suposta "raça superior", para tanto existiam três locais específicos e separados para as pesquisas com gêmeos, fossem idênticos ou não. Os primeiros eram analisados comparativamente em detalhes, desejavam saber sobre o histórico de doenças na família e retiravam muito sangue para análise. Os gêmeos eram normalmente crianças ou adolescentes. Mengele gostava de fazer tudo e havia separado uma sala especial de patologia, para analisar os gêmeos que morriam. O Dr. Miklos Nyiszli, que ajudava Mengele nessa sala, testemunhou em 1945 alegando que Mengele era o assassino direto de cada gêmeo. ${ }^{151}$ Ele os analisava em vida e quando esgotava os conhecimentos matava cada um com injeções letais para aprender mais na dissecção. Muitas vezes, se um dos gêmeos morria em decorrência dos experimentos,

\footnotetext{
${ }^{148}$ LIFTON, R.J., op.cit., p. 273.

${ }^{149}$ LIFTON, R.J., op.cit., p. 339.

${ }^{150}$ LIFTON, R.J., op.cit., p. 342.

${ }^{151}$ LIFTON, R.J., op.cit., p. 350.
} 
ele assassinava o outro para realizar o estudo comparativo na autópsia. Também queria descobrir um procedimento para colorir a íris de crianças na cor azul. Muitos cadáveres de gêmeos eram encontrados com a retina manchada de azul. ${ }^{152}$ Uma testemunha relata sobre o sadismo de Mengele e sobre o fato de ele ter conhecimentos de psicologia, pois sua atuação era considerada uma forma de tortura psicológica e física. ${ }^{153}$ Ele personificava a distorção do papel do médico que em vez de buscar a cura, queria alcançar a morte.

O Dr. Eduard Wirths recomendou Mengele para trabalhar em Auschwitz, fato que o fazia sentir-se muito culpado, tanto que testemunhou contra Mengele na Corte de Frankfurt. Alguns anos mais tarde, diante do sentimento de culpa, Wirths se suicidou. Mengele foi indiciado por crimes hediondos e dolosos, dentre eles, a seleção de pessoas, a aplicação de soluções letais, o uso de armas de tiro e da violência física, além de outras formas de assassinato doloso. ${ }^{154}$ Apesar de todos esses crimes, ao final da guerra, Mengele conseguiu fugir e viveu por mais de 35 anos em países como Paraguai e Brasil, sendo escondido por simpatizantes de ideias nazistas. Alega-se que ele morava no Brasil e que morreu afogado no mar, após sofrer um derrame em 1979.

Em outubro de 1946 até agosto de 1947 se deu o Tribunal de Nuremberg para julgar os médicos envolvidos nos diversos crimes hediondos referidos até então. Vinte e três médicos foram acusados de conduzir tratamento vil e cruel, bem como experimentos potencialmente letais em prisioneiros dos campos de concentração nos anos de 1933 a 1945.

Dentre os experimentos realizados, cita-se a resistência a altitudes, que consistia em deixar o sujeito da pesquisa em uma câmara de baixa pressão e logo simular uma subida de altitude, efeito que gerou muitas mortes. Os testes com os efeitos de bombas incendiárias feitas de fósforo e cujo resultado era queimaduras gravíssimas e dolorosas e, por fim, a morte. Também foram realizados experimentos de congelamento, para verificar os efeitos de hipotermia. Os sujeitos eram colocados em um tanque de gelo por três horas, onde praticamente todos morriam ou perdiam algum membro. Em um intento para provar que a água do mar era potável, os indivíduos eram privados de comida e alimentados unicamente por água salgada quimicamente processada, resultando em muita dor e lesões permanentes às vítimas. Também foram conduzidas experiências sobre a imunidade e o tratamento da malária. Os sujeitos eram infectados com injeções das mucosas dos mosquitos, após

\footnotetext{
${ }^{152}$ LIFTON, R.J., op.cit., p. 362.

${ }^{153}$ LIFTON, R.J., op.cit., p. 374.

${ }^{154}$ LIFTON, R.J., op.cit., p. 341.
} 
adquirirem a doença, eram tratados com drogas variadas. Mais de mil pessoas foram usadas nesse experimento; a maioria morreu e outros ficaram com alguma lesão permanente. Os efeitos e o tratamento do gás mostarda constituíram outra pesquisa, nela os indivíduos eram feridos e, em seguida, jogava-se o gás. Muitos morreram, outros sofreram dor intensa e ficaram com algum tipo de sequela. Com esse mesmo sentido, machucavam presos e infectavam as feridas com bactérias, por exemplo, streptococcus, gangrena gasosa e tétano. Interrompia-se a circulação do sangue com um garrote para simular um ferimento de guerra. A infecção era potencializada por meio de pedaços de madeira e vidro dentro das feridas, tratadas com sulfanilamida e outras drogas, para verificar a eficiência delas. Muitos morreram ou sofreram intensa dor e agonia. Ademais, para constatar o tratamento de tifo, muitos sujeitos eram infectados e não tratados, de modo a observar empiricamente a evolução da doença e a persistência do vírus, nesse tipo de experiência mais de $90 \%$ das vítimas morreram. Por fim, fizeram experimentos com veneno secretamente colocado na comida dos presos, que morriam ou eram mortos intencionalmente para serem examinados em autópsia. ${ }^{155}$

Como resultado dos julgamentos, 15 dos acusados foram considerados culpados e oito foram inocentados. Dos 15 , sete foram condenados à pena de morte e o restante à prisão. A Dra. Herta Oberheuser, mencionada anteriormente, era a única mulher envolvida e recebeu pena de 20 anos de prisão. Liberada em 1952, se tornou médica de família. Teve sua licença revogada em 1958. Os juízes eram todos norte-americanos. ${ }^{156}$

As atrocidades nos campos de concentração representam uma amostra das potencialidades malignas que a atividade médica pode provocar. Uma política de "governo antes do indivíduo". Os referidos acontecimentos foram denominados pelo Dr. Robert J. Lifton a "ponte médica para o genocídio". Havia uma sensação de que as mortes ordenadas e, especialmente, aprovadas por um médico, constituíam mortes justificadas e científicas. ${ }^{157}$ Ele também usa o termo "institucionalização da morte médica", para fins de controle de doenças que a nação germânica não iria tolerar. Eram entendidas como as "mortes apropriadas", já que decretadas por um médico. ${ }^{158}$ Nos julgamentos muitos médicos alegaram que suas condutas não poderiam ser reconhecidas como delituosas pelo

\footnotetext{
${ }^{155}$ Site do Museu do Holocausto dos Estados Unidos. Disponível em:

$<$ http://www.auschwitz.dk/doctors.htm>. Acesso em: 22 jun. 2011.

${ }^{156}$ Site de Harvard Law School Library. Disponível em:

$<$ http://nuremberg.law.harvard.edu/php/docs_swi.php?DI=1\&text=medical $>$. Acesso em: 12 jan. 2012.

${ }^{157}$ LIFTON, R.J., op.cit., p. 139.

${ }^{158}$ LIFTON, R.J., op.cit., p. 148 e 151.
} 
simples fato de não existir tipificação na legislação da época. No entanto, as violações cometidas ao Juramento Hipocrático se justificavam por si só. Contra esse argumento, muitos médicos alegaram que o juramento realizado para Hitler era superior ao de Hipócrates e que um indivíduo simplesmente não poderia ser julgado por ter obedecido ordens de um superior. ${ }^{159}$

De acordo com Shmuel P. Reis, as mortes durante a Segunda Guerra Mundial não teriam um número tão elevado se não fosse pelo esforço individual de cada médico e pela organização da própria profissão "Medicina". Ambos representaram um papel que permitiu que as ideias nazistas fossem levadas às últimas consequências. E, em razão desse período de trevas na Medicina, isso criaria um imperativo educacional para as gerações subsequentes, em que cada médico se torna capaz de impedir e evitar esses comportamentos. ${ }^{160}$

A modo de um parêntese, na obra da filósofa Hannah Arendt, Eichmann em Jerusalém - Um relato sobre a banalidade do mal, escrita após o julgamento de Adolf Eichmann em Jerusalém, em 1960, como correspondente da revista The New Yorker, temse a cunhagem do termo "banalidade do mal", ou seja, a expectativa desse julgamento era a descoberta de um monstro capaz de incríveis barbaridades. No entanto, se percebeu um homem comum, não muito inteligente, sem personalidade, um mero funcionário público, que também alegou:

Com o assassinato dos judeus não tive nada a ver. Nunca matei um judeu, nem um não judeu - nunca matei nenhum ser humano. Nunca dei uma ordem para matar fosse um judeu fosse um não judeu; simplesmente não fiz isso. ${ }^{161}$

Eichmann simplesmente alegava obediência às ordens de seus superiores, de modo que se sua culpa provinha da obediência tal fato devia ser louvado como uma virtude, da qual os líderes nazistas abusaram. Ele havia sido uma vítima do sistema, de modo que somente os líderes mereciam punição. "Não sou o monstro que fazem de mim, mas a vítima de uma falácia". ${ }^{162}$

\footnotetext{
${ }^{159}$ LIFTON, R.J., op.cit., p. 207.

${ }^{160}$ REIS, S.P.; WALD, H.S., "Learning From the Past: Medicine and the Holocaust", The Lancet, v. 374, Issue 9684, 11 July 2009, p. 111. Disponível em:

$<$ http://www.thelancet.com/journals/lancet/article/PIIS0140-6736(09)61275-7/fulltext>. Acesso em: 12 jul. 2011.

${ }^{161}$ ARENDT, H., Eichmann em Jerusalém - um Relato sobre a Banalidade do Mal, 10ª reimp., São Paulo, Companhia das Letras, 2010, p. 33.

${ }^{162}$ ARENDT, H., op.cit., p. 269.
} 
Eichmann terminou condenado à morte e sua sentença executada de forma extraordinariamente veloz. Hannah Arendt comenta ao fim do julgamento:

Eles sabiam, é claro, que teria sido realmente muito reconfortante acreditar que Eichmann era um monstro; se assim fosse, a acusação de Israel contra ele teria soçobrado ou no mínimo, perdido todo o interesse. Não é possível convocar o mundo inteiro e reunir correspondentes dos quatro cantos da Terra para expor o Barba Azul no banco dos réus. O problema com Eichmann era exatamente que muitos eram como ele, e muitos não eram nem pervertidos, nem sádicos, mas eram e ainda são terríveis e assustadoramente normais. Do ponto de vista de nossas instituições e de nossos padrões morais de julgamento, essa normalidade era muito mais apavorante do que todas as atrocidades juntas, pois implicava que - como foi dito insistentemente em Nuremberg pelos acusados e seus advogados - esse era um tipo novo de criminoso, efetivamente hostis generis humani, que comete seus crimes em circunstâncias que tornam praticamente impossível para ele saber ou sentir que está agindo de modo errado. ${ }^{163}$

Esse argumento junto da obediência a "ordens superiores" mostrava ao mundo a capacidade humana influída por certas circunstâncias excepcionais. Assim, Arendt criou a expressão "banalidade do mal" para indicar que alguns indivíduos agem dentro das regras do sistema a que pertencem sem racionalizar sobre seus atos. Eles não se preocupam com as consequências, apenas com o cumprimento das ordens. A tortura, a execução de seres humanos ou a prática de atos do "mal" não são racionalizados em seu resultado final, desde que as ordens para executá-los advenham de instâncias superiores e que exista ao final do dia uma sensação de "trabalho cumprido". Eichmann era normal, pretendia ser bemsucedido, mas parecia não ter a ciência de que matar pessoas em massa, mesmo indiretamente, era errado. Ele não possuía nenhum distúrbio ou desvio de personalidade.

Segue um trecho dos termos da sentença:

Felizmente não precisamos ir tão longe. Você próprio não alegou a efetiva, mas apenas a potencial culpa da parte de todos que vivem num Estado cujo principal propósito político se tornou a perpetração de crimes inauditos. $\mathrm{E}$ a despeito das vicissitudes exteriores ou interiores que o levaram a se transformar em criminoso, existe um abismo entre a realidade do que você fez e a potencialidade dos que os outros poderiam ter feito. Nós nos ocupamos aqui apenas com o que você fez, e não com a natureza possivelmente não criminosa de sua vida interior e de seus motivos ou com as potencialidades criminosas daqueles à sua volta. Você contou sua história como uma história de dificuldades e, sabendo das circunstâncias, estamos até certo ponto dispostos a admitir que em circunstâncias mais favoráveis é altamente improvável que você tivesse de comparecer perante nós ou perante qualquer outra Corte criminal. Suponhamos, hipoteticamente, que foi simplesmente a má sorte que fez de você um instrumento da organização do assassinato em

${ }^{163}$ ARENDT, H., op.cit., p. 299. 
massa; mesmo assim resta o fato de você ter executado, e portanto apoiado ativamente, uma política de assassinato em massa. Pois política não é um jardim de infância; em política, obediência e apoio são a mesma coisa. E, assim como você apoiou e executou uma política de não partilhar a Terra com o povo judeu e com o povo de diversas outras nações - como se você e seus superiores tivessem o direito de determinar quem devia e quem não devia habitar o mundo -, consideramos que ninguém, isto é, nenhum membro da raça humana, haverá de querer partilhar a Terra com você. Esta é a razão, e a única razão, pela qual você deve morrer na forca. ${ }^{164}$

Dessa forma, fica claro que as alegações de Eichmann não o eximiram de culpa fato exemplar para a análise de determinados comportamentos médicos no próximo capítulo.

Feita a digressão, retornemos à Nuremberg. Após o veredito dos médicos, em 1947, foi elaborado um documento conhecido como Código de Nuremberg. Conforme mencionado, os médicos indiciados alegaram que os abusos ocorridos em pesquisas ao longo de séculos antes da Segunda Guerra Mundial nunca haviam sido criminalizados e punidos, além de não haver leis para regulamentar e diferenciar, até aquela ocasião, o legal do ilegal, impossibilitando o julgamento desses profissionais. Diante disso, médicos estadunidenses se uniram e criaram esse Código com intuito de subsidiar os juízes de Nuremberg para determinação de que o ocorrido nos campos de concentração foram crimes contra humanidade.

O Código apresentava dez pontos, quais sejam:

1. O consentimento voluntário do ser humano é absolutamente essencial. Isso significa que as pessoas que serão submetidas ao experimento devem ser legalmente capazes de dar consentimento; essas pessoas devem exercer o livre direito de escolha sem qualquer intervenção de elementos de força, fraude, mentira, coação, astúcia ou outra forma de restrição posterior; devem ter conhecimento suficiente do assunto em estudo para tomarem uma decisão. Esse último aspecto exige que sejam explicados às pessoas a natureza, a duração e o propósito do experimento; os métodos segundo os quais será conduzido; as inconveniências e os riscos esperados; os efeitos sobre a saúde ou sobre a pessoa do participante, que eventualmente possam ocorrer, devido à sua participação no experimento. $\mathrm{O}$ dever e a responsabilidade de garantir a qualidade do consentimento repousam sobre o pesquisador que inicia ou dirige um experimento ou se compromete nele. São deveres e responsabilidades pessoais que não podem ser delegados a outrem impunemente.

2. O experimento deve ser tal que produza resultados vantajosos para a sociedade, que não possam ser buscados por outros métodos de estudo, mas não podem ser feitos de maneira casuística ou desnecessariamente.

3. O experimento deve ser baseado em resultados de experimentação em animais e no conhecimento da evolução da doença ou outros problemas em estudo; dessa maneira, os resultados já conhecidos justificam a condição do experimento.

${ }^{164}$ ARENDT, H., op.cit., pp. 301-302. 
4. O experimento deve ser conduzido de maneira a evitar todo sofrimento e danos desnecessários, quer físicos, quer materiais.

5. Não deve ser conduzido qualquer experimento quando existirem razões para acreditar que pode ocorrer morte ou invalidez permanente; exceto, talvez, quando o próprio médico pesquisador se submeter ao experimento.

6. O grau de risco aceitável deve ser limitado pela importância do problema que o pesquisador se propõe a resolver.

7. Devem ser tomados cuidados especiais para proteger o participante do experimento de qualquer possibilidade de dano, invalidez ou morte, mesmo que remota.

8. O experimento deve ser conduzido apenas por pessoas cientificamente qualificadas.

9. O participante do experimento deve ter a liberdade de se retirar no decorrer do experimento.

10. O pesquisador deve estar preparado para suspender os procedimentos experimentais em qualquer estágio, se ele tiver motivos razoáveis para acreditar que a continuação do experimento provavelmente causará dano, invalidez ou morte para os participantes. ${ }^{165}$

Da leitura desses dez pontos, percebe-se que o que ocorreu durante a Segunda Guerra Mundial foi praticamente o oposto, justamente por visualizar os seres humanos como meios de se atingir fins e não como indivíduos, abandonando completamente a preocupação maior, ou seja, o bem-estar, a integridade física e psíquica.

Indubitavelmente, o Código de Nuremberg atraiu a atenção universal para a necessidade de se pensar em diretrizes relacionadas à pesquisa envolvendo seres humanos, em especial, o respeito à autonomia, aspecto nunca estabelecido em momentos anteriores. No entanto, a força legal de tal documento não foi estabelecida e incorporada imediatamente pelas leis americanas e alemãs, isso só passou a integrar a relação médicopaciente nas décadas de 1960 e 1970, com a Declaração de Helsinki, redigida em 1964, na $18^{\mathrm{a}}$ Assembleia da Associação Médica Mundial. Esse Código norteou as diretrizes seguintes, de modo que a pesquisa científica envolvendo seres humanos, em vista da necessidade de sua continuidade e absorção das inovações tecnológicas e científicas, passou a ser constantemente revisada e vigiada, cuja finalidade é o impedimento de possíveis abusos.

\footnotetext{
${ }^{165}$ GOLDIM, J.R., Código de Nuremberg. Disponível em: $<$ http://www.ufrgs.br/bioetica/nuremcod.htm>.
} Acesso em: 22 jun. 2011. 
A Associação Médica Mundial, fundada em 17 de setembro de 1947, quando médicos de 27 países se encontraram na primeira Assembleia Geral, em Paris, é uma organização internacional que representa os médicos. Os fundadores, cientes dos abusos cometidos antes e após a guerra decidiram tornar muito claro para os médicos suas respectivas obrigações éticas. A Associação é uma confederação de associações livres profissionais, sustentada por contribuições anuais de seus membros, que inclui atualmente noventa e cinco Associações Médicas Nacionais. ${ }^{166}$

O Instituto Max Planck na Alemanha tem realizado inúmeras pesquisas para documentar, publicizar e pedir desculpas pelos feitos de seus antecessores durante a Segunda Guerra Mundial. Nesse mesmo esforço, as universidades de Tübingen, Viena e Jena investigam a exploração dos cadáveres das vítimas do Holocausto por meio de seus institutos de anatomia. Portanto, um fato histórico e atroz ocorrido há mais de cinquenta anos ainda repercute na vida dos novos estudantes de Medicina e deve servir de lição, a fim de que os abusos prossigam apenas nas páginas dos livros de História. ${ }^{167}$

Infelizmente, conforme mencionado, os ideais do Código de Nuremberg não foram imediatamente obedecidos, é possível citar os abusos contra os negros no tratamento da sífilis nos Estados Unidos ou contra as comunidades indígenas ao redor do mundo ao longo de muitas décadas. Aparentemente, nos dias atuais há um respeito e obediência à autonomia de todo e qualquer sujeito de pesquisa.

As lições aprendidas sobre o poder ilimitado nas mãos dos médicos naquele momento histórico foram devidamente consertadas por meio da criação de aparatos legais, em especial, para evitar abusos em pesquisas com seres humanos. Resta, agora, investigar se as aptidões de um médico, apesar de não mais utilizadas em pesquisas cruéis com seres humanos, não são empregadas no desenvolvimento de técnicas eficazes de interrogatório ou, até mesmo, no uso da força física e psicológica como castigo ou para obtenção de informações, questões que serão discutidas no próximo capítulo.

\footnotetext{
${ }^{166}$ Site da Associação Médica Mundial. Disponível em: <http://www.wma.net/en/60about/index.html>. Acesso em: 30 jun. 2011.

${ }^{167}$ REIS, S.P.; WEINBERG, U., “Medicine's Dark Past”, Student BMJ, v. 14, February 2006, p. 46. Disponível em: $<$ http://archive.student.bmj.com/issues/06/02/editorials/46.php $>$. Acesso em: 12 jul. 2011.
} 


\section{V - O ENVOLVIMENTO MÉDICO COM TORTURA NA ATUALIDADE}

\section{a) Conceito de tortura}

Segundo Giovanni Maio, a tortura, além de ser uma realidade em nossos dias, se torna cada vez mais científica em razão do auxílio e da cumplicidade de profissionais de Medicina. O estudo da função original da tortura pode esclarecer os motivos que propiciaram a participação dos médicos nessa prática, como eles a enxergavam e o que ela representa hoje. ${ }^{168}$ São celebrados aniversários de declarações antitortura, mas torturadores ainda existem.

Utilizada como método de coerção de testemunhas em procedimentos judiciais, pensava-se que a tortura era a única forma de se obter a verdade de escravos, e que constituía um meio de distingui-los dos homens livres, pois fixava os limites da sociedade dessa época. Se um indivíduo perdesse o status de homem livre ele poderia ser torturado, fato que justifica o medo das pessoas em serem escravizadas. Assim, a tortura era um instrumento opressivo para preservação do poder, visão que ainda pode ser relacionada ao período contemporâneo. ${ }^{169}$

$\mathrm{Na}$ Grécia e Roma Antiga, os filósofos questionavam a fidedignidade das informações obtidas mediante a tortura, mas não a aboliam. Isso se explica mais por uma questão cultural que, além de considerar a escravidão um processo comum, não dissociava a dualidade escravo/tortura. A partir da origem do Cristianismo e da noção de igualdade entre as pessoas, essa prática foi perdendo sua importância. No século VI, de acordo com a decisão do Papa Gregório, o Grande, um testemunho obtido por tortura não era válido, fato que extinguiu a tortura na Europa por um longo período. ${ }^{170}$

Entretanto, na Idade Média, especialmente durante a Inquisição, retomou-se a tortura como uma prática judicial embasada, inclusive, pelo sistema judicial romano canônico, segundo o qual para condenar alguém era necessária uma evidência sólida ou uma confissão. Na Grécia antiga, uma confissão só era fidedigna se obtida por meio de

\footnotetext{
${ }^{168}$ MAIO, G., "History of medical involvement in torture - then and now", The Lancet, v. 357, Issue 9268, 19 May 2001, pp. 1609-1611. Disponível em: $<$ http://www.thelancet.com/journals/lancet/article/PIIS01406736(00)04729-2/fulltext>. Acesso em: 12 jul. 2011.

${ }^{169}$ MAIO, G., op.cit., p. 1609.

${ }^{170}$ MAIO, G., op.cit., p. 1609.
} 
tortura, desse modo, em qualquer delito em que não existia uma prova, empregava-se essa prática até se obter a confissão. Era uma atitude aceita pela ordem social da época. ${ }^{171}$

A permanência da tortura ao longo do tempo se explica justamente por essa associação com direito e poder. Para Michel Foucault, o conceito em estudo une prova da verdade e demonstração de poder. Até o século XVIII, a tortura se enquadrava em um sistema legal em que acusação, condenação e sentença eram originários direta ou indiretamente de uma soberania. Considerava-se o ato criminoso um ataque à pessoa de soberania, por isso muitas penas cruéis eram expostas como exemplo à população e podiam ser vistas como uma "restauração da autoridade momentaneamente ferida". Assim, poder e tortura estavam intrinsecamente relacionados, um poder ameaçado levava à tortura. $^{172}$

Para adentrar efetivamente no tópico "O envolvimento médico com tortura na atualidade", é essencial aclarar o significado do conceito "tortura" e observar qual definição determina os comportamentos que devem se enquadrar para não existir a possibilidade de alguma conduta ser confundida ou maliciosamente afastada. Conforme a definição da Convenção Contra a Tortura e Outros Tratamentos ou Penas Cruéis, Desumanos ou Degradantes (1984) da ONU:

Artigo $1^{\circ}$ - Para fins da presente Convenção, o termo "tortura" designa qualquer ato pelo qual dores ou sofrimentos agudos, físicos ou mentais, são infligidos intencionalmente a uma pessoa a fim de obter, dela ou de terceira pessoa, informações ou confissões; de castigá-la por ato que ela ou terceira pessoa tenha cometido ou seja suspeita de ter cometido; de intimidar ou coagir esta pessoa ou outras pessoas; ou por qualquer motivo baseado em discriminação de qualquer natureza; quando tais dores ou sofrimentos são infligidos por um funcionário público ou outra pessoa no exercício de funções públicas, ou por sua instigação, ou com o seu consentimento ou aquiescência. Não se considerará como tortura as dores ou sofrimentos que sejam consequência unicamente de sanções legítimas, ou que sejam inerentes a tais sanções ou delas decorram. ${ }^{173}$

Dessa forma, os atos que consistem em tortura são: infligir dor deliberada ou sofrimento severo, físico ou mental a um indivíduo a fim de obter informações.

A Declaração de Tóquio, estabelecida pela Associação Médica Mundial em 1975, além de mencionar o envolvimento médico com tortura, emprega uma definição mais

\footnotetext{
${ }^{171}$ MAIO, G., op.cit., p. 1609.

${ }^{172}$ MAIO, G., op.cit., p. 1610.

${ }^{173}$ Site da ONU. Disponível em: < http://www.un.org/documents/ga/res/39/a39r046.htm>. Acesso em: 12 jul. 2011.
} 
sucinta e menos legalista do que a da ONU, em outras palavras, omite a questão da severidade e do sofrimento, mas inclui os elementos da tortura supracitados:

Para efeitos da presente Declaração, a tortura é definida como a imposição deliberada, sistemática ou devassa de sofrimento físico ou mental por uma ou mais pessoas agindo sozinho ou sob as ordens de qualquer autoridade, para forçar outra pessoa para produzir informação, fazer uma confissão, ou por qualquer outro motivo. ${ }^{174}$

Entende-se que para ser justo, não se deve limitar a noção do que pode ou não ser considerado tortura, a simples presença dos elementos referidos constituem motivos suficientes para deflagrá-la. O Dr. James Welsh, coordenador do Programa Médico da Anistia Internacional, entende que o estupro e outros modos de violência contra a mulher também são uma forma de tortura e, mesmo quando um ente governamental não está envolvido, o governo tem a obrigação de proteger seus cidadãos desses abusos. ${ }^{175}$ Portanto, a tortura está longe de ser pensada como um tipo penal fechado. Para Welsh, ela pode ser executada para obter informações e confissões, para forçar a colaboração, a cooperação e a mudança de crenças, para disciplinar e punir indivíduos, para "limpeza étnica", para espalhar o terror na comunidade, para o enriquecimento por meio de suborno das vítimas ou simplesmente como um ato aleatório de sadismo. ${ }^{176}$

De acordo com os objetivos deste trabalho não será discutida a legitimidade do emprego da tortura. O pensamento a ser seguido é o de que a a tortura não deve ser utilizada em hipótese alguma.

Michael Peel, Noam Lubell e Jonathan Beynom, três médicos, elaboraram um manual específico aos profissionais de saúde que discorre sobre como investigar e documentar a tortura. Segundo a obra, a proibição da tortura não se restringe apenas aos países que ratificaram tratados específicos, mas trata-se de uma norma de Direito Internacional comum a todos os Estados, mesmo sem a ratificação de um tratado. A proibição da tortura adquire status de "norma peremptória" do Direito Internacional e os

\footnotetext{
${ }^{174}$ Site da Associação Médica Mundial. Disponível em: $<$ http://translate.googleusercontent.com/translate_c?hl=ptBR\&langpair $=$ en $\% 7 \mathrm{Cpt \& rurl=translate.google.com}$. br\&u=http://www.wma.net/en/30publications/10policies /c18/index.html\&usg=ALkJrhj1WJBzwyp-5VVUNDHaGPcZXVm_hQ>. Acesso em: 06 jul. 2011.

${ }^{175}$ WELSH, J., "The Problem of Torture”, In: The Medical Documentation of Torture, Edited by Michael Peel and Vicent Iacopino, New York, Cambridge University Press, 2009, p. 3.

${ }^{176}$ WELSH, J., op.cit., p. 5.
} 
Estados não têm a opção de desconsiderá-la ou derrogá-la. ${ }^{177}$ Portanto, não há justificativa legal, geográfica, temporal que admita a tortura. Nesse sentido, o manual ainda determina que:

\begin{abstract}
A tortura é uma prática proibida em todos os sistemas jurídicos, mas que continua sendo disseminada pelo mundo, algumas vezes disfarçada pelo uso de termos ludibriosos, como 'stress and duress' (técnicas violentas de interrogatório) ou interrogatório coercivo. ${ }^{178}$
\end{abstract}

É sabido que a Administração de George W. Bush provocou uma inquietação no que se refere à noção de tortura, especialmente, ao trazer determinadas condutas, por exemplo, as "tentativas legítimas de interrogatório na obtenção de informação indispensável na guerra contra o terror”. Esse assunto será tratado com mais ênfase posteriormente, a partir do estudo do caso ocorrido nos Estados Unidos a respeito do papel do médico que resolveu servir às Forças Armadas. É importante, no entanto, não se enganar em relação ao fato de que em qualquer país, em circunstâncias especiais, muitos médicos poderiam participar dessa prática errônea e desumana.

\title{
b) Médicos e a tortura
}

Uma das primeiras referências de cumplicidade médica e tortura na história data do século XVI, quando Carlos V, da Espanha, pediu aos seus médicos para descobrirem se os réus conseguiriam suportar uma sessão de tortura. A primeira referência oficial está na "Constitutio Criminalis Carolina" de 1532, em que foi codificada a presença médica na tortura.

O médico atuava principalmente para fins jurídicos e devia respeitar as categorias de pessoas proibidas de serem sujeitos de tortura, a saber: os cegos, os mudos, os aleijados, os loucos e os doentes. Portanto, além de providenciarem um certificado sobre a saúde física e mental do acusado, os médicos deviam atestar se ele suportaria a tortura. No início do século XVIII, a maioria dos países europeus exigia por lei esse certificado médico. $\mathrm{Na}$

\footnotetext{
177 PEEL, M.; LUBELL, N.; BEYNON, J. Investigação Médica e Documentação sobre Tortura - Manual para Profissionais de Saúde, $1^{\mathrm{a}}$ ed., Centro de Direitos Humanos, Universidade de Essex, Grã-Bretanha, 2005, p. 17. Disponível em:

$<$ http://www.dhnet.org.br/denunciar/tortura/index.htm>. Acesso em: 02 nov. 2009.

${ }^{178}$ PEEL, M.; LUBELL, N.; BEYNON, J., op.cit., p. 13.
} 
Itália, era necessário o parecer de dois médicos. As parteiras eram quem examinavam as grávidas para afastá-las plenamente da tortura. ${ }^{179}$

O profissional de Medicina era um conselheiro da tortura, se o acusado estava doente ou fraco cabia a ele determinar quais métodos não o matariam. Os médicos da tortura, como eram chamados no século XVI, aconselhavam antes e durante a sessão de tortura, na qual eram responsáveis por observar e advertir o momento em que a sessão deveria terminar para evitar uma morte súbita. Além disso, saberiam afirmar se o acusado inconsciente estava fingindo ou não, e curavam os ferimentos para que a sessão de tortura pudesse prosseguir. ${ }^{180}$

Steven H. Miles ao mencionar Cesare Beccaria em sua obra Dos delitos e das penas, de 1764, mostra que nessa época já se tinha a noção de que sob tortura um homem inocente pode confessar um crime que não cometeu. ${ }^{181}$

É importante ressaltar que ao longo da história o papel dos médicos na torturafoi sempre passivo. Eles aconselhavam e curavam, mas não executavam os métodos nem criavam sugestões de aperfeiçoamento, o que mudou a partir do século XX. Até o século XVIII a tortura era uma prática legítima e os médicos se viam como representantes das autoridades. Se as Cortes tivessem dificuldade de condenar um acusado, a criminalidade aumentaria. Nesse sentido e para evitar tal dano, a tortura garantia a condenação de todos. Era um pré-requisito de "segurança interna". ${ }^{182}$

Do século XVI em diante, alguns médicos criticavam o envolvimento com tortura, dentre os quais, Johann W. Meyer (1515-1588), Fabricius Hildanus (1560-1634) e Ferdinand Leber (1727-1808). No entanto, eles não criticavam a crueldade da prática, uma vez que as drogas que aliviavam a dor já eram poucas considerado o número de pacientes, então, era comum as pessoas sentirem dor quando precisavam se submeter a algum procedimento médico, não havia compaixão, apenas a preocupação em manter o indivíduo vivo. Os médicos não condenavam o fato de infligir dor, não havia um argumento ético do mesmo modo que não se considerava a tortura um problema moral, o questionamento desses médicos se davam em relação à fidedignidade das confissões. A tortura se mostrava

\footnotetext{
${ }^{179}$ MAIO, G., op.cit., p. 1610.

${ }^{180}$ MAIO, G., op.cit., p. 1610.

${ }^{181}$ MILES, S.H., Oath Betrayed: America`s Torture Doctors, $2^{\mathrm{a}}$ ed., Berkeley and Los Angeles, California, University of California Press, 2009, p. 26.

${ }^{182}$ MAIO, G., op.cit., p. 1610.
} 
inútil ao ponto de ser abolida na Áustria, em 1776, por exemplo. Fica claro que os médicos não estavam apenas envolvidos com tortura, mas a legitimavam. ${ }^{183}$

Por sua vez, no século XX, o papel dos médicos na tortura mudou. Agora há uma participação ativa, inclusive, na invenção de novos procedimentos. O conhecimento científico da fisiologia da dor provocou uma alteração no modo como a tortura é realizada. Tradicionalmente apenas se fazia uso da dor física, ao passo que a tortura moderna envolve técnicas psiquiátricas, farmacológicas e psicológicas. A lavagem cerebral foi aperfeiçoada por meio da privação de sono, da simulação de uma execução, do isolamento, além da inserção de pessoas em locais escuros, de ameaças pessoais e de ser obrigado a assistir à sessão de tortura de outrem. Todas essas técnicas são utilizadas porque não deixam evidências visíveis na vítima, fato que se torna possível devido o aconselhamento de médicos. $^{184}$

A abolição da tortura necessariamente não fez cessar sua prática. No século XIX tornou-se algo realizado modo obscuro e no século XX explodiu como um crime contra a humanidade, sendo sua prática negada e realizada em locais secretos. ${ }^{185}$

A medicalização da tortura contemporânea, marcada pela participação de médicos e de outros profissionais da saúde, seja por livre e espontânea vontade, seja por coerção, constitui uma prática que começou a chamar a atenção desde o começo dos anos 1970, momento em que a imprensa divulgou que políticos opositores da União Soviética eram mantidos encarcerados em hospitais tendo como justificativa apenas sua opinião política, sem qualquer indicação médica. Durante o cárcere eram submetidos à força a administração de drogas. Além disso, os corpos eram constritos por um tecido molhado e encolhido. Todos esses procedimentos eram supervisionados por psiquiatras forenses da União Soviética. O Dr. Andrei Snezhnevsky, diretor do Instituto de Psiquiatria Soviético, defendia o diagnóstico de doenças inventadas em dissidentes, por exemplo, um "tipo específico de esquizofrenia”, assim poderia abusar desses pacientes com drogas e cirurgias cerebrais. $^{186}$

Em países da América Latina (Argentina, Brasil, Chile e Uruguai) atitudes como essas ocorreram durante as Ditaduras Militares, que duraram de meados dos anos 1960 até o fim dos anos 1980. O uso da tortura era brutal, e também contava com o auxílio de

\footnotetext{
${ }^{183}$ MAIO, G., op.cit., pp. 1610-1611.

${ }^{184}$ MAIO, G., op.cit., p. 1611.

${ }^{185}$ MILES, S.H., op.cit., p. 28.

${ }^{186}$ MILES, S.H., op.cit., p. 29.
} 
médicos, justamente por denotar um aspecto mais "científico" à obtenção de informações. Era usual ressuscitar os indivíduos em risco de morte que haviam sido submetidos às sessões de tortura, bem como o uso de conhecimentos médicos para dissimular os sinais de abusos, por meio de falsos atestados médicos e de óbito.

No Chile, um ex-prisioneiro relata que periodicamente um médico aconselhava pausar a tortura, também lhe injetava drogas quando sua pressão sanguínea ficava muito alta. Esse processo piora o sofrimento da vítima, pois além da dor demonstra que nem o aspecto humanitário da Medicina está ao seu lado em um momento de necessidade. ${ }^{187} \mathrm{Um}$ médico que serviu no regime de Pinochet, questionado a respeito da contradição moral entre tortura e Medicina, simplesmente respondeu: "O que você esperava? Estamos em guerra". ${ }^{188}$ Dessa forma, fica claro que os médicos, em determinadas circunstâncias, conseguem criar um vácuo moral.

Na Argentina, o Dr. Jorge Berges, condenado em 1986 a quatro anos de prisão pelo envolvimento com tortura, foi libertado no ano seguinte pela lei de obediência devida, a qual determinava que nenhum oficial ou funcionário das Forças Armadas poderia ser condenado pelos crimes cometidos durante os anos de Ditadura, pois sua atitude se justificaria em virtude da obediência devida.

Embora não haja dúvidas de que médicos brasileiros tenham auxiliado na tortura durante a Ditadura Militar, são poucas as informações obtidas, e muitas delas ainda permanecem inacessíveis. Autores como Steven H. Miles sempre comentam do caso do médico brasileiro Harry Shibata, no entanto, em sites brasileiros, por exemplo, o do Conselho Federal de Medicina ou o do Conselho Regional de São Paulo (Cremesp), não se obtém nenhuma informação detalhada sobre ele. Inexiste divulgação no Brasil sobre sua suposta investigação durante o período ditatorial. Vale ressaltar que no site da Anistia Internacional há a descrição de que o Dr. Harry Shibata teve sua licença médica cassada pelo Cremesp, em 1980, por seu envolvimento com tortura. Entretanto, em 1982, o Conselho Federal de Medicina discordou do julgado regional e o Dr. Shibata teve a cassação anulada. Em 1995, reaberto o caso, espera-se até hoje o conhecimento da sentença final. Embora não haja uma confirmação nacional em relação ao resultado do

\footnotetext{
${ }^{187}$ MILES, S.H., op.cit., p. 28.

${ }^{188}$ MILES, S.H., op.cit., p. 30.
} 
julgamento, esse caso é ilustrativo para os estrangeiros, porque demonstra a existência legal de sanções aos médicos que se envolvem com a tortura. ${ }^{189}$

Em recente lançamento (dezembro de 2011), a obra Desafia o nosso peito resistência, tortura e morte durante o regime militar brasileiro: as quedas na guerrilha urbana e os desaparecidos na insurreição do Araguaia: subsídios para a Comissão da verdade, do médico psiquiatra e psicanalista Adail Ivan de Lemos, desenvolve um capítulo a respeito dos médicos brasileiros envolvidos na tortura durante a Ditadura Militar. Segundo o autor, seu livro é fruto de extensa pesquisa bibliográfica e, apesar de publicado, está apto a eventuais correções, em razão de arquivos não abertos em mãos dos militares. Inclusive, afirma que o mais importante é estabelecer debates para, por meio deles, se aproximar da verdade histórica. Uma das fontes muito citadas na referida obra é a do projeto "Brasil nunca mais", desenvolvido clandestinamente entre 1979 e 1985, durante o período final da Ditadura Militar no Brasil, por Dom Paulo Evaristo Arns e pelo pastor presbiteriano Jaime Wright junto de suas equipes. Foram sistematizadas informações de mais de um milhão de páginas contidas em 707 processos do Superior Tribunal Militar (STM) revelando a extensão da repressão política no Brasil, em um período que vai de 1961 a 1979. Veja a seguir o que Lemos compreendeu disso tudo.

A obra Desafia o nosso peito afirma que os médicos colaboracionistas ajudavam nos Centros Oficiais de Tortura e Morte (COTMs) e nos Centros Clandestinos de Tortura e Morte (CCTMs). Eram essenciais, não para assegurar a sobrevivência e as condições de saúde dos presos políticos, mas para auxiliar em interrogatórios, violando seus princípios hipocráticos. ${ }^{190}$

Segundo Lemos, os médicos que trabalhavam para as Forças Armadas facilitavam e promoviam a tortura ao proceder um exame inicial cujo intuito era adequar o quadro clínico do preso a melhor técnica de tortura, explorando eventuais deficiências. Por exemplo, lesões cardíacas, que ameaçam o prisioneiro da possibilidade de parada cardíaca durante o uso de eletrochoque, uma clara violação ao dever de sigilo médico expresso no Código de Ética Médica. Além disso, mantinham os presos conscientes durante longos

\footnotetext{
${ }^{189}$ Site Anistia Internacional. Disponível em: $<$ http://www.amnesty.org/en/library/asset/AMR19/025/1996/en/24fcecde-eaf7-11dd-aad1ed57e7e5470b/amr190251996en.html >. Acesso em: 13 jul. 2011.

${ }^{190}$ LEMOS, A. I., Desafia o nosso peito - resistência, tortura e morte durante o regime militar brasileiro: as quedas na guerrilha urbana e os desaparecidos na insurreição do Araguaia: subsídios para a Comissão da verdade, Rio de Janeiro, Consequência, 2011, p. 185.
} 
interrogatórios por meio da administração de glicose na veia ou por compressas de amoníaco para recuperar os sentidos. ${ }^{191}$

Até 1971, a tortura no Brasil era caracterizada por castigos físicos e violentos. Com o advento da tortura científica, trazida pelos ingleses e norte-americanos, a presença de médicos psiquiatras era indispensável para monitorar a sessão em que se praticava esses atos de violência e orientar os torturadores. Tratava-se da "Operação Condor", pela qual os norte-americanos, com intuito de evitar a influência e a expansão das ideias comunistas na América Latina, ofereciam ajuda aos governos autoritários, afastando, desse modo, o "perigo vermelho soviético" durante a Guerra Fria. A proposta da nova técnica era a de um interrogatório calcado puramente no campo psicológico, fazendo uso de salas refrigeradas com ar-condicionado, totalmente escuras, sem janelas e com um ruído sonoro de alta frequência, de medicamentos hipnóticos ou, ainda, de salas de interrogatório inteiramente pintadas de branco e iluminadas de modo muito intenso. ${ }^{192}$ A força física começou a ser substituída pelo medo como forma de coação. Para que informações mais precisas fossem obtidas, a tônica da sevícia era desestruturar psicologicamente o preso antes mesmo dos castigos físicos, que seriam sentidos de maneira ainda mais devastadora. ${ }^{193}$

Nessa mesma obra, afirma-se que os médicos colaboracionistas da Ditadura também tinham de preparar os presos para serem apresentados em auditorias militares, durante transferência para unidades militares menos habituadas à tortura e nas ocasiões em que um "arrependido" iria se apresentar na televisão. O Dr. Amílcar Lobo configura um caso ilustrativo. Ele aplicou eletrochoque em uma prisioneira com paralisia nos membros inferiores e que precisava ser transferida. Ao constatar que a paralisia era emocional, o médico decidiu não esperar o efeito dos medicamentos psicotrópicos, então fez uso do eletrochoque para atender o prazo do comandante para a transferência. Em poucos instantes a "paciente" voltou a andar. A decisão do médico não foi a mais benéfica à presa, apesar de ele acreditar que fez uso de uma boa terapia, que resultou um duplo efeito positivo: a mulher além de se sentir melhor fisicamente, foi abençoada por um estado mental mais alegre, que a fez esquecer qualquer trauma da tortura. ${ }^{194}$

De acordo com Lemos, existiam diferentes tipos de médicos colaboracionistas. O cargo que ocupavam na hierarquia militar ou a necessidade de cumprir a norma do

\footnotetext{
${ }^{191}$ LEMOS, A.I., op.cit., p. 186.

192 LEMOS, A.I., op.cit., p. 186.

${ }^{193}$ LEMOS, A.I., op.cit., p. 187.

${ }^{194}$ LEMOS, A.I., op.cit., p. 188.
} 
alistamento constituía a principal razão aos profissionais que se envolveram diretamente com a tortura. Quando em serviço, esses médicos estavam sujeitos ao Código Penal Militar de modo que seus atos, por mais horrendo que fossem, estavam amparados pelo art. $5^{\circ}$ da Lei $n^{\circ}$ 6.681/1979, o qual os excluía de sanções dos Conselhos Regionais de Medicina. Ao final da Ditadura, quase todos alegaram o fato de terem sido coagidos a atos que não pretendiam cometer um crime, uma vez que obedeciam ordens de seus superiores hierárquicos. ${ }^{195}$ Muito similar às alegações de todos os médicos nazistas.

Os grupos eram de médicos de esquerda traidores, isto é, delatores, funcionavam como agentes infiltrados, pois pareciam defender a causa contra a Ditadura. Obtinham as informações, surpreendiam os companheiros, prendendo-os em emboscadas, e auxiliavam no interrogatório. Havia também o médico torturador conselheiro, diretamente envolvido com a prática de tortura, responsável por monitorar o atendimento emergencial e ressuscitar presos para o prosseguimento do interrogatório. Um dos nomes mencionados é o do Dr. Amílcar Lobo, citado anteriormente, que usava o codinome "Dr. Carneiro" (teve seu CRM cassado anos mais tarde pelo Conselho Regional de Medicina do Rio de Janeiro - CREMERJ). Os médicos conselheiros eram coniventes com a tortura, administravam injeções letais em alguns presos políticos, e sempre alegavam que ofereciam tratamento aos presos. Poucos deles tiveram o CRM cassado. ${ }^{196}$

Conhecimentos médicos vários foram utilizados para "otimizar" a tortura. O leito cirúrgico, por exemplo, no qual a pessoa era esticada e amarrada com o intuito de provocar o rompimento dos músculos e tendões, além disso, era utilizado para pequenas "cirurgias", como raspagem dos ossos das costelas, extração de unhas e pelos pubianos. Intensificavam a sensação de dor aplicando compressas molhadas em éter em regiões sensíveis do corpo, como pênis, ânus e vagina. Também administravam o famígero "soro da verdade", Pentotal, um barbitúrico que leva em um primeiro momento à sedação, seguido de leve anestesia e passividade, depressão e docilidade. Todo esse conjunto de procedimentos fundamentados na ciência médica conduziria a supostas confissões. No entanto, além do conhecimento científico, empregavam métodos coercitivos verbais, por exemplo, ameaças de estupro e, inclusive, a encenação de um aborto intencional para chantagear as presas. Os sobreviventes eram submetidos a um processo de recuperação, em outras palavras, suas lesões não podiam ser evidentes, tinham de ser disfarçadas. ${ }^{197}$

\footnotetext{
${ }^{195}$ LEMOS, A.I., op.cit., p. 190.

${ }^{196}$ LEMOS, A.I., op.cit., p. 192.

${ }^{197}$ LEMOS, A.I., op.cit., p. 198.
} 
Outro grupo de médicos colaboracionistas eram os legistas, também chamados "médicos falsificadores", pois cumpriam a de produzir laudos fraudulentos e falsificar atestados de óbitos dissimulando a verdadeira causa mortis. Segundo descrição de Lemos, o DOI-CODI, Departamento de Ordem Interna (DOI), ligado à análise de informações obtidas na tortura, e o Centro de Operações de Defesa Interna (CODI), órgão que além de centralizar o combate à oposição política, realizava busca e captura, se encarregava de encenar um tiroteio em local público, a fim de justificar os óbitos, obviamente, as mortes eram sempre dos guerrilheiros. Com frequência, os legistas produziam relatórios que omitiam fatos e alteravam detalhes necrológicos para evitar a descoberta das evidências dos crimes de tortura. No livro em questão é destacada a figura do Dr. Harry Shibata, que conforme o autor continua livre e sem impedimentos para exercer a Medicina. ${ }^{198}$

O quarto grupo de médicos são os designados "médicos de apoio", ou seja, profissionais que procuravam atenuar as consequências psicológicas da tortura, impedir sua divulgação e, eventualmente, confirmar ou acrescentar as informações recebidas pelos serviços de repressão política. Esses médicos trabalhavam para as Forças Armadas, mas não atendiam nos centros de tortura, sua missão era apenas dar suporte às vítimas e suas famílias. Quase nenhum deles foi denunciado, pois seus atos não pareciam tão graves quanto os dos médicos que participavam diretamente da tortura. Entretanto, é muito sério o ato de um médico que oculta as condutas antiéticas de outro companheiro profissional. Esses médicos tornavam psicologicamente aceitáveis os métodos brutais de interrogatório, induzindo as vítimas a considerá-los parte da realidade. Desestimulavam os sentimentos de vingança e intervinham de forma "caridosa" com medicação. Atenuavam os efeitos de insônia, emagrecimento, estresse pós-traumático etc. ${ }^{199}$

Desse modo, percebe-se que durante alguns anos, marcados por gestos maquiavélicos, a tortura no Brasil foi potencializada e auxiliada por médicos. Realizaramse várias violações ao Código de Ética Médica, mas poucos médicos foram efetivamente punidos. É importante que a sociedade brasileira não absorva essa equivocada "consciência da impunidade", especialmente em relação aos médicos colaboracionistas. A ausência de denúncias, de investigações e das respectivas punições, abrirá caminho para que a geração vindoura de médicos participe de ciclos de tortura. ${ }^{200}$ É exatamente isso que precisa ser evitado e rapidamente apurado, o caso norte-americano contra a suposta guerra ao terror,

\footnotetext{
${ }^{198}$ LEMOS, A.I., op.cit., p. 199.

${ }^{199}$ LEMOS, A.I., op.cit., p. 201.

${ }^{200}$ LEMOS, A.I., op.cit., p. 220.
} 
por exemplo, demonstra que essas atitudes, todavia, permanecem, conforme será estudado no item "c" deste capítulo.

Segundo discussão no Capítulo III, o surgimento de uma noção de "Direitos Humanos" ainda é um avanço recente. Esse advento influenciou a Medicina, que reagiu com a criação de padrões éticos. Em outras palavras, a violação dos Direitos Humanos cometida por um médico pode certamente ser considerada uma contravenção à ética médica. A visão universal do papel de um médico é a de cura, mas, além disso, esse profissional deve respeitar a dignidade de todos os indivíduos que estiverem sob seu cuidado, fazendo o possível para investigar abusos dos Direitos Humanos trazidos para sua atenção. $^{201}$

A ética médica determina princípios importantes que devem ser respeitados em toda e qualquer situação. $\mathrm{O}$ respeito pela autonomia se torna indispensável em um cenário de tortura, sendo assim, uma pessoa suspeita, condenada, terrorista, ainda é uma pessoa e tem o direito de decidir sobre seu próprio corpo. Há países no mundo, por exemplo, o Sri Lanka, onde os presos do grupo Tâmil são obrigados a doar sangue a fim de "reporem o sangue derramado de suas vítimas”. A Associação Médica Mundial já determinou que nenhum preso deve ser usado como doador de órgãos, pois, nessa circunstância, o consentimento estaria comprometido por coerções ou falsas promessas de um livramento condicional imediato. A única exceção nesse contexto se dá nos casos em que a doação destina-se a um parente próximo. ${ }^{202}$ Por sua vez, a confidencialidade não seria um direito absoluto, mas que sempre deveria ser respeitado no contexto prisional. Caso seja indispensável divulgar determinada informação, é devida uma explicação ao paciente. Todo exame deve ser realizado com privacidade, sem a presença de guardas, a exceção se dá quando um acompanhante é indicado devido à diferença de gênero entre médico e paciente. $^{203}$

O dever de cuidado do médico carece ser cumprido independente do objetivo do exame ou tratamento a ser realizado no preso. A partir do momento em que um médico é contratado por militares, polícia ou instituição prisional, ele enfrenta o problema da dupla responsabilidade, por meio da qual, além do dever de cuidado com os pacientes, é esperado que esse profissional desenvolva o papel de disciplinador, envolvendo-se em atos de

${ }^{201}$ SOMERVILLE, A.; REYES, H.; PEEL, M., "Doctors and Torture”, In: The medical Documentation of Torture, Edited by Michael Peel and Vicent Iacopino, New York, Cambridge University Press, 2009, p. 64. ${ }^{202}$ SOMERVILLE, A.; REYES, H.; PEEL, M., op.cit., p. 65.

${ }^{203}$ SOMERVILLE, A.; REYES, H.; PEEL, M., op.cit., p. 66. 
manutenção da ordem e monitorando atos de punição. Vale ressaltar, no entanto, que as punições deletérias jamais devem ser permitidas, porém o médico se encontra em posição de poucos poderes para proteger seus pacientes e, muitas vezes, se torna conivente com abusos de um código disciplinar severo. Diante disso, os presos não confiarão no médico que age como cúmplice do sistema e, nessas conjunturas, seus problemas se voltam bastante complicados. ${ }^{204}$

Além disso, um médico ao tomar consciência de abusos cometidos com os presos tem o dever de denunciar, isso dificilmente se concretiza, pois ele é submetido a muita pressão para tolerar esse tipo de comportamento. Muitas vezes, a divulgação desses abusos pode deixar a vítima ou sua família em grande risco, inclusive, o médico tem de considerar sua própria segurança, exigindo apoio de advogados, associações médicas nacionais ou da comunidade internacional. ${ }^{205}$

A experiência de um médico da antiga União Soviética, por exemplo, evidencia como os médicos podem agir em determinadas situações. Esse profissional presenciava diariamente os abusos, ou melhor, as brutais sessões de tortura cometidas com os presos recém-chegados. No entanto, ele obedecia ao comando militar do presídio e temia denunciar essas práticas de violência pelo risco a sua segurança e de sua família. Como solução, ele passou a documentar, às escondidas, em um caderno pessoal, tudo o que acontecia. Sua esperança era a de que um dia se daria uma investigação externa, com garantias de proteção às testemunhas, nesse dia ele poderia expor seus conhecimentos e, por meio de sua documentação, produzir evidências. Até então, sentia não haver nada que ele pudesse fazer, exceto continuar segundo o sistema. ${ }^{206}$

Os Princípios da Ética Médica das Nações Unidas, em seu segundo princípio, determina que:

É uma grave violação da ética médica, bem como uma ofensa ao abrigo dos instrumentos internacionais aplicáveis, por pessoal de saúde, especialmente médicos, para participar, ativa ou passivamente, em atos que constituem participação, cumplicidade, incitamento ou tentativa para cometer tortura ou outros tratamentos cruéis, desumanos ou degradantes. ${ }^{207}$

\footnotetext{
${ }^{204}$ SOMERVILLE, A.; REYES, H.; PEEL, M., op.cit., p. 66.

${ }^{205}$ SOMERVILLE, A.; REYES, H.; PEEL, M., op.cit., p. 67.

${ }^{206}$ SOMERVILLE, A.; REYES, H.; PEEL, M., op.cit., p. 67.

${ }^{207}$ Site da ONU. Disponível em: < http://www.cirp.org/library/ethics/UN-medical-ethics/>. Acesso em: 07 jul. 2011.
} 
Conforme já mencionado, a Associação Médica Mundial também apresenta uma definição de tortura. Apesar de ser claro que um médico não deve colaborar ou facilitar qualquer tipo de abuso, a palavra "participação", nesse contexto, não significa apenas prestar assistência aos torturadores ou testemunhar o ato em si. Há muitas situações nas quais os deveres profissionais do médico se deparam com a tortura: o exame de entrada dos presos na detenção, assim como o tratamento médico oferecido nesse mesmo local, aconselhar sobre o modo pelo qual um preso deve ser punido e sobre os métodos de tortura, auxiliar na tortura ativamente, usar os presos como sujeitos de pesquisa, visitas de médicos externos a um centro de detenção, documentação oficial dos presos em casos de alegação de tortura, tratamento daqueles que foram soltos, investigação de alegação de tortura de quem não está mais preso e documentação de alegação de tortura para buscar asilo. $^{208}$

De acordo com Miles, em síntese, médicos e psicólogos podem auxiliar os torturadores de seis maneiras, a saber: examinando o preso, monitorando o interrogatório, escondendo evidências de abuso, realizando uma pesquisa abusiva com o prisioneiro, desrespeitando, nesse caso, a autonomia inerente ao sujeito em relação a seu próprio corpo, não cuidar do preso como paciente e se silenciar sobre os abusos. ${ }^{209}$

Portanto, o "envolvimento" se relaciona com inúmeras atividades médicas, algumas plenamente éticas, outras calcadas no condão de levar os médicos a violações graves dos Direitos Humanos. Por exemplo, examinar o preso recém-liberado é uma atividade ética, no entanto, silenciar-se sobre os hematomas existentes para manutenção do uso da tortura na instituição é antiético. ${ }^{210}$ A seguir, observa-se cada uma dessas etapas supracitadas.

O exame de entrada do preso se justifica para determinar se ele possui alguma doença pré-existente, como asma, diabetes, e, se for o caso, a continuação de um tratamento. Se o medicamento existe naquela comunidade ou o próprio preso tem seu estoque é antiético negar o tratamento. $\mathrm{O}$ intuito desse exame nunca deve ser o de detectar fraquezas físicas e psicológicas do preso para explorá-las em um interrogatório. Nessa fase, a existência de ferimentos no preso, em geral, é atribuída pelas autoridades policias como uso de força razoável para realização da captura ou devido à resistência à prisão. Assim, dificilmente o médico irá descrever na documentação "ferimento não justificado" ou "uso de força não razoável". Nessas situações é menos usual que os médicos sofram pressão

\footnotetext{
${ }^{208}$ SOMERVILLE, A.; REYES, H.; PEEL, M., op.cit., pp. 67-68.

${ }^{209}$ MILES, S.H., op.cit., p. 31.

${ }^{210}$ SOMERVILLE, A.; REYES, H.; PEEL, M., op.cit., p. 68.
} 
para adulterar as informações do prontuário. O ideal é que esse prontuário de entrada no presídio seja bem completo, a fim de comparar e evidenciar em um momento posterior se o acusado foi vítima de tortura ou não. ${ }^{211}$

Muitos presos, vítimas de tortura, alegam que o tratamento oferecido pelos médicos foi sumário e sem compaixão. Além disso, nos casos em que um preso será interrogado, mas antes precisa de algum tipo de tratamento, seja medicação, seja, inclusive, uma hospitalização, isso deve constituir prioridade e ser bem administrado. Independente das pressões dos interrogadores, o médico não pode apenas "fazer um curativo", ele deve informar o fato de o "paciente" ainda não estar habilitado para responder questões por determinado período de tempo.

Outro problema enfrentado pelos médicos reside na decisão-protesto representada pela greve de fome. Um presidiário, nessa particularidade, resiste sem danos à sua saúde por duas ou três semanas. Se sua greve perdurar além, há muitos riscos envolvidos. Cabe ao médico informar à pessoa sobre os perigos do jejum prolongado e tomar nota do que ela deseja que seja feito quando não estiver mais capacitada racionalmente. $\mathrm{O}$ complicador vem à tona em respeito à autonomia do preso e à preservação da vida, pois nesse aspecto deve o médico respeitar a Declaração de Malta, tratada de modo mais profundo em momento adequado. ${ }^{212}$

As Regras Mínimas para o tratamento de prisioneiros, organizadas pela ONU, em 1957, afirmam que:

32. c. O médico visitará diariamente os presos sujeitos a tais punições e aconselhará o diretor caso considere necessário terminar ou alterar a punição por razões de saúde física ou mental. ${ }^{213}$

No entanto, o "Corpo de Princípios para a proteção de todas as pessoas sob qualquer forma de detenção ou aprisionamento", do Alto Comissariado dos Direitos Humanos das Nações Unidas, de 1988, não mais admite isso. Ao atestar que um paciente está apto para ser punido, metaforicamente, o médico decreta que ele pode ser mutilado, passar fome ou ser morto. Em uma profissão, estigmatizada pela cura e pelo alívio da dor e do sofrimento, isso é eticamente inaceitável. A punição no sistema penitenciário não deve e não constitui papel dos profissionais de Medicina. Apesar de não a ordenarem, eles

${ }^{211}$ SOMERVILLE, A.; REYES, H.; PEEL, M., op.cit., p. 68.

${ }^{212}$ SOMERVILLE, A.; REYES, H.; PEEL, M., op.cit., p. 69.

${ }^{213}$ Site do Alto Comissariado dos Direitos Humanos das Nações Unidas. Disponível em:

$<$ http://www.unhcr.org/refworld/docid/3ae6b36e8.html>. Acesso em: 12 jul. 2011. 
podem, sim, intervir avisando as autoridades sobre um método ser prejudicial à saúde do preso. A escolha da "solitária", isto é, do isolamento total do preso, é reconhecida pelo Comitê Europeu de Prevenção da Tortura como prática degradante e desumana. ${ }^{214}$

No tocante ao aconselhamento médico sobre métodos de tortura não é preciso enfatizar o fato de ser completamente antiético. O mesmo se diz sobre a atuação direta do médico na tortura, tais profissionais devem ser julgados em uma Corte local ou, caso não seja possível, em uma Corte internacional. ${ }^{215}$

Os procedimentos científicos que envolvem presos como sujeitos de pesquisa devem respeitar as normas de pesquisa humana, em especial a autonomia $\mathrm{e} o$ consentimento livre e esclarecido. Ao considerar, a realidade de um presídio, no entanto, isso pode ser facilmente distorcido e o médico responsável, tal qual durante a Segunda Guerra Mundial, na Alemanha nazista e no Japão, estará repetindo as atrocidades já sabida por todos. $^{216}$

O médico externo que visita um centro de detenção está investido de um papel especial, já que desligado da entidade e justamente por isso, pode avaliar a ocorrência de abusos no referido local. Isso integra a iniciativa de entidades, como a Cruz Vermelha e o Comitê Europeu de Prevenção de Tortura, já que ambos se valem de severas regras de confidencialidade para ter acesso aos presos. Em razão disso, há poucas publicações sobre as metodologias empregadas. Mas é importante ressaltar que para que um médico possa realizar esse tipo de investigação, ele deve apresentar um treinamento específico. ${ }^{217}$

O conteúdo descrito nos prontuários quando há alegação de tortura também é de extrema relevância. Conforme as pesquisas de Sommervile, Reyes e Peel, muitas vítimas reclamaram que os médicos não queriam ouvir sobre alegações de tortura e que apenas deviam cuidar dos ferimentos. A ética médica não aceita um prontuário evasivo e obscuro, por essa razão, o Protocolo de Istambul determinou as regras do que precisa ser anotado para evidências de tortura, se por algum motivo os médicos não as consideram, faz-se necessário uma nota e uma explicação. Em casos de prontuários discordantes, é legítimo aquele que seguiu as explicações do Protocolo. Essencial destacar que a ausência de sinais físicos não é determinante para concluir que não houve tortura. ${ }^{218}$ Entretanto, apesar de eticamente correto, sabe-se que diante de determinadas circunstâncias um médico é

\footnotetext{
${ }^{214}$ SOMERVILLE, A.; REYES, H.; PEEL, M., op.cit., p. 70.

215 SOMERVILLE, A.; REYES, H.; PEEL, M., op.cit., p. 71.

${ }^{216}$ SOMERVILLE, A.; REYES, H.; PEEL, M., op.cit., p. 71.

${ }^{217}$ SOMERVILLE, A.; REYES, H.; PEEL, M., op.cit., p. 72.

${ }^{218}$ SOMERVILLE, A.; REYES, H.; PEEL, M., op.cit., p. 72.
} 
pressionado a redigir o prontuário tendo em vista um conteúdo pensado a priori e de interesses pessoais de outrem, envolvendo-o em um dilema terrível entre sua própria segurança e a ética médica.

O Protocolo de Istambul de 1999, apoiado pela ONU, estabelece as primeiras diretrizes internacionais destinadas aos profissionais médicos e legais, cujo princípio é determinar se uma pessoa sofreu procedimentos de tortura. Esse documento detalha como deve ser uma evidência usada judicialmente em casos de tortura e se tornou um instrumento crucial no esforço global de encerrar a impunidade dos perpetradores. A Associação Médica Mundial trabalha junto com outras organizações para realizar esse trabalho. $^{219}$

O médico responsável por receber, no hospital, pacientes recém-saídos do presídio enfrenta algumas dificuldades. Por mais que pareça contraditório, ele pode se recusar a oferecer o tratamento, no entanto, em alguns casos essa atitude é a mais correta ao paciente, pois o médico recusa o tratamento justamente por ter a consciência de que há pessoas nas imediações do hospital que não aceitam a divulgação de um presidiário reclamando do tratamento recebido na penitenciária. Assim, o médico recusa tratamento, uma vez que isso representa um risco para o preso, que pode ser capturado novamente e sofrer novos abusos. Na África do Sul e no Chile não era incomum a polícia ou o Exército saquear hospitais em busca de arquivos desses pacientes. Em meio a toda essa vigilância, é absolutamente arriscado para o médico preservar essa confidencialidade. A Declaração de Tóquio, já mencionada anteriormente, auxilia os médicos sobre como proceder nessas situações. $^{220}$

Para a alegação de tortura de indivíduos em liberdade, o médico que auxilia a respectiva investigação, deve seguir as orientações das organizações que documentam as violações dos Direitos Humanos, o qual, obrigatoriamente, carece de um treinamento apropriado. Se a vítima busca asilo, o médico deve ser imparcial, pois mesmo se for comprovado que não houve tortura, o indivíduo ainda pode obter o asilo. $\mathrm{O}$ relatório médico deve ser claro, em linguagem neutra e preciso. ${ }^{221}$

Os argumentos expostos neste tópico, ilustram de maneira ampla alguns dos revezes enfrentados pelos médicos que se veem diante da tortura. A seguir, a história da

\footnotetext{
${ }^{219}$ Site da Associação Médica Mundial. Disponível em: $<$ http://www.wma.net/en/20activities/20humanrights/40torture/>. Acesso em: 12 jul. 2011.

${ }^{220}$ SOMERVILLE, A.; REYES, H.; PEEL, M., op.cit. p. 73.

${ }^{221}$ SOMERVILLE, A.; REYES, H.; PEEL, M., op.cit. p. 73.
} 
cumplicidade médica com a tortura evidencia que se pode antecipar e prevenir os abusos médicos. Cabe às sociedades médicas, aos educadores de médicos militares e aos próprios militares de alto escalão ensinar e incorporar essas lições. ${ }^{222}$

\section{c) Especialização da tortura por meio da ajuda médica: a experiência americana}

Inúmeros artigos foram publicados no The Lancet, British Medical Journal,The New England Journal of Medicine, dentre outros, quando informações sigilosas a respeito do tratamento dos presos em Guantánamo, Iraque e Afeganistão mostraram que abusos eram cometidos e havia omissão/participação de médicos. O que houve com esses profissionais?

O Dr. Steven H. Miles, professor de Medicina da Universidade de Minnesota e membro do Centro de Bioética, decidiu pesquisar sobre o assunto, e hoje é, junto de outros autores já citados, uma das maiores autoridades em matéria de envolvimento médico em atos abusivos em nome da guerra contra o terror. Sua obra Oath Betrayed: America`s Torture Doctors foi escrita a partir de mais de dez mil páginas de documentos do governo obtidos da União Americana de Liberdades Civis (em inglês: American Civil Liberties Union - ACLU), por meio de uma ação que culminou no Ato de Liberdade de Informação.

Ainda na introdução, Miles esclarece que sua obra não se trata da ética médica no campo de batalha, mas no tratamento oferecido aos capturados. O autor discorda que os abusos cometidos aos prisioneiros de guerra sejam apenas "justiça bruta" contra os terroristas, pois essa conjuntura causou a impopularidade mundial norte-americana, bem como iniciou a retaliação contra os soldados americanos capturados. Desde que divulgadas as fotos de Abu Ghraib, vários soldados dos Estados Unidos foram decapitados no Iraque e a maioria não conseguiu escapar, ser resgatado ou trocado. Portanto, o tratamento indigno de presos de guerra leva à reciprocidade de tratamento. ${ }^{223}$

Para contextualizar as decisões políticas por trás desses atos, faz-se necessário apresentar a sequência de eventos que provocou inúmeras violações dos Direitos Humanos durante o governo Bush.

\footnotetext{
${ }^{222}$ MILES, S.H., op.cit., p. 40.

${ }^{223}$ MILES, S.H., op.cit., p. xi.
} 
O vice-presidente Richard Cheney, o chefe de seus funcionários, David Addington, e o Secretário de Defesa, Donald Rumsfeld, foram os responsáveis por permitir que tanto as ideias de tortura quanto as novas políticas de prisioneiro fossem aprovadas. Após discussões, a secretária de Estado, Condoleeza Rice, e o presidente George W. Bush aprovaram o projeto.

Em 2002, a advogada do Departamento de Defesa, Diane Beaver, elaborou um pedido de técnicas mais duras de interrogatório em Guantánamo, sob a alegação de que seriam legalmente permissíveis se acompanhadas por um médico. Seis meses mais tarde, Rumsfeld fez a proposta de dois testes clínicos, o primeiro consistia no fato de o Tenente Coronel Beaver "salvaguardar" os prisioneiros, liberando os aprovados no préinterrogatório e monitorando os que, em seguida, eram conduzidos ao verdadeiro interrogatório. O segundo se baseava no apelo aos cientistas do comportamento para ajudar a criar maneiras de "manipular as emoções e fraquezas dos detidos para ganhar sua cooperação". Como resultado surgiu o Behavioral Science Consultation Team (BSCTs Time Consultor de Ciência Comportamental, em tradução da autora), conhecido como "Biscuits" (biscoitos). 224

Desde sua origem, o BSCTs foi criado para ajudar nos duros interrogatórios escolhidos pela administração Bush. Esse time se reportava à inteligência militar e não aos assuntos de saúde. O Dr. David Tornberg, assistente do secretário de saúde, afirmou não existir relação médico-paciente para interrogados. Em 2005, o cirurgião geral do Exército, Kevin Kiley, rejeitou a recomendação de que psiquiatras e psicólogos não poderiam ser membros do time BSCTs. Em junho de 2006, o Departamento de Defesa reiterou a distinção entre o médico que aconselha interrogadores e o responsável pela saúde dos presos. Alguns meses depois, em outubro, o Departamento de Defesa emitiu outra declaração exigindo que os médicos do time não deveriam encarar os presos como pacientes, além disso, sua lealdade era soberana ao Departamento, devendo aconselhar os interrogadores sobre as fragilidades dos presos e instruir a maneira de aplicar estressores físicos e emocionais. ${ }^{225}$

Em tese, o time BSCTs segue as regras da Convenção de Genebra, mas não faz menção à Convenção Contra a Tortura, da ONU, da qual os EUA é signatário. Seria o momento de se perguntar o motivo da existência de tratados, convenções e leis se elas definitivamente não são cumpridas, sequer mencionadas.

\footnotetext{
${ }^{224}$ MILES, S.H., op.cit., pp. xiii-xiv.

${ }^{225}$ MILES, S.H., op.cit., p. Xv.
} 
Ironicamente, os profissionais do time BSCTs só podem interpretar um relatório médico em busca de fraquezas do preso, não é de sua instância examiná-lo e liberá-lo para um interrogatório, nem monitorá-lo durante o mesmo, tal procedimento é considerado responsabilidade médica. ${ }^{226}$

Ademais, há relatos dos próprios prisioneiros de Guantánamo de que eram injetadas drogas durante o interrogatório. É famígero, por exemplo, o uso de um "soro da verdade". Trata-se de violação ética um médico auxiliar na preparação ou administração dessas drogas, seja para interrogatório, seja para a captura de um preso. Outro questão diz respeito à utilização de presos em experimentos sobre os métodos de interrogatório. A Convenção de Genebra determina tal conduta como um crime de guerra. ${ }^{227}$

A Agência Central de Inteligência norte-americana (CIA) e as Forças Armadas já pesquisaram sobre os efeitos da hipnose, uso de drogas, estresse físico e emocional e isolamento em interrogatórios. Entre a Segunda Guerra Mundial e os anos 1970, tanto a CIA quanto as Forças Armadas, sem falar em faculdades de prestígio e associações de profissionais da saúde se aliaram nesse tipo de pesquisa. Descobriu-se que coerção, ameaças e estresse eram ineficientes e contraproducentes, entretanto, isso não diminuiu o interesse em prosseguir com os estudos. ${ }^{228}$

Algumas das descobertas dessa pesquisa foram usadas por cientistas do comportamento que trabalhavam no programa Survival, Evasion, Resistance, Escape (SERE), cuja tradução em português seria Sobreviver, Evadir, Resistir, Escapar. Destinado para as Forças Armadas e agências de inteligência, esse programa preparava soldados e agentes da inteligência sobre como agir na eventualidade de serem capturados, para tal simulava-se a realidade de um cativeiro violento, incluindo sermões, dificuldades físicas que envolviam posições desconfortáveis, barulho, fome, uso de temperaturas extremas, desrespeito à Bíblia, humilhação sexual e até afogamento simulado (waterboarding). Durante a guerra contra o terror, os psicólogos militares usaram as técnicas aprendidas no SERE e as adaptaram para os interrogatórios. ${ }^{229}$ Ao ponderar esses aspectos é possível depreender que o ocorrido em Guantánamo e em outras prisões americanas configura além de tudo uma pesquisa sobre o comportamento em interrogatório e como aprimorá-lo. ${ }^{230}$

\footnotetext{
${ }^{226}$ MILES, S.H., op.cit., p. xvi.

${ }^{227}$ MILES, S.H., op.cit., pp. xvi-xvii.

${ }^{228}$ MILES, S.H., op.cit., p. xvii.

${ }^{229}$ MILES, S.H., op.cit., p. xvii.

${ }^{230}$ MILES, S.H., op.cit., p. xviii.
} 
Apesar dos comentários mordazes das Nações Unidas e das inúmeras notícias divulgadas sobre os abusos cometidos nessas instituições do Exército dos EUA, há uma inércia por parte da comunidade médica americana. As sociedades médicas não reagiram, não procuraram investigar, nem endurecer seus respectivos códigos, não há esforços para responsabilizar os profissionais envolvidos nessas atrocidades. ${ }^{231}$ Segundo as ideias de Miles, eles deveriam ser julgados a fim de servir de exemplo às próximas gerações de médicos, restaurando a humanidade em tempos de guerra e prevenindo futuros abusos. ${ }^{232}$

\section{c.i) Casos}

Em novembro de 2003, um guarda iraquiano conseguiu entregar uma pistola a um prisioneiro de Abu Ghraib, Ameen Sa eed Al-Sheikh. Avisadas por um informante, as autoridades ordenaram uma busca nas celas. Ao descobrirem o esquema houve uma contenda com Al-Sheikh que, em seguida, foi enviado ao hospital com um ombro deslocado e um tiro nas pernas. Quando retornou do hospital, um policial militar atingiu sua perna ferida com um bastão e exigiu que renunciasse ao Islã, em seguida, suspenderam-no pela mesma perna. Enquanto tudo isso acontecia, dois funcionários médicos assistiam, inclusive, o Sargento-médico Layton Reuben, que em três ocasiões encontrou Al-Sheikh algemado com os braços para cima da cabeça, de modo a pressionar o ombro machucado e a perna. Em todos os encontros o Sargento pediu que as algemas fossem retiradas, pois, segundo ele essa era a extensão de sua responsabilidade. Sob juramento, Layton afirmou que examinou Al-Sheikh em sua cela junto de outros dois oficiais, o Capitão Williams e o médico com posto de Tenente-coronel Ackerson, nessa ocasião confirmou que o ombro deslocado era resultado da algema sobre a cabeça. Do mesmo modo que não se encontra o prontuário médico do prisioneiro, nenhum dos envolvidos parece ter desejado denunciar o abuso. Meses mais tarde, uma nova investigação recomendava que, nessa situação de abuso, o médico Layton deveria ser disciplinado por omissão. Nada foi mencionado sobre o Dr. Ackerson. ${ }^{233}$

O histórico desse prisioneiro não termina aqui, a Sargento-médica Theresa Adams, também se deparou com Al-Sheikh sangrando por um dreno que deveria estar conectado a uma bolsa para prevenir infecções. Imediatamente, ela o levou ao médico responsável, de

\footnotetext{
${ }^{231}$ MILES, S.H., op.cit., p. xix.

${ }^{232}$ MILES, S.H., op.cit., p. xxvii.

${ }^{233}$ MILES, S.H., op.cit., pp. 3-4.
} 
escalão de coronel, o qual reconheceu o erro do hospital em deixar o catéter aberto, mas se recusou a removê-lo ou transferir o preso ao hospital adjunto. Questionado pela Sargento sobre o conhecimento das regras da Convenção de Genebra, ele respondeu simplesmente que iria voltar a dormir. Mais tarde, em investigação, o mesmo médico não se recordava do incidente envolvendo Al-Sheikh, apenas do seu ombro deslocado. ${ }^{234}$

Em 4 de novembro de 2003, Monadel al-Jamadi foi preso próximo a Bagdá, suspeito de ataques contra as Forças Armadas americanas. Ele lutou contra os soldados, mas o acorrentaram e o colocaram em um carro do Exército, foi espancado ao longo de todo o caminho até a base. Além de não receber os cuidados médicos necessários, levou uma pancada de rifle na cabeça, teve um saco amarrado em sua cabeça e estava nu abaixo da cintura, com frio e dificuldade de respirar. Al-Jamadi não entrou na prisão de Abu Ghraib como prisioneiro, em vez disso, a CIA o considerou um preso "fantasma", sem registro do nome e sem o exame médico comum aos presos recém-chegados. Ele foi interrogado com o saco na cabeça, levantado pelos braços, espancado e, possivelmente, submetido a afogamento simulado. Após todas essas condutas, ele estava morto. Um médico iraquiano a serviço da CIA pronunciou a morte.

Agentes da CIA aconselharam manter o corpo no gelo. No dia seguinte, um médico inseriu uma agulha de terapia intravenosa no cadáver, simulando uma doença e um procedimento para não afetar os outros presos. O cirurgião geral das Forças Armadas não acreditou que isso fosse uma manobra para ocultar homicídio. O Instituto de Patologia das Forças Armadas realizou uma autópsia e concluiu que Al-Jamadi morreu de "ferimentos e contusões complicados por respiração comprometida”. Considerou-se responsável por esse crime de guerra, o oficial que comandou a apreensão de Al-Jamadi. Oito soldados receberam reprimendas administrativas pelo abuso do preso, no entanto, os oficiais de alto escalão da CIA e os soldados do Exército que participaram não foram sancionados, assim como o médico que inseriu a terapia intravenosa. ${ }^{235}$

É importante explicar que as condutas em Abu Ghraib tem inspiração na base de Guantánamo. Em meados de 2003, muitos soldados americanos haviam sido mortos no Iraque, então, as táticas de interrogatório precisavam serem especializadas. Guantánamo havia se transformado em um centro de interrogatório. O presidente Bush havia decretado que os princípios da Convenção de Genebra não se aplicavam aos presos do Afeganistão e

\footnotetext{
${ }^{234}$ MILES, S.H., op.cit., p. 4.

${ }^{235}$ MILES, S.H., op.cit., pp. 43-46.
} 
de Guantánamo, ao passo que a Convenção relativa a proteção de civis em tempos de guerra era o tratamento aos presos no Iraque. ${ }^{236}$

Independente dos preceitos estigmatizados nos tratados internacionais de Direitos Humanos, os profissionais convocados para essa guerra eram muito jovens e despreparados, não tiveram treinamento militar orientado pelo Direitos Humanos. Esse despreparo culminou em vários sequestros e prisões de civis pelas ruas do Iraque para consequente interrogatório. Bastava a pessoa estar ao celular para ser capturada. ${ }^{237} \mathrm{Com}$ penitenciárias superlotadas e o temor de que os capturados e interrogados assim que libertados atacariam as tropas americanas, muitos iraquianos foram mortos ou mantidos presos.

Para orientar o processo de interrogatório, havia um quadro de regras no qual se destacava que ao eleger o método de manipulação da dieta (restrição de alimentos) o mesmo deveria ser acompanhado por um médico. Além disso, presos feridos ou sob tratamento deveriam receber aprovação médica antes do interrogatório. No fim de 2004, um time médico da Força Aérea alegou ter examinado todos os detentos de Abu Ghraib antes e depois dos interrogatórios. Entretanto, em 2005, o cirurgião geral do Exército constatou que apenas de 15 a 50\% dos presos no Iraque, Afeganistão e Guantánamo foram examinados antes dos interrogatórios. E menos de 15\% foram examinados em busca de ferimentos após os interrogatórios. ${ }^{238}$

Os exames realizados não eram para o bem-estar dos presos, mas para detectar o que cada um suportaria durante o período de detenção, por exemplo, privação de sono, isolamento, fome, ameaças etc. Não constava no prontuário médico do preso as anotações desses exames antes e depois do interrogatório, manobra que impediu o conhecimento do que realmente acontecia na realização desses exames, do mesmo modo que ocultou qualquer evidência de ferimento pós-interrogatório. ${ }^{239}$

Em Guantánamo, o sigilo médico era desrespeitado desde 2002, a partir da implementação da nova política de interrogatório. Os prontuários médicos tinham de ser divididos com os membros do time BSCTs, e, além disso, os médicos eram obrigados a dar sua opinião sobre as resistências físicas e emocionais do preso. O time BSCTs usava táticas maquiavélicas para fragilizar o interrogado, os torturadores investigavam os medos

\footnotetext{
${ }^{236}$ MILES, S.H., op.cit., p. 48.

${ }^{237}$ MILES, S.H., op.cit., p. 49.

${ }^{238}$ MILES, S.H., op.cit., p. 51.

${ }^{239}$ MILES, S.H., op.cit., p. 53.
} 
dos prisioneiros, por exemplo, se um deles tinha fobia à escuridão ou alguma outra vulnerabilidade isso era explorado. Conforme a cooperação do interrogado, os métodos poderiam ficar mais agressivos. ${ }^{240}$ Médicos acompanhavam os interrogatórios mais intensos atrás de um espelho ou ficavam presentes na mesma sala. De tempo em tempo checavam os batimentos do interrogado. ${ }^{241}$

Os diários de interrogatório detalhando a presença médica permanecem confidenciais, exceto um de Guantánamo, divulgado pela revista Time. ${ }^{242}$ Em 2002, o psicólogo do BSCTs, John Leso, monitorou o interrogatório de Mohammed al-Qahtani. Foram 55 dias de uso de isolamento, privação de sono, humilhação, uso de máscara, raspagem do cabelo, acorrentamento, ameaças com cães etc. Regularmente um médico monitorava tudo, chegando a administrar solução salina no preso enquanto estava amarrado a uma cadeira. Ao pedir para ir ao banheiro urinar, informaram-no para o fazer nas próprias calças. Em uma ocasião Al-Qahtani precisou ser hospitalizado com baixa frequência cardíaca devido à hipotermia causada propositalmente pela permanência excessiva no ar-condicionado. Os médicos cuidaram da hipotermia e o devolveram aos interrogadores. Somente agentes do Federal Bureau of Investigation (FBI - Departamento Federal de Investigação) reclamaram desse tratamento desumano, mas os médicos permaneceram silentes. $^{243}$

Por sua vez, Dilawar configura um caso de prisioneiro torturado por soldados americanos no Afeganistão, em dezembro de 2002. Com o emprego de práticas semelhantes as de Guantánamo, também teve um saco sobre sua cabeça que dificultava sua respiração. Sem poder beber água, foi acorrentado e suspendido pelos braços por horas, e espancado de tal maneira que suas pernas teriam de ser amputadas. Prometeram levá-lo ao médico, mas, em vez disso, o acorrentaram no teto de sua cela. Após tanto sofrimento físico e moral, um médico o encontrou morto. A autópsia constatou homicídio devido a contusões e ferimentos graves nos membros inferiores que complicaram uma doença arterial coronariana. No entanto, segundo a versão do Pentágono, o detento faleceu de causas naturais e para a imprensa noticiou-se que a causa mortis de Dilawar fora uma artéria obstruída. O médico que realizou a autópsia não divulgou seu relatório e, em vez de um único atestado de óbito, foram produzidas duas ou três versôes diferentes. Esse é um

\footnotetext{
${ }^{240}$ MILES, S.H., op.cit., p. 55.

${ }^{241}$ MILES, S.H., op.cit., p. 59.

${ }^{242}$ Site da revista Time. Disponível em: <http://www.time.com/time/nation/article/0,8599,1207633,00.htmll. Acesso em: 14 jul. 2011.

${ }^{243}$ MILES, S.H., op.cit., p. 61.
} 
caso em que certamente o médico, influenciado por autoridades do alto escalão, pretendeu conscientemente ocultar o abuso dos soldados. ${ }^{244}$

O Instituto de Patologia das Forças Armadas é responsável pela determinação da causa mortis dos presos do Iraque, Afeganistão e Guantánamo. Quase sempre, os patologistas não recebiam informações indispensáveis para poder determiná-la. Um patologista, mais do que a própria autópsia, também analisa a ficha médica do paciente, os relatos dos eventos antes da morte e uma descrição de como o corpo foi encontrado. Muitas informações eram consideradas sigilosas de modo que os patologistas tinham de se virar. Por exemplo, se a pessoa morreu asfixiada, ela estava com um saco na cabeça? Um patologista mal preparado não sabe determinar a causa de morte por atos de tortura. ${ }^{245}$ Para isso é importante reiterar a existência do Manual de Investigação Médica e Documentação sobre Tortura ${ }^{246}$, específico para profissionais da saúde e que ensina sobre como observar as evidências, por meio de sinais no corpo da vítima, e como proceder, documentar etc.

Os atestados de óbito não obedeciam a Convenção de Genebra e demoravam para ser divulgados, sendo que a culpa desse atraso era sempre atribuída aos patologistas. $\mathrm{Na}$ maioria dos atestados lia-se "morte por causas naturais", uma espécie de eufemismo cujo verdadeiro significado pode ser traduzido pela sentença "morte por tortura". As assinaturas dos médicos eram inseridas em datas diferentes, outra evidência que distorcia a realidade dos fatos. O preso Mohammed Khan, por exemplo, morreu em uma prisão no Afeganistão, segundo depoimentos de sua família, o corpo apresentava sinais de tortura. O Coronel responsável, no entanto, atestou a morte por mordida de cobra. Essa espécie animal existe, sim, na região, mas raramente interagem com humanos, sendo uma causa mortis extremamente improvável. Para se ter ideia dos esforços dispensados para ocultar as práticas de tortura, no caso de Khan nem ao menos a autópsia foi conduzida. ${ }^{247}$

As supostas mortes naturais, em geral, indicam que o preso morreu devido a um ataque do coração, porém, é importante considerar que os investigadores nunca correlacionam o tratamento abusivo e o, consequente, ataque fatal do coração ao estresse provocado por toda essa situação de sofrimento físico e moral. Pesquisas científicas demonstram que ameaças, espancamento, medo e interrogatório podem causar um

\footnotetext{
${ }^{244}$ MILES, S.H., op.cit., pp. 68-71.

${ }^{245}$ MILES, S.H., op.cit., p. 74.

246 PEEL, M.; LUBELL, N.; BEYNON, J., Investigação Médica e Documentação sobre Tortura - Manual para Profissionais de Saúde, $1^{\mathrm{a}}$ ed., Centro de Direitos Humanos, Universidade de Essex, Grã-Bretanha, 2005. Disponível em:

$<$ http://www.dhnet.org.br/denunciar/tortura/index.htm>. Acesso em: 02 nov. 2009.

${ }^{247}$ MILES, S.H., op.cit., p. 79.
} 
"homicídio por ataque cardíaco". Pessoas com histórico de doença coronária, desidratação, exposição ao calor e com sinais de exaustão estão mais sujeitas a esse risco. ${ }^{248}$

A morte do Major General iraquiano Abed Hamed Mowhoush foi semelhante ao caso de Dilawar, ele havia se apresentado voluntariamente às autoridades militares americanas e morreu torturado 16 dias mais tarde, em 26 de novembro de 2003. O chefe dos médicos dos presos, o Sargento Bernad Perry, e a Dra. Ann Rossignol testemunharam que logo em sua chegada o General foi brevemente examinado por um médico, que não documentou esse exame. Outras testemunhas dizem que Mowhoush foi espancado repetidas vezes com punho, um cano, galhos e a parte de trás de um rifle, tudo sob a supervisão do Exército, das Forças Especiais e da CIA. Ele teve seis costelas quebradas e foi enrolado em um saco de dormir a curta distância de fiação elétrica. Poucos minutos depois, Mowhoush parecia morto. ${ }^{249}$

Tanto o Sargento Perry quanto a Dra. Rossignol foram enviados à sala para auxiliar no procedimento de ressuscitação, ambos viram os médicos Sargento Chaheen e Capitã Maria Marlow tentarem a reanimação cardiorrespiratória por quase uma hora. $\mathrm{O}$ responsável pelo interrogatório informou à Dra. Rossignol que Mowhoush havia perdido o controle de sua urina e entrou em colapso, e assim ela não pediu mais detalhes. No julgamento dos soldados não perguntaram a ela sobre os machucados de Mowhoush nos braços, pernas, cabeça, pescoço, pélvis, frente e trás do torso, ou sobre a coloração avermelhada do rosto, resultado de sufocamento, afinal todos esses sinais eram claros para os investigadores do local e para o patologista, Dr. Michael Smith, que examinou o corpo. Em declaração à imprensa, Mowhoush disse que não estava se sentindo bem e tão rápido perdeu a consciência, então, houve a tentada de uma reanimação caridorrespiratória, no entanto, ele evoluiu em óbito, tendo uma morte por "causas naturais". ${ }^{250}$

Uma semana após a morte de Mowhoush realizou-se uma autópsia por meio da qual foi possível constatar traumatismos por todo o corpo e a morte por asfixia devido a sufocamento e compressão do peito. O respectivo atestado de óbito foi ocultado até maio de 2004 e o resultado da autópsia divulgado somente em abril de 2005. A dissimulação mediante as "mortes naturais" parecia ser a regra para o Exército americano. ${ }^{251}$

\footnotetext{
${ }^{248}$ MILES, S.H., op.cit., p. 82.

${ }^{249}$ MILES, S.H., op.cit., p. 88.

${ }^{250}$ MILES, S.H., op.cit., p. 89.

${ }^{251}$ MILES, S.H., op.cit., p. 89.
} 
Miles expõe em sua obra uma tabela de presos mortos por atos de tortura: oito no Afeganistão, dentre eles, dois sequer se sabia o nome, e um deles teve a ficha adulterada pelo médico para ocultar os abusos cometidos. No Iraque, 11 presos morreram por tortura, em três casos houve adulteração da ficha médica. Em outro, sequer foi investigada a causa da morte. ${ }^{252}$

Em outra tabela demonstra-se todas as práticas de torturas praticadas nos centros de detenção americanos no Iraque, Guantánamo e Afeganistão. Constituia uma espécie de manual para os algozes, divididos nas categorias dor, privação e psicológico. A primeira marcada pelas seguintes condutas: espancamento por punho, porrete, chicote, chute, choque da pessoa contra a parede etc; choques elétricos (eletrodos externos, internos e "parilla", que consiste em amarrar a pessoa em uma cama de metal e administrar choques); alongar ou suspender o indivíduo (com intuito de romper ligamentos, músculos ou causar asfixia); asfixia (imersão em água, obstrução da passagem de ar, compressão do peito e suspensão); queimadura (química, térmica); estrangulamento por garrote (membros, pênis); estupro; procedimentos médicos dolorosos (administração de drogas, enemas etc); mutilação (mordida de cachorro, tatuagem, piercing, desfolamento, amputação). Na categoria privação é característica a : privação de comida, água, acesso ao banheiro, abrigo do calor ou frio, cuidado médico (negar um tratamento até que a pessoa coopere), sono e sentidos (manter o sujeito no escuro e com protetor de ouvido). E, por fim, no que se refere ao psicológico tem-se: forçar a vítima a se autoflagelar, urinar em si mesma, masturbar-se, renunciar sua respectiva religião, confessar ou se acusar falsamente, passar em si urina e fezes alheias; abuso verbal por ameaça ao preso e a sua família, insultos, denegrir a religião do prisioneiro por meio de insultos; simulação de execução (o indivíduo é influenciado a acreditar que será executado); degradação sexual (nudez, toques); forçar a vítima a assistir abuso ou tortura de um ente querido; monopolização perceptiva (barulho alto, imobilização, luzes fortes e vendas, confinamento em local pequeno); administração de drogas que desorientam, por exemplo, tranquilizantes e alucinógenos; sequestro de crianças. $^{253}$

Em artigo recente, de dupla autoria, Vincent Iacopino, médico, conselheiro da entidade "Médicos pelos Direitos Humanos" (Physicians for Human Rights) e professor universitário e Stephen N. Xenakis, médico militar aposentado, ambos corroboram que na Baía de Guantánamo houve de fato negligência e ocultação de abusos cometidos por 
médicos contra os presos. Foram avaliadas nove fichas médicas de presidiários de Guantánamo e por meio das diretrizes do Protocolo de Istambul foi possível apreciar e comprovar a existência de tortura. Todos os detentos encarcerados em 2002 com idade média de 33 anos ficaram na base por cerca de sete anos. De acordo com seus próprios relatos todos foram submetidos a diferentes tipos de "técnicas de interrogatório reforçada": privação de sono, uso de temperaturas extremas, ameaças, posições desconfortáveis, espancamento e nudez forçada. Além das técnicas "autorizadas", foram submetidos aos atos de tortura "não autorizados", a saber: espancamento severo associado à perda de consciência, fratura de ossos, ataque sexual, ameaça de estupro, simulação de execução, simulação de desaparecimento, quase asfixia com água (inseriam uma mangueira na boca do detento), inserção da cabeça na privada, servir-se da cabeça do sujeito como esfregão para limpar o chão etc. ${ }^{254}$

Mediante essas fichas médicas, denota-se que ao enfrentar um problema de saúde mais cotidiano, por exemplo, diarreia, alergias na pele etc., o tratamento dispensado estava de acordo com o exigido. Entretanto, era terminantemente proibido questionar a origem de qualquer tipo de ferimento físico. Em determinada ocasião um médico apenas certificou-se da saúde de um detento para que ele pudesse continuar a ser interrogado, mesmo após ter perdido a consciência diversas vezes. ${ }^{255}$

As fichas médicas demonstram que nenhum dos nove detentos possuía qualquer problema psicológico antes de ingressar em Guantánamo. Após um período de detenção já foi possível documentar os seguintes sintomas: pesadelos, ideias e tentativas de suicídio, depressão, alucinações visuais, ansiedade, claustrofobia, dificuldades de memória e concentração e estado dissociativo. Apesar de todos representarem sintomas de estresse pós-traumático, nenhum dos médicos quis inquirir ou documentar as respectivas causas. A depressão era tratada com remédios e vistoria periódica para coibir suicídios. Em certa ocasião um detento escutou de um médico: "Você precisa relaxar quando os guardas estão sendo mais agressivos". 256

\footnotetext{
${ }^{254}$ IACOPINO, V.; XENAKIS, S.N., "Neglect of Medical Evidence of Torture in Guantánamo Bay: A Case Series", PLos Medicine, v. 8, Issue 4, April 2011, p. 2. Disponível em: $<$ http://www.plosmedicine.org/article/info\%3Adoi\%2F10.1371\%2Fjournal.pmed.1001027>. Acesso em: 14 jul. 2011.

${ }_{255}^{25}$ IACOPINO, V.; XENAKIS, S.N., op.cit., p. 3.

${ }^{256}$ IACOPINO, V.; XENAKIS, S.N., op.cit., p. 3.
} 
Conforme os estudos dos médicos que investigaram o material confidencial de Guantánamo não há evidências de que os detentos simulavam mal-estar ou ferimentos. ${ }^{257}$ Ademais, foi constatado que eles continuam a vivenciar severos sintomas psicológicos que podem persistir por toda sua vida. ${ }^{258}$

Na ilusão de criar uma técnica de interrogatório mais eficaz, fazendo uso da tortura "legal", já que monitorada por um médico, os limites foram extrapolados e os abusos jamais documentados e/ou impedidos pelos médicos que auxiliavam as forças militares envolvidas. Nesse sentido, conclui-se que a extensão da cumplicidade dos médicos americanos em práticas de tortura nunca será conhecida até que se dê cabo uma investigação completa, detalhada, imparcial e com livre acesso à informações confidenciais. A permanência dessa escuridão, implica a integridade ética dos médicos e de outros profissionais dasaúde que, todavia, está comprometida. ${ }^{259}$

Portanto, o estudo desses relatos permite identificar que diante de uma pretensa tentativa de aprimorar a obtenção de informações, cometeram-se abusos completamente injustificados por parte dos militares, com especial conivência de muitos médicos.

\section{c.ii) Greve de fome e o cuidado com os presos}

Conforme as Regras Mínimas para o tratamento de prisioneiros da ONU, os médicos também têm a obrigação de cuidar do ambiente do preso, ou seja, fiscalizar se está adequado do ponto de vista sanitário, verificar as refeições diárias, a higiene da instituição etc. É muito comum em um ambiente penitenciário que essas condições não sejam alcançadas, fato que também constitui uma violação da Convenção de Genebra.

Tanto no Iraque quanto no Afeganistão os médicos não possuiam uma infraestrutura para cuidar dos detentos, sequer recebiam os medicamentos ou equipamentos. Para se ter uma ideia da precariedade do tratamento oferecido em Abu Ghraib, além de ser realizado dentro da cela, os diabéticos, por exemplo, recebiam insulina somente quando havia e, nesse caso, não era ajustada de acordo com a dosagem de açúcar do sangue do paciente. Chegava-se ao limite de, muitas vezes, reutilizar luvas e seringas, procedimento que representava alto risco de contaminação e transmissão de doenças, como a hepatite. As fichas médicas não eram mantidas adequadamente, do mesmo modo que não

${ }^{257}$ IACOPINO, V.; XENAKIS, S.N., op.cit., p. 3.

${ }^{258}$ IACOPINO, V.; XENAKIS, S.N., op.cit., p. 4.

${ }^{259}$ IACOPINO, V.; XENAKIS, S.N., op.cit., p. 4. 
existia um protocolo a ser seguido. ${ }^{260}$ Os cuidados e acompanhamentos nos casos de doenças crônicas eram impossibilitados pela simples ausência de uma ficha organizada e eficaz, ademais não havia meios para facilitar a transferência de um prisioneiro ao hospital. ${ }^{261}$ Os médicos procuravam realizar o que estava ao seu alcance, sempre reclamando da falta de remédios, no entanto, não denunciavam às autoridades a situação precária de saneamento.

A situação dos que sofriam alguma doença mental era ainda mais dramática, pois não recebiam um tratamento adequado com remédios e acompanhamento psiquiátrico, pelo contrário, quase sempre, eram maltratados, abandonados em suas celas, sujos de fezes e urina, em temperaturas elevadíssimas. Alguns que tentavam se suicidar terminavam como vítimas de tratamentos ainda mais cruéis. ${ }^{262}$

Poucos presídios no Iraque e Afeganistão seguiam a Convenção de Genebra, de modo que muitos outros princípios eram violados, por exemplo, não pesavam os presos uma vez ao mês e a comida, além de ser preparada sem nenhuma higiene, não obedecia as exigências nutricionais. ${ }^{263}$

A partir do acima exposto a greve de fome se apresenta como um instrumento de protesto contra os abusos cometidos nos centros de detenção e de suas condições precárias, além de configurar uma maneira de atrair a atenção da imprensa etc. Alguns casos demonstram um apelo tão intenso a ponto de a greve se tornar coletiva, há uma pressão para que todos os presidiários integrem o movimento. Alguns recusam totalmente comida e água, situação que pode provocar a morte de modo rápido. Outros tomam líquidos e uma quantidade irrisória de comida. Essa fome lenta e gradual pode causar problemas cerebrais e cardíacos mesmo quando a greve é encerrada. Os grevistas precisam de aconselhamento médico para conseguir resistir à falta de alimentos sem danos permanentes a sua saúde. ${ }^{264}$

Nessas situações é de se esperar o dilema que se instaura para o médico, que fica entre a preservação da vida do preso e o respeito a sua autonomia. Alguns oficiais acreditam que essas greves geram uma perturbação, pois ameaçam a saúde dos presos, nessas circunstâncias a questão deve ser resolvida à força, mediante inserção de tubos de alimento diretamente nos estômagos dos grevistas, enquanto amarrados. A ética médica nao autoriza um tratamento forçado em paciente que, além de não o desejar, se encontra

\footnotetext{
${ }^{260}$ MILES, S.H., op.cit., p. 100.

${ }^{261}$ MILES, S.H., op.cit., p. 101.

${ }^{262}$ MILES, S.H., op.cit., p. 105.

${ }^{263}$ MILES, S.H., op.cit., p. 107.

${ }^{264}$ MILES, S.H., op.cit., p. 108.
} 
em estado de sã consciência. Ademais, se a razão da greve é protestar contra a tortura, a alimentação obrigatória terá como consequência a manutenção dessa prática. ${ }^{265}$

Para Roberto Augusto de Carvalho Campos e Rosmari Aparecida Elias Camargo, em respeito à autonomia, é possível ponderar o seguinte: "Mais do que o individuo valorizar a própria autonomia, cabe sim à sociedade criar subsídios para que esta autonomia prevaleça, pois assim ocorre a promoção da própria dignidade da natureza humana." 266 Nesse sentido, a autonomia deve ser respeitada, mas não de forma absoluta, por essa razão a Associação Médica Mundial se pronunciou sobre como o médico deve atuar nessas circunstâncias. Na Declaração de Tóquio, de 1975:

Onde o preso recusar alimento e é considerado pelo médico capaz de formar um juízo imparcial e racional sobre as consequências de sua recusa voluntária de alimentação, ele ou ela não devem ser alimentados artificialmente. A decisão sobre a capacidade do preso de formar tal julgamento deve ser confirmada por pelo menos outro médico independente. As consequências dessa recusa de alimento devem ser explicadas pelo médico ao preso. ${ }^{267}$

Por sua vez, em 1991, a Associação Médica Mundial, por meio da Declaração de Malta, detalhou as responsabilidades do médico no caso do preso em greve de fome. $\mathrm{O}$ médico deve avaliar se sua decisão é baseada em um critério racional, isso considera o fato de ela ser voluntária e não coercitiva. Deve ser desenvolvida uma relação de confiança e confidencialidade entre o médico e o presidiário, para a partir daí averiguar se há pressão de outros companheiros de detenção. O médico deve informar que a fome prolongada pode causar danos cerebrais, os quais são possíveis evitar mediante o consumo de determinadas vitaminas, mas normalmente, os guardas não permitem esse aconselhamento. ${ }^{268}$

Ainda sobre a Declaração de Malta, o médico deve perguntar diariamente ao preso sobre suas escolhas, o conflito surge a partir do momento em que o grevista decide pela morte, ou seja, mesmo em estado de coma ele não deseja ser alimentado. Esse ápice complexo e conflitante para o médico, se decidido sem coerção e com raciocínio normal do paciente, deve ser respeitado, o profissional de saúde deve sempre considerar a autonomia do indivíduo sobre seu próprio corpo. No entanto, o médico também tem o direito em

\footnotetext{
${ }^{265}$ MILES, S.H., op.cit., p. 108.

${ }^{266}$ CAMARGO, R.A.E.; CAMPOS, R.A.C., “A bioética e seus reflexos no direito”. Âmbito Jurídico, v. 37, p. 1, 2007. Disponível em: $<$ http://www.ambitojuridico.com.br/site/index.php?n_link=revista_artigos_leitura\&artigo_id=1706>. Acesso em: 14 jul. 2011.

${ }^{267}$ Site da Associação Médica Mundial. Disponível em: $<$ http://www.wma.net/en/30publications/10policies/c18/>. Acesso em: 14 jul. 2011.

${ }^{268}$ MILES, S.H., op.cit., p. 109.
} 
permanecer ou não com o tratamento. Caso não pretenda respeitar a deliberação do presidiário deverá então transferir os cuidados a outro médico. O essencial nessa circunstância é atuar em prol do paciente, sempre ponderando a decisão que ele tomou durante a greve de fome.

Em Guantánamo, por ordens do Departamento de Defesa, seguia-se a política de "alimentação forçada", para levá-la a cabo afastaram os médicos que expressavam alguma objeção a essa prática e selecionaram os favoráveis a ela, os quais examinavam os presos grevistas e decidiam quando era necessário o tratamento de alimentação involuntária. $\mathrm{O}$ procedimento consistia em inserir tubos pelo nariz dos prisioneiros que desciam pelo esôfago e chegavam ao estômago, às vezes, convocavam um radiologista para verificar por raios-X se o tubo estava mesmo no estômago e não no pulmão, amarrava-se o indivíduo em uma cadeira, impossibilitando-o de movimentar braços, ombros, pernas e cintura, ${ }^{269}$ uma violência extrema ao preso e poderia ser considerada tortura.

É importante ressaltar que conforme a "Declaração sobre a Proteção de Todas as Pessoas Contra a Tortura e Outras Penas ou Tratamentos Cruéis, Desumanos ou Degradantes", da ONU, dor e sofrimento advindos de condições prisionais que não atendem aos padrões mínimos constituem tortura. ${ }^{270}$ Portanto, não é exagero imaginar tanto o ambiente quanto as técnicas de interrogatório e a alimentação forçada, conformavam uma tortura aos presos em instituições penitenciárias americanas. Investidos pela justificativa da guerra ao terror e pela imaturidade das tropas em razão da tenra idade, muitos abusos e maldades foram cometidos. Os médicos poderiam ter se pronunciado. Porque se mantiveram silentes?

\section{d) Exame físico - documentação da tortura}

Um dos métodos de se produzir evidência em casos de alegação de tortura é o exame físico realizado por um médico. As Cortes o aceitam como prova, no entanto, a ausência de vestígios físicos, não implica necessariamente na ausência de tortura, esse é o maior desafio para o profissional de saúde: investigar e determinar os sinais de ocorrência desse abuso.

\footnotetext{
${ }^{269}$ MILES, S.H., op.cit., p. 110.

${ }^{270}$ MILES, S.H., op.cit., p. 117.
} 
As formas para documentar a tortura variam de acordo com o histórico da vítima. Existem centros de reabilitação para vítimas de tortura em diferentes lugares do mundo, neles os funcionários são treinados para oferecer o conhecimento médico, psicológico e legal de modo a ajudar essas pessoas. Quando a vítima não está sob a custódia dos torturadores, é mais simples e seguro que ela se aproxime desses centros para buscar ajuda e proteção. A realidade dos detentos que sofrem esses abusos, no entanto, em especial os que continuam na instituição, é completamente diversa, pois as mesmas autoridades que fazem uso da tortura continuam no controle do "bem-estar" e "segurança" desses indivíduos. Cabe ao médico externo, que realiza visitas periódicas, oferecer conforto ao preso e tentar obter informações, mas não representar um risco a ele. ${ }^{271}$

O Comitê Internacional da Cruz Vermelha há anos realiza visitas a prisioneiros de países que vivem conflitos e já são experientes para saber quando uma visita pode significar mais problemas do que ajuda aos presos. A referida organização procura vistoriar as condições do local e averiguar a possível prática de abusos, vide tortura, para salvaguardar a dignidade humana dos detentos. ${ }^{272}$

Reyes ensina que, por questões psicológicas, ao entrevistar um preso não se deve obrigá-lo a delatar as práticas ilegais, pois tal fato permite que ele "reviva" a tortura e adquira um trauma. Forçar esse tipo de situação pode ser ainda mais estressante ao preso, já que ele permanece na instituição. ${ }^{273}$ Tendo em vista a realidade nos centros de detenções, uma simples visita nunca cumprirá o papel de uma sessão de terapia.

Durante a visita, o ideal seria o médico ficar a sós com o preso, sem a presença de guardas e em respeito à privacidade, inclusive, nos casos em que a pessoa tenha de se despir. Outro detalhe importante: o médico não pode realizar apenas uma visita, isso providenciaria informações sobre a tortura, mas colocaria em risco a vida dos presos, é necessário um conjunto planejado de visitas. Não obstante, para que uma pessoa revele uma informação tão grave é preciso estabelecer uma relação de confiança e confidencialidade, afinal ser torturado envolve muita humilhação, física e moral. ${ }^{274}$

O consentimento do preso deve ser sempre respeitado. Ao longo das visitas, a relação médico-paciente atinge um nível de confiança e, muitas vezes, o sujeito quer apenas desabafar sobre sua experiência. Em outras palavras, se o preso preferir que seu

\footnotetext{
${ }^{271}$ REYES, H., "Visits to Prisoners and Documentation of Torture", In: The Medical Documentation of Torture, Edited by Michael Peel and Vicent Iacopino, New York, Cambridge University Press, 2009, p. 78.

${ }^{272}$ REYES, H., op.cit., p. 80.

${ }^{273}$ REYES, H., op.cit., p. 80.

${ }^{274}$ REYES, H., op.cit., p. 84.
} 
nome não esteja associado à documentação, por questões de sua segurança e a de sua família, o médico deverá respeitar, mesmo que a informação represente uma evidência indispensável para denunciar um crime. É seu dever tratar o paciente com compaixão, oferecendo-lhe, ao menos, conforto. ${ }^{275}$

É comum o presidiário pedir ao médico que o escute simplesmente e não faça anotações. O motivo, às vezes, não é o desejo de preservar a própria identidade, mas uma associação psicológica, pela qual o formato "pergunta/resposta/anotação" o faz lembrar dos interrogatórios, provocando sentimentos ruins. Nesse sentido, o "não fazer o mal" do médico se daria pelo simples gesto de soltar a caneta e escutar. ${ }^{276}$ A empatia, o clima de confiança, o respeito às diferenças de gênero (homem examinar homem, por exemplo) podem significar uma entrevista e um exame de sucesso. Inclusive, durante as perguntas, é essencial o médico ter a sensibilidade de não ser direto, mas pensar em questões abertas, por exemplo, "Quando o senhor foi preso, como foi?". ${ }^{277}$

Feitas essas considerações, será estudado como proceder com o exame nos casos de alegação recente de tortura. $\mathrm{O}$ médico deve considerar o tempo que se passou desde o momento inicial da lesão até a cicatrização. Uma lesão aguda mostra um padrão de ferimento proposital, com formato específico, determinado grau de repetição e o modo como se distribui pelo corpo. Também carece apalpar a região ferida para verificar se há inchaço, comparar a coloração da pele e averiguar a existência de infecção. Além disso, faz-se necessário avaliar o sistema cardíaco, respiratório e o sistema nervoso central, e buscar sinais de queimadura por eletrochoque, problemas na medula espinhal, atentar se os joelhos estão em ordem (lesão no tendão, deslocamento, luxação, espasmos nos músculos). As anotações devem seguir o diagrama do Protocolo de Istambul. De acordo com a gravidade do caso, outros exames devem ser solicitados, já que muitas lesões são detectadas apenas em um segundo momento. Para organizar uma completa documentação, é importante fotografar as evidências aparentes e os procedimentos dispensados. ${ }^{278}$

Segue uma explanação das feridas que podem ser observadas no corpo humano, vítima de tortura.

\footnotetext{
${ }^{275}$ REYES, H., op.cit., p. 86.

${ }^{276}$ REYES, H., op.cit., p. 88.

${ }^{277}$ REYES, H., op.cit., p. 90.

${ }^{278}$ OZKALIPCI, O., "Physical Examination following allegations of recent torture", In: The medical documentation of torture, Edited by Michael Peel and Vicent Iacopino, New York, Cambridge University Press, 2009, p. 134.
} 
Escoriações (esfoladuras), significam o esfolamento das porções superficiais da epiderme ou a destruição das mesmas por aplicação tangencial de uma força contra a superfície abrasiva de um objeto contundente. Por exemplo, um indivíduo arrastado apresenta sinal claro de infecção do contato da pele com a areia, o asfalto etc. Também pode resultar do atrito com uma corda durante a tentativa de se libertar. ${ }^{279}$

As contusões ou machucados, gerados por um trauma brusco no tecido subcutâneo, cuja consequência é a ruptura dos capilares sanguíneos, que extravasa no tecido vizinho. Essa lesão pode ocorrer tanto na pele quanto nos músculos e órgãos internos, e o grau de perigo depende da força aplicada. Idosos e crianças possuem um sistema vascular que permite a formação de hematomas mais facilmente do que em jovens e adultos. Dependendo do formato do machucado é possível constatar o objeto que o provocou, por exemplo, um bastão, uma bengala etc. É importante requerer mais de um exame, pois há casos em que o hematoma se encontra nas camadas subcutâneas e demoram muitos dias para se tornar visível. ${ }^{280}$

As lacerações são resultado de rasgo ou quebra da pele por meio da pressão de uma força abrupta. Por outro lado, as incisões são feridas causadas por objeto cortante, como facas, baionetas, vidro quebrado etc. A aparência mais aguda as distingue das lacerações, que são sempre mais irregulares. ${ }^{281}$

As queimaduras, causadas por contatos da pele com materiais quentes ou substâncias químicas, constituem a forma de tortura que mais deixam cicatrizes. $O$ grau de prejuízo depende da intensidade do calor e da duração da exposição. Queimaduras de primeiro grau são avermelhadas e saem com o tempo, chegando a desaparecer antes do exame médico. As de segundo grau são úmidas, vermelhas, com bolha e completa destruição da epiderme, inclusive, destruição parcial das camadas mais profundas. Por fim, as de terceiro grau destroem todas as camadas da pele. ${ }^{282}$

Dependendo do formato da queimadura é possível identificar o objeto que a originou, as provocadas por cigarro, por exemplo, deixam uma marca vermelha circular ou oval de 5 a $10 \mathrm{~mm}$ de diâmetro, com edema subepidermal e uma bolha. $\mathrm{O}$ olhar atento e cuidadoso do médico consegue perceber a existência de pelos queimados ao redor da lesão, que, com o passar do tempo, pode ficar amarela esverdeada com pus ou úlceras na base da

\footnotetext{
${ }^{279}$ OZKALIPCI, O., op.cit., p. 135.

${ }^{280}$ OZKALIPCI, O., op.cit., p. 135.

${ }^{281}$ OZKALIPCI, O., op.cit., p. 136.

${ }^{282}$ OZKALIPCI, O., op.cit., p. 136.
} 
lesão. Em seguida, se forma uma crosta dura e marrom, com a mesma tonalidade amarela esverdeada no centro. ${ }^{283}$

Uma queimadura por aparelhos elétricos, comumente, apresenta uma cor entre o vermelho e o marrom, são circulares com 1 a 3 mm de diâmetro, é raro haver infecção, mas pode resultar em uma cicatriz hiperpigmentada. É realmente difícil identificá-la, pois produzem modificações histológicas, inclusive, em alguns casos é necessário realizar biópsia. $^{284}$

As mordidas podem ser de humanos ou de animais, as primeiras produzem uma marca ovoide ou elíptica em padrão e é mais simples do que as de animais. A petéquia, pequeno ponto vermelho causado pela hemorragia dos vasos sanguíneos, é de origem humana, provocada por uma sucção de natureza sexual, é visível de uma até 24 horas após o ato. Por sua vez, as mordidas de animais furam e rasgam os tecidos, enquanto a humana apenas comprime. Cães deixam marcas com arco estreito e sinais dos caninos de forma proeminente. Gatos deixam um arco pequeno, redondo e com furos de caninos, além dos arranhões de suas unhas. Roedores deixam marcas de mordida pequenas com destaque no incisivo central. ${ }^{285}$

As fraturas, quebra da integridade do osso por efeito de força abrupta ou queda, quando relacionadas à tortura são mais comuns nos ossos do nariz, costelas, rádio, ulna, mão, vértebra, cóccix. O osso do pescoço e a cartilagem da laringe podem sofrer fraturas parciais devido a estrangulamento. Caso exista o aparelho específico, recomenda-se que o médico faça uma radiografia. Lesões nos tendões, ligamentos e músculos são melhor avaliadas por meio de ressonância magnética, mas também é possível fazer uso da artrografia. No entanto, a ressonância é mais indicada para detecção de hemorragias. ${ }^{286}$

As reclamações de dores no corpo conformam evidências de espancamento, suspensão ou outras torturas que envolvam uma posição desconfortável. Deve o médico examinar o sistema musculoesquelético do paciente, além de verificar limitações nas juntas, inchaços, parestesia, formigamento, perda de sensação ao toque e dos reflexos do tendão. ${ }^{287}$

Para investigar a ocorrência de traumas, danos no sistema sensorial e periférico, e problemas vestibulares pré-existentes, é indispensável solicitar exames neurológicos.

\footnotetext{
${ }^{283}$ OZKALIPCI, O., op.cit., p. 136.

${ }^{284}$ OZKALIPCI, O., op.cit., p. 137.

${ }^{285}$ OZKALIPCI, O., op.cit., p. 138.

${ }^{286}$ OZKALIPCI, O., op.cit., p. 139.

${ }^{287}$ OZKALIPCI, O., op.cit., p. 139.
} 
Ferimentos na região da cabeça são mais complexos, senti-la com as mãos somente não permitirá um exame eficaz, pois será possível perceber apenas o inchaço, desse modo, fazse necessário realizar uma tomografia ou ressonância magnética, para investigar se há hemorragia e edemas. Vítimas sacudidas violentamente podem sofrer dores de cabeça recorrentes, desorientação e mudança do estado mental, esse tipo de tortura não deixa marcas visíveis, exceto algum sinal nos ombros ou peito, mas há relatos de pessoas que morreram devido a essa violência, portanto, cabe ao médico esgotar todas as possibilidades que estiverem ao seu alcance. ${ }^{288}$

Nos olhos, o médico deve buscar sinais de conjuntivite hemorrágica, deslocamento do cristalino, hemorragia subhialoide, hemorragia na retina e perda visual. Nos ouvidos, pode-se ter um hematoma externo causado por uma pancada, nessas violações é preciso verificar rompimento do tímpano, perda auditiva, vertigem, falta de firmeza e mesmo paralisia facial. Recomenda-se um audiograma, tomografia ou ressonância para verificar a ocorrência de fraturas. ${ }^{289}$

No nariz examina-se o alinhamento, se permanece ou não, o desvio do septo, a emissão de ruídos ao passar a mão e uma radiografia é capaz de detectar a existência de fratura. O desvio do septo provoca obstrução nasal, é importante se atentar a esse detalhe, e em casos mais graves, por exemplo, rinorreia, deve ser feita uma tomografia ou ressonância magnética. $\mathrm{O}$ maxilar e os dentes também precisam passar por exames, se choque foi aplicado na boca, tanto a língua quanto as gengivas e os lábios puderam ser mordidos. Uma síndrome na mandíbula, resultado de golpes no rosto ou eletrochoque, origina dor, limitação de movimentos e até luxação das juntas. ${ }^{290}$ Os dentes precisam ser avaliados tendo em vista o histórico dental do paciente. Pode haver fraturas na mandíbula, avulsões, fraturas nos dentes, próteses quebradas, gengiva inchada, sangramento, dor, perda de preenchimentos dos dentes, ferimentos oriundos de eletrochoque e pancadas. Cáries e gengivite devem sempre ser avaliadas e em prisioneiros com os dentes em estado muito precário, orienta-se o emprego de raios-x ou ressonância. ${ }^{291}$

O peito e o abdômen exigem muita atenção, devido aos possíveis hematomas intramusculares, retroperitoneais e intra-abdominais, assim como laceração e ruptura de órgãos internos. Aconselha-se exame de ultrassonografia, tomografia e cintilografia óssea,

\footnotetext{
${ }^{288}$ OZKALIPCI, O., op.cit., p. 140.

${ }^{289}$ OZKALIPCI, O., op.cit., p. 141.

${ }^{290}$ OZKALIPCI, O., op.cit., p. 141.

${ }^{291}$ OZKALIPCI, O., op.cit., p. 142.
} 
além dos cuidados com o sistema cardiovascular, pulmões e abdômen. Em conjunturas de quase asfixiamento não há marcas, fato que provoca problemas respiratórios agudos ou crônicos. Se uma costela foi fraturada, deve-se checar eventual laceração pulmonar e pneumotórax, caso a fratura tenha sido em região mais baixa, do lado direito, é importante verificar os ferimentos hepáticos. O comprometimento do abdômen implica a observação do sistema urinário e dos órgãos abdominais. Enquanto a presença de sangue na urina é sinal de rim contundido, o edema peripancreático evidencia uma pancreatite traumática e não traumática. $\mathrm{O}$ ultrassom investiga os hematomas no baço e as hemorragias são detectadas de modo mais eficaz por meio de tomografias. Falha renal pode ser resultado de surras intensas. $^{292}$

Após discrição de todo esse panorama sobre os danos provocados pela tortura, ainda é possível afirmar que não raro o profissional de saúde pode se deparar com falsas alegações de abusos contra a pessoa humana, a qual intui se beneficiar com um asilo político ou, simplesmente, apresenta algum problema mental, nesses casos, o médico não deve descartar uma opinião psiquiátrica. Uma autolesão normalmente é superficial e se dá em locais do corpo de fácil acesso. Estima-se que de duas mil pessoas vítimas de tortura, apenas três configuram falsas alegações. ${ }^{293}$ Portanto, mesmo sem sinais tão evidentes, deve o médico estudar o caso, a história relatada e confrontar essas informações a fim de atestar a veracidade das informações, sempre considerando as diretrizes do Protocolo de Istambul.

O médico responsável por examinar uma vítima de tortura, cuja alegação se refere ao ato ocorrido há muitos meses ou anos deve tomar algumas cautelas, por exemplo, observar como o paciente se porta, caminha, se senta, se está agitado ou calmo. Importante destacar, no entanto, que a mansidão não expressa obrigatoriamente a ausência de tortura na vida de um sujeito, como auxílio para esses nuances da personalidade, o médico pode convidar um psicólogo ou psiquiatra para acompanhar a sessão. Tudo o que for relatado deve ser levado em conta para atestar se as lesões são consistentes com a história. Muitas vezes, os algozes vedam os olhos da vítima, impedindo a real consciência dos atos praticados, inclusive, devido ao nervosismo, ela pode imaginar que uma cicatriz dos tempos de infância seja resultado da tortura. Outro aspecto ao qual o médico deve atentar são os indícios de depressão, que podem potencializar os efeitos pós-tortura. Ao examinar

\footnotetext{
${ }^{292}$ OZKALIPCI, O., op.cit., p. 142.
}

${ }^{293}$ OZKALIPCI, O., op.cit., p. 146. 
o corpo, o pudor da vítima deve ser respeitado, não é necessário remover toda a roupa de uma só vez, mas expor aos poucos, sem pressa alguma. ${ }^{294}$

Os médicos que auxiliaram nas técnicas reforçadas de interrogatório criaram métodos de tortura para garantir o máximo de dor e o mínimo de evidências físicas. Assim, o médico que examina uma vítima dessas técnicas especiais tem de apresentar um conhecimento especial sobre elas, a fim de conseguir enxergar além da pele e diagnosticar os sinais tão tênues. A vítima deve relatar o máximo de detalhes que se lembrar, inclusive, se foi vendada, se perdeu a consciência etc. ${ }^{295}$

As surras são sempre planejadas com antecedência para que os efeitos sejam disfarçados, nesse sentido, os torturadores optarão por objetos pesados, mas maleáveis, por exemplo, saco de areia, cano de PVC, ambos machucam o indivíduo, mas evitam a permanência das cicatrizes. Em outros casos, os torturados são espancados com um pano ou toalha enrolada, o impacto do golpe é forte, pode, inclusive, ferir os músculos, gerar sangramento interno, problemas renais, mas não haverá evidências externas aparentes, dificultando o trabalho dos médicos responsáveis por investigar os abusos.

A "Falaka", prática típica do Oriente Médio, caracterizada pelo espancamento repetido dos pés descalços com bengalas, chicotes, bastões, pode ser dissimulada se os torturadores obrigam a vítima a molhar o pé no sal, para reduzir o inchaço, e forçam-nas a vestirem os sapatos sobre os ferimentos. Se o médico examinar a vítima nos estágios iniciais perceberá o inchaço e ferimentos, além disso, o indivíduo não conseguirá ficar de pé, devido às possíveis fraturas no metatarso ou nos dedos, identificados por meio do simples toque. Se não for o caso, recomenda-se raios-x ou cintilografia. Na eventualidade de o médico examinar a vítima muito tempo após o abuso, deverá ficar atento à reclamação do paciente de não conseguir caminhar longas distâncias, das dores ao ficar de pé e das dores intensas durante à noite, especialmente, quando do contato dos pés com o lençol. As canelas e juntas também apresentariam problemas, assim como a pele da sola do pé evidenciaria cicatrizes, semelhantes as lesões de um atleta. Para aprimorar a investigação, deve-se fazer uso dos raios-x, cintilografia e ressonância magnética. ${ }^{296}$

\footnotetext{
${ }^{294}$ KIRSCHNER, R.; PEEL, M., "Physical Examination for late signs of torture", In: The medical documentation of torture, Edited by Michael Peel and Vicent Iacopino, New York, Cambridge University Press, 2009, p. 151.

${ }^{295}$ FORREST, D., "Examination following specific forms of torture", In: The medical documentation of torture, Edited by Michael Peel and Vicent Iacopino, New York, Cambridge University Press, 2009, p. 160. ${ }^{296}$ FORREST, D., op.cit., pp. 161-162.
} 
As pancadas no ouvido podem causar danos auditivos, mas o problema ocorre especialmente quando um golpe é desferido em ambos os ouvidos, com as mãos, toalha molhada etc., tal violência provoca sangramento imediato e surdez em razão do rompimento do tímpano. No entanto, esses ferimentos amenizam em um curto período de tempo, eliminando vestígios para o médico diferenciar a perfuração causada por infecção da produzida por um trauma. ${ }^{297}$

Em relação aos olhos, os danos causados às vítimas se dão obrigando-as a olhar para o sol ou luzes fortes por longos períodos, alternadamente, deixam-nas por meses em total escuridão. Os sobreviventes reclamam de lacrimação e fotofobia. Entretanto, esses casos não demonstram nenhuma anormalidade detectável e o tratamento é apenas sintomático. $^{298}$

Segundo a regra 33, das Regras Mínimas da ONU, o uso de grilhões é terminantemente proibido para prender um indivíduo, ainda assim, prisões do Paquistão a utilizam. Os anéis que prendem as canelas são fechados muito rentes a pele, causando escoriações e cicatrizes. Em países da África é possível constatar o emprego do "nó de cinco pontos", por meio do qual o capturado é amarrado com apenas uma corda ao redor dos pulsos, canelas, pescoço e boca, deixando o tronco no máximo de extensão. Se a pessoa ficar muito tempo nessa posição, pode ter danos permanentes, como lesões no nervo periférico e lesões vasculares. ${ }^{299}$

No procedimento denominado suspensão, o método mais simples é pendurar a vítima pelos pulsos amarrados na frente do tronco. Se examinada tão logo haverá marcas nos pulsos. Por anos, a pessoa pode sentir dor ao levantar os braços, segurar pesos, pentear o cabelo etc. O pau de arara, muito comum na América Latina, consistia em prender os pulsos na frente do corpo, os braços passados por cima dos joelhos e um pau atrás dos mesmos, o ferimento decorrente dessa prática é a ruptura dos ligamentos e danos vasculares abaixo dos joelhos. ${ }^{300}$

Para o quase asfixiamento de uma vítima, usa-se o método "submarino", um apelido de origem latino-americana. A cabeça é imersa na água por minutos, até que comece o afogamento, em seguida, tiram-na do tanque por um tempo e repete-se a sequência algumas vezes, inclusive, em determinadas ocasiões a prática se dá com a vítima

\footnotetext{
${ }^{297}$ FORREST, D., op.cit., p. 162.

${ }^{298}$ FORREST, D., op.cit., p. 163.

${ }^{299}$ FORREST, D., op.cit., p. 163.

${ }^{300}$ FORREST, D., op.cit., p. 164.
} 
suspensa pelos calcanhares. O "submarino seco", por outro lado, consiste em amarrar um saco plástico na cabeça da vítima e prender bem justo no pescoço, é comum acrescer algum material contaminado ou irritante, por exemplo, pó de chilli. Os efeitos mais imediatos são os problemas respiratórios. Conjuntivite e otite também podem configurar sinais do "submarino". Dentre os efeitos a longo-prazo cita-se aquisição de asma e bronquite, ambos em indivíduos que não apresentavam esses problemas antes. ${ }^{301}$

O médico investigativo que omite examinar um presidiário se volta conivente com o crime de tortura. No Iraque, por exemplo, um profissional de saúde, após analisar a mandíbula fraturada de um preso, criou uma explicação pouco convincente aos investigadores que visitavam a instituição, ademais, ele não pediu para o paciente remover a camisa a fim de procurar por mais sinais de violência. Do mesmo modo precário que eram realizados os exames, não raro as fichas médicas eram perdidas. ${ }^{302}$

São muitas as formas de se distorcer o papel médico que de "benéfico" passa a ser considerado "maléfico". Devido à importância dos exames físicos para os processos de julgamento, resta a esperança de que sejam devidamente conduzidos e em relação à cumplicidade médica com a tortura espera-se que não passe de um capítulo da história do século XXI.

\section{e) Possíveis explicações para o comportamento dos médicos}

Ao tomar conhecimento sobre a recente guerra contra o terror instaurada pelos EUA e sobre o envolvimento de médicos, pode a pessoa se perguntar: como conseguiram? Considerando um dos princípios de sua profissão, baseado em "fazer o bem", como é possível distanciar seus respectivos valores e ser capaz dos feitos cometidos?

Primeiro, é importante pensar que as "técnicas reforçadas de interrogatório" foram uma política adotada pela administração Bush, por isso se torna uma prática "legal" e não "tortura". Ingenuamente pode-se imaginar que um médico, confuso sobre os limites dessas técnicas, não enxergaria crueldade em suas condutas.

Além disso, quando uma pessoa se encontra em terras estrangeiras, seus valores morais sofrem relativização, especialmente em um ambiente em que se entende a violência

\footnotetext{
${ }^{301}$ FORREST, D., op.cit., p. 168.

${ }^{302}$ MILES, S. H., op. cit., p. 123.
} 
como uma regra. Assim, a pressão sobre esses profissionais pode desenvolver um grau de tolerância aos abusos cometidos. ${ }^{303}$

Em sua formação, os médicos são preparados para considerar o bem-estar do paciente em primeira instância, não importa o local e as condições. Entretanto, não se pode esquecer que esses profissionais são acima de tudo seres humanos e estão suscetíveis às questões situacionais que influenciam seu pensamento e comportamento. Pesquisas de psicologia social mostram que o comportamento humano é profundamente afetado pelo ambiente que a pessoa está inserida. ${ }^{304}$

Em um famoso estudo realizado pelo psicólogo Philip Zimbardo, na Universidade de Stanford, demonstra-se que o ambiente de um centro de detenção pode conduzir pessoas "normais" a se engajarem ou tolerarem abusos aos detentos. Em 1971, Zimbardo recrutou 24 estudantes universitários, divididos aleatoriamente entre "presos" e "guardas", e observou o comportamento deles na medida em que desempenhavam seus papéis na prisão simulada. A pesquisa duraria duas semanas, mas após seis dias fez-se necessário encerrála, pois os "guardas" encarnaram o papel seriamente, ao ponto de exibirem um comportamento sádico e desumano, de modo que os "presos" sofreram colapsos emocionais. ${ }^{305}$ Alguns dos guardas revelaram um sentimento de desconforto em relação ao ocorrido com os presos, no entanto, nenhum deles impediu seus colegas de cometerem abusos. Assim, esse estudo evidencia que um profissional de saúde, também com a incumbência de desempenhar um papel militar, poderia perder sua missão de curar o paciente, priorizando suas obrigações como soldado. Além disso, os estresses de uma guerra diminuem os recursos cognitivos individuais a um nível moralmente desastroso. ${ }^{306}$

Um médico que se recusa a participar dos abusos terá de lidar com as importunações e pressões dos companheiros influenciados pela ideia de que o profissional que se opõe a colaborar com técnicas mais agressivas de interrogatório é "sensível" demais para operar no campo. Em outras palavras, aquele que se compromete a respeitar os Direitos Humanos é considerado idealista por não aceitar a realidade tal qual. Se essa enorme campanha não suavizar as noções humanitárias do indivíduo, ele será enviado para

\footnotetext{
${ }^{303}$ BREWER, S.E.; ARRIGO, J.M., "Places that medical ethics can`t find: Preliminary observations on why health professionals fail to stop torture in overseas counterterrorism operations", In: Interrogations, forced feedings, and the role of health professionals: New perspectives on international human rights, humanitarian law, and ethics, Edited by Ryan Goodman and Mindy Jane Roseman, Human Rights Program, Harvard Law School, Cambridge, Massachusetts, United States, Signature Book Printing, 2009, p. 1.

${ }^{304}$ BREWER, S.E.; ARRIGO, J.M., op.cit., p. 3.

${ }^{305}$ BREWER, S.E.; ARRIGO, J.M., op.cit., p. 4.

${ }^{306}$ BREWER, S.E.; ARRIGO, J.M., op.cit., p. 5.
} 
casa, garantindo a constituição de um time médico segundo os ideais da Central de Inteligência. ${ }^{307}$

Ademais, uma forma de convencer os médicos a cooperarem com os abusos é convencê-los de que os detentos são suspeitos de manterem laços fortes com atividades terroristas:

[S]ome of our medical personnel are aiding us more after I take them to see terrorist crime scenes. The psych guys are coming around as they cannot imagine a local [person] planning and directing an act designed to kill women and children of their own culture. (BREWER; ARRIGO, 2009, p. $10)^{308}$

Desse modo, após essas visitas aos locais de ataques terroristas, os profissionais de saúde não conseguem manter a mesma neutralidade durante os cuidados dispensados aos detentos. Apesar da ausência de uma correlação específica entre o ato e a pessoa, a noção generalizada de que esses detentos pertencem a uma cultura de indivíduos violentos, sem apreço pela vida humana já se encontra impregnada. ${ }^{309}$

Além dessas formas de manipulação, há outra maneira de pressionar os médicos militares. A maioria deles recebeu bolsa de estudos do Exército para cursar a Faculdade de Medicina, caso recusem a defender e apoiar o Exército, terão de responder às acusações de insubordinação em Cortes internas e seriam obrigados a restituir aos militares o valor gasto em seus estudos. Por isso o Exército escolhe médicos jovens, recém-formados, pois a simples sugestão de terem de pagar por sua educação alteram seu comportamento e imparcialidade. Solicita-se também que o médico, investido dos princípios éticos da Medicina, confie sua lealdade ao país. ${ }^{310}$

Muitas vezes, o profissional se sente melhor em recusar o tratamento médico ao detento para que ele coopere. Parece ser um método mais humano, assim como o resgate do detento para encerrar seu sofrimento em troca de informações. ${ }^{311}$

Portanto, para um médico auxiliar ou se calar no que diz respeito à tortura combinase o argumento de que as normas não são tão relevantes no exterior à sensação de isolamento da realidade e à lavagem cerebral por meio de ideias militares. Esse cenário

\footnotetext{
${ }^{307}$ BREWER, S.E.; ARRIGO, J.M., op.cit., p. 8.

${ }^{308}$ Tradução da autora:" Alguns da nossa equipe médica estão ajudando mais depois que eu os levei para ver cenas de crime de atos terroristas. Os rapazes da psico estão mudando de ideia, já que não imaginam um local [pessoa] planejando e dirigindo um ato projetado para matar mulheres e crianças de sua própria cultura".

${ }^{309}$ BREWER, S.E.; ARRIGO, J.M., op.cit., p. 10.

${ }^{310}$ BREWER, S.E.; ARRIGO, J.M., op.cit., p. 11.

${ }^{311}$ BREWER, S.E.; ARRIGO, J.M., op.cit., p. 12.
} 
pode ser muito pior em centros de detenção secretos, "não oficiais", em barcos ou outros locais onde grupos de Direitos Humanos não tenham acesso. Isso permite que os Estados Unidos tornem inacessível o número de presos e consigam obter informações a sua maneira. ${ }^{312}$

A mera presença de um médico em uma sala de interrogatório pode piorar muito as condições para o detento. Alguns interrogadores se sentem com uma falsa sensação de segurança, pois caso a situação fuja do controle, a saúde do interrogado deve ser salvaguardada pelo médico, é sua obrigação prever e evitar o mal. Diante disso, a sessão de tortura pode se tornar intensa e o profissional de saúde que examina um detento antes de um interrogatório acaba por exercer um lado perverso da Medicina, justamente por confirmar se o paciente está saudável e apto para ser submetido à tortura, em outras palavras, o médico assina o atestado que legitima a atitude cruel por parte do interrogador. $^{313}$

Jonathan H. Marks concorda com Jean Maria Arrigo ao destacar que após o "11 de setembro", na falta de interrogadores, o governo americano passou a recrutar rapazes a partir de 19 anos para cumprirem o serviço de interrogadores seniores. Muitos, na impossibilidade de pagarem o curso Medicina, se viram atraídos pela oferta de bolsas de estudo e pela oportunidade de ajudar seu país em um momento tão crítico. O arrefecimento dos Direitos Humanos garantiria a segurança do mundo naquele momento. ${ }^{314}$

Outra questão a ser pensada é a relação entre soldados e médicos. Os médicos militares não são percebidos como "soldados", eles usam o sinal do "caduceu" na roupa para indicar justamente que não são combatentes. Em razão da Convenção de Genebra, esse símbolo garante a eles privilégios e proteções de acordo com as leis da guerra, entretanto, quando um médico se torna parte do grupo de inteligência como consultor de comportamento, concomitantemente, ele perde o status de "não combatente" do Direito Internacional e recebe a aceitação dos colegas e da comunidade de inteligência. Isso pode provocar o desejo de se tornar um dos agentes de inteligência e não somente um consultor de comportamento. ${ }^{315}$ Ao sentir-se integrante do time, o médico se autoconsidera um

\footnotetext{
${ }^{312}$ BREWER, S.E.; ARRIGO, J.M., op.cit., p. 13.

${ }^{313}$ BREWER, S.E.; ARRIGO, J.M., op.cit., p. 14.

314 MARKS, J.H., "Looking Back, Thinking Ahead: the Complicity of Health Professionals in Detainee Abuse", In: Interrogations, forced feedings, and the role of health professionals: New perspectives on international human rights, humanitarian law, and ethics, Edited by Ryan Goodman and Mindy Jane Roseman, Human Rights Program, Harvard Law School, Cambridge, Massachusetts, United States, Signature Book Printing, 2009, p. 29.

${ }^{315}$ MARKS, J.H., op.cit., p. 30.
} 
soldado e, além de extrapolar suas funções, se perde no que se refere ao limite do certo e do errado. A identificação desse profissional com os ideais dos militares ocasionou problemas éticos já na Segunda Guerra Mundial, nessa conjuntura o médico cumpre em primeiro plano o seu papel de "soldado".

Em artigo do Dr. Robert J. Lifton ${ }^{316}$, observa-se sua opinião sobre o que aconteceu com os médicos militares americanos:

The doctors thus brought a medical component to what I call an "atrocityproducing situation" - one so structured, psychologically and militarily, that ordinary people can readily engage in atrocities. Even without directly participating in the abuse, doctors may have become socialized to an environment of torture and by virtue of their medical authority helped sustain it. In studying various forms of medical abuse, I have found that the participation of doctors can confer an aura of legitimacy and can even create an illusion of therapy and healing. (LIFTON, $2004)^{317}$

Um médico envolvido nesse ambiente de tortura dá a "chancela", a aprovação de um comportamento tido como adequado. O detento está saudável para a sessão de perguntas, se algo der errado o médico irá curá-lo. Tudo é permitido e está conforme as leis. Mesmo assim, em 2006, a Associação Médica Americana, a Associação Americana de Psiquiatria e a Associação Médica Mundial divulgaram políticas que vetavam o auxílio médico ou sua participação em interrogatórios, fato que não coibiu o envolvimento de alguns médicos. ${ }^{318}$

Outra forma de cumplicidade com esses abusos pode ocorrer entre os próprios médicos. Caso um diagnóstico a respeito de um detento seja concluído equivocadamente por um superior hierárquico, o médico subordinado não irá contestá-lo, de modo a ocultar abusos ou prejudicar o detento afirmando que sua saúde está em ordem, quando na verdade não ele está apto para enfrentar um interrogatório. ${ }^{319}$ Ademais, o mentor nunca deveria

\footnotetext{
${ }^{316}$ LIFTON, R.J., "Doctors and Torture”, The New England Journal Of Medicine, pp. 351-355, 29 July 2004. Disponível em: <http://www.nejm.org/doi/full/10.1056/NEJMp048065\#t=article> . Acesso em: 17 jul. 2011.

317 Tradução da autora: Os médicos trouxeram, então, um componente médico que eu chamo de "situação produtora de atrocidades" - uma tão estruturada, psicologicamente e militarmente, que pessoas comuns estariam prontas para engajar em atrocidades. Mesmo sem participar diretamente dos abusos, eles podem ter se sentido socializados em um ambiente de tortura, e pela virtude de sua autoridade médica ajudaram a sustentá-la. Ao estudar várias formas de abuso médico, descobri que a participação dos médicos pode conferir uma aura de legitimidade e até mesmo criar uma ilusão de terapia e cura.

${ }^{318}$ MARKS, J.H., op.cit., p. 32.

${ }^{319}$ MARKS, J.H., op.cit., p. 33.
} 
subestimar a ética, tal fato constitui um mau exemplo e propicia uma liberdade aos outros médicos para cometerem os mesmos abusos. ${ }^{320}$

Uma teoria explicada por Leonard S. Rubenstein afirma que os médicos encontraram formas de racionalizar sua cumplicidade com a tortura, colocando-se como protetores dos detentos. O Departamento de Defesa americano estimula essa ideia ao corroborar o apoio médico em um interrogatório, em outras palavras, cuidando dos ferimentos do detento, o médico atua tradicionalmente no seu papel beneficente. Essa ilusão significou danos aos detentos e à profissão médica. ${ }^{321}$

Parte da ilusão está em se agarrar à noção de que procura melhorar o bem-estar dos detentos. Em circunstâncias de espancamento durante o interrogatório, o médico irá cuidar dos ferimentos, mesmo que isso signifique o retorno para mais perguntas ou, ainda, se o detento faz greve de fome, irá amarrá-lo e alimentá-lo à força para preservar sua vida. Assim, os médicos enxergavam o seu papel de beneficência, mas ignoravam o mais importante: não evitavam a causa dos males dos detentos, não denunciavam os abusos e aconselhavam como provocar dor em um interrogatório. $\mathrm{O}$ cenário os embruteceu e os fazia pensar que sua mera presença amenizava as condições duras dos detentos. ${ }^{322}$

O médico militar tem uma dupla lealdade, com seu paciente e com o serviço de inteligência que, costumeiramente, prevalecia. Rubenstein não acredita que os médicos teriam conseguido evitar os abusos, pelo simples fato de não possuírem autoridade para tanto. Somente uma estrutura institucional conseguiria evitar isso, permitindo que o médico priorizasse sua ética. ${ }^{323}$

Marks concorda com esse posicionamento e vai além, segundo ele os médicos que denunciam as práticas abusivas deveriam ser encorajados e recompensados, o que não significa a exposição desses profissionais, isso lhes traria muitos riscos. Se um delator tem receio de destruir sua carreira ou apresentar alguma dívida, essas consequências deveriam ser amenizadas, para estimular e ajudar os que realmente almejam por um fim aos abusos cometidos. $^{324}$ É um ato de coragem questionar e denunciar toda uma estrutura em que se está inserido.

\footnotetext{
${ }^{320}$ MARKS, J.H., op.cit., p. 45.

${ }^{321}$ RUBENSTEIN, L.S., "Complicity and the Illusion of Beneficence", In: Interrogations, forced feedings, and the role of health professionals: New perspectives on international human rights, humanitarian law, and ethics, Edited by Ryan Goodman and Mindy Jane Roseman, Human Rights Program, Harvard Law School, Cambridge, Massachusetts, United States, Signature Book Printing, 2009, p. 51.

${ }^{322}$ RUBENSTEIN, L.S., op.cit., p. 67.

${ }^{323}$ RUBENSTEIN, L.S., op.cit., p. 70.

${ }^{324}$ MARKS, J.H., op.cit., p. 45.
} 
Por fim, os médicos envolvidos com tortura assim o fizeram, pois sabiam sobre a ausência de punição, no entanto, todos os envolvidos deveriam ser responsabilizados por seus atos. As associações e as juntas médicas necessitam se unir para puni-los disciplinarmente. A sociedade e os ativistas dos Direitos Humanos podem divulgar as informações e os nomes dos envolvidos no abuso de detentos a modo de cumprirem uma justiça informal, conscientizando a população e na esperança de que esses atos não continuem impunes. ${ }^{325}$

Alguns passos já foram tomados. Em abril de 2011 divulgou-se o julgamento na Corte Suprema do Estado de Nova York do Dr. John Leso, psicólogo que esteve envolvido no interrogatório de Al-Qahtani (citado anteriormente) e em práticas de tortura na base de Guantánamo, a denúncia foi feita pelo Dr. Steven Reisner, outro psicólogo. A esperança é a de que o Dr. Leso tenha sua licença profissional cassada, ${ }^{326}$ de modo que os médicos envolvidos sejam responsabilizados em um futuro próximo por sua participação na guerra contra o terror.

\section{f) Relatório da CIA}

Este item pretende analisar um arquivo confidencial da Agência Central de Inteligência (CIA) divulgado pela União Americana de Liberdades Civis (ACLU, na sigla em inglês), que venceu uma ação exigindo a sua respectiva quebra de sigilo, em agosto de 2009. Trata-se de um relatório escrito pelo então inspetor-geral da CIA, cujo conteúdo inclui a discussão com o Departamento de Justiça americano a respeito do endurecimento das táticas de interrogatório pelo Centro de Contraterrorismo, a aprovação legal do Departamento de Justiça e algumas passagens da experiência em si. Ao final, em um dos apêndices do relatório, há diretrizes sobre os serviços médicos prestados como apoio nos interrogatórios dos detentos, do período de setembro de 2001 a outubro de 2003 . $^{327}$

\footnotetext{
${ }^{325}$ MARKS, J.H., op.cit., p. 46.

${ }^{326}$ Site Democracy Now. Disponível em:

$<$ http://www.democracynow.org/blog/2011/4/6/one_guantanamo_trial_that_will_be_held_in_new_york $>$. Acesso em: 17 jul. 2011.

327 CENTRAL INTELLIGENCE AGENCY, Office of Inspector General. Draft Office of Medical Services Guidelines on Medical and Psychological Support to Detainee Interrogations (2003) Special Review. Counterterrorism Detention and Interrogation Activities. Central Intelligence Agency. Disponível em: $<$ http://www.gwu.edu/ nsarchiv/torture archive/20040507.pdf $>$. Acesso em: 20 jan. 2012.
} 
Da leitura íntegra desse documento, apesar das inúmeras passagens cobertas por tarjas pretas, percebe-se que se trata de um relatório a respeito do Centro de Contraterrorismo e sua investida em um método de interrogar detentos terroristas em locais estrangeiros. A ideia inicial era aprimorar os métodos por meio de um caso específico, o do detento Abu Zubaydah, capturado em 27 de março de 2002, suposto integrante do alto escalão da Al-Qaeda, considerava-se que ele detinha informações muito relevantes para evitar futuros ataques terroristas. Antes do início dos interrogatórios, o prisioneiro foi tratado por médicos, devido às inúmeras lesões sofridas em sua captura, portanto, foi necessário aguardar sua recuperação. ${ }^{328}$

Inspirados pelos resultados do programa Sobreviver, Evadir, Resistir, Escapar (SERE, em inglês Survival, Evasion, Resistance, Escape), pelo treinamento das Forças Armadas e pelos serviços de inteligência, todos relacionados ao modo de se portar quando capturados, se pretendia descobrir quais atos poderiam ser considerados "tortura" e, portanto, violadores das Convenções assinadas pelo governo norte-americano, dentre elas a principal é a Convenção Contra Tortura e Outros Tratamentos ou Penas Cruéis, Desumanas ou Degradantes, implementada no Código Criminal dos Estados Unidos por meio do artigo 18 U.S.C. 2340-2340A. ${ }^{329}$ A partir dessa resolução, essa prática significaria um desrespeito à Lei Federal e às convenções contra tortura.

A questão foi levada ao Departamento de Justiça americano para um parecer, emitido em 01 de agosto de 2002, e que se encontra, na íntegra, em um apêndice do relatório da Central de Inteligência. Segundo o documento as opiniões se referem somente ao caso do preso Zubaydah. ${ }^{330}$ Por meio dele concluiu-se que as "técnicas reforçadas de interrogatório" não constituiriam um método digno de causar "sofrimento" e "dor", conforme o entendimento do Procurador-geral adjunto, Jay S. Bybee. De acordo com ele, para se constatar violação ao artigo 18 U.S.C. 2340 é essencial pensar o ato de tortura somente nos casos em que o sujeito é submetido às técnicas por um período prolongado, de modo a provocar sofrimento e dor severa, difícil de suportar, além de um consequente e estável dano mental. ${ }^{331} \mathrm{O}$ convencimento de que as técnicas não causariam danos mentais repousa no sucesso das medidas SERE, por meio das quais em dez mil alunos, ao longo de dez anos, não foram diagnosticados casos de problemas mentais aos que receberam o

\footnotetext{
${ }^{328}$ CENTRAL INTELLIGENCE AGENCY, op.cit., p. 13.

${ }^{329}$ CENTRAL INTELLIGENCE AGENCY, op.cit., p. 16.

${ }^{330}$ CENTRAL INTELLIGENCE AGENCY, op.cit., Appendix C, p. 1.

${ }^{331}$ CENTRAL INTELLIGENCE AGENCY, op.cit., Appendix C, p. 10.
} 
treinamento. ${ }^{332}$ No relatório de Bybee é corroborado obrigatória a presença de médicos especialistas na realização dos procedimentos coercitivos. ${ }^{333}$

Primeiro, o médico deve examinar o detento para avaliar sua condição de saúde. ${ }^{334}$ As técnicas reforçadas de interrogatório conformariam o seguinte: segurar o detento pelo pescoço com ambas as mãos de forma controlada, empurrá-lo contra uma parede "falsa", segurar o seu rosto, desferir tapas com a mão aberta, confiná-lo em caixa apertada por período controlado e inserir insetos dentro dela, mantê-lo parado em posições cansativas, que provocam estresse, privação de sono controlada e, finalmente, a prática do "waterboarding", ou seja, o afogamento simulado. ${ }^{335}$ Para todas essas modalidades, Bybee apresentou justificativas que as permitiam. O importante era não machucar de forma intencional, mas apenas intimidar. ${ }^{336}$ Conforme o artigo 18 U.S.C. 2340, do Código Criminal americano, o envolvido em um crime de tortura pode ser penalizado em até 20 anos de prisão ou pena de morte, caso a tortura resulte em óbito da vítima. ${ }^{337} \mathrm{~A}$ jurisdição desse artigo compromete qualquer cidadão americano, em qualquer estado, ou qualquer pessoa, estrangeira ou não, em território norte-americano. A partir do exposto, conclui-se que os Estados Unidos condenam a prática de tortura, entretanto, criam inúmeras "versões" para determinar o que se enquadra em seu "particular" conceito de tortura.

Por exemplo, a dor física, umas das evidências da tortura, precisa causar danos a algum órgão interno, uma alteração mental significativa, a perda de alguma função motora ou orgânica e a morte. ${ }^{338}$ Do exposto pela CIA como ações a serem tomadas, de forma controlada e não repetitiva, Bybee concluiu que as técnicas reforçadas de interrogatório não seriam consideradas torturas e não violariam a Convenção Contra Tortura, logo, tais atos não seriam alvo da jurisdição do Tribunal Penal Internacional. ${ }^{339}$ Essa passagem se mostra extremamente interessante, já que os EUA não ratificaram o Estatuto de Roma e não teriam de temer o TPI. Aparentemente, mesmo em um relatório cujo intuito primeiro era apenas de comunicação interna da Central de Inteligência americana, há essa preocupação pelo não cometimento de crimes internacionais e pelo receio de ter de se submeter à Corte do TPI.

\footnotetext{
${ }^{332}$ CENTRAL INTELLIGENCE AGENCY, op.cit., Appendix C, p. 5.

${ }^{333}$ CENTRAL INTELLIGENCE AGENCY, op.cit., Appendix C, p. 4.

${ }^{334}$ CENTRAL INTELLIGENCE AGENCY, op.cit., p. 14.

${ }^{335}$ CENTRAL INTELLIGENCE AGENCY, op.cit., p. 15.

${ }^{336}$ CENTRAL INTELLIGENCE AGENCY, op.cit., p. 16.

${ }^{337}$ CENTRAL INTELLIGENCE AGENCY, op.cit., p. 18.

${ }^{338}$ CENTRAL INTELLIGENCE AGENCY, op.cit., p. 19.

${ }^{339}$ CENTRAL INTELLIGENCE AGENCY, op.cit., p. 20.
} 
Das justificativas de Bybee, os atos não seriam degradantes nem punitivos (violação à Convenção) $^{340}$, por exemplo, as posições estressoras apenas geram fadiga muscular, a qual não configura dor insuportável, de modo que poderiam ser usadas. A caixa de confinamento foi liberada, pois por tempo controlado não causa sofrimento nem dor. A inserção de um inseto inofensivo no interior da caixa foi liberada apenas para causar medo. Tapas no rosto e empurrões contra paredes são liberados, porque são empregados como um fator surpresa, para causar "susto" e não machucar de verdade. ${ }^{341} \mathrm{O}$ afogamento simulado, que consiste em jogar água em um preso deitado, com pano sobre o rosto, também era permitido, sua prática não figura um verdadeiro risco de afogamento, além de o sofrimento não existir. Os intervalos entre os golpes de água não superam 40 segundos e o alívio proporcionado nesse período evita o sofrimento, o intuito é produzir na vítima uma sensação fisiológica de afogamento, a fim de assustar e intimidar. Em relação ao afogamento simulado, aponta-se o fato de não causar dano mental, porém o seu emprego deve ser a última opção e realizado de forma muito controlada. ${ }^{342} \mathrm{O}$ interessante é constatar que as ameaças de morte foram vetadas, pois apesar de serem uma violência verbal configurariam tortura, ao passo que apenas as "simulações de medo" não são consideradas tortura. ${ }^{343}$

O médico tem o dever de interromper as táticas de interrogatório caso perceba que o detento sofrerá dor física severa. ${ }^{344}$ Outra restrição no que se refere à privação de sono, é caracterizada pelo extremo controle durante a sua prática, pois está apta a causar danos mentais. ${ }^{345}$

Médicos e psicólogos deveriam monitorar as sessões de interrogatório, para as quais foram estabelecidas diretrizes médicas, censuradas com tarjas pretas. ${ }^{346}$ Comenta-se no relatório que as ações usadas se diferenciavam dos treinamentos, portanto, as técnicas reforçadas de interrogatório não foram aplicadas de forma controlada. ${ }^{347}$ Todas elas dependiam de aprovação prévia do quartel-general que não raro era dispensada e aplicavase qualquer técnica, inclusive inéditas, de maneira improvisada, com uso de algemas e

\footnotetext{
${ }^{340}$ CENTRAL INTELLIGENCE AGENCY, op.cit., p. 17.

${ }^{341}$ CENTRAL INTELLIGENCE AGENCY, op.cit., Appendix C, p. 11.

${ }^{342}$ CENTRAL INTELLIGENCE AGENCY, op.cit., Appendix C, p. 11.

${ }^{343}$ CENTRAL INTELLIGENCE AGENCY, op.cit., Appendix C, p. 13.

${ }^{344}$ CENTRAL INTELLIGENCE AGENCY, op.cit., Appendix C, p. 16.

${ }^{345}$ CENTRAL INTELLIGENCE AGENCY, op.cit., Appendix C, p. 18.

${ }^{346}$ CENTRAL INTELLIGENCE AGENCY, op.cit., p. 30.

${ }^{347}$ CENTRAL INTELLIGENCE AGENCY, op.cit., p. 37.
} 
alguns castigos, como banhos frios em salas refrigeradas, uso de escovas de cerdas duras para esfregar ferimentos, ameaças de morte com armas de fogo ou furadeira elétrica. ${ }^{348}$

Ao longo do relatório afirma-se que o programa teve sucesso na obtenção de informações que abortaram o planejamento de atos terroristas. Entretanto, havia questionamentos sobre o fato de esse sucesso estar diretamente ligado a eficácia das técnicas reforçadas de interrogatório. Segundo o texto o uso de técnicas improvisadas certamente comprometeu a integridade da experiência do centro de contraterrorismo. ${ }^{349}$ Inclusive, alguns oficiais da agência expressaram preocupação de que no futuro seus atos seriam alvo de perseguição de grupos de Direitos Humanos. Existe até mesmo alusão de um oficial de que em dez anos se arrependeriam de suas condutas e estariam na lista de alguma Corte mundial para crimes de guerra. ${ }^{350}$ Portanto, há praticamente um consenso: apesar de a "terminologia" não enquadrar os atos como de tortura, todos os envolvidos concordavam que se tratava, sim, de tortura. O uso de um parecer do Departamento de Justiça atestando a legalidade das condutas não afastaria a responsabilidade de ninguém.

Ao final do relatório, no apêndice $\mathrm{F}$, se encontra as diretrizes aos médicos que acompanhariam as sessões de interrogatório utilizando as técnicas padrões e as técnicas reforçadas. As primeiras consistiam em: raspagem de pelos, remoção da roupa, uso de capuz e de fraldas por até 72 horas, isolamento, música alta, luz forte, ambiente refrigerado em excesso, dieta restritiva de calorias, uso de algemas, privação de sono etc. ${ }^{351}$ As diretrizes médicas deveriam ser aplicadas no período inicial de interrogatório, no desenrolar do mesmo e em uma terceira situação coberta por uma tarja preta, ${ }^{352}$ presume-se que seja o cuidado médico para ocultar no detento os ferimentos causados pelo interrogatório, ou pior, o auxílio direto do médico durante o mesmo.

Os médicos são orientados para aplicarem as técnicas com intuito psicológico, sem provocar danos físicos e mentais. Portanto, os médicos devem monitorar tudo, por exemplo, ao administrarem tapas, os dedos devem estar abertos para a dor ser irrelevante e causar apenas choque e surpresa ao prisioneiro. ${ }^{353}$

Em relação ao exame médico de entrada, é descrito que o profissional deve descobrir doenças pré-existentes, colher sangue e prosseguir com exames periódicos,

\footnotetext{
${ }^{348}$ CENTRAL INTELLIGENCE AGENCY, op.cit., p. 41.

${ }^{349}$ CENTRAL INTELLIGENCE AGENCY, op.cit., p. 85.

${ }^{350}$ CENTRAL INTELLIGENCE AGENCY, op.cit., p. 94.

${ }^{351}$ CENTRAL INTELLIGENCE AGENCY, op.cit., Appendix F, p. 1.

${ }^{352}$ CENTRAL INTELLIGENCE AGENCY, op.cit., Appendix F, p. 1.

${ }^{353}$ CENTRAL INTELLIGENCE AGENCY, op.cit., Appendix F, p. 2.
} 
devendo todos esses aspectos constarem nos laudos, inclusive, que "não há evidências físicas" de agressão. O exame médico foi descrito em três linhas, o conteúdo restante, que consiste de três parágrafos, foi coberto por tarjas pretas. ${ }^{354}$

Cita-se que o detento terá direito ao tratamento médico de suas enfermidades e receberá remédios se necessário, outras recomendações estão veladas por tarjas. ${ }^{355} \mathrm{~A}$ comida deve oferecer o mínimo de nutrientes e líquidos, os detentos que se recusarem a beber e comer serão forçados a tal. Em ambientes refrigerados, os médicos devem monitorar quando as temperaturas estiverem abaixo dos $18^{\circ} \mathrm{C}$, evitando a hipotermia, mais detalhes são cobertos por tarjas pretas. ${ }^{356}$ Em relação à música alta, uso de algemas, privação de sono e caixa de confinamento, praticamente tudo foi censurado. ${ }^{357}$ A prática de afogamento simulado é bem descrita, além disso, ratifica-se o fato de no Programa SERE não haver riscos médicos. Segue uma enorme tarja preta e a afirmação que, caso o detento desmaie durante a prática, o médico deve intervir. Tendo em vista as várias reações dos prisioneiros, é impossível prever como cada indivíduo responderá à técnica. ${ }^{358}$ Explica-se também que tudo deve ser extremamente bem documentado, ademais o uso prolongado do afogamento simulado é medicamente contraindicado. ${ }^{359}$ A página seguinte é totalmente oculta por tarjas pretas.

Portanto, apesar da cautela, os envolvidos sabiam que essas técnicas eram questionáveis, tinham consciência sobre o duvidoso sucesso e que na maior parte dos casos seu emprego se deu de maneira descontrolada e desmedida. Os médicos estiveram presentes e, a julgar pela quantidade de tarjas pretas, diretamente envolvidos na prática e dissimulação da tortura. Não suficiente, deveria existir uma atmosfera de tranquilidade por não oferecer tratamento ao preso de guerra segundo a Convenção de Genebra. Conforme mencionado, esses presos não pertenciam às Forças Armadas oficiais desses países, logo não possuíam status de "presos de guerra", servindo de "carta branca" aos norteamericanos para obterem informações a todo e qualquer custo.

Antes do relatório ser divulgado pela imprensa, em 2009, o então diretor da CIA, Leon E. Panetta, fez uma declaração de que todas as ações eram atos passados, além disso, os envolvidos seriam punidos disciplinarmente, mas a discussão sobre a legalidade ou não

\footnotetext{
${ }^{354}$ CENTRAL INTELLIGENCE AGENCY, op.cit., Appendix F, p. 3.

${ }^{355}$ CENTRAL INTELLIGENCE AGENCY, op.cit., Appendix F, p. 3.

${ }^{356}$ CENTRAL INTELLIGENCE AGENCY, op.cit., Appendix F, p. 4.

${ }^{357}$ CENTRAL INTELLIGENCE AGENCY, op.cit., Appendix F, p. 7.

${ }^{358}$ CENTRAL INTELLIGENCE AGENCY, op.cit., Appendix F, p. 9.

${ }^{359}$ CENTRAL INTELLIGENCE AGENCY, op.cit., Appendix F, p. 10.
} 
para obtenção de informações, não seria pauta. Para ele, o foco deveria ser o presente, pois o importante era a prática da tortura não formar parte da realidade contemporânea. ${ }^{360} \mathrm{Em}$ outras palavras, afastou por completo a apuração dos fatos e sua devida criminalização. Resta saber se no futuro, os responsáveis responderão por seus atos.

O presidente Barack Obama, por outro lado, desde que assumiu o poder e tomou conhecimento dessas prisões secretas e suas respectivas práticas de abuso, as condenou, caracterizando-as de "tortura". Uma de suas promessas era o fechamento de Guantánamo em um ano, no entanto, tal fato ainda não se concretizou. Em 2009, foi severamente instruído que a CIA somente faça uso de métodos de investigação aprovados pelo Exército Americano. Entretanto, a ideia de instaurar uma comissão de inquérito para apurar a conjuntura das prisões foi recebida de forma fria, mas não afastada por completo, uma vez que ninguém está acima da lei. Porém, o presidente Obama também afirmou estar “mais interessado em olhar para frente do que para trás". ${ }^{361}$ Já em 2012 e considerando que, todavia, a apuração e a investigação desses crimes não foram trazidas à luz, permanecem as inquietações sobre a justiça e as possíveis mudanças, ou se será mais um caso de impunidade para a história.

\section{g) Relatório da Cruz Vermelha}

Mark Danner, escritor americano e professor da Universidade da Califórnia, em Berkeley, foi o responsável por divulgar em abril de 2009 um relatório do Comitê Internacional da Cruz Vermelha (International Committe of the Red Cross - ICRC) que revelou a existência de sessões de tortura em prisões da CIA e ratificou o envolvimento médico nos referidos abusos. ${ }^{362}$

A Cruz Vermelha é uma entidade que se preocupa com o direito humanitário e desde 2002 questiona os Estados Unidos a respeito de presos, oriundos da guerra contra o terror, que estariam sobre sua custódia. O relatório em questão analisou 14 detentos considerados de "alto valor", no presídio de Guantánamo, em Cuba, em setembro de 2006.

\footnotetext{
${ }^{360}$ Site de notícias TPR. Disponível em: $<$ http://pubrecord.org/torture/3920/panetta-report-torture-oldstory/>. Acesso em: 21 jan. 2012.

${ }^{361}$ Site Folha de S.Paulo. Disponível em: < http://www1.folha.uol.com.br/folha/mundo/ult94u535354.shtml>. Acesso em: 22 jan. 2012.

${ }^{362}$ Site do New York Times. Disponível em: <http://www.nytimes.com/2009/04/07/world/07detain.html>. Acesso em: 21 jan. 2012.
} 
Realizaram-se entrevistas individuais com os presos, nos meses de outubro e dezembro desse mesmo ano. O relatório foi finalizado em fevereiro de $2007 .^{363}$

O procedimento "padrão" outorgado a esses presos consistiu na captura, mudança de país, interrogatórios violentos e completa alienação ao mundo externo. Os métodos utilizados e descritos no relatório, confirmam o uso das técnicas reforçadas de interrogatório exploradas no Relatório da CIA (item anterior).

O detento Khaled Shaik Mohammed, submetido ao afogamento simulado, afirma que durante o procedimento teve um aparelho acoplado ao seu dedo, constantemente verificado por uma pessoa que ele presume ser um médico. Pela descrição parece tratar-se de um oxímetro de pulso, aparelho médico que avalia a saturação de oxigênio no sangue. ${ }^{364}$

Segundo relato de Bin Attash, prisioneiro obrigado à posições estressoras, era comum que suas pernas inchassem, sendo verificadas frequentemente por médicos americanos. $^{365}$

Também se descreve que quase todos os detentos foram submetidos a períodos prolongados sem roupas, a nudez constituía um modo de piorar as condições de frio, especialmente, em salas refrigeradas, além da humilhação provocada para aumentar a vulnerabilidade do detento e sua vontade em cooperar. Abu Zubaydah, mencionado no item "Relatório da CIA", afirma que passado o momento de sua captura e dos tratamentos para recuperar a saúde, foi transferido para o Afeganistão, onde passou quase dois meses sendo interrogado nu. Após ser examinado por uma mulher, que ele julgou ser médica, e questionado pelo estado de completa nudez, no dia seguinte ele recebeu roupas, entretanto, nesse mesmo dia removeram-nas novamente, sob alegação de que as teriam de volta conforme o nível de cooperação e de informações fornecidas. ${ }^{366}$

Por meio de depoimentos, a Cruz Vermelha concluiu que os médicos responsáveis pelos locais onde os detentos eram mantidos, tinham um papel diretamente relacionado com o monitoramento das sessões de interrogatório, designados pela Cruz Vermelha de maus-tratos, inclusive, em alguns momentos participando de modo mais intenso. Além disso, antes de o presidiário ser transferido e ao chegar ao novo destino, passava por um

\footnotetext{
363 Relatório do Comitê Internacional da Cruz Vermelha. Disponível em: $<$ http://www.nybooks.com/media/doc/2010/04/22/icrc-report.pdf $>$. Acesso em: 21 jan. 2012, p. 3.

${ }^{364}$ Relatório do Comitê Internacional da Cruz Vermelha, op.cit., p. 11.

${ }^{365}$ Relatório do Comitê Internacional da Cruz Vermelha, op.cit., p. 12.

${ }^{366}$ Relatório do Comitê Internacional da Cruz Vermelha, op.cit., p. 14.
} 
exame médico. E, por fim, o detento, após as consequências dos “maus-tratos", era tratado por um médico e recebia cuidados devido ao longo período em cativeiro. ${ }^{367}$

Foi afirmado que os médicos instruíam os interrogadores para continuar, ajustar ou simplesmente encerrar o uso das técnicas reforçadas de interrogatório. De acordo com os detentos os responsáveis pela saúde não se identificavam, mas presumia-se serem médicos ou psicólogos. No caso de afogamento simulado, os médicos participavam diretamente e, quase sempre, faziam uso do oxímetro para verificar a saturação de oxigênio do detento. Em relação às posições estressoras, Bin Attash, algemado com os braços acima da cabeça e os pés tocando o chão, relatou que um médico checava o inchaço de suas pernas com fita métrica e recomendava o momento de interromper a sessão. O detento Hambali, submetido ao mesmo tratamento, relata sobre o exame do inchaço de suas pernas conduzido por um médico que recomendou o término do procedimento e disse: "Eu apenas cuido de seu corpo porque precisamos de você para informações". Uma vítima, que não quis se identificar, afirma a ameaça de um médico sobre o fato de qualquer tratamento estar condicionado a sua cooperação em interrogatório. ${ }^{368}$ Outro detento, chantageado com a infecção do vírus HIV caso não confessasse informações aos interrogadores, teve duas injeções, cujo fluido é até hoje desconhecido, administradas por médicos. Sabe-se, no entanto, que não se tratava do vírus HIV. ${ }^{369}$ Percebe-se com essas ações que a noção de beneficência e não maleficência não estava presente no tratamento desses presos.

Também era dever dos médicos examinar os presidiários antes e depois de cada transferência, o motivo para isso, assim como seus resultados não eram divulgados aos detentos. Sobre os cuidados médicos para ferimentos provocados nos interrogatórios e da vivência no centro de detenção, foi relatado que o tratamento era apropriado e satisfatório. Segundo alguns detentos, eles recebiam tratamento de alto nível. ${ }^{370}$

Em síntese, a Cruz Vermelha conclui que os médicos excederam os limites de seu papel, exploraram as fraquezas dos detentos visando os interrogatórios, monitoraram e auxiliaram esse processo, inclusive, condicionando o tratamento médico à obtenção de informações. Todas as referidas condutas evidenciam o oposto do que propõe a Medicina, ou seja, uma disponibilidade médica para servir ao interrogatório e não ao paciente. Portanto, não há dúvidas de que esses profissionais atuaram em contradição aos padrões

\footnotetext{
${ }^{367}$ Relatório do Comitê Internacional da Cruz Vermelha, op.cit., p. 21.

${ }^{368}$ Relatório do Comitê Internacional da Cruz Vermelha, op.cit., p. 22.

${ }^{369}$ Relatório do Comitê Internacional da Cruz Vermelha, op.cit., p. 32.

${ }^{370}$ Relatório do Comitê Internacional da Cruz Vermelha, op.cit., p. 22.
} 
internacionais de ética médica, podendo ser apurado como participação em tortura e tratamento cruel, desumano e degradante. ${ }^{371}$

Ao término do relatório, a Cruz Vermelha faz uma lista de recomendações ao governo dos Estados Unidos, dentre elas: "que as autoridades dos Estados Unidos investiguem todas as alegações de maus-tratos e tome atitudes para punir os perpetradores e previna que esses abusos ocorram novamente". ${ }^{372}$ Desde 2007, a Cruz Vermelha tem consciência desses abusos do mesmo modo que recomendou aos Estados Unidos a punição dos envolvidos e o completo fim dessas ações. Vale ressaltar, todavia, que, em uma de suas entrevistas, um presidiário confessa aos interrogadores o fato de seus métodos serem estúpidos e contraproducentes e que as informações por ele reveladas eram falsas, elas fizeram os interrogadores desperdiçarem o seu tempo ao emitirem alertas de perigo em locais dos Estados Unidos, tal atitude foi a única maneira que ele encontrou para interromper os atos de violência. ${ }^{373}$ Portanto, em concordância aos comentários que principiaram este capítulo, a tortura não é um método eficaz de obtenção de informações e deveria ser abandonada por completo nos dias de hoje.

\section{h) Arquivos WikiLeaks}

O presente item, discute os memorandos militares dos detentos de Guantánamo, divulgadas no site WikiLeaks, em abril de 2011, com intuito de detectar os abusos cometidos.

Antes faz-se necessário uma análise das informações divulgadas nesse portal. O WikiLeaks é um site de jornalismo investigativo, criado por Julian Assange, em 2007, para publicar informações consideradas sigilosas a fim de trazer transparência em relação aos atos governamentais, é denominado "vazamento com princípios".

O seu funcionamento se dá em cooperação com fontes desconhecidas, normalmente hackers, que enviam o material vazado para o site, o qual não grava as informações das referidas fontes. São aceitos material secreto, censurado ou restrito que apresentem significação política, diplomática ou ética, porém não se aceita rumores ou material publicado anteriormente. Em seguida, a equipe formada por jornalistas atesta a veracidade

\footnotetext{
${ }^{371}$ Relatório do Comitê Internacional da Cruz Vermelha, op.cit., p. 23.

${ }^{372}$ Relatório do Comitê Internacional da Cruz Vermelha, op.cit., p. 27.

${ }^{373}$ Relatório do Comitê Internacional da Cruz Vermelha, op.cit., p. 37.
} 
dos documentos enviados, que ficam "em aguardo" para evitar que a data de vazamento seja estabelecida. Por fim, o material é compilado pela equipe em resumos para ser publicado no site junto dos documentos que o comprovam. ${ }^{374}$

Julian Assange evita viajar aos Estados Unidos por receio de ser preso, pois muitas divulgações comprometem a política externa norte-americana e, especialmente, os abusos cometidos contra a pessoa humana. Em entrevista para a revista Galileu, Assange afirmou que:

O primeiro ingrediente da sociedade civil é direito do povo saber, porque sem essa compreensão nenhum ser humano pode escolher para apoiar significativamente nada. $\mathrm{O}$ conhecimento é o condutor de todo processo político, todas as constituições, todas as leis e todos os regulamentos.

Segundo ele, nenhuma informação recebida pelo site seria preservada para proteger os interesses de alguma nação, "Seria incorreto de nossa parte expressar qualquer favoritismo a alguma nação". "Governos abertos que têm as ações apoiadas pela população não têm o que temer sobre os vazamentos de informações". Outro de seus objetivos é colocar o governo sob escrutínio da população. "Se os governos não querem que a informação seja publicada, eles têm duas opções: não se envolver em guerra que seus próprios militares consideram condenáveis, e não depender do sigilo como um método de governo", explicou. ${ }^{375}$

Dessa forma, é possível imaginar que as informações, mesmo questionáveis, causam alvoroço entre os Estados e, provavelmente, são fidedignas. Com esse pensamento, segue a análise de alguns materiais divulgados no WikiLeaks, em especial, os que possam remeter ao envolvimento médico com tortura em Guantánamo.

Abu Zubaydah, considerado um detento de alto risco, inspirou a criação das "técnicas reforçadas de interrogatório". Conforme explanado anteriormente, ele foi ferido durante sua captura e ficou semanas em recuperação médica, no entanto, ocultou-se o fato de ele ter tido um olho removido cirurgicamente. $\mathrm{Na}$ foto do memorando militar do Departamento de Defesa ele aparece com tapa-olho, em relação a sua saúde consta: "Detento está em boas condições de saúde". 376

\footnotetext{
${ }^{374}$ Site Folha de S.Paulo. Disponível em: < $\underline{\text { http://www1.folha.uol.com.br/mundo/837862-veja-como- }}$ funciona-o-wikileaks.shtml>. Acesso em: 22 jan. 2012.

375 Site revista Galileu. Disponível em: $<$ http://revistagalileu.globo.com/Revista/Common/0,ERT19149517770,00.html >. Acesso em: 22 jan. 2012.

${ }^{376}$ Site WikiLeaks. "The Guantanamo files". Disponível em:

<http://wikileaks.ch/gitmo/prisoner/10016.html>. Acesso em: 22 jan. 2012.
} 
Todas as fichas disponibilizadas no site WikiLeaks comentam do estado de saúde do preso, seu grau de periculosidade, vulgo envolvimento com a Al-Qaeda e as ações realizadas. São fichas de comunicação interna dos militares americanos. Infelizmente, não há fichas médicas à disposição, essas até o momento não "vazaram” para o portal.

De acordo com o jornalista inglês Andy Worthington, que trabalha em cooperação com o site WikiLeaks, a história de Abu Zubaydah a respeito da perda do olho é esquisita. O governo americano alegou que na captura os médicos detectaram uma lesão préexistente em um dos olhos e tentaram salvá-lo em vão. Em contrapartida, o advogado de Zubaydah sustenta a inexistência de uma condição pré-existente nos olhos, afirmando que essa alegação médica é falsa. Em fotos do detento capturado, ele parecia estar com ambos os olhos em perfeitas condições, corroborando a teoria de que em um eventual interrogatório violento houve a lesão que resultou na perda do olho, removido cirurgicamente. As fichas médicas de Zubaydah resolveriam essa dúvida, entretanto, são consideradas "confidenciais" e não estão à disposição para possíveis análises. ${ }^{377}$

Conforme mencionado ao longo deste capítulo, por meio das descobertas de Steven H. Miles e da imprensa, em relação ao caso de Mohammed al-Qhatani, é sabido que a submissão à tortura intensa, provocou a sua morte. No seu memorando militar, análogo ao histórico de Zubaydah, observa-se: "Detento está em boas condições de saúde".378 Novamente, um documento que não confirma nem estabelece vínculo ao tratamento dos médicos, muito menos, se auxiliavam nos interrogatórios.

No memorando de Abu Bakr Ibn Ali Muhammad Al Ahdal há mais detalhes sobre sua saúde: ele estaria em boas condições, apesar de um sopro no coração e do tímpano perfurado no ouvido esquerdo, o qual ele teria recusado tratamento. É considerado detento de alto risco. ${ }^{379}$ Também não representa um achado significativo para este trabalho.

A apreciação dos memorandos constata que na maioria dos casos há somente a menção de "goza de boa saúde" ou, no máximo, anotações sobre condições de saúde psiquiátricas. Por exemplo, consta do memorando de Abd al-Rahim Janko o diagnóstico de

\footnotetext{
${ }^{377}$ Site do jornalista Andy Worthington. Disponível em:

$<$ http:/www.andyworthington.co.uk/2011/05/19/high-value-detainee-abu-zubaydah-blinded-by-the-bushadministration/>. Acesso em: 22 jan. 2012.

${ }^{378}$ Site WikiLeaks. "The Guantanamo files". Disponível em: < http://wikileaks.ch/gitmo/prisoner/63.html>. Acesso em: 22 jan. 2012.

${ }^{379}$ Site WikiLeaks. "The Guantanamo files". Disponível em: < http://wikileaks.ch/gitmo/prisoner/171.html $>$. Acesso em: 22 jan. 2012.
} 
problemas médicos crônicos, além de um histórico psiquiátrico de abuso de substâncias, depressão, transtorno de personalidade "borderline" e tentativa de suicídio. ${ }^{380}$

Enquanto da permanência das fichas médicas como documentos de alto sigilo, não será possível ratificar a veracidade dos abusos cometidos. É de conhecimento público apenas a noção de que os exames eram realizados por médicos, a fim de organizar um histórico da saúde dos detentos. No entanto, o conjunto de documentos revelados, assim como os livros e artigos já publicados, evidenciam que os médicos das Forças Armadas norte-americanas se envolveram com a tortura.

Dos relatos de detentos e do cruzamento de dados com os memorandos, é interessante concluir que o sistema das "técnicas reforçadas de interrogatório" apresenta falhas, pois muitos presidiários, desesperados em razão da dor causada pela tortura, revelaram e delataram falsamente outras pessoas, que acabaram capturadas e interrogadas injusta e inutilmente. Assim, a tortura além de ilegal e manifestamente absurda, é também contraproducente. $^{381}$

\section{i) Relatório de Israel}

Em dezembro de 2011 foi divulgado um relatório israelense a respeito do envolvimento dos médicos na omissão de documentos sobre os abusos cometidos a presos palestinos, além de ignorarem as reclamações de seus pacientes a propósito das lesões advindas de interrogatórios violentos e, dessa forma, permitirem a manutenção das ações por parte dos interrogadores. O texto escrito em outubro de 2011, foi traduzido do hebraico para o inglês em dezembro do mesmo ano, com iniciativa de duas organizações de Direitos Humanos de Israel: "Médicos pelos Direitos Humanos" (Physicians for Human Rights) e "Comitê Público Contra Tortura" (Public Committee Against Torture), engloba o período de detenção de cem palestinos desde $2007 .^{382}$

O introito do relatório em questão apresenta o caso de uma advogada do "Comitê Público Contra Tortura", Meissa Irshaid, que ao ser presa em uma manifestação e

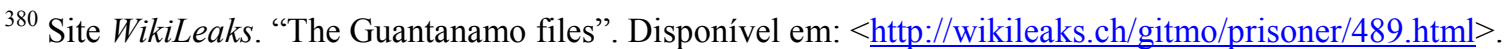
Acesso em: 22 jan. 2012.

${ }^{381}$ Site do jornalista Andy Worthington. Disponível em:

$<$ http://www.andyworthington.co.uk/2011/04/28/study-says-doctors-at-guantanamo-neglected-or-concealedevidence-of-torture-plus-my-interview-with-press-tv/>. Acesso em: 22 jan. 2012.

${ }^{382}$ Site do The Guardian. Disponível em: <http://www.guardian.co.uk/world/2011/nov/03/israeli-doctorsreport-torture-palestinian>. Acesso em: 23 jan. 2012.
} 
estapeada pelas forças policiais, solicitou para ser examinada por um médico. Transferida para o Hospital Ziv, em Zefat, na companhia de pois policiais, ela passou por um exame algemada e relatou ao médico que sua lesão era resultado da violência policial durante a manifestação. O médico respondeu: "Isso não me interessa”. A enfermeira presente complementou: "Se você não gosta daqui, deixe o país e vá para outro lugar". ${ }^{383}$ Essa conduta, em outras palavras, denota como a profissão médica foi direcionada nesse país.

Segundo o relatório, Israel assinou a Convenção Contra Tortura da ONU e aceita a sua proibição como um Direito Costumeiro Internacional, isto é, apesar de não integrar outros tratados sobre o tema já lhe seria obrigatório obedecer a essa interdição. Entretanto, sua Corte Suprema determinou a permissão de meios físicos de interrogatório, desde que signifique o salvamento de vidas. O Código Penal Israelense proíbe os funcionários públicos de fazerem uso da força e ameaças para obter informações de interrogados. Ainda assim, é sabido que essas condutas fazem parte da realidade do país e que nunca houve punição, nesse sentido, a lei está em contradição com as decisões da Corte Suprema de Israel. $^{384}$

Considera-se a ocorrência dos abusos, porque há hierarquias de colaboração para que os perpetradores da Agência de Segurança de Israel (Israeli Security Agency - ISA) permaneçam impunes. A identidade do agente é confidencial e durante o interrogatório é usado um pseudônimo, de modo que a vítima nunca poderia afirmar o responsável. Além disso, as gravações de áudio e vídeo jamais são disponibilizadas para uma investigação, e os documentos que descrevem o interrogatório em si são brandos e não apontam nenhum abuso, justamente para enganar os olhos judiciais. Portanto, em Israel, a sala de interrogatório se torna uma "terra sem lei", privando todas as proteções de um detento. ${ }^{385}$

De acordo com o relatório, as denúncias das vítimas são arquivadas e não resultam em investigações. A lei assegura proteção criminal aos agentes da Agência de Segurança, desde que seus atos tenham sidos em boa-fé e nos limites da razoabilidade. Em razão dessa vaga descrição, os agentes se investem de uma liberdade para alcançarem as informações desejadas. Não suficiente, os médicos colaboram para essa rede de proteção, pois avaliam os detentos antes, durante e após os interrogatórios, normalmente, são as únicas pessoas,

\footnotetext{
${ }^{383}$ The Public Committee against Torture in Israel, Physicians for Human Rights - Israel. Doctoring the Evidence, Abandoning the victim - The involvement of medical professionals in torture and ill treatment in Israel. Periodic Report: October 2011. Disponível em: <http://pt.scribd.com/doc/71825215/Doctoring-theEvidence-Abandoning-the-Victim-The-Involvement-of-Medical-Professionals-in-Torture-and-Ill-Treatmentin-Israel>. Acesso em: 23 jan. 2012, p. 4.

${ }^{384}$ The Public Committee against Torture in Israel, Physicians for Human Rights - Israel, op.cit., p. 10. 385 The Public Committee against Torture in Israel, Physicians for Human Rights - Israel, op.cit., p. 12.
} 
além dos interrogadores, que têm contanto com os presidiários. O que persiste é o silêncio diante das lesões geradas pelos métodos interrogativos. ${ }^{386}$

O dever dos médicos nesses ambientes é o de documentar todos os danos físicos e psicológicos. Na realidade ocorre uma clara violação ao princípio de não maleficência, uma vez que o médico envolvido com esse tipo de crime não cura, não denuncia os abusos e não os documenta para constituir prova posterior. O seu silêncio, muitas vezes, é interpretado como o selo de aprovação para a continuidade da sessão de tortura. Ademais, se o local não apresenta os equipamentos médicos necessários e o detento é levado para um hospital civil, os respectivos profissionais de saúde também ignoram as lesões, não questionam sua origem, apenas tratam e não documentam na ficha médica. Há indícios de que o serviço de segurança pressiona esses médicos para liberarem os detentos (pacientes) rapidamente, evitando internações etc. ${ }^{387}$

Além das noções de ética da Associação Médica Internacional, a estrutura médica israelense se organiza do seguinte modo: Ministério da Saúde, abaixo dele a Ordem dos Médicos, responsável por selecionar os médicos que receberão a licença para atuar como profissionais e a Associação Médica Israelense. A reclamação do relatório consiste no fato de a Associação não estipular diretrizes éticas aos médicos que trabalham em instituições prisionais, gerando incertezas a respeito do bem-estar do detento (paciente) estar em primeiro plano. ${ }^{388} \mathrm{O}$ Protocolo de Istambul e a Declaração de Tóquio são aceitos por Israel e deveriam pautar o tratamento dos presos por parte dos médicos.

O relatório informa que a Associação Médica Israelense falha em seu papel, uma vez que há anos não investiga reclamações de envolvimento médico com tortura, sendo seu dever como entidade fazê-lo e encaminhá-lo à Ordem dos Médicos ou às Cortes criminais para um processo disciplinar. Não suficiente, o código de ética da associação cria limitações à autonomia do médico, deixando-o sem liberdade para atuar probamente, pois em caso de dúvida médica, é levado a uma Corte para decisão. Existe, todavia, uma limitação mais grave, que permite o acesso às fichas médicas por parte dos agentes de segurança e outras autoridades, em circunstâncias excepcionais, violando por completo o respeito ao sigilo médico. Prevalece o bem da sociedade sobre um direito individual do paciente, tudo consiste na supressão da diretriz da Bioética, por meio da qual o bem-estar

\footnotetext{
${ }^{386}$ The Public Committee against Torture in Israel, Physicians for Human Rights - Israel, op.cit., p. 13.

${ }^{387}$ The Public Committee against Torture in Israel, Physicians for Human Rights - Israel, op.cit., p. 14.

${ }^{388}$ The Public Committee against Torture in Israel, Physicians for Human Rights - Israel, op.cit., p. 17.
} 
do paciente é considerado em primeira instância. ${ }^{389}$ Não é missão do médico zelar pela segurança de uma sociedade e fazer uso de seu conhecimento para obter informações às custas do sofrimento de um indivíduo, o qual ele tinha o dever de cuidar. Assim, o cenário israelense, apesar de apoiar os tratados, acordos e convenções contra a tortura, transmite normas ambíguas que auxiliam o surgimento da maleficência médica.

Todos os médicos que trabalham nas prisões de Israel se submetem às ordens do Chefe Médico do Serviço Prisional. Em termos profissionais e éticos respondem ao Ministério da Saúde e ao Serviço Prisional Israelense. Em termos práticos, em detrimento da fiscalização do Ministério da Saúde sobre as condições dos presos, o Serviço Prisional é submetido ao Serviço de Segurança Interna, impedindo o avanço das investigações e conduzindo a ética médica dentro dos presídios conforme seus interesses. ${ }^{390}$ Por sua vez, os hospitais civis também são contaminados por essas influências. Por essas e outras razões, a realidade dos médicos neste país dificulta o seu não envolvimento com a tortura e a sua omissão durante os testemunhos. ${ }^{391}$

O Código Penal Israelense equipara os presos à condição de menores de idade que sofrem maus-tratos (artigo 369D), ou seja, são indefesos e incapazes de obter ajuda em seu ambiente, por isso são chamados de vulneráveis. O médico que não denuncia os maustratos de um menor pode cumprir pena de até seis meses de prisão. Dessa forma, torna-se uma obrigação penal o profissional de saúde documentar e denunciar os casos de tortura e maus-tratos de presidiários, pois eles estabelecem um canal de comunicação que deveria ser isento das influências da força policial ou militar. ${ }^{392}$ Para tanto, é um compromisso do médico prevenir o retorno do detento ao local de interrogatório; oferecer tratamento para o mesmo; examinar e guardar sigilos das informações sobre a saúde do prisioneiro e não explorá-las para tortura; as evidências físicas devem ser documentadas e denunciadas, por fim, deve o médico oferecer suporte físico e emocional ao detento. ${ }^{393}$

O relatório apresenta quatro situações em que os médicos se encontram envolvidos com a tortura nos presídios israelenses. Todos os detentos pediram que seus nomes não fossem divulgados. A primeira situação se refere a não documentação de lesão pelo médico, cuja obrigação é manter uma ficha de cada preso, incluindo seu histórico de saúde, os respectivos tratamentos, diagnósticos etc. Tal documento configura o primeiro item para

\footnotetext{
${ }^{389}$ The Public Committee against Torture in Israel, Physicians for Human Rights - Israel, op.cit., p. 20.

${ }^{390}$ The Public Committee against Torture in Israel, Physicians for Human Rights - Israel, op.cit., p. 23.

391 The Public Committee against Torture in Israel, Physicians for Human Rights - Israel, op.cit., p. 24.

392 The Public Committee against Torture in Israel, Physicians for Human Rights - Israel, op.cit., p. 26.

${ }^{393}$ The Public Committee against Torture in Israel, Physicians for Human Rights - Israel, op.cit., p. 28.
} 
investigação de um caso de tortura, entretanto, a realidade não está descrita nas páginas dessas fichas. A organização "Comitê Público Contra Tortura" sugere a fotografia e uma precisa descrição das lesões além do relato completo do paciente, do seu diagnóstico e do tratamento dispensado. ${ }^{394}$

No caso de "M.A.", um jovem de 22 anos, preso em 11 de junho de 2008, sua declaração juramentada ("affidavit”, em que o indivíduo jura falar a verdade, típico de "Common Law") atesta que as algemas de plástico que o seguraram após a captura estavam tão apertadas que deixaram marcas duradouras, por cerca de uma semana. Ele foi forçado a ficar em posições estressoras por horas, de joelhos e se apoiando nas pontas dos pés, foi espancado e jogado contra um banco pelos soldados, o que lhe causou uma lesão no olho, após um mês, ainda sentia dificuldade para ler. No dia 12 de junho, M.A. foi examinado por um médico, em sua ficha médica, no espaço para "Reclamações do preso durante o exame", constava: "sem sensibilidades a medicamentos e sem medicamentos de uso regular. Esteve envolvido em um acidente de carro há dois meses, mas não se machucou e pouco tempo após se sentia bem.". No trecho de "Comentários do médico" estava descrito: "Condição física geral satisfatória, batimentos cardíacos regulares”, seguia uma frase completamente ilegível e no final: "Não precisa de tratamento". M.A. esteve nessa clínica ao longo de duas semanas e ainda não havia registro da lesão, somente no dia 26 de junho consta: "reclama de dor nos dentes e nos olhos". Não se sabe ao certo se M.A. explicou aos diferentes médicos que o trataram sobre a origem dos ferimentos. Entretanto, da leitura de sua declaração juramentada apreende-se que as lesões conformavam provas evidentes, de modo que os médicos deveriam ter fotografado, documentado e denunciado mesmo sem a aquiescência do presidiário. Em 30 de junho de 2008, M.A. esteve perante um juiz, nessa ocasião reclamou de seu olho e de ter sido espancado, este decretou que ele fosse levado a um oftalmologista, ou seja, mesmo um leigo, semanas após o ocorrido, percebeu a agressão física. O caso foi levado à discussão para punir os envolvidos, mas até o presente momento não se obteve respostas do Procurador-geral militar. ${ }^{395}$

Segundo o relatório, não raro as fichas médicas são "perdidas" ou estão completamente ilegíveis. Há alguns anos adotou-se o sistema computadorizado, mesmo assim o Comitê Contra Tortura não recebe a íntegra das fichas e quando isso ocorre se dá com meses e até anos de atraso em relação ao pedido de investigação. Quase nunca

\footnotetext{
394 The Public Committee against Torture in Israel, Physicians for Human Rights - Israel, op.cit., p. 29.

395 The Public Committee against Torture in Israel, Physicians for Human Rights - Israel, op.cit., p. 30.
} 
apresentam informações claras e fidedignas, ratificando que o dever médico de documentar a realidade de seus pacientes em detenção não é cumprido. ${ }^{396}$

O silêncio dos profissionais de saúde em relação à denúncia dos abusos cometidos aos presidiários considerados vulneráveis se desdobra alcançando o ponto de consentir com a tortura.

O detento "T.S.", por exemplo, espancado e mordido por um cachorro dos soldados, foi tratado por um médico em um hospital. Apesar de sua ficha médica se encontrar perfeitamente detalhada, inclusive, no que diz respeito ao tratamento concedido, nenhum órgão externo foi avisado sobre o ocorrido. A documentação existe, mas o fato foi silenciado. ${ }^{397}$

Em outro caso, “T.C.”, nascido em 1983, foi submetido a um interrogatório que incluiu espancamento, isolamento, privação de sono, uso de algemas em posições estressoras etc., além de ferimentos por todo o corpo, ele apresentava uma lesão no olho. Enquanto um dos médicos que o examinou pediu sua simples cooperação, outro chegou a documentar e, inclusive, enviar uma cópia da ficha médica para a polícia, tão pronto arquivada. Perante todo um sistema "envenenado", o ato de bravura de um profissional nunca conformará uma panaceia, falta uma infraestrutura de suporte para os médicos que ainda acreditam no valor da beneficência e não maleficência. ${ }^{398}$

Não oferecer o "Refoulement" figura outra fuga médica em relação ao seu dever ético. Termo do Direito Internacional, que consta da Convenção de Refugiados de 1951 e também da Convenção Contra Tortura, trata-se de uma proteção aos refugiados, ou vítimas em geral, para que não retornem nem sejam enviados de volta ao local onde sua vida corre risco. Nesse sentido, o médico que examina o detento com claros sinais de abusos por parte dos interrogadores tem o dever de não encaminhá-lo para eles. A constatação de um paciente repleto de lesões e seu consequente reenvio para a manutenção dos atos de tortura denota aprovação do procedimento por parte do médico. ${ }^{399}$

No caso de "S.A.", preso em 22 de abril de 2011 e submetido a um interrogatório com algemas apertadas, restrição de comida, abusos verbais, além da privação de acesso ao banheiro. Por questões digestivas, conduziram-no a um médico, que lhe deu um medicamento e o transferiu novamente à sala de interrogatório. Após um tempo, conduzido

\footnotetext{
396 The Public Committee against Torture in Israel, Physicians for Human Rights - Israel, op.cit., p. 33.

${ }^{397}$ The Public Committee against Torture in Israel, Physicians for Human Rights - Israel, op.cit., p. 34.

${ }^{398}$ The Public Committee against Torture in Israel, Physicians for Human Rights - Israel, op.cit., p. 36.

${ }^{399}$ The Public Committee against Torture in Israel, Physicians for Human Rights - Israel, op.cit., p. 36.
} 
de volta a sua cela, ele começou a vomitar sangue. Um dos guardas o empurrou para dentro da clínica médica do presídio, o profissional de saúde responsável administrou duas injeções e uma pílula, mantendo-o em observação por meia hora. Logo, retornou a sua cela e, no dia seguinte, voltou a ser interrogado. Na ficha médica consta que S.A. esteve muitas vezes na clínica e que apresentava leves marcas vermelhas nos pulsos devido ao uso razoável de força pelos interrogadores. Como um médico é capaz de constatar a intensidade da força? Ao tomar consciência da condição física da vítima, como é capaz permitir o prosseguimento do interrogatório? Levado para investigação pelo órgão interno do presídio, o caso foi arquivado. Sabe-se que houve apelação, da qual, todavia, não há respostas. $^{400}$

A presença de médicos tanto em centros de detenção quanto em interrogatório não protege seus pacientes, longe disso, configuram um selo de aprovação para que a tortura e os maus-tratos ocorram, pois o médico é responsável por declarar a capacidade do indivíduo em suportar mais abusos. A situação se torna ainda pior a partir do momento em que as fichas médicas ficam à disposição dos interrogadores, conforme mencionado anteriormente. Dessa forma, as fraquezas físicas e psicológicas são exploradas para sofisticar a técnica de coerção. ${ }^{401}$ No caso de "M.J.", de 47 anos, sua declaração juramentada revela que, além de sofrer violência, teve a mão envolta por algemas apertadas, privação de sono e recebeu ameaças sobre sua família. Os médicos que realizaram o seu exame, misteriosamente, anotaram as condições de saúde na antiga ficha escrita, em vez de usarem o sistema computadorizado, na verdade é uma atitude arquitetada, pois desse modo as informações são encaminhadas aos interrogadores. Uma vez mais, a respectiva denúncia encontra-se arquivada. A organização Médicos pelos Direitos Humanos enviou oito casos para o Ministério da Saúde denunciando violação do sigilo da ficha médica e solicitando a revogação da licença profissional dos envolvidos. Segundo a resposta os médicos seriam advertidos sobre isso e nada mais. ${ }^{402}$

Além das condutas citadas, ainda houve cooperação médica com os interrogadores, evidenciando uma participação direta nos abusos. "S. Tz.”, preso em 17 de março de 2008, foi espancado pelos soldados, durante as ações sofreu um corte de faca e caiu inconsciente no chão. Um médico chamado Shalit o chutou e inseriu uma bolsa de infusão em sua boca, em seguida, aplicou injeções em sua perna, provocando inchaço. O profissional

\footnotetext{
400 The Public Committee against Torture in Israel, Physicians for Human Rights - Israel, op.cit., p. 38.

401 The Public Committee against Torture in Israel, Physicians for Human Rights - Israel, op.cit., p. 39.

402 The Public Committee against Torture in Israel, Physicians for Human Rights - Israel, op.cit., p. 40.
} 
supostamente diagnosticou sérios problemas nos rins de S.Tz., e solicitou um tratamento, que seria oferecido apenas com a promessa de cooperar no interrogatório. O caso foi denunciado e continua sem respostas. ${ }^{403}$

Por fim, segundo discussões anteriores, os médicos de hospitais civis também não amparam os detentos vítimas de interrogatórios torturantes. Sempre fazem "vista grossa" e há indícios de que a própria estrutura dos hospitais é organizada de modo a integrar todo um sistema de dissimulação dessas condutas, preparando os médicos para ignorarem qualquer indício. ${ }^{404}$

A parte final do relatório lista algumas recomendações para que esses atos hediondos não se repitam no universo médico, a saber: que regras claras sejam escritas sobre o tratamento médico de presos conforme o Protocolo de Istambul; que o Ministério da Saúde e o corpo médico do Serviço Prisional de Israel organizem um mecanismo de investigação dos médicos que violam as regras; que as associações médicas ofereçam proteção aos médicos que anseiam o bem-estar dos seus pacientes e se opõem às pressões dos membros da Agência de Segurança; que os médicos envolvidos tenham suas licenças profissionais cassadas; afastar os médicos da jurisdição dos da prisão e segurança interna devolvendo-lhes a autonomia; que um órgão imparcial investigue as denúncias; que os envolvidos com tortura sejam levados a julgamento; que o Estado, presídios e hospitais tenham a obrigação de preservar as evidências, especialmente as fichas médicas, para ajudar as vítimas de tortura a comprovar suas alegações, por fim, que todo médico não aceite empregos em locais com suspeitas de figurar um centro de interrogatórios. ${ }^{405}$ Importante ressaltar que, assim como os Estados Unidos, Israel não ratificou o Estatuto de Roma e, portanto, não se submete à jurisdição do Tribunal Penal Internacional.

\section{j) Medida de segurança e formas atuais de participação do médico no sofrimento alheio}

Neste tópico pretende-se observar outros modos pelos quais os médicos estariam compactuando com a noção de tortura, não para obter uma informação em nome de uma autoridade governamental, mas no sentido de causar sofrimento intencional a um paciente.

\footnotetext{
${ }^{403}$ The Public Committee against Torture in Israel, Physicians for Human Rights - Israel, op.cit., p. 41.

404 The Public Committee against Torture in Israel, Physicians for Human Rights - Israel, op.cit., p. 45.

${ }^{405}$ The Public Committee against Torture in Israel, Physicians for Human Rights - Israel, op cit., p. 55.
} 
Primeiro, analisa-se o laudo de periculosidade emitido por um médico no caso da medida de segurança.

As medidas de segurança no Direito Penal Brasileiro constituem, ao lado das penas, uma espécie de sanção aplicada pelo Estado ao agente inimputável ou semi-imputável, quando do cometimento de um fato ilícito e típico. Acrescido a esse aspecto objetivo e material, o cometimento de ação típica e ilícita, figura um critério de ordem subjetiva: a periculosidade do agente. Assim, para a aplicação da medida de segurança concorrem a prática de ato típico e ilícito e a constatação de probabilidade de reiteração, por este mesmo agente, isto é, por meio da reincidência. De acordo com o professor Eduardo Reale Ferrari,

[...] a medida de segurança constitui uma providência do poder político que impede que determinada pessoa, ao cometer um ilícito-típico e se revelar perigosa, venha a reiterar na infração, necessitando de tratamento adequado para sua reintegração social. ${ }^{406}$

Em outras palavras, aquele que comete um crime e é considerado inimputável ou semi-imputável não cumprirá pena privativa de liberdade em cárcere, mas receberá tratamento em hospital de custódia e tratamento psiquiátrico ou sujeição a tratamento ambulatorial.

Para aferição da pessoa considerada inimputável ou semi-imputável, um médico examina as condições mentais e psicológicas do infrator, de modo a analisar se ao tempo do crime o agente apresentava pleno ou parcial discernimento de seu comportamento. No caso do inimputável, a periculosidade é presumida, pois apresenta um estado subjetivo e moderadamente duradouro de antissociabilidade que pode levar o agente a delinquir uma vez mais, o indivíduo é tido como perigoso. Por sua vez, para o semi-imputável, a periculosidade deve ser comprovada em uma circunstância concreta. ${ }^{407}$

O médico apresenta dois papéis importantes, o de analisar se o indivíduo é inimputável e semi-imputável ao longo do processo. Quando imposta, a medida de segurança não apresenta um prazo determinado para encerrar, ela é condicionada a um exame anual no infrator com intuito de verificar se a periculosidade permanece. Dessa forma, o indivíduo fíca à mercê do parecer da perícia médica, acorrentado ao seu tratamento terapêutico por tempo indeterminado.

\footnotetext{
${ }^{406}$ FERRARI, E.R., Medidas de Segurança e Direito Penal no Estado Democrático de Direito, São Paulo, Revista dos Tribunais, 2001, p. 15.

${ }^{407}$ MASSON, C., Direito Penal Parte Geral, v. 1, $3^{\text {a }}$ ed., São Paulo, Método, 2010, p. 790.
} 
Poderia o profissional de saúde contribuir intencionalmente para a permanência de um indivíduo além do tempo necessário nessas instituições? Seguramente é uma questão para se pensar, afinal, a própria noção de periculosidade é subjetiva, pois visa investigar a propensão de alguém para o mal, caracterizado, especialmente, pela permanente prática de crimes. É possível pensar essa ideia como metáfora da noção de tortura, no sentido específico de infligir tratamento em local torturante por mais tempo que o permitido, pelo simples fato de eliminar um elemento teoricamente perigoso do convívio social. As instituições onde os infratores são tratados, notoriamente conhecidas como manicômios judiciários, possuem péssima reputação, tanto pela falta de transparência em relação aos métodos dispensados para o tratamento quanto pelos relatos de que são locais onde não se consegue a recuperação da pessoa.

Nesse sentido, o promotor de Justiça, Haroldo Caetano da Silva, escreve um interessante artigo sobre outras possibilidades. Desde 2001 surgiu a Lei $n^{\circ} 10.216 / 2001$, a Lei da Reforma Psiquiátrica ou Lei Antimanicomial, que humaniza o atendimento à saúde mental, transferindo o foco do tratamento para serviços comunitários e abertos, também alcança a internação compulsória, determinada pela justiça criminal como medida de segurança. $^{408}$

Assim, havendo essa possibilidade deve o juiz preferir o tratamento ambulatorial e optar pela internação somente "quando os recursos extra-hospitalares se mostrarem insuficientes", conjuntura precedida de "laudo médico circunstanciado que caracterize os seus motivos". A periculosidade perde, então, sua força. A medida de segurança não tem natureza retributiva, ela é entendida como curativa. A permanência indeterminada do paciente em cadeia pública ou em manicômio judiciário configura crime de tortura (Lei $\mathrm{n}^{\mathrm{o}}$ 9.455/97). Portanto, o médico psiquiatra que estabelece, por meio de um critério plenamente subjetivo, a permanência do indivíduo nesses centros compactua com o crime de tortura, conforme art. $1^{\mathrm{o}}, \S 1^{\mathrm{o}}$ da Lei de tortura.

Outra sugestão oriunda do Programa de Atenção Integral ao Louco Infrator PAILI, contempla a execução das medidas de segurança de acordo com a Lei no 10.216, acolhendo os seus pacientes nos serviços de saúde. Com autonomia, as equipes de saúde colocam em prática a melhor terapêutica, sem a necessidade de prévia deliberação judicial.

\footnotetext{
${ }^{408}$ SILVA, H.C., "Reforma psiquiátrica nas medidas de segurança: a experiência goiana do PAILI", Rev. bras. crescimento desenvolv. hum., v. 20 n. 1, São Paulo, abr. 2010. Disponível em: $<$ http://pepsic.bvsalud.org/scielo.php?pid=S0104-12822010000100015\&script=sci_arttext $>$. Acesso em: 24 jan. 2012.
} 
O programa encaminha a pessoa submetida à medida de segurança para o ambiente universal do Sistema Único de Saúde, o que favorece sobremaneira a inclusão da família e da sociedade, funcionando como experiência de sucesso no resgate da dignidade desses pacientes, além de evidenciar a transparência do tratamento.

O médico responsável pelo laudo que indica a existência ou não da periculosidade deve refletir sobre essas novas possibilidades. Não suficiente, deve reconhecer que a permanência fracamente justificada de um indivíduo em determinada instituição de tratamento pode ser considerada tortura.

De tal sorte, é relevante pensar outras situações em que o médico pode se aproximar de uma conduta torturante. Muitas vezes, para que um tratamento tenha sucesso, o paciente se submete a procedimentos dolorosos em locais desagradáveis, por exemplo, a Unidade de Tratamento Intensivo (UTI). Inclusive, a internação em hospital por si mesma configura uma espécie de desconforto ao corpo humano. O médico sensível aos sentimentos do paciente sabe o quanto ele é capaz de suportar, além disso, não desconsidera a saúde mental como condição essencial à manutenção da vitalidade humana. Entretanto, existem situações em que a preservação da vida se esbarra com o próprio conceito de autonomia do paciente, nesse sentido, prossegue-se com o tratamento apenas para que a vida continue, independente do sofrimento. A distanásia consiste no prolongamento da vida por meio de tratamentos fúteis, desnecessários, normalmente prolongando a dor e o sofrimento do paciente.

Não raro, os pacientes terminais passam a recusar o tratamento de sua doença, desejando apenas paliativos que mantenham sua qualidade de vida durante o curto período que lhes resta. Porém, há médicos de tradição patriarcal, que se julgam sabedores por excelência das necessidade do paciente, e continuam um tratamento com intuito de prolongar a vida, apenas para que a pessoa permaneça "viva". É um claro desrespeito à autonomia do paciente, segundo o capítulo de Bioética, quando dois valores como beneficência e autonomia se entrecruzam, é essencial observar se a beneficência continua trazendo benefícios diretos ao paciente, e não para sua família, sociedade ou outros pacientes, nesse caso, a autonomia se torna mais valiosa e deve prevalecer sobre a beneficência.

Entende-se por distanásia, o prolongamento da vida de um paciente sem chance de cura ou sem representar um cuidado paliativo, equiparando-se também a uma prática de tortura, pois mantém o paciente prisioneiro de seu próprio corpo. Essa circunstância se 
torna ainda mais grave quando se trata de pacientes em estado vegetativo. A família poderia responder em nome do parente, mas a noção de sofrimento é um tanto subjetiva, por essa razão o ideal seria ponderar, ao longo da vida do paciente, quais manifestações de vontade foram expressas e tentar se decidir por meio delas. A Associação Médica Mundial recomenda que em alguns casos é interessante o uso dos "living wills"409, isto é, os testamentos vitais, no qual o paciente estabelece a priori as aspirações relacionadas a um momento em que sua capacidade racional esteja comprometida, por exemplo, um coma.

Para a professora Maria Júlia Kóvacs, coordenadora do Laboratório de Estudos sobre a Morte do Instituto de Psicologia da Universidade de São Paulo, em seu artigo intitulado "Bioética nas questões de vida ou morte", entende-se que:

A morte no século XXI é vista como tabu, interdita, vergonhosa; por outro lado, o grande desenvolvimento da Medicina permitiu a cura de várias doenças e um prolongamento da vida. Entretanto, este desenvolvimento pode levar a um impasse quando se trata de buscar a cura e salvar uma vida, com todo o empenho possível, num contexto de missão impossível: manter uma vida na qual a morte já está presente. Esta atitude de tentar preservar a vida a todo custo é responsável por um dos maiores temores do ser humano na atualidade, que é o de ter a sua vida mantida à custa de muito sofrimento, solitário numa UTI, ou quarto de hospital, tendo por companhia apenas tubos e máquinas. ${ }^{410}$

Nesse sentido, em tempos atuais a maioria dos médicos demonstra uma sensação de poder se combater a morte, que normalmente é associada ao fracasso. Muitos profissionais de saúde exteriorizam a seguinte frase "Espero que não ocorra durante meu plantão". A tecnologia permite prolongar a vida, mesmo que consista apenas em uma "sobrevivência". Os indivíduos submetidos ao tratamento em unidades intensivas (UTI) revelam que sentiram fome, sede e sono durante esses cuidados. Seria o prolongamento da vida uma vontade do paciente, do médico para evitar responder por um processo ou uma vontade da sociedade contemporânea em ampliar a vida o máximo possível? De qualquer modo, o prolongamento da vida sem benefícios ao paciente é um ato cruel tal qual os maus-tratos de uma tortura.

No Brasil é terminantemente proibida a prática da eutanásia, no entanto, a ortotanásia foi permitida após a Justiça Federal ter revogado a liminar que suspendia a sua

\footnotetext{
${ }^{409}$ STOLZ, C.; GEHLEN, G.; BONAMIGO, E.L.; BORTOLUZZI, M. C., "Manifestação das vontades antecipadas do paciente como fator inibidor da distanásia", Revista Bioética, CFM, v. 19, n. 3, 2011, p. 834. Disponível em: $<$ http://revistabioetica.cfm.org.br/index.php/revista_bioetica/issue/view/40>. Acesso em: 25 jan. 2012.

${ }^{410}$ KOVACS, M.J., Bioética nas questões de vida e morte, Universidade de São Paulo, 2002. Disponível em: $<$ http://www.ufpel.tche.br/medicina/bioetica/bioeticaquestoesvidamorte.pdf $>$. Acesso em: 25 jan. 2012.
} 
regulamentação no país. ${ }^{411}$ A eutanásia pura e simples consiste em uma ação que leva à morte, se referida ação for efetuada, por exemplo, pela administração de uma injeção letal, considera-se eutanásia ativa. Por sua vez, a ausência de um ato caracteriza a eutanásia passiva, como desligar os aparelhos que permitem uma paciente respirar, ou encerrar sua alimentação.

Por outro lado, a ortotanásia configura o processo natural da morte, não há obrigatoriedade de salvação da vida a qualquer custo. Assim pode ser proposto ao paciente ou ele mesmo toma a decisão para que sejam eliminados os processos de salvação, ministrando somente os cuidados paliativos para atenuar a dor, em outras palavras, permite que a morte transcorra a seu livre curso, ela não é provocada.

Portanto, o médico que afirma temer um processo por encerrar os tratamentos de sustentação da vida, mas mantém os cuidados paliativos para suavizar a dor até a chegada da morte ingressa no universo da ortotanásia, prática permitida pela legislação atual brasileira.

O Novo Código de Ética Médica, CFM 1931/09, em seus Princípios Fundamentais, inciso XXII, possui duas claras vedações à distanásia: "Nas situações clínicas irreversíveis e terminais, o médico evitará a realização de procedimentos diagnósticos e terapêuticos desnecessários e propiciará aos pacientes sob sua atenção todos os cuidados paliativos apropriados.". Também no art. 41, parágrafo único: "Nos casos de doença incurável e terminal, deve o médico oferecer todos os cuidados paliativos disponíveis sem empreender ações diagnósticas ou terapêuticas inúteis ou obstinadas, levando sempre em consideração a vontade expressa do paciente ou, na sua impossibilidade, a de seu representante legal". 412

O médico que mantiver a vida de um paciente com tratamentos fúteis, que além de não proporcionar bem-estar, exclui sua dignidade e prolonga de modo exagerado o processo de morte, afastando o direito de terminar a vida em paz estará violando as normas do Código de Ética e poderá responder por processo disciplinar. A distanásia se relaciona à noção de maleficência quando inflada pela arrogância de preservar uma vida ativa em

\footnotetext{
${ }^{411}$ Site de notícias IG. Disponível em: $<$ http://ultimosegundo.ig.com.br/brasil/justica+suspende+liminar+e+libera+pratica+de+ortotanasia/n1237851 033103.html >. Acesso em: 13 dez. 2011.

${ }^{412}$ STOLZ, C.; GEHLEN, G.; BONAMIGO, E.L.; BORTOLUZZI, M. C., op.cit., p. 835.
} 
razão da tecnologia moderna, pensando exclusivamente na doença como um desafio científico e desconsiderando a pessoa humana em toda sua completude. ${ }^{413}$

Nesse sentido, os médicos da atualidade devem elucubrar sobre seu papel em determinadas circunstâncias em que sua respectiva ação ou omissão configurariam práticas geradoras de sofrimento e, portanto, aptas a serem consideradas práticas de tortura. Se esses profissionais se pautassem em cada caso pelo equilíbrio dos princípios da autonomia, beneficência e não maleficência, os confrontos morais seriam resolvidos com menores danos ao paciente e à própria carreira do médico.

${ }^{413}$ FEIO, A.G.O.; OLIVEIRA, C.C., "Responsabilidade e tecnologia: a questão da distanásia”, Revista Bioética, CFM, v. 19, n. 3, 2011, p. 618. Disponível em: 


\section{VI - CONCLUSÃO: POSSÍVEIS SOLUÇÕES}

Este capítulo pretende desenvolver possíveis soluções a questão relacionada ao envolvimento médico com tortura e a consequente transgressão de seus preceitos éticos. Nessa conjuntura, a responsabilidade é do Estado, das associações médicas ou, por se tratar de um crime contra a humanidade, deveria ser competência do Tribunal Penal Internacional?

Pretende-se também coibir as práticas abusivas dos médicos, por meio do desenvolvimento do papel que cumpre certas organizações internacionais, e auxiliar o médico coagido que não aceita participar de tortura, mas teme por sua segurança e de sua família.

\section{a) Sanções aos médicos, influência de organizações internacionais e amparo aos futuros médicos}

Segundo estudos do Capítulo IV, a maioria dos médicos envolvidos na Segunda Guerra Mundial sofreu punições pelos Tribunais de Exceção estabelecidos. Após esse período histórico, no entanto, como explanado nas discussões do Capítulo $\mathrm{V}$, poucos profissionais de saúde foram punidos. É sabido que durante a guerra contra o terror houve a participação ativa dos médicos nas técnicas reforçadas de interrogatório e, recentemente, em Israel, são desenvolvidas as mesmas práticas. A impunidade vai permanecer? Há no mundo instituições suficientes para controlar e impedir esses atos? O médico responsável por examinar e documentar a tortura cumpre seu papel?

O Dr. Steven H. Miles se uniu a outras duas pesquisadoras, Telma Alencar e Brittney N. Crock, com intuito de elaborar um artigo para a organização internacional "Conselho de Reabilitação Internacional para Vítimas de Tortura" (IRCTV - International Rehabilitation Council for Torture Victims) sobre a experiência de punição dos médicos envolvidos com tortura e crimes contra a humanidade desde a Segunda Guerra Mundial. Os resultados ilustram que a sociedade civil configura o cerne para encerrar de uma vez 
por todas a impunidade, para tal, a assistência de um organismo oficial de punição, apesar de sua improvável constituição, seria de absoluta importância. ${ }^{414}$

O método empregado se fundamenta na organização de informações disponíveis sobre médicos que teriam sido investigados e punidos perante Cortes internacionais, Cortes criminais nacionais, Tribunais militares e associações médicas, dentre as quais, os Conselhos de Medicina e as sociedades médicas. Os casos em estudo poderiam estar em andamento ou julgados de antemão, no qual o profissional, considerado culpável, foi liberado por meio de uma lei de anistia. Trabalhou-se com buscas em sites de Direito, da Corte Europeia de Direitos Humanos, da Universidade do Minnesota e de grupos de Direitos Humanos. De acordo com uma pesquisa qualitativa, a cada médico interrogado e punido, obtinha-se menção de outros profissionais que, por sua vez e em troca de anistia ou perdão, delatavam mais casos de envolvimento. Todavia, muitas informações se perderam. $^{415}$

Em 1975, a Grécia foi o primeiro país a punir um médico por tortura após a Segunda Guerra Mundial. Segundo pesquisa, que compõe o artigo citado, até meados de 2009, 56 médicos de oito diferentes países foram punidos por tortura ou crimes contra a humanidade. Desses, 46 (82\%) foram julgados por Conselhos de Medicina e sociedades médicas em quatro países, $10(22 \%)$ foram condenados e encarcerados por Cortes nacionais de quatro países e Cortes internacionais aprisionaram 2 (4\%) médicos da antiga Iugoslávia, ainda há 18 processos em aberto. Em alguns casos, o médico sofreu pena de um Conselho de Medicina e agora responde por processo criminal. Apesar de os Conselhos de Medicina e as Cortes criminais punirem os atos de tortura, assassinato, sequestro e falsificação de atestado de óbitos, cada instituição desempenha um papel diferente. Os primeiros punem do ponto de vista da ética médica, cassando as licenças profissionais e aplicando penas de censura pública ou privada, revogação de títulos, expulsão da associação etc. Por sua vez, as Cortes impõem pena de detenção, inclusive, perpétua. Não há pena de morte, entretanto, no Chile, um médico militar que teve sua licença cassada foi assassinado tão logo da decisão judicial. No Brasil, um juiz determinou que o médico militar pagasse uma pensão à família da vítima de tortura como reparação. No caso de

\footnotetext{
${ }^{414}$ MILES, S.H.; ALENCAR, T.; CROCK, B.N., "Punishing physicians who torture: A work in progress", Journal on Rehabilitation of Torture Victims and Prevention of Torture, v. 20, n. 1, 2010, p. 23. Disponível em: <http://www.irct.org/library/torture-journal/back-issues/volume-20--no.-1--2010.aspx>. Acesso em: 25 jan. 2012.

${ }^{415}$ MILES, S.H.; ALENCAR, T.; CROCK, B.N., op.cit., p. 24.
} 
crimes que provocaram atrocidades em massa, uma Corte internacional assume a incumbência. Dois médicos da antiga Iugoslávia e três de Ruanda foram presos. ${ }^{416}$

A sociedade civil latino-americana, por meio de grupos defensores dos Direitos Humanos, deu origem a um distinto e curioso modo de punição. Nos julgamentos de médicos envolvidos com tortura em que há falha por parte da Justiça, esses grupos expõem à vergonha o indivíduo, por exemplo, criam-se websites com fotos dos supostos torturadores, todo seu histórico militar, o nome das vítimas, além do endereço e telefone do profissional. Outros grupos organizam manifestações em frente à casa desses médicos.

Mediante pesquisas, quando convocados para depor, alguns médicos negavam completamente a participação em atrocidades enquanto outros alegavam patriotismo e obediência militar ou diziam temer a tortura, atitude comum na América Latina, onde alguns médicos torturavam seus próprios colegas e, inclusive, estudantes de Medicina. O psiquiatra brasileiro Amílcar Lobo, mencionado no capítulo anterior, admitiu a tortura de quinhentos prisioneiros, em sua defesa, relatou:

[...] o homem tem usado tortura e assassinato por milhares de anos e é permitido desde que socialmente organizado. É parecido com as torturas da Inquisição, o assassinato dos judeus e as ações do regime nazista. Faz parte da natureza humana e eu não tenho vergonha de fazer parte disso. ${ }^{417}$

$\mathrm{Na}$ África do Sul, conforme o relatório de Israel, o incidente que chamou a atenção durante o "Apartheid", regime de segregação racial que durou de 1946 a 1994, foi a morte de Steve Biko, em 1977, envolvendo os médicos Tucker e Lang.

Espancado pela polícia e transferido para um hospital a mais de mil quilômetros de distância, Biko não sobreviveu à viagem. O Conselho Médico sul-africano acusou os médicos de não cumprirem sua missão, desse modo Tucker, médico sênior, teve sua licença suspensa por três meses, a sentença de Lang, médico júnior, recebeu pena de censura.

A Dra. Wendy Orr, jovem médica que trabalhava para o governo sul-africano, figura uma atitude de coragem. Ao perceber que dispensava cuidados a detentos submetidos à tortura policial, ela não se calou e delatou os respectivos maus-tratos, por outro lado, cientes do que ocorriam, outros profissionais que trabalhavam junto dela, ignoraram os fatos. A Dra. Orr apelou para a Suprema Corte exigindo o fim dos abusos

\footnotetext{
${ }^{416}$ MILES, S.H.; ALENCAR, T.; CROCK, B.N., op.cit., p. 25.
}

${ }^{417}$ MILES, S.H.; ALENCAR, T.; CROCK, B.N., op.cit., p. 27. 
policiais e obteve a concessão de seu pedido. Em 1996, indicada pelo presidente Nelson Mandela para a Comissão de Verdade e Reconciliação, se tornou um ícone e possibilitou a discussão de outros casos em que médicos lutaram contra ameaças e coerções para manter suas condutas éticas. Com o fim do regime Apartheid, essa mesma Comissão concedeu anistia aos médicos que confessaram a participação em crimes de tortura. ${ }^{418}$ A África do Sul, então, se mostra como uma nação capaz de perdoar os erros do passado, desde que uma lição seja aprendida e constitua exemplo aos futuros médicos.

Por todos os aspectos analisados, o artigo de Miles evidencia um progresso em institucionalizar os mecanismos de punição dos médicos torturadores. $\mathrm{O}$ desenvolvimento nos diferentes países se dá em etapas, por exemplo, na Líbia e Coreia do Norte, qualquer discussão sobre um médico envolvido com tortura é suprimida, havendo total negação do fato, essa seria a primeira etapa. A segunda consiste em nações, como o Egito, os Estados Unidos, o Reino Unido, as Filipinas e a Venezuela, condenarem médicos que ocultam a tortura, mas não punem médicos do governo que colaboraram com essa prática. Na terceira etapa, Grécia e África do Sul focaram-se em um indivíduo ou incidente simbólico. Finalmente, a quarta etapa, representada por Argentina, Brasil, Chile e Uruguai, criaram sistemas para regularizar a punição de médicos que auxiliaram a tortura e crimes contra a humanidade. ${ }^{419}$

As diferenças em relação aos mecanismos de punição ilustram as tentativas, pensadas em um panorama universal, em extinguir a tortura. Há governos que por meio da dissimulação das Forças Armadas e da simpatia que elas alcançam em algumas Cortes, protegem seus médicos torturadores, outros concedem anistia geral e, há casos, nos quais mesmo da perda de sua licença profissional, o médico é convocado e aceito para atuar no Exército. Em todas as circunstâncias reina a impunidade. Dessa forma, as instituições mais producentes surgem da sociedade civil, pois são capazes de pressionar, reunir evidências das atrocidades cometidas e mobilizar a opinião pública para punir os responsáveis. Alguns desses ativistas, incluindo médicos, quase sempre, são ameaçados, processados por difamação, forçados a se exilar, presos, torturados e até mortos. Atualmente a maior dificuldade é a obtenção de evidências: as prisões são secretas, os relatórios governamentais destruídos e as táticas de tortura minimizam cicatrizes e marcas. Além disso, os sobreviventes relatam a impossibilidade de identificação, devido ao uso de

\footnotetext{
${ }^{418}$ The Public Committee against Torture in Israel, Physicians for Human Rights - Israel, op.cit., p. 49.

${ }^{419}$ MILES, S.H.; ALENCAR, T.; CROCK, B.N., op.cit., p. 27.
} 
vendas, além disso, estão psicologicamente traumatizados. Os corpos dos mortos são mutilados, queimados ou jogados ao mar. ${ }^{420}$

A demora entre a denúncia e a punição do crime varia de acordo com o grau de autoritarismo do regime sustentado por um governo que faz uso da tortura. Somente com a deposição dessas autoridades a sociedade civil é impulsionada a se reorganizar. Em alguns momentos, outra dificuldade surge quando as associações médicas e os Conselhos de Medicina expressam afinidades com os regimes autoritários e auxiliam-nos a dissimular o envolvimento de profissionais de saúde nos casos de abusos. Tudo é arquitetado para concessão de anistia aos envolvidos. ${ }^{421}$

O presente estudo trouxe à luz o fato de a tortura necessitar da ciência médica para funcionar e se especializar. O médico cria métodos, disfarça cicatrizes, mantém o interrogado vivo e oculta a causa de morte, se houver. O poder de licenciar médicos, não raro, está mais ligado ao governo torturador do que às associações médicas, as quais, por sua vez, se encontram mais próximas à sociedade civil, contrária à tortura. Nos casos latino-americanos, as associações médicas, criativamente, conseguiram punir alguns envolvidos, devido à posse de maior autonomia do governo. A Associação Médica Mundial e demais associações internacionais deveriam criar estratégias firmes para ajudar as associações nacionais a responsabilizar os envolvidos. Os grupos informais de Direitos Humanos também desempenham importante papel, uma vez que conduzem os envolvidos ao julgamento perante uma Corte. Das Cortes internacionais não se alcança muito apoio, porque o foco é lançado aos oficiais seniores do governo (mandantes dos atos) e não aos funcionários de uma prisão, por exemplo, os médicos torturadores. No estado da Califórnia (EUA) foi aprovada uma resolução que solicita às juntas médicas informar aos médicos licenciados o fato de o auxílio em tortura enquadrar crime. ${ }^{422}$

No tocante ao Direito Internacional, a circunstância que exige sua petição envolve um grande número de pessoas vítimas de abusos e maus-tratos por profissionais de saúde. Em 1999, o juiz espanhol Baltazar Garzón buscou mecanismos de Direito Internacional para extraditar membros das Forças de Segurança argentinas, incluindo três médicos, por crimes contra a humanidade. ${ }^{423}$ A tortura é um crime por si só, mas também pode ser considerada crime contra a humanidade.

\footnotetext{
${ }^{420}$ MILES, S.H.; ALENCAR, T.; CROCK, B.N.; op.cit., p. 28.

${ }^{421}$ MILES, S.H.; ALENCAR, T.; CROCK, B.N.; op.cit., p. 28.

${ }^{422}$ MILES, S.H.; ALENCAR, T.; CROCK, B.N.; op.cit., p. 29.

${ }^{423}$ The Public Committee against Torture in Israel, Physicians for Human Rights - Israel, op.cit., p. 52.
} 
Miles defende em seu artigo que para a tortura não integrar a história da Medicina é necessário a construção de mais esforços em Direitos Humanos. As distintas ações que resultaram em punições a médicos em países vários é algo que precisa ser divulgado amplamente.

A criação de um site com informações em arquivos, nomes e o andamento dos processos, certamente ajudaria o desenvolvimento dessas noções em associações médicas, Conselhos de Medicina, sociedades médicas e grupos de Direitos Humanos. Alertando, ainda, governos e médicos que acreditam na impunidade de seu envolvimento com tortura. Sua manutenção caberia a uma organização de Direitos Humanos ou à Associação Médica Mundial, que lidam com a tortura e o tratamento dos respectivos sobreviventes. A concepção de um Tribunal Internacional para investigação de tortura, cujo intuito seria apurar evidências e investigá-las, todavia, conforma uma realidade distante, especialmente, no sentido de um indivíduo ou instituição responsável por sua fundação e manutenção. Apesar das dificuldades, é importante considerar essas ideias para se por um fim à participação médica nos atos de tortura. ${ }^{424}$

Para Peter Hall, diretor da organização "Médicos pelos Direitos Humanos", em artigo de dezembro de 2011, do The Lancet, a falha em penalizar os médicos que se envolvem com tortura implica em duas perdas. Primeiro, tal atitude não constitui apenas uma infração ética, trata-se de um crime hediondo internacional, acordado por todos os Estados como uma norma de direito cogente, em outras palavras, a tortura é inaceitável universalmente, independente da assinatura ou não um tratado. Dessa forma, as raras punições desde a Segunda Guerra Mundial foram disciplinares, é absurdo, no entanto, o fato de poucos terem respondido por isso. A ausência de uma apuração e penalização oriunda de uma Corte internacional ou tribunal ad hoc tornam a situação ainda mais agravante, uma vez que todo crime de tortura deixa uma vítima merecedora de justiça restorativa, assegurar a punição do perpetrador se torna um componente essencial. Os surrados argumentos "Eu obedecia às Forças Armadas, tive um problema de dupla lealdade. Lamento em não ter priorizado o bem-estar dos meus pacientes" não são suficientes. ${ }^{425}$ Inclusive, desde 1997, a Associação Médica Mundial divulgou uma declaração segundo a qual um médico envolvido com tortura e outros crimes contra a

\footnotetext{
${ }^{424}$ MILES, S.H.; ALENCAR, T.; CROCK, B.N.; op.cit., p. 30.

${ }^{425}$ HALL, P., "Doctors and torture, victims and justice", The Lancet, v. 378, Issue 9809, p. 26, 17 December 2011. Disponível em: <http://www.lancet.com/journals/lancet/article/PIIS0140-6736(11)61899-0/fulltext>. Acesso em: 29 jan. 2012.
} 
humanidade não é talhado para tal, além disso, alerta as associações médicas e seus respectivos organismos de licença profissional sobre o dever de os médicos estrangeiros serem investigados profundamente antes da permissão da prática médica em seu país. Afinal, muitos médicos envolvidos em atrocidades conseguiram, em um tempo posterior, fugir de suas condenações e iniciar uma nova carreira em outro país. ${ }^{426}$

De acordo com o relatório de Israel, no caso dos médicos militares comprometidos com a tortura na guerra ao terror, apesar da recriminação pela comunidade médica e de várias organizações mundiais, nenhum foi considerado responsável por seus atos. A partir da publicação das fotos de Abu Ghraib, em 2004, apenas soldados novatos foram julgados, razão que lhes proporcionaram sentenças leves. Nenhum oficial de alto escalão foi convocado para depor ou responsabilizado por suas condutas. Guantánamo configurou um local de "experimento" para as técnicas reforçadas de interrogatório e, surpreendentemente, a Associação Americana de Psicologia estava entre as poucas associações da área de saúde que apoiou as declarações do governo sobre a tortura não ser empregada nesses centros de detenção. Curiosamente, o programa de técnicas reforçadas de interrogatório contou com a participação de psicólogos e psiquiatras para seu uso e aprimoramento. ${ }^{427}$

Da leitura do Relatório da CIA, muitos dos envolvidos com as técnicas reforçadas de interrogatório temiam intimação para responderem por seus atos perante uma Corte internacional. Infelizmente, até o presente momento, os Estados Unidos não ratificaram o Estatuto de Roma e a consequente jurisdição do Tribunal Penal Internacional, mesmo com a garantia de que os atos passados não serão julgados por essa Corte enquanto da assinatura de sua jurisdição. Portanto, sempre se tem em mente a noção de que as técnicas reforçadas de interrogatório ainda são práticas dispensadas. Durante sua campanha presidencial, Barack Obama prometeu o fechamento do presídio de Guantánamo já em seu primeiro ano de mandato, 2009, promessa que até então não se cumpriu. Os motivos, sem dúvida, são políticos, especula-se que se relacionam aos seus desejos de reeleição e ao respeito às vontades da opinião pública. ${ }^{428}$

\footnotetext{
${ }^{426}$ Site da Associação Médica Mundial. Disponível em:

$<$ http://www.wma.net/en/30publications/10policies/c16/>. Acesso em: 29 jan. 2012.

427 The Public Committee against Torture in Israel, Physicians for Human Rights - Israel, op.cit., p. 48.

${ }^{428}$ Site do O Estado de São Paulo. Disponível em:

$<$ http://www.estadao.com.br/noticias/internacional,guantanamo-afeta-reeleicao-de-obama-dizemanalistas, 710832,0.htm>. Acesso em: 29 jan. 2012.
} 
O Tribunal Penal Internacional representa a Corte mais apropriada para os países signatários que cometam atrocidades semelhantes às da Segunda Guerra Mundial, ou melhor, façam uso de experimentos médicos e morte sistematizada de milhares de pessoas. No caso da antiga Iugoslávia e de Ruanda há médicos sendo julgados ainda hoje, mas enquanto países, como Estados Unidos e Israel, que possuem os casos contemporâneos mais explícitos de envolvimento médico com tortura, não aceitarem os princípios dessa jurisdição, a sociedade continuará assistindo aos abusos e a única esperança recairá sobre a pressão de grupos de Direitos Humanos para que as Cortes nacionais e os Conselhos de Medicina apurem e condenem esses atos.

A organização "Médicos pelos Direitos Humanos" (Physicians for Human Rights) pesquisa a tortura, tanto nos Estados Unidos quanto no mundo. Trata-se de uma Organização Não Governamental independente, sem fins lucrativos, que usa de conhecimento médico e científico para investigar violações de Direitos Humanos, além de lutar por justiça, responsabilização e pela saúde e dignidade de todos os indivíduos. Essa organização divulga muitas medidas com intuito de superar a conjuntura norte-americana e evitar a repetição dos episódios da guerra contra o terror.

Ao mesmo tempo, a organização "Centro de Justiça e Responsabilidade - Trazendo justiça aos abusadores de Direitos Humanos” (The Center for Justice \& Accountability Bringing human rights abusers to justice - CJA) trabalha para que os envolvidos com tortura respondam por seus atos. Em 2010 o Dr. Steven Reisner, psicólogo e supervisor do Programa Internacional de Estudos de Trauma em Nova York, promoveu uma denúncia junto do Centro de Justiça e Responsabilidade contra o Dr. John Leso, outro psicólogo. A denúncia transferida para o Escritório de Disciplina Profissional de Nova York (New York Office of Professional Discipline) alegava que o Dr. John Leso fez parte do grupo BSCTs, mencionado no Capítulo V, entre 2002 e 2003, no qual empregou os conhecimentos em Psicologia para explorar as fraquezas dos detentos de Guantánamo induzindo-os a cooperarem nos interrogatórios. Não só participou do interrogatório de al-Qahtani, como também aconselhou o uso de técnicas abusivas, degradantes para diminuir as capacidades cognitivas dos detentos e aumentar a sensação de sofrimento, com objetivo de modificar os seus comportamentos, intimidá-los e puni-los. A denúncia-reclamação (“complaint”) 
apresenta 28 páginas, ao final das quais se requere investigação dos fatos e apropriada ação disciplinar, incluindo a revogação de sua licença como psicólogo. ${ }^{429}$

Em agosto de 2011, o caso de John Leso foi rejeitado por uma Corte local do estado de Nova York, onde o Escritório de Disciplina Profissional se recusou a investigar o caso, quando solicitado por Steven Reisner, sob alegação da falta de competência legal do questionamento feito por Reisner no que diz respeito à decisão do Escritório. A juíza Saliann Scarpulla da Suprema Corte de Justiça comentou o seguinte: "Eu me sensibilizo com a atitude de Reisner, mas há uma grande implicação moral aqui”. Apesar de se sensibilizar com o gesto do psicólogo, ela concordou com a negativa da Corte baseada na tecnicalidade da ausência de competência. As Juntas de Psicologia dos estados da Califórnia, Louisiana, Ohio e Texas também rejeitaram recentemente denúncias de outros psicólogos envolvidos com tortura em Guantánamo. ${ }^{430}$

Referidas decisões desestimulam a crença de que os envolvidos com os abusos da guerra contra o terror serão eventualmente punidos por seus atos. Em contrapartida, dois estados norte-americanos, Massachusetts e Nova York, apresentam iniciativas producentes, a começar pelo apoio da organização "Médicos pelos Direitos Humanos". O Projeto de Lei H.3361/S.1090, em Massachusetts, proposto pelo parlamentar estadual Jason Lewis e pelo senador estadual James B. Eldridge, intitula-se "Ato que proíbe a participação de profissionais da área de saúde em tortura e maus-tratos a prisioneiros". Esse projeto pretende sancionar os profissionais de saúde, licenciados pelo estado, que participem de tratamento abusivo ou torturante de detentos e providenciar proteção aos profissionais que se recusam a participar da tortura ou querem investigá-la. ${ }^{431}$

Também nesse sentido, o estado de Nova York, por meio de proposição do deputado estadual Richard Gottfried e do senador estadual Tom Duane, intitulou o seguinte ato: "Ato para emendar a lei de saúde pública, a educação da saúde e o trabalho da saúde, em relação a proibir participação em tortura e tratamento inadequado de prisioneiros por profissionais da área de saúde". Similar ao projeto de lei de Massachusetts, pretende impedir que profissionais de saúde se envolvam com tortura e outros tratamentos

\footnotetext{
${ }^{429}$ Site do The Center for Justice \& Accountability - Bringing human rights abusers to justice - CJA. Case John Leso. Disponível em: <http://cja.org/article.php?list=type\&type=412>. Acesso em: 27 jan. 2012. ${ }^{430}$ Site do Physicians for Human Rights. New York Court refuses to look at psychologist's role at Guantanamo. Disponível em: < http://physiciansforhumanrights.org/blog/new-york-court-refusal.html>. Acesso em: 27 jan. 2012.

${ }^{431}$ Site do Physicians for Human Rights. MA and NY Legislation to sanction health professionals who torture. Disponível em: $<$ http://physiciansforhumanrights.org/issues/torture/us-torture/ma-and-ny-antitorture-legislation.html>. Acesso em: 27 jan. 2012.
} 
degradantes aos presos. Além disso, requer desses profissionais a denúncia das ocorrências desses abusos para as autoridades competentes e a providência de proteção aos delatores ou aos indivíduos que desejam, por algum motivo, investigar. ${ }^{432}$

Ambas as legislações pretendem aclarar o impedimento da participação de profissionais de saúde com tortura e outros abusos, inclusive, a modo de proteção preventiva, interrompendo por completo que profissionais de saúde responsáveis pela custódia de presos sejam convocados para trabalhar junto a interrogatórios. Ademais, as leis anseiam apurar fatos ocorridos fora do território em questão, a fim de apenar o culpado e preservar a reputação do estado, de onde tem origem sua respectiva licença médica. ${ }^{433}$

Caso esses projetos de lei sejam aprovados no Congresso norte-americano há esperança de que no futuro os médicos de ambos estados não participem de tortura, em um horizonte ainda mais amplo aspira-se influenciar os outros 48 estados da federação estadunidense a criarem legislação semelhante. Há passos importantes sendo tomados para o retorno de uma prática médica de acordo com os princípios bióeticos da não maleficência e beneficência nos Estados Unidos, especialmente, no tocante ao tratamento dos presos.

Nesse contexto, há o esforço de se criar uma legislação que proteja os imigrantes detidos em terreno norte-americano. Grupos de Direitos Humanos têm denunciado violações contra esses indivíduos detidos, por exemplo, falta de acesso à saúde, violência sexual e morte. É incumbência dos médicos que trabalham nesses centros de detenção considerar o bem-estar do paciente em primeiro plano, entretanto, manter essa lealdade se volta complexo, porque o Serviço de Segurança Nacional obriga o médico a satisfazer os interesses do Estado. Tendo em vista o dilema da dupla lealdade, a organização "Médicos pelos Direitos Humanos" criou um relatório, em março de 2011, para ajudar os médicos que se veem confusos e oferecer táticas para manter a ética médica viva nessas penitenciárias. ${ }^{434}$ Portanto, nos Estados Unidos, mesmo internamente, observa-se uma preocupação do médico em ser coagido a torturar um detento em troca de informações.

Outra inovação que consta do site "Médicos pelos Direitos Humanos" é um manual, cujo conteúdo ensina como o médico deve tratar uma vítima de tortura e documentar as evidências, essa obra, além de ser indicada em seminários e palestras,

\footnotetext{
${ }^{432}$ Site do Physicians for Human Rights. MA and NY Legislation to sanction health professionals who torture, op.cit., p. 1.

${ }^{433}$ Site do Physicians for Human Rights. MA and NY Legislation to sanction health professionals who torture, op.cit., p. 1.

${ }^{434}$ Site do Physicians for Human Rights. Dual loyalties in US Immigration Detention. Disponível em: $<$ http://physiciansforhumanrights.org/issues/torture/asylum/dual-loyalties-immigration-detention.html $>$. Acesso em: 27 jan. 2012.
} 
pretende educar os futuros médicos e é semelhante e conforme ao Protocolo de Istambul. Contém fotos detalhadas de lesões, o que ajuda na averiguação. ${ }^{435}$

Leonard S. Rubenstein e Melanie D. Bittle, em artigo no The Lancet, propõem que a melhor organização internacional para solucionar o problema do envolvimento médico com tortura é a Organização Mundial de Saúde - OMS, que poderia documentar os abusos cometidos por esses profissionais. Ademais é proposta uma resolução da ONU que determine à OMS o mandato para conduzir investigações e o uso de aparelhos celulares que transmitam de forma segura e eficiente informações de abuso. A documentação do envolvimento médico com tortura constitui tema ao qual se deve dispensar autoridade, desse modo se torna um incentivo de recusa aos médicos que sofrem pressões governamentais e hierárquicas para auxiliar as violações. ${ }^{436}$

Em fevereiro de 2010 foi publicado um artigo que faz referência à resolução do Conselho de Direitos Humanos da ONU, aceita em 2009, por influência do Dr. Peter Polatin, do "Centro de reabilitação e pesquisa de vítimas de tortura" na Dinamarca. Essa resolução ajudaria a combater a cumplicidade médica com a tortura, nesse sentido, sua força precisa ser reforçada, em especial, na função investigativa, para assegurar que os responsáveis sofram penas disciplinares. ${ }^{437} \mathrm{Na}$ realidade, não faltam tratados e legislações sobre esse assunto, o problema reside justamente em sua eficácia. A criação de uma resolução da ONU configura um importante instrumento, mas até que se percebam esforços no mundo concreto servirá apenas como objeto de estudo e não como um fator verdadeiramente impeditivo da tortura médica.

Além disso, os escritos de Rubenstein e Bittle concordam que em teoria tudo parece muito simples, no entanto, o desafio real consiste em forçar os médicos a não violarem os preceitos éticos em prol da tortura, além, é claro, de punir os profissionais que já se encontram envolvidos. $\mathrm{O}$ fato de a Medicina ser uma profissão autorregulatória dificulta a penalização universal de um médico, não impedindo que ele migre para outro país, forje uma nova identidade e pratique a ciência em novo território, em vista disso, é

${ }^{435}$ Site do Physicians for Human Rights. Document Torture Internationally. Disponível em: $<$ https://sites.google.com/a/physiciansforhumanrights.org/model-curriculum-on-the-effective-medicaldocumentation-of-torture-and-ill-treatment/model-curriculum-on-the-effective-medical-documentation-oftorture-and-ill-treatment>. Acesso em: 27 jan. 2012.

${ }^{436}$ RUBENSTEIN, L.S.; BITTLE, M.D., "Responsibility for protection of medical workers and facilities in armed conflict”, The Lancet, v. 375, Issue 9711, pp. 329-340, 23 January 2010, p. 337. Disponível em: $<$ http://www.thelancet.com/journals/lancet/article/PIIS0140-6736(09)61926-7/fulltext?_eventId=login $>$. Acesso em: 27 jan. 2012.

${ }^{437}$ Site Science Daily. "Could a new UN resolution end doctor`s participation in torture", BMJ - British Medical Journal, 25 February 2010. Disponível em:

$<$ http://www.sciencedaily.com/releases/2010/02/100225214808.htm>. Acesso em: 29 jan. 2012. 
indispensável a existência de um canal de informação internacional para divulgar os médicos que se envolvem com tortura. Há relatos de clínicos de Ruanda que escaparam e atuam em outros países da África e Europa. ${ }^{438}$

Uma questão discutida por Steve J. Hoffman traz à tona o contrato de médicos por parte do governo para auxiliar a tortura, dispensando todas as influências para mantê-los imunes à perseguições penais e disciplinares, também com o intuito velado de não comprometerem suas próprias políticas, fato que conota a necessidade de maior vigor das leis. Segundo Hoffman, os organismos que punem indivíduos e não Estados, por exemplo, o Tribunal Penal Internacional, não são eficazes em razão de determinados Estados protegerem seus cidadãos torturadores, assim, a jurisdição universal apoia parcialmente a luta contra o envolvimento médico com tortura. Enquanto os Estados não respeitam esse aspecto legal, uma das saídas se daria por meio de alternativas informais, como incluir na grade horária da educação médica de graduação e pós-graduação os cursos de ética médica e Direitos Humanos. Os médicos militares poderiam receber um treinamento ético e reforçar sua missão com um trabalho verdadeiramente apropriado. Além disso, a divulgação dos médicos punidos por compactuarem com a tortura desencoraja os profissionais que se veem tentados a participarem da tortura. Particularmente, o médico pode cooperar documentando os casos de lesões advindas de abuso e, em seguida, denunciando-os, de modo a incitar a atenção do governo, dos Conselhos de Medicina, das associações médicas e dos grupos de Direitos Humanos, cada qual representa um papel na "guerra contra a tortura". 439

Outro ponto não tratado em artigos ou livros, mas merece discussão é a figura do médico que concorda em participar da tortura a fim de obter uma vantagem econômica. Nos Estados Unidos a possibilidade de um médico compactuar com a tortura decorre do receio de custear sua educação médica, financiada pelo Exército. Em situações de evidente corrupção se oferece propina ao médico que de início se recusa a cooperar e/ou participar da tortura. Apesar do enorme dilema moral, ele aceita a proposta com a cláusula de proteção da sua pessoa e dos seus atos, além de, no futuro, não responder por crimes perante alguma Corte especializada. Afinal, no universo médico, pelo menos no Brasil, encontram-se clínicos que desviam sua função tendo em vista objetivos econômicos. Há o

\footnotetext{
${ }^{438}$ RUBENSTEIN, L.S.; BITTLE, M.D., op.cit., p. 340.

${ }^{439}$ HOFFMAN, S.J., "Ending medical complicity in state-sponsored torture", The Lancet, v. 378, Issue 9802 , 29 October 2011, pp. 1535-1537. Disponível em: $<$ http://www.thelancet.com/journals/lancet/article/PIIS0140-6736(11)60816-7/fulltext?_eventId=login>. Acesso em: 29 jan. 2012.
} 
médico que concorda em realizar o aborto por vultosa quantia, mesmo enquadrando um crime conforme a Legislação Penal brasileira ou "comercialize" receitas de remédios controlados. Nesse contexto, é evidente, apesar da ausência em pesquisas, a atuação de médicos no auxílio à tortura para obter um ganho monetário.

Em 26 de janeiro de 2012, a organização internacional Médicos Sem Fronteiras MSF (Doctors without borders/ Medecins san frontieres), publicou uma notícia ratificando a suspensão do atendimento médico aos detentos que sofrem tortura na Líbia, especificamente em Misrata. A organização iniciou seus trabalhos na região em agosto de 2011 para tratar detentos com ferimentos de guerra. Muitos pacientes apareciam com lesões adquiridas de interrogatórios com tortura, realizados fora do centro de detenção. Foram relatados para as autoridades de Misrata, 115 casos vítimas de abusos, entretanto, desde janeiro de 2012, os detentos que retornaram aos centros de interrogatório sofreram tortura.

Alguns oficiais desses centros tentaram explorar os serviços dos médicos da MSF, solicitando tratamento na medida em que se davam os interrogatórios, o pedido, óbvio, foi terminantemente refutado. A organização solicitou a transferência de vários detentos para hospitais, muitos foram negados a modo de castigo e vingança. Após tentativa de solução com diferentes autoridades, em 9 de janeiro de 2012 a associação enviou uma carta ao Conselho Militar de Misrata, Comitê de Segurança, Serviço de Segurança do Exército Nacional e Conselho Civil Local, exigindo o término imediato dos abusos cometidos com os presidiários. Nenhuma atitude foi tomada e logo em seguida mais quatro casos de tortura apareceram. Portanto, a MSF decidiu suspender suas atividades médicas nos centros de detenção de Misrata, no entanto, a sua atuação prossegue em outros locais da Líbia. $^{440}$

Parece um pouco dramático a ausência de tratamento a pacientes que carecem de assistência, talvez, essa seja a única forma de interromper a tortura em ambiente de conflitos armados, onde a população é alvo de violentos interrogatórios. Não constituiria o abandono do paciente outro modo de maleficência? A médica Chiara Lepora, que trabalhou na organização "Médicos sem Fronteiras", considera esse dilema terrível, pois em qualquer aspecto a cumplicidade com a tortura é inaceitável. Entretanto, essa

\footnotetext{
440 Site da organização Médicos sem fronteiras. Libya: Detainee tortured and denied medical care - MSF suspends work in detention centers in Misrata. Disponível em: $<$ http://www.doctorswithoutborders.org/press/release.cfm?id=5744\&cat=press-release $>$. Acesso em: 27 jan. 2012.
} 
cumplicidade pode se apresentar em diversos níveis, corroborando o dever médico de avaliar todos os fatores, por exemplo, se o detento torturado requer um tratamento, não pode o profissional recusá-lo. O conselho comum, nessas circunstâncias, é tornar-se cúmplice da tortura, oferecendo o devido tratamento. Seria a escolha mais beneficente. Lepora e Joseph Millum recomendam que o médico dispense cuidados e apoio a esses pacientes, além de inventar um papel de ajuda à sociedade no combate à tortura. Como fazê-lo? A coleta e documentação secreta de dados que evidencie o emprego de tortura no local pode ajudar os grupos de Direitos Humanos que fiscalizam essas instituições. Segundo os autores as fontes de evidências normalmente são dos médicos coagidos, mas os estudiosos demonstram o cuidado de afirmar que suas opiniões são apenas uma recomendação e está longe de se tornar uma lei, que significaria carta branca para que os médicos torturem e, em seguida, documentem, se isentando de qualquer responsabilidade ética ou penal. ${ }^{441}$

A solução mais equilibrada conformaria uma construção caso a caso, em que as questões morais devem estar em um patamar inferior ao princípio da beneficência e da não maleficência. A conduta da MSF na Líbia se volta arriscada e pode significar a morte de detentos carentes de tratamento a fim de um dia figurarem como vozes ativas no protesto pela extinção da tortura. Esse suposto abandono pode ser tão grave quanto a cumplicidade com a tortura. Se os médicos tratassem os prisioneiros e conseguissem tomar nota dos abusos cometidos em segredo estariam praticando uma conduta benéfica também a longo prazo. É sabido que não são escolhas fáceis, mas o essencial é cada médico consultar sua consciência e os princípios bioéticos a fim de tomar as decisões mais prudentes e que signifiquem menores danos ao paciente.

\section{b) Conclusões}

Ante todo o exposto, concluí-se pela inexistência de uma solução única para a questão dos médicos envolvidos com tortura e sua consequente e tão presente impunidade. Não se deve confiar somente na atuação do governo, ou de uma organização ou tribunal. Talvez, a resposta esteja na divulgação das informações sobre o assunto e no trabalho em

\footnotetext{
${ }^{441}$ Site Science Daily. LEPORA, C.; MILLUM, J., "The tortured patient: a medical dilemma", Hastings Center Report, v. 41, n. 3, 9 May 2011. Disponível em:

$<$ http://www.sciencedaily.com/releases/2011/05/110509151248.htm>. Acesso em: 29 jan. 2012.
} 
cooperação de organizações producentes, a saber: ONU, Médicos sem fronteiras, Médicos pelos Direitos Humanos, Organização Mundial de Saúde, Associação Médica Mundial, Cruz Vermelha, Anistia Internacional, dentre outras, todas junto do governo, das Cortes nacionais e internacionais, e dos conselhos de Medicina.

A conjugação de esforços globais deve se dar no sentido de educar as gerações futuras de médicos para a reconquista dos valores da Bioética. Os profissionais de saúde que se encontram pressionados para torturar devem ser protegidos por algum órgão nacional ou internacional para que a omissão por medo deixe de constituir prática comum, referida proteção também se estende aos delatores e as suas famílias, além de uma recompensa que os motivem. A educação sobre a documentação de evidências de tortura deveria integrar a grade das faculdades de Medicina. A sociedade civil ao se manifestar desempenha um papel importante para a aceitação do desaparecimento de familiares e para os cuidados com as lesões permanentes dos sobreviventes.

Diante de um cenário de tortura o clínico deve se pautar segundo os princípios da beneficência, não maleficência e autonomia de modo a tomar decisões que proporcionem os maiores benefícios ao paciente. Quando coagido violentamente, é sua obrigação cuidar do presidiário torturado e documentar as lesões conforme o Protocolo de Istambul. Essa documentação deve ser sigilosa e cautelosa, pois significa riscos ao médico. A denúncia e a entrega de documentos por parte do médico se dão justamente quando da visita de uma entidade de Direitos Humanos, por exemplo, a Cruz Vermelha. O profissional externo ao visitar essas instituições deve estar atento às evidências de violência de acordo com o referido Protocolo, além do exame das condições de higiene e alimentação. No universo da tortura, a missão e o juramento de Hipócrates se voltam complexos, ainda assim não se deve renunciar aos seus princípios em nome de uma ideologia política, militar ou mesmo econômica.

A participação médica na tortura deve ser investigada e devidamente apurada. Dependendo do nível, o médico carece sofrer uma sanção e ter sua licença revogada, (pena disciplinar), além de responder pelo crime cometido, inclusive, com pena de detenção e reparação monetária para a vítima e sua família. É incabível uma visão reducionista da gravidade de seu ato criminoso e da respectiva infração ética, se trata de ambos concomitantemente. Dessa forma, as Cortes criminais e Conselhos de Medicina têm a responsabilidade de atuarem, conjunta ou individualmente, para penalizar os culpados. A 
impunidade, todavia, integra a história contemporânea, mas se os esforços conjuntos forem realizados, é possível modificá-la.

O envolvimento médico com tortura ainda existe na realidade de muitos países, as lições da Segunda Guerra Mundial não foram suficientes para impedir que o médico revisitasse um novo papel no uso da maleficência. Portanto, a única forma de a nova geração de profissionais se dedicarem somente à missão da Medicina é enxergar o problema e não se deixar cegar, divulgá-lo e unir esforços para que os envolvidos sejam devidamente punidos. Apesar dos inúmeros avanços, o sistema de saúde carece de infraestrutura para impedir por completo as novas ocorrências de médico com a tortura. Por tudo o que foi considerado, os estudantes de Medicina devem lançar um olhar ao passado para compreender o presente e prevenir o futuro de novos abusos e violações dos princípios da Bioética. 


\section{VII - REFERÊNCIAS BIBLIOGRÁFICAS}

AMARAL JÚNIOR, A., Curso de Direito Internacional Público, $2^{\mathrm{a}}$ ed., São Paulo, Editora Atlas, 2011.

ARENDT, H., Eichmann em Jerusalém - Um relato sobre a banalidade do mal, 10ª reimp., São Paulo, Companhia das Letras, 2010.

BEAUCHAMP, T.L.; CHILDRESS, J.F., Princípios de Ética Biomédica, 2a ed., São Paulo, Edições Loyola, 2011.

BREWER, S.E.; ARRIGO, J.M., "Places that medical ethics can't find: Preliminary observations on why health professionals fail to stop torture in overseas counterterrorism operations", In: Interrogations, forced feedings, and the role of health professionals: New perspectives on international human rights, humanitarian law, and ethics, Edited by Ryan Goodman and Mindy Jane Roseman, Human Rights Program, Harvard Law School, Cambridge, Massachusetts, United States, Signature Book Printing, 2009.

BUTLER, J., "O limbo de Guantánamo", Novos estud. - CEBRAP [online]. 2007, n. 77, pp. 223-231, ISSN 0101-3300, p. 223. Disponível em: $<$ http: $/ /$ www.scielo.br/scielo.php? script $=$ sci arttext\&pid $=S 0101-$ 33002007000100011>. Acesso em: 28 jan. 2011.

CENTRAL INTELLIGENCE AGENCY, "Office of Inspector General. Draft Office of Medical Services Guidelines on Medical and Psychological Support to Detainee Interrogations" (2003) Special Review. Counterterrorism Detention and Interrogation Activities. Central Intelligence Agency. Disponível em: $<$ http://www.gwu.edu/ nsarchiv/torture_archive/20040507.pdf $>$. Acesso em: 20 jan. 2012.

CAMARGO, R.A.E.; CAMPOS, R.A.C., "A Bioética e seus Reflexos no Direito", Âmbito Jurídico, v. 37, p. 1, 2007. Disponível em: <http://www.ambitojuridico.com.br/site/index.php?n_link=revista_artigos_leitura\&artigo_id=1706 $>$. Acesso em: 14 jul. 2011.

CRETELLA NETO, J., Curso de Direito Internacional Penal, Ijuí, Editora Unijuí, 2008.

CONDE, F.M., Edmund Mezger e o Direito Penal de seu Tempo - Estudos sobre o Direito penal no nacional-socialismo, Rio de Janeiro, Editora Lumen Juris, 2005.

DINIZ, M.H., O Estado Atual do Biodireito. $2^{\mathrm{a}}$ ed., São Paulo, Editora Saraiva, 2002. 
ESTATUTO do Tribunal de Nuremberg, em espanhol. Disponível em: $<$ http://www.ehu.es/ceinik/tratados/7TRATADOSRELATIVOSACRIMENESDEGUERR A/CG73.pdf $>$. Acesso em: 28 jun. 2010.

ESTATUTO de Roma, em português. Disponível em: $<$ http://www.fd.uc.pt/CI/CEE/OI/TPI/Estatuto_Tribunal_Penal_Internacional.htm $>$. Acesso em: 28 jun. 2010.

FEIO, A.G.O.; OLIVEIRA, C.C., "Responsabilidade e Tecnologia: a Questão da Distanásia", Revista Bioética, CFM, v. 19, n. 3, 2011. Disponível em:

$<$ http://revistabioetica.cfm.org.br/index.php/revista_bioetica/issue/view/40>. Acesso em: 25 jan. 2012.

FERRARI, E. R., Medidas de Segurança e Direito Penal no Estado Democrático de Direito, São Paulo, Editora Revista dos Tribunais, 2001.

FISK, R., "The forgotten holocaust", The Independent, 2007. Disponível em: $<$ http://www.independent.co.uk/opinion/commentators/fisk/robert-fisk-the-forgottenholocaust-463306.html >. Acesso em: 28 jun. 2010.

FLORENTINO FERNANDEZ JANKOV, F., Direito Internacional Penal - Mecanismos de Implementação do Tribunal Penal Internacional, São Paulo, Editora Saraiva, 2009.

FORREST, D., "Examination following specific forms of torture", In: The medical documentation of torture, Edited by Michael Peel and Vicent Iacopino, New York, Cambridge University Press, 2009.

FURTADO MAIA NETO, C., "Direito Penal Internacional e Direito Internacional Penal", Site Direitos Humanos Aplicados. Disponível em: <http://www.direitoshumanos.pro.br/artigos.php?id=93 $>$. Acesso em: 26 jun. 2011.

GARRAFA, V., "Bioética e Ciência - Até onde avançar sem agredir", In: COSTA, Sérgio Ibiapina Ferreira, GARRAFA, Volnei, OSELKA, Gabriel, (Orgs.), Iniciação à Bioética, Publicação do Conselho Federal de Medicina, Brasília, 1998. Disponível em: $<$ http://www.portalmedico.org.br/biblioteca virtual/bioetica/indice.htm $>$. Acesso em: 11 jan. 2012.

GOLDHAGEN, D.J., Os carrascos voluntários de Hitler: o povo alemão e o Holocausto, São Paulo, Companhia das Letras, 1997, p. 279.

GOLDIM, J.R., "Bioética e Complexidade", In: COSTA, Judith Martins, MÖLLER, Letícia Ludwig (Orgs.), Bioética e responsabilidade, Rio de Janeiro, Forense, 2009.

Código de Nuremberg. Disponível em:

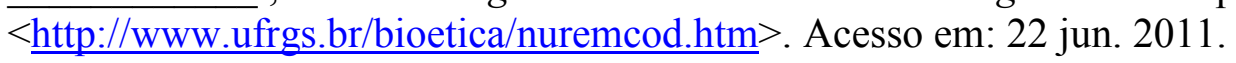
., Eutanásia - Alemanha Nazista 1939-1941. Disponível em: $<$ http://www.ufrgs.br/bioetica/eutnazi.htm>. Acesso em: 13 dez. 2011. 


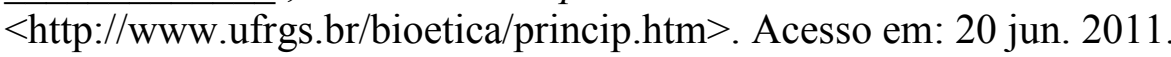

HALL, P., "Doctors and torture, victims and justice", The Lancet, v. 378, Issue 9809, p.

26, 17 December 2011. Disponível em:

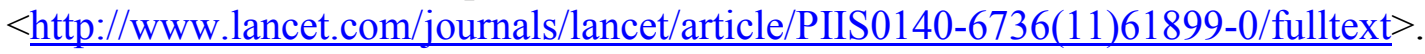

Acesso em: 29 jan. 2012.

HIPÓCRATES, Juramento de. Disponível em: $<$ http://www.cremesp.org.br/?siteAcao=Historia\&esc=3 $>$. Acesso em: 01 nov. 2009.

HOFFMAN, S. J., "Ending medical complicity in state-sponsored torture", The Lancet, v. 378, Issue 9802, 29 October 2011, pp. 1535-1537. Disponível em: $<$ http://www.thelancet.com/journals/lancet/article/PIIS0140-6736(11)60816-

7/fulltext? eventId=login>. Acesso em: 29 jan. 2012.

IACOPINO, V.; XENAKIS, S.N., "Neglect of Medical Evidence of Torture in Guantánamo Bay: A Case Series", PLos Medicine, v. 8, Issue 4, April 2011, p. 2. Disponível

$<\underline{\text { http://www.plosmedicine.org/article/info\%3Adoi\%2F10.1371\%2Fjournal.pmed.1001027 }}$

>. Acesso em: 14 jul. 2011.

IKAWA, D.R., "Convenção contra a tortura e outros tratamentos ou penas cruéis, desumanos ou degradantes (1984)", In: ALMEIDA, Guilherme Assis de, PERRONEMOISÉS, Cláudia (Coords.), Direito Internacional dos Direitos Humanos: instrumentos básicos, $2^{\mathrm{a}}$ ed., São Paulo, Editora Atlas, 2007.

KIRSCHNER, R.; PEEL, M., "Physical Examination for late signs of torture", In: The medical documentation of torture, Edited by Michael Peel and Vicent Iacopino, New York, Cambridge University Press, 2009.

KIPPER, D.J.; CLOTET, J., "Princípios da Beneficência e Não Maleficência", In: COSTA, Sérgio Ibiapina Ferreira, GARRAFA, Volnei, OSELKA, Gabriel, (Orgs.), Iniciação à Bioética, Publicação do Conselho Federal de Medicina, Brasília, 1998. Disponível em: <http://www.portalmedico.org.br/biblioteca virtual/bioetica/indice.htm>. Acesso em: 11 jan. 2012.

KOLKER, T., "Os profissionais da saúde e as torturas nas prisões", Revista Saúde e Direitos Humanos, Ministério da Saúde. Fundação Oswaldo Cruz, Núcleo de Estudos em Direitos Humanos e Saúde Helena Besserman, ano 2, n. 2, Brasília, 2005. Disponível em:

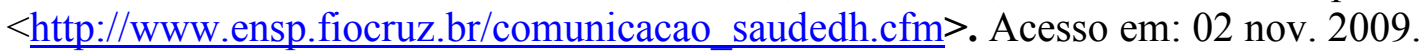

KOVACS, M.J., Bioética nas Questões de Vida e Morte, Universidade de São Paulo, 2002. Disponível em:

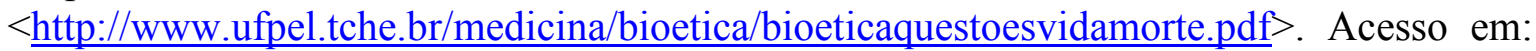
25 jan. 2012.

LEMOS, A.I., Desafia o nosso peito - resistência, tortura e morte durante o regime militar brasileiro: as quedas na guerrilha urbana e os desaparecidos na insurreição do Araguaia: subsídios para a Comissão da verdade, Rio de Janeiro, Editora Consequência, 2011. 
LIFTON, R.J., "Doctors and Torture", The New England Journal Of Medicine, pp. 351355, 29 July 2004. Disponível em: $<$ http://www.nejm.org/doi/full/10.1056/NEJMp048065\#t=article $>$. Acesso em: 17 jul. 2011.

., The Nazi Doctors: Medical Killing and the Psychology of Genocide, Basic Books, United States of America, 1986. Disponível em: $<\underline{\text { http: } / / \text { www.holocaust- }}$ history.org/lifton/LiftonT016.shtml>. Acesso em: 20 jun. 2011.

MAIO, G., "History of medical involvement in torture - then and now", The Lancet, v. 357, Issue 9268, 19 May 2001, pp. 1609-1611. Disponível em: $<$ http://www.thelancet.com/journals/lancet/article/PIIS0140-6736(00)04729-2/fulltext $>$.

Acesso em: 12 jul. 2011.

MARKS, J.H., "Looking back, thinking ahead: the complicity of health professionals in detainee abuse", In: Interrogations, forced feedings, and the role of health professionals: New perspectives on international human rights, humanitarian law, and ethics, Edited by Ryan Goodman and Mindy Jane Roseman, Human Rights Program, Harvard Law School, Cambridge, Massachusetts, United States, Signature Book Printing, 2009.

MARSICANO, J.A.; RAMOS JUNIOR, E.S.; ASSUMPÇÃO, T.S.; SALES PERES, S.H.C.; SALES PERES, A., "Pesquisa em seres humanos: aspectos médicos, jurídicos, psicológicos e religiosos", Revista Gaúcha de Odontologia, v. 56, n. 3, pp. 327-332, Porto Alegre, jul/set. 2008. Disponível em:

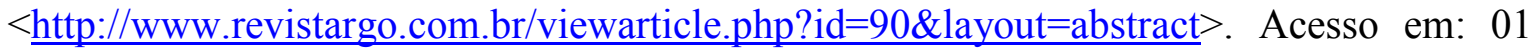
nov. 2009.

MARTIN, L.M., Os Direitos Humanos nos Códigos Brasileiros de Ética Médica: ciência, lucro e compaixão em conflito, São Paulo, Edições Loyola, 2002.

MASSON, C., Direito Penal Parte Geral, v. 1, 3ª ed., São Paulo, Editora Método, 2010.

MAZZUOLI, V.O., O Tribunal Penal Internacional e o Direito Brasileiro, $3^{\text {a }}$ ed., São Paulo, Editora Revista dos Tribunais, 2011.

MILES, S.H., "Doctors Complicty with torture”, British Medical Journal, 2008, 337:1088. Disponível em: $\quad<$ http://psychoanalystsopposewar.org/blog/2008/07/31/milesdoctors $\% \mathrm{E} 2 \% 80 \% 99$-complicity-with-torture/>. Acesso em: 02 nov. 2009.

.; ALENCAR, T.; CROCK, B.N., "Punishing physicians who torture: A work in progress", v. 20, n. 1, 2010, Journal on Rehabilitation of Torture Victims and Prevention of Torture. Disponível em: $<$ http://www.irct.org/library/torture-journal/backissues/volume-20--no.-1--2010.aspx> $>$. Acesso em: 25 jan. 2012.

.; FREEDMAN, A.M., "Medical ethics and torture: revising the Declaration of Tokyo", The Lancet, v. 373, Issue 9660, 24 January 2009, pp. 344-348. Disponível em: $<$ http://www.thelancet.com/journals/lancet/article/PIIS0140-6736(09)60097-0/fulltext>. Acesso em: 02 nov. 2009. 
.; Oath betrayed: America`s torture doctors, $2^{\mathrm{a}}$ ed., Berkeley and Los Angeles, California, University of California Press, 2009.

MOTA, M.B.; BRAICK, P.R., História: das Cavernas ao Terceiro Milênio, volume único, $1^{\text {a }}$ ed., São Paulo, Editora Moderna, 1997.

NASCIMENTO E SILVA, G.E.; ACCIOLY, H., Manual de Direito Internacional Público, São Paulo, Editora Saraiva, 2002.

NEVES, N.M.B.C.; SIQUEIRA, J.E., “A Bioética no Atual Código de Ética Médica”, Revista Bioética, CFM, v. 18, n. 2, 2010. Disponível em: $<$ http://revistabioetica.cfm.org.br/index.php/revista bioetica/article/view/575/547>.

Acesso em: 08 fev. 2012.

NICHOLL, D.J.; JENKINS, T.; MILES, S.H.; HOPKINS, W.; SIDDIQUI, A.; BOULTON, F.; [et al.], "Biko to Guantanamo: 30 years of medical involvement in torture", The Lancet, v. 370, Issue 9590, 8 September 2007, p. 823. Disponível em: $<$ http://www.thelancet.com/journals/lancet/article/PIIS0140-6736(07)61402-0/fulltext $>$.

Acesso em: 02 nov. 2009.

OZKALIPCI, O., "Physical Examination following allegations of recent torture", In: The medical documentation of torture, Edited by Michael Peel and Vicent Iacopino, New York, Cambridge University Press, 2009.

PERRONE-MOISÉS, C., Direito Internacional Penal: imunidades e anistias, Barueri, Editora Manole, 2012.

PEEL, M.; LUBELL, N.; BEYNON, J., Investigação Médica e Documentação sobre Tortura - Manual para Profissionais de Saúde, $1^{\text {a }}$ ed., Centro de Direitos Humanos, Universidade de Essex, Grã-Bretanha, 2005. Disponível em:

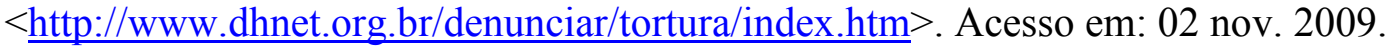

REIS, S.P.; WALD, H.S., "Learning from the past: medicine and the Holocaust", The Lancet, v. 374, Issue 9684, 11 July 2009, pp. 110-111. Disponível em: $<$ http://www.thelancet.com/journals/lancet/article/PIIS0140-6736(09)61275-7/fulltext $>$. Acesso em: 12 jul. 2011.

.; WEINBERG, U., "Medicine's dark past”, StudentBMJ, v. 14, February 2006, p. 46. Disponível em: <http://archive.student.bmj.com/issues/06/02/editorials/46.php>. Acesso em: 12 jul. 2011.

RELATÓRIO do Comitê Internacional da Cruz Vermelha. Disponível em: $<$ http://www.nybooks.com/media/doc/2010/04/22/icrc-report.pdf $>$. Acesso em: 21 jan. 2012.

REYES, H., "Visits to prisoners and documentation of torture", In: The medical documentation of torture, Edited by Michael Peel and Vicent Iacopino, New York, Cambridge University Press, 2009. 
RODRIGO ALFLEN DA SILVA, P., A implementação do estatuto de Roma no âmbito interno brasileiro ante as recentes movimentações no Tribunal Penal Internacional, p. 1. Disponível

$<\underline{\text { http://www.publicacoesacademicas.uniceub.br/index.php/prisma/article/viewFile/841/848 }}$

>. Acesso em: 28 jun. 2010.

RÖGGLA, G.; RÖGGLA, H., "Doctors and torture after Sept 11", The Lancet, v. 359, Issue 9315, 20 April 2002, p. 1440. Disponível em: $<$ http://www.thelancet.com/journals/lancet/article/PIIS0140-6736(02)08384-8/fulltext $>$.

Acesso em: 02 nov. 2009.

ROXIN, C., “A Apreciação Jurídico Penal da Eutanásia”, trad., Luis Greco, Revista Brasileira de Ciências Criminais, ano 8, out.-dez. 2000, São Paulo, Editora Revista dos Tribunais, 2000.

RUBENSTEIN, L.S.; ANNAS, G.J., "Medical ethics at Guantanamo Bay detention centre and in the US military: a time for reform", The Lancet, v. 374, Issue 9686, 25 July 2009, pp. 353-355. Disponível em: <http://www.thelancet.com/journals/lancet/article/PIIS01406736(09)60873-4/fulltext>. Acesso em: 02 nov. 2009.

., "Complicity and the illusion of Beneficence", In: Interrogations, forced feedings, and the role of health professionals: New perspectives on international human rights, humanitarian law, and ethics, Edited by Ryan Goodman and Mindy Jane Roseman, Human Rights Program, Harvard Law School, Cambridge, Massachusetts, United States, Signature Book Printing, 2009.

.; BITTLE, M.D., "Responsibility for protection of medical workers and facilities in armed conflict", The Lancet, v. 375, Issue 9711, pp. 329-340, 23 January 2010. Disponível em: <http://www.thelancet.com/journals/lancet/article/PIIS01406736(09)61926-7/fulltext?_eventId=login>. Acesso em: 27 jan. 2012.

SCHABAS A.W., An Introduction to the International Criminal Court, $3^{\mathrm{a}}$ ed., Cambridge University Press. Disponível em: $<$ http://assets.cambridge.org/97805218/81258/excerpt/9780521881258 excerpt.pdf $>$. Acesso em: 28 jun. 2010.

SILVA, H.C., "Reforma psiquiátrica nas medidas de segurança: a experiência goiana do PAILI", Rev. bras. crescimento desenvolv. Hum., v. 20 n. 1, São Paulo, abr. 2010.

Disponível em: $<$ http://pepsic.bvsalud.org/scielo.php?pid=S0104$\underline{12822010000100015 \& \text { script }=\text { sci_arttext }>}$. Acesso em: 24 jan. 2012.

SITE do Alto Comissariado dos Direitos Humanos das Nações Unidas. Disponível em: $<$ http://www.unhcr.org/refworld/docid/3ae6b36e8.html $>$. Acesso em: 12 jul. 2011.

SITE da Associação Médica Mundial. Disponível em: $<$ http://www.wma.net/en/60about/index.html $>$. Acesso em: 30 jun. 2011.

., Disponível em: $\quad<$ http://translate.googleusercontent.com/translate c?hl=ptBR\&langpair=en\%7Cpt\&rurl=translate.google.com.br\&u=http://www.wma.net/en/30publi 
cations/10policies/c18/index.html\&usg=ALkJrhj1WJBzwyp-

5VVUNDHaGPcZXVm hQ>. Acesso em: 06 jul. 2011.

., Disponível em: $<$ http://www.wma.net/en/20activities/20humanrights/40torture/>.

Acesso em: 12 jul. 2011.

., Disponível em: <http://www.wma.net/en/30publications/10policies/c16/>. Acesso em: 29 jan. 2012.

., Disponível em: <http:/wwww.wma.net/en/20activities/10ethics/10helsinki/>. Acesso em: 08 fev. 2012.

., Disponível em: $<$ http://www.wma.net/en/20activities/10ethics/20tokyo/>. Acesso em: 08 fev. 2012.

SITE BBC News UK. Disponível em: < http://news.bbc.co.uk/2/hi/americas/6185442.stm>. Acesso em: 30 jun. 2011.

SITE da Câmara dos Deputados. Disponível em: $<$ http://www.camara.gov.br/sileg/integras/439581.pdf $>$. Acesso em: 28 jun. 2010.

Disponível

em:

$\langle$ http://www.camara.gov.br/proposicoesWeb/fichadetramitacao? idProposicao $=343615>$.

Acesso em: 20 jun. 2011.

SITE Democracy Now. Disponível em: $<$ http://www.democracynow.org/blog/2011/4/6/one guantanamo trial that will be held in_new york $>$. Acesso em: 17 jul. 2011.

SITE do $O$ Estado de São Paulo Disponível em: $<$ http://www.estadao.com.br/noticias/internacional,guantanamo-afeta-reeleicao-de-obamadizem-analistas, 710832,0.htm>. Acesso em: 29 jan. 2012.

. Disponível em: <http://www.estadao.com.br/noticias/internacional,insetos-eramusados-durante-torturas-em-guantanamo,356331,0.htm>. Acesso em: 08 fev. 2012.

SITE Folha de S.Paulo. Disponível em: $<$ http://www1.folha.uol.com.br/folha/mundo/ult94u535354.shtml $>$. Acesso em: 22 jan. 2012.

., Disponível em: <http://www1.folha.uol.com.br/mundo/837862-veja-comofunciona-o-wikileaks.shtml>. Acesso em: 22 jan. 2012.

SITE Global Security. Disponível em: $<$ http://www.globalsecurity.org/wmd/world/japan/bw.htm $>$. Acesso em: 30 jun. 2011. 
SITE da Harvard Law School Library. Disponível em: $<$ http://nuremberg.law.harvard.edu/php/docs_swi.php?DI=1\&text=medical $>$. Acesso em: 12 jan. 2012.

SITE do jornalista Andy Worthington. Disponível em:

$<$ http://www.andyworthington.co.uk/2011/05/19/high-value-detainee-abu-zubaydahblinded-by-the-bush-administration/> . Acesso em: 22 jan. 2012.

. Disponível em: $<$ http://www.andyworthington.co.uk/2011/04/28/study-saysdoctors-at-guantanamo-neglected-or-concealed-evidence-of-torture-plus-my-interviewwith-press-tv/>. Acesso em: 22 jan. 2012.

SITE do Museu do Holocausto dos Estados Unidos. Disponível em: $<$ http://www.auschwitz.dk/doctors.htm> . Acesso em: 21 jun. 2011.

SITE do New York Times. Disponível em: $<$ http://www.nytimes.com/2009/04/07/world/07detain.html $>$. Acesso em: 21 jan. 2012.

SITE de notícias $I G$. Disponível em:

$<$ http://ultimosegundo.ig.com.br/brasil/justica+suspende+liminar+e+libera+pratica+de+ort otanasia/n1237851033103.html>. Acesso em: 13 dez. 2011.

SITE de notícias TPR. Disponível em: $<$ http://pubrecord.org/torture/3920/panetta-reporttorture-old-story/>. Acesso em: 21 jan. 2012.

SITE de notícias The Guardian. Disponível em: $<$ http://www.guardian.co.uk/world/2011/nov/03/israeli-doctors-report-torture-palestinian>. Acesso em: 23 jan. 2012.

SITE da ONU - Brasil. Disponível em: < http://www.onu-brasil.org.br/conheca hist.php $>$. Acesso em: 28 jun. 2010.

SITE da ONU. Disponível em: <http://www.un.org/documents/ga/res/39/a39r046.htm>. Acesso em: 12 jul. 2011.

SITE da organização Médicos sem fronteiras. Libya: Detainee tortured and denied medical care - MSF suspends work in detention centers in Misrata. Disponível em:

$<$ http://www.doctorswithoutborders.org/press/release.cfm?id=5744\&cat=press-release $>$. Acesso em: 27 jan. 2012.

SITE do Physicians for Human Rights. New York Court refuses to look at psychologist's role at Guantanamo. Disponível em: $<$ http://physiciansforhumanrights.org/blog/new-yorkcourt-refusal.html>. Acesso em: 27 jan. 2012.

. MA and NY Legislation to sanction health professionals who torture. Disponível em: $<$ http://physiciansforhumanrights.org/issues/torture/us-torture/ma-and-ny-anti-torturelegislation.html $>$. Acesso em: 27 jan. 2012. 
. Dual loyalties in US Immigration Detention. Disponível em:

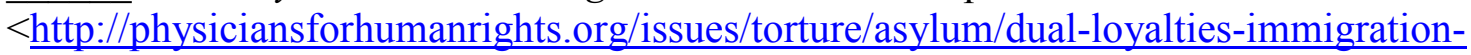
detention.html >. Acesso em: 27 jan. 2012.

Document Torture Internationally. Disponível em:

$<$ https://sites.google.com/a/physiciansforhumanrights.org/model-curriculum-on-theeffective-medical-documentation-of-torture-and-ill-treatment/model-curriculum-on-theeffective-medical-documentation-of-torture-and-ill-treatment> . Acesso em: 27 jan. 2012.

SITE da revista Galileu. Disponível em:

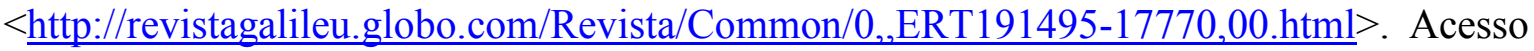
em: 22 jan. 2012.

SITE da revista Time. Disponível em: $<$ http://www.time.com/time/nation/article/0,8599,1207633,00.html $>$. Acesso em: 14 jul. 2011.

SITE Science Daily. "Could a new UN resolution end doctor's participation in torture", British Medical Journal, 25 February 2010. Disponível em:

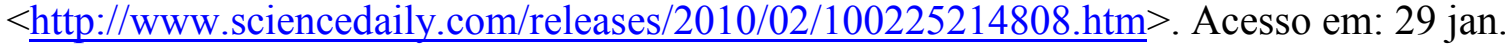
2012.

. LEPORA, C.; MILLUM, J., "The tortured patient: a medical dilemma", Hastings Center Report, v. 41, n. 3, 9 May 2011. Disponível em: $<$ http://www.sciencedaily.com/releases/2011/05/110509151248.htm>. Acesso em: 29 jan. 2012.

SITE do TPI. Disponível em: $<\underline{\text { http: } / / \text { www.icc- }}$ cpi.int $/$ menus $/$ icc/about $\% 20$ the $\% 20$ court $/$ icc $\% 20$ at $\% 20 \mathrm{a} \% 20$ glance $/$ icc $\% 20$ at $\% 20 \mathrm{a} \% 20 \mathrm{gla}$ nce?lan=en-GB $>$. Acesso em: 28 jun. 2010.

Disponível em: $\quad<\underline{\text { http://www.icc- }}$ cpi.int/Menus/ICC/About+the+Court/Frequently+asked+Questions/>. Acesso em: 28 jun. 2010.

Disponível em: $\quad<$ http://www.icc-

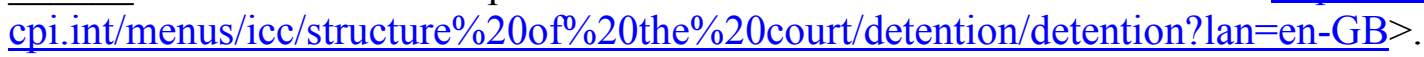
Acesso em: 28 jun. 2010.

Disponível em: $\quad \underline{\text { http: } / / w w w . i c c-}$ cpi.int $/$ menus $/$ icc/structure $\% 20$ of $\% 20$ the $\% 20$ court $/$ detention $/$ detention?lan=en-GB $>$. Acesso em: 28 jun. 2010.

Disponível

em: $<$ http://www.icc$\overline{\text { cpi.int/Menus/ICC/Situations }+ \text { and }+ \text { Cases/Situations/Situation }+\mathrm{ICC}+0104 / \text { Related }+\mathrm{Cases} / \mathrm{I}}$

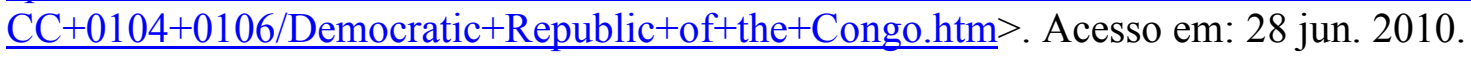

Disponível em: $<\underline{\text { http://www.icc- }}$ cpi.int $/$ menus/icc/situations $\% 20$ and $\% 20$ cases/situations/situation $\% 20 \mathrm{icc} \% 200205 / \mathrm{related}$ \%20cases/icc02050109/icc02050109?lan=en-GB >. Acesso em: 28 jun. 2010. 
$\overline{\text { cpi.int/Menus/ASP/Press }+ \text { Releases/Press }+ \text { Releases }+2011 / \text { Grenada }+ \text { becomes }+ \text { the }+115 \text { th }+ \text { S }}$

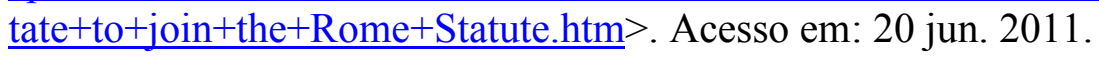

. Disponível em: $<\underline{\mathrm{http}}: / /$ www.icc-cpi.int/Menus/ICC/About + the+Court/>. Acesso em: 08 fev. 2012.

SITE do The Center for Justice \& Accountability. Bringing human rights abusers to justice - CJA. Case John Leso. Disponível em: <http://cja.org/article.php?list=type\&type=412>. Acesso em: 27 jan. 2012.

SITE Wikisource: Von Peter Hagenbach. Disponível em: $<$ http://de.wikipedia.org/wiki/Peter_von_Hagenbach>. Acesso em: 28 jun. 2010.

SITE WikiLeaks. The Guantanamo files. Disponível em: $<$ http://wikileaks.ch/gitmo/prisoner/10016.html>. Acesso em: 22 jan. 2012.

The Guantanamo files. Disponível em:

$\overline{<\mathrm{http}: / / w i k i l e a k s . c h / g i t m o / p r i s o n e r / 63 . h t m l}>$. Acesso em: 22 jan. 2012.

The Guantanamo files. Disponível em:

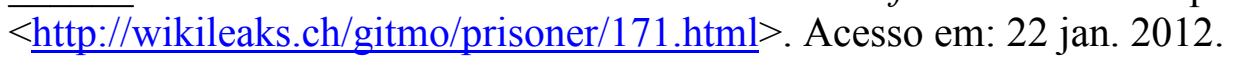

The Guantanamo files. Disponível em:

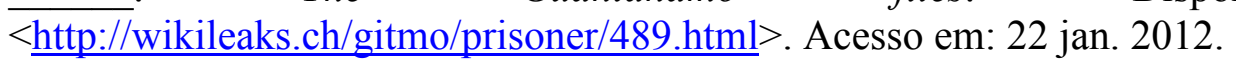

SOMERVILLE, A.; REYES, H.; PEEL, M., "Doctors and Torture", In: The medical documentation of torture, Edited by Michael Peel and Vicent Iacopino, New York, Cambridge University Press, 2009.

STOLZ, C.; GEHLEN, G.; BONAMIGO, E.L.; BORTOLUZZI, M.C., "Manifestação das vontades antecipadas do paciente como fator inibidor da distanásia", Revista Bioética, CFM, v. 19, n. 3, 2011. Disponível em: $<$ http://revistabioetica.cfm.org.br/index.php/revista_bioetica/issue/view/40 $>$. Acesso em: 25 jan. 2012.

THE PUBLIC Committee against Torture in Israel, Physicians for Human Rights - Israel. Doctoring the Evidence, Abandoning the victim - The involvement of medical professionals in torture and ill treatment in Israel. Periodic Report: October 2011. Disponível em: $<$ http://pt.scribd.com/doc/71825215/Doctoring-the-Evidence-Abandoningthe-Victim-The-Involvement-of-Medical-Professionals-in-Torture-and-Ill-Treatment-inIsrael>. Acesso em: 23 jan. 2012.

WEINDLING, P.J., Nazi Medicine and the Nuremberg Trials: from medical war crimes to informed consent, New York, Palgrave Mcmillan, 2004.

WELSH, J., "The problem of Torture", In: The medical documentation of torture, Edited by Michael Peel and Vicent Iacopino, New York, Cambridge University Press, 2009. 